

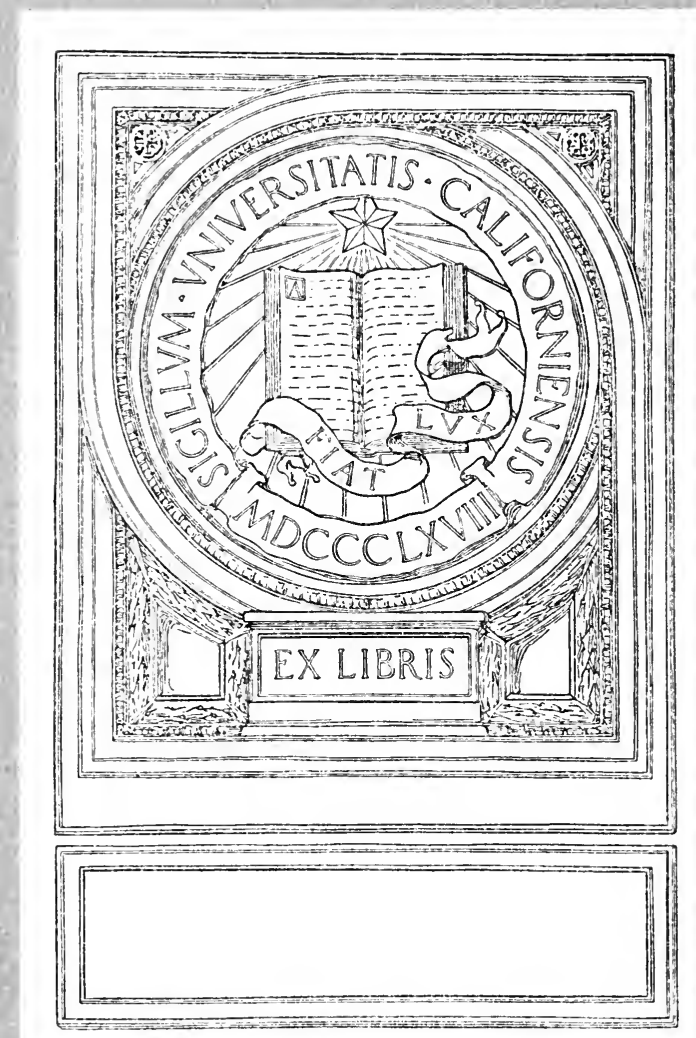





\section{Digitized by the Internet Archive in 2007 with funding from Microsoft Corporation}





\section{INSURANCE AND}

\section{CR I ME}

A CONSIDERATION OF THE EFFECTS UPON SOCIETY OF THE ABUSES OF INSURANCE TOGETHER WITH CERT AIN HISTORICAL INSTANCES OF SUCH ABUSES

\section{BY \\ AleXander Colin Campbell}

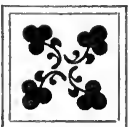

G. P. PUTNAM'S SONS NEW YORK AND LONDON

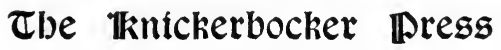




$$
\begin{array}{r}
1498141 \\
. C^{2}
\end{array}
$$

\section{GENERAL}

COPYRIGHT, IgO2

BY

A. C. CAMPBELL

Published October, 1902 


\section{TO MY FATHER}

WHOSE LIFE HAS BEEN USEFULLY DEVOTED TO THE ADVOCACY OF SOUND INSURANCE 



\section{PREFACE}

IN attempting a discussion of insurance as a producer of morbid conditions in society, I enter upon a field that, so far as I know, has never been explored in its length and breadth before. While highways, inventions, finance, and many other phases of activity in modern life are dealt with by those who trace their effects, good or evil, upon society, insurance thus regarded has attracted the attention of exceedingly few writers. Yet it must be obvious to anyone who will give the matter a moment's thought that our modern world is a vastly different world from what it would have been without insurance. When we find an influence helping to mould the world in which we live, it seems well worth while to consider in what way that influence works.

Nobody having, so far as my knowledge goes, preceded me in this field, I am obliged to make a first-hand study, to collect and sift such material as is within my reach, and to rely upon my own judgment for my conclusions, unguided and unwarned by the work of others. If I am, then, as I believe, an explorer in a new field, I shall not be accused of presumption if I claim the explorer's privileges as well as undergo his labours. The explorer is not expected to do the work of the topographer, to note every small detail and give distances and directions with mathematical exactness. His report covers the general features of the territory, together with such minor facts as strike him as noteworthy. Perseverance and candour are about the only virtues he is expected to exercise; and his report is accepted for what it may be worth, until the surveyor can follow him to 
correct where he has mis-seen or misunderstood, and to verify where his report is accurate.

I trust I shall not be found exercising the privilege sometimes presumed upon by explorers, of making up from hearsay or imagination elements of interest that do not appear in my notes. In these days, even the explorer who is tempted to excite the wonder rather than inform the minds of his readers has protection against his besetting sin in the intelligence of the public. It is useless for the man who, to-day, penetrates the frozen Antarctic or traverses the blazing plains of Arabia Deserta to tell us of griffins or rocs, of fountains of youth or philosopher's stones. We know better. I seek for myself, in my work, the same protection of public intelligence. Though neglected by sociologists, the subject treated in this book is by no means a recondite one. The results of insurance are participated in by everybody; and those results, if not the principles through whose operation they are brought about, or the historical development of the system in which they are embodied, are generally understood. In attempting to trace the early history of insurance, it is true, I venture upon ground which is not well surveyed; but the modern instances of which the bulk of the book is made up can be verified, in a general way, by those who watch the progress of events as mirrored in magazines and newspapers. As to the conclusions reached, if they do not commend themselves to plain people, that fact, I am ready to admit, will be one of the strongest arguments that could be brought against them. I attempt no fairy tales, and I trust that my work will be found at least accurate.

Those who seek here a compendium of the facts upon the subject treated will be disappointed. There are masses of ma: terial utterly beyond my reach. It is embalmed in languages I do not understand and cased in rare books which only extensive travel would enable one to find and years of patient labour to master. But insurance, as it happens, is, above all, 
an institution of English-speaking countries. Unfortunately for the English-speaking world, but fortunately for me in making this study, the devilry attending insurance among people of our language has been as varied, as shocking, and as demoralising as anything of the kind that is likely to be known among others. Even of the facts on record in English, I give but a tithe of a tithe of what might be given. But, though the instances here collected are few and closely summarised, they serve, at least, for illustration. If the main points I seek to make are worth making, and if further facts to illustrate and enforce them are necessary, more elaborate treatises will be written to bring those facts before the public;-and, if the points are not worth making, or if they are here sufficiently illustrated, it is well that the time and effort necessary for the collection and arrangement of additional instances should not be wasted.

The writing of a book like this may give those who read mainly by scanning titles and chapter-headings the impression that the object of the writer is to decry insurance and to bring the system and those who practise it into disrepute. That history warns us of danger in the practice of insurance I heartily believe; in fact, it is for the purpose of winning others to that belief that this book is written. But it is one thing to say that a thing has brought evil results, and quite another thing to say that the thing itself is evil. Even religion has, at times, been so perverted as to cause slavery, war, and all the round of villainies and miseries. The pointing out of errors and shortcomings, while not likely to win one popularity, is, nevertheless, necessary; and the more important the institution, the more uncompromising must be the critic who seeks to prevent the abuse of it. One could hardly study the nature and history of insurance without seeing that it is an invaluable element in social life. If my criticism is destructive rather than constructive, the fault is in my power of expression and not in my opinions. 
The very fact that insurance is, like the air we breatheomnipresent and unnoticed, yet necessary-makes it all the more important that any source of taint in it should be utterly removed. This is not a question, as some may think it, for the rich alone. Even a casual glance over the facts presented in the succeeding chapters will prove beyond question that those who are most deeply interested are the poor, the weak, the unprotected. Insurance affects not alone those who are parties to the insurance contract. For these, it is usually all beneficence. But for others, who, it may be, not only are not parties to it, but do not even know of the existence of the contract, insurance may be an agency of torture or destruction whose effects are exceeded only by plague, famine, and war.

I believe that the first, and, in many cases, the only thing necessary, in order to improve an institution or ameliorate unjust social conditions, is to make the facts known to that greatest of philosophers and statesmen, the common people. "Everybody," said good old Abraham Lincoln, " thinks better than anybody." As the subject I deal with is a matter of interest to " the man in the street," and as the common sense of that man is the best guide of reform, I seek to appeal to him. For that reason, I avoid, as well as I can, technical discussion and all that may necessarily involve it. I avoid also, wherever possible, the statistical phase of questions, for the double reason that figures are likely to repel the reader and that they are almost sure to mislead the writer. Where necessary facts can be expressed only in figures, I do not hesitate to use that form of expression. The methods of the professional statistician have never so commended themselves to my taste or judgment as to arouse me to emulation. The statistical argument is seen at its best when used by a professional to convince a professional. Such is not my position or aim. I do not appeal to the professional sociologist or the professional insurance man. I seek to awaken the interest of the common people in a sub- 


\section{Preface}

ject which seems to me of vital importance to the common people in these modern days, and, through that interest, to bring about changes which shall prevent the recurrence of the abuses of the past and correct the abuses of the present.

June 20, I902. 



\section{CONTENTS}

\section{CHAPTER I}

THE NATURE OF INSURANCE

The Insurance Contract in its Relation to Crime-Indemnity the ObPAGE ject, but Contingency the Prime Element-Confusion of Interests -Danger of Abuse - Heinousness of Insurance Crimes - The Public its Own Protector . . . . . . . . I

\section{CHAPTER II}

THE HISTORY OF INSURANCE, GENERALIY

Antiquity of the Practice-Varying Methods to Meet Social NeedsEffect of Usury Laws-Insurance a Combination of Inventions -Brief History of its Main Branches . . . . . .

CHAPTER III

MARINE INSURANCE

Nature of this Business-Its Technical Character-Special Dangers of Abuse-Effects of Abuses upon those in the Trade, and upon the Public-The Facts as Seen and Used by Creative Writers

CHAPTER IV

\section{MARINE INSURANCE-Continued}

Fraud Coeval with the System-Early Ordinances Designed to Check Abuses - Experience of Medieval Maritime Cities - State of the Law in England - Case of "the Noted Captain Codling " - $\mathrm{PO}$ sition of the Underwriters in Relation to the Reform of the Law, 56

\section{CHAPTER V}

MARINE INSURANCE-Continued

The Amendment of the British Merchant Shipping Laws a Subject of Keen Controversy - Large Number of Vessels "Missing" Attracts Attention-Loss of Life in "Missing" Vessels-What was Said by Apologists for the System-Evidence to Show that Care in Shipbuilding and Navigation Make for Safety $\quad$. $\quad$ - 74 


\section{CHAPTER VI}

MARINE INSURANCE-Concluded

The British Agitation for Security of Life at Sea-Plimsoll, his CharPAGE acter and Work - Difficulties of the Situation and Excuses of those Interested - Amendments of the Law, Following Report of Royal Commission - The Plimsoll Load-line-The Commission of r884, its Good Proposals not Implemented Owing to Political Upheaval-Does the Slaughter of Sailors still Continue?

\section{CHAPTER VII}

\section{FIRE INSURA NCE}

Its Nature and the Nature of the Abuses to which it is LiableSome Account of its History-The Position of the Agent . . I2I

\section{CHAPTER VIII \\ FIRE INSURANCE-Continued}

Some Instances of the Abuses that have Existed - Statistics and the Statistical Argument-Actual Fire Loss and how it is Affected by Insurance-Firebugs and their Methods-The Effects of Fire Insurance Abuses in Great Britain

\section{CHAPTER IX}

FIRE INSURANCE-Concluded

The Need of Reform - Demoralisation caused by Abuses of the System - Ignorance of the Subject on the part of those who Make and Interpret Laws - Public Sentiment can Directly Cause Improvement

\section{CHAPTER $X$}

\section{LIFE INSURANCE}

Nature of the System - Its Growth in Recent Times - Importance and Adaptability-How Abuses Arise-Supreme Importance of Maintaining a Pure Life-Insurance System .

\section{CHAPTER XI}

\section{IIFE INSURANCE-Continued}

Some Early Abuses-Tontines- "Little Goes "-Gambling in Lives -Repressive Legislation and its Results-Alliance of Insurance and the Lottery-Essential Soundness of the System-Its Persistence and Growth 


\section{CHAPTER XII}

LIFE INSURANCE-Continued

Murders for Insurance Money - One of the Dangers of Modern SoPAGE ciety - The Maybrick Case and Reasons for not Instancing itThe Strange Case of Thomas Griffiths Wainewright-His Elaborate and Horrible Crimes-The Insurance Companies to Blame for his Career

\section{CHAPTER XIII}

\section{LIFE INSURANCE-Continued}

Instances in Recent Years of Murder for Insurance Money - The Viau-Parslow Case - Horrible Fate of a Trusting Husband Murder of a Young Woman by her Business Partner-Holmes and his Fearful Record - The Most Elaborate and Fantastic

CHAPTER XIV

\section{LIFE INSURANCE-CHILDREN}

Covering the Lives of Children-Social Conditions which Gave Rise to the System in Great Britain-Early Suspicion of Child-Murder for Insurance Money-Investigation by Parliament . 259

CHAPTER XV

LIFE INSURANCE-CHILDREN-Concluded

Changes in the Burial Clubs - "Collecting" Societies and their Methods-The Royal Commission of r87o-Society for the Prevention of Cruelty to Children-Efforts Made to Regulate the Business and Difficulties in the Way-Practical Results . . 275

\section{CHAPTER XVI}

\section{COMPANY FRAUDS}

Evils Arising from Desire of the Trustee to Possess the Insurance Fund-Promoting Bubble Companies-The Case of the West Middlesex-Daring and Skill of the Promoters-Exposure and Ruin of the Company-Bogus Companies a Constant Drain upon the Public

\section{CHAPTER XVII}

\section{COMPANY FRAUDS-Continued}

"Graveyard " Business-Experience of Pennsylvania-How the System Arose-Its Terrible Effects-The Bubble Pricked-Danger of Neglecting the Law of "Insurable Interest" . 


\section{CHAPTER XVIII}

\section{COMPANY FRAUDS-Concluded}

The Assessment Endowment Craze in Massachusetts-Defect in the Law and what it Led to-Wild-cat Schemes Rob and Demoralise a Community-Many of the Working Poor among the VictimsInvestigation and what it Revealed-Responsibility of the Legislature and of the People

\section{CHAPTER XIX}

\section{CONCIUSION-APPLICATION}

Summary of what has been Shown-What the Facts Mean-Dangers in the Future as well as in the Past-" What are You Going to Do About It? "-Benefits and Dangers of Statute Laws-Benefits, without Danger of Enlightened Public Opinion-What are You Going to Do About It? . . . . . . . . 378

\section{Appendix}

Index 
INSURANCE AND CRIME 



\title{
INSURANCE AND CRIME
}

\author{
CHAPTER I \\ THE NATURE OF INSURANCE
}

The Insurance Contract in its Relation to Crime - Indemnity the Object, but Contingency the Prime Element-Confusion of Interests Danger of Abuse - Heinousness of Insurance Crimes - The Public its Own Protector.

JUS'T as everybody eats bread without knowing its chemical $\checkmark$ composition, so everybody uses insurance without understanding its nature. Insurance is a guarantee of indemnity; its object is to replace money or other property, actual or prospective, that is lost. Insurance is not designed to avert disaster; it is not designed to afford a profit. If either of these features is added to the contract, as is often done, it makes more than an insurance contract of it, and adds to the necessity, which is strong enough in any case, of providing checks and safeguards against abuse. The theory of the system by which the principle of insurance is provided is this: Many people who are subject to a common danger of financial loss agree to pool their expected losses by providing in advance, by general contribution, a fund from which those who actually suffer loss may be indemnified. That is, each party to the arrangement pockets a small, immediate, certain loss in order to be indemnified for a great, future, contingent loss. Any arrangement that the parties may make, or that may be made 
for them, say with a banker or so-called insurance company, to provide the money or any part of it, or to receive the contributions, "care for them, and pay out sums for losses in accordance with the contract, or for expenses of administration, is not a violation of the co-operative principle involved, but only introduces another co-operator. This is true of our modern life generally and is in accordance with the historical development of trades. For instance, in rural localities, there exist at this day what are known as "beef clubs." The members of a beef club in rotation provide beeves as required, the animals are killed, and the meat divided among the members of the club. As business grows and the locality develops industrially, the local butcher takes the place of the club. The effect is the same, however, except that, besides those who supply the animals and those who consume the meat, the butcher comes into the circle and does for all concerned the work formerly done by the people themselves directly or through a committee. The addition of the meat dealer to the circle does not alter the fact that animals are grown and killed and their flesh divided and eaten. So an insurance company, in carrying on its operations, merely specialises the work of distribution, but does not alter the fact that the contributions of many are combined into a fund and that fund divided amongst those of the contributors who suffer loss from some specified cause.

Neither does the fact of one person paying the contribution and another person who, nominally, does not contribute, receiving the amount of the insurance, affect the case. For instance, a man, out of his own earnings, insures his life, but his widow and orphaned children receive the insurance after he dies. The transaction is of the same nature as though the father had put money in the savings-bank in the child's name, the child drawing the money after the father's death. In that case, the money is a gift; and, from the bank's point of view, the money is deposited, not by the father but by the child. So, 
for the purposes of this argument, the real contributors of lifeinsurance funds are the prospective widows and orphans who are to be the beneficiaries of those funds.

It is necessary to explain these points clearly, because they have been and are apt to be very generally misunderstood or forgotten. If the reader who does me the honour to follow me further will accept wholly the dogma that insurance is always loss, that it can never be anything else, he will be able to trace more clearly the thread of similarity running through the happenings which are summarised in the succeeding chapters.

The work of the insurance company is not to prevent loss, any more than the work of the physician is to clear away dirt and so prevent fevers. If disease were prevented, the physician would be unnecessary; and if loss could be averted the insurance company would have nothing to do but wind up its affairs. The fact that doctors are generally most active in public sanitation movements does not lessen the force of this truth; nor does the fact that insurance companies often maintain salvage corps and wrecking crews alter the fact that the purpose of insurance is not to guard against loss, but to distribute loss. The insured person who makes a profit out of his insurance, or who fails to suffer loss by it, is in the same position as the man who takes more money out of the bank than he put in. If a man insures his house for exactly what it is worth, say two thousand dollars, and pays therefor twenty dollars, and the house is destroyed, he receives two thousand dollars. Thus, it will be said, he is in exactly as good a position, financially, as he was before. But that is not quite true, for he has lost twenty dollars. In this respect, however, he is in exactly the same position as every other man insured for a like amount on equally valuable property and at the same rate-each of them has lost exactly twenty dollars, and each has two thousand dollars less twenty. The fact that one man has two thousand dollars' worth of cash and the others each have two 
thousand dollars' worth of house does not affect the comparison. Not a man among them has gained anything, and not a man among them but has lost twenty dollars.

This proposition that insurance is always loss and nothing else is the pons asinorum of the whole system. The failure to keep this in mind has misled some high authorities on the subject, and has been the cause of starting many a scheme which, however honest its promoters, was foredoomed to disaster. But, however simple the foundation idea of insurance may be, it soon runs into confusing mazes of finance. This we need hardly wonder at, for we see the same in other things. The keeping of accounts is based on the simple theory of noting on one side of a book all that is received and, on the other, all that is given out. Yet, when the entries become many and represent complex transactions, we find that even the ablest accountants differ as to whether figures, representing, it may be, large fortunes, should be entered on one side or on the other; and a really skilful man can "cook" accounts so that even the Father of Lies himself might be proud to claim the work as his own.

Let us consider, for a few moments, the nature of the insurance contract in relation to crime and wrong-doing. It will be my duty, in the following pages, to set forth many forms of evil arising from insurance. In the insurance contract, as I believe, we can see the suggestion of nearly all of them. I venture to assert that of all the various kinds of transactions that go to make up modern commerce there is not one that involves such danger to the individual and to the community as insurance. The danger of abuse arises from the very nature of the thing itself. I hope to be able to establish to the satisfaction of my readers that of which I am perfectly convincedthat there is no phase of modern business life that should be so universally understood or so vigilantly watched as this.

In the first place, insurance has in it an element of indefinite- 
ness not to be found in other lines of business, and this opens the way to fraud. If $\mathrm{A}$ buys a hat from $\mathrm{B}$ for a dollar, and goods and money change hands over the counter, the transaction is a simple and definite one, and there is a minimum of chance for fraud on either hand. It is true, the hat may not be as good as represented, or the money may be counterfeit; but each is open to inspection by the party most interested in knowing the facts, and any differences can be settled at once. But if there is delay in delivery, or if the parties, instead of dealing face to face, are represented by agents, or if the delivery of cash or goods is made contingent upon some uncertain event, - if one or more of a hundred possible complications are introduced, the opportunities for fraud are greatly increased. Yet, in any case, this remains a transaction between two individuals, and self-interest and a man's natural abhorrence of defrauding one whom he knows as an individual join to protect the interests of the individuals concerned, Besides, transactions between individuals are relatively small, and there is comparatively little temptation to fraud.

But how different is the transaction in the case of insurance! Each individual deals not with another individual, and face to face, but indirectly and with a great many of whose existence he knows practically nothing. He receives for his money not goods, but a document guaranteeing him indemnity in case of a loss which will probably not occur within the time for which the money is paid. If the contingency insured against-fire, shipwreck, or whatever it may be-does not arise, the transaction is ended. But if the contingency does arise, the whole amount insured for must be paid to the sufferer. Pending the arising of the contingency, it is impossible to name the person or persons to whom the fund in justice belongs. It is clearly not the property of the insurance company or other corporation or person in whose charge it is. Nor can the portions contributed be said to belong to those who have severally handed them in. 
The fund is the property of a person to be chosen by accident. As a legal document, it is true, the contract is as clear and definite as any contract based upon a contingency could be. But, from the personal point of view, nothing could well be more indefinite. It is true, also, that the intervention of an insurance company, not as custodian of the funds merely, but as guarantor, introduces an element which simplifies the question of ownership. Still, with self-interest for an advocate, even a second-class casuist can convince himself that in stealing that money he is robbing nobody; and he would be a very touchy person indeed who should feel, if that money were stolen, that he had been as clearly robbed as though his pocket had been picked. In a world like ours, in which the vast majority use all their energy and all their wit to make money, a fund like this, with-arguably-only contingent owners, is a constant temptation. This is the centre of the disturbance, but from that centre run many ramifications.

There are two people particularly tempted to misappropriate this fund. The first is the custodian of it, and the other is the contributor to it and contingent beneficiary of it. From the misdoings of these two, who embody the great insurance interest of the world, arise nearly all the evils incident to the abuse of insurance.

There is a flavour of deviltry about insurance frauds that is peculiar, whether they are committed by insurer or insured.

If the insurance fund is appropriated by the person in whose charge it is-the insurer, as he is called-the crime is far worse than an ordinary embezzlement or defalcation. For this fund is not only a trust fund, but a trust fund of a peculiarly sacred character. It is contributed, as a rule, by the best people in the community under the influence of the highest motives; by the father, who denies himself in order that he may provide for those dependent upon him when death shall put a stop to work and wages; by the business man, who seeks to protect his own 
name and the interest of his creditors in case of disaster which he cannot otherwise provide against; by the employee, who has too much self-respect to ask his friends, as a matter of favour, to guarantee his faithfulness; in short, by those who possess those sturdy virtues of independence, frugality, and forethought which are the very backbone of our economic system, virtues which are to be commended everywhere, except when paraded as a substitute for virtues still higher and more beautiful. To wreck an insurance company is to rob this class of people and those who have trusted them; and to rob such a class under such circumstances is to make men's virtues the means of their destruction; it is to condemn the good, because of their goodness, to punishment worse than that meted out to the vile. When a burglar breaks into a house, and, being interrupted in his thievery, shoots the person who challenges him, we regard the crime as atrocious. But at least the burglar shows some sort of virtue by his brute courage in making violent entry, knowing that the discovery of his presence is, of itself, his condemnation. But if he came in the guise of a belated traveller, begged and received food and shelter, and took advantage of the kindness shown him to rob and murder his benefactor without danger to himself, his crime would be as much worse than the other as that other is worse than no crime at all. The churl who, deaf to the plea of hospitality, turns the would-be robber away, saves his life and his property, while the man of kindly and hospitable nature opens the way to his own destruction. In the same way, when an insurance company is wrecked, the selfish or thoughtless man who refuses or neglects to insure is left unscathed, while he who performs a manifest duty, though at some sacrifice of present means, is made to suffer through the very goodness of his act.

In one case-that of life insurance-a robbery by the trustee is far worse than horse-thieving in a prairie country, where to deprive a man of his horse is not merely to disarrange all his 
plans and cause him far greater loss than the loss of the animal, but it may be to condemn him to a slow, solitary, fearful death. The man who, from his youth, has paid life-insurance premiums may, through accident, disease, or other cause, become uninsurable under a new policy. Moreover, he has come nearer to the time of his death, and his need of insurance, if not greater, is more urgent than ever. Yet he is denied it; and the contract upon which he depended and upon which he had a right to depend proves to be only a piece of waste paper. His effort of a lifetime to provide for wife and family proves futile, and the remnant of his life is embittered and death made a thousand times more terrible by the knowledge that those he loves must eat the scant and bitter crust of charity instead of partaking of the plenty that he had honestly bought for them.

If, on the other hand, the robbery of the insurance fund is committed by a contributor to it-usually known as the insured -the case is still worse, just as an atrocious, brutal crime with violence is worse than the skilful and conscienceless fraud, or as two crimes are worse than one. The insured can claim the benefit of the insurance fund only when he has shown not only that he has suffered loss, but that he has suffered that loss through the arising of the very contingency insured against. If he is guaranteed against loss through the wreck of his argosy to Mexico, he cannot establish his claim upon the fund by showing that he needs the money to lend to an acquaintance. The contingency insured against is almost invariably some event exceedingly undesirable in itself-the loss of a life, the wreck of a ship, the burning of a building, the defalcation of a trusted employee. (Now, if the insured can simulate this loss so as to convince the insurer that it has occurred, he can claim the insurance money, and so gain much while losing little. For instance, if goods in a certain building are insured against fire, and the building is actually burned down, the insurer may thereby be convinced that the goods have been destroyed, even 
though, in fact, they have been removed before the fire broke out. The best way, in many instances, to convince the insurer that loss has occurred through the disaster insured against is to have that disaster actually occur; and the way to defraud the rightful owners of the insurance fund by such means is to have no loss, or as little loss as possible, fall upon the insured by reason of that disaster. In such a case, not only is the robbery a crime, but the means taken to accomplish it is even a greater crime; and thus we see that insurance provokes the insured to evil in a twofold way.)

We shall see, as we proceed, that, in practice, it is by bringing about disaster through which innocent persons are likely to be the severest sufferers that the insured can best make good a fraudulent claim. Here we have a fearful vista of evil opened to our sight. And, as we go on with our investigation, we shall find that occurring which we might expect. We shall find that not merely has insurance provoked people to fraud, forgery, and misrepresentation, and to conspiracies to carry on all these, but it has made barratry a trade, arson a business, and murder a fine art; that it has given rise to whole systems and cycles of evil; that there is hardly a crime in the calendar of which it has not been the prolific mother and the assiduous and successful nurse.

But even this is not all. As frauds committed by the insurer are the worst possible frauds, so are the crimes committed by the insured the worst possible crimes. Some of these crimes have become notorious throughout the world, and the perpetrators of them have attained the topmost height of that bad eminence upon which the world pillories the memory of the worst criminals of our race. In these more brutal acts of villainy, the treachery which gives to frauds committed by insurance companies and their employees so bad a character is to be traced. They indicate, moreover, the poisoning of the most sacred relations that exist between members of society. In 
thousands of cases the employer has sent his workmen to death in order to make sordid gain through an insurance contract. In thousands of cases the master of a ship, the man to whom the crew looked for guidance through the dangers of the deep, has given over all or part of his crew to Davy Jones that an insurance fraud might fructify in gold for himself and his accomplices. The cup has been poisoned, again and again, by wife or child, so that the corpse of the husband or father might be presented to the insurance company as a voucher for the payment of money. Worse than that, if worse be possible, the golden bribe of insurance has caused the natural guardians of children to neglect their care; it has even caused the mother to smother the babe at her breast. There is no relation known in our social life too sacred to have been poisoned by insurance, and made the means of crimes so revolting that nothing but the hope of preventing, to some extent, their recurrence can so far overcome our horror and loathing as to enable us to contemplate them.

So far, we have been considering the influence of the abuses of insurance upon individuals directly. But there is also an influence upon society at large. If we consider it at all attentively, we shall see that peculiar demoralisation follows crimes thus arising. This, in one sense, is merely the accumulation of cases of disturbance of those individual relations which are the very framework of society. But the effect upon the mass is worthy of consideration by itself.

Anticipating in a general way what will be more specifically set forth in subsequent chapters, I may give a couple of imaginative instances to show what I would be at. Take, first, the frauds committed by the insurer. If some sharper has floated an attractive scheme which, while based more or less upon insurance principles, is, in fact, a gambling speculation, his success will cause others to follow his example and set up similar shops. At the same time, the multiplication of these 
gambling shops-for they are often nothing else-has a tendency to draw more and more people into the game. The direct money loss is great, but that caused indirectly, by distracting attention from honest labour, is far greater. But, worst of all, this sort of thing brings demoralisation upon the community the effects of which may last for generations. As to crimes of the insured, aside from the heinousness of the acts of individuals, the effect upon the community is of the worst possible kind. It is clear that only a proportion, and, in a general way, a small proportion, of money devoted to insurance can be taken by those who act in bad faith. Otherwise, those who act in good faith would keep clear of insurance, just as they do of what is known among the "fancy" as a "skin game" of any kind. But let us suppose that ten per cent. of the money paid in is taken by those who have no right to it. It is clear that only a very small proportion of this ten per cent. is paid in by those who receive it as indemnity for bogus losses; the bulk of it is contributed by those who act in good faith. If all acted in good faith, other things being equal, the contributions might be reduced by ten per cent. That is to say, the good people are made to pay not only for accidents to themselves, but for crimes committed by others. Let this be continued, and the advantage given to the bad people will increase the number of bad people, and the number and atrocity of their crimes. Of this we shall find abundant evidence when we come to consider the facts. The demoralisation which results from this constant temptation to evil threatens, at times, almost the very life of society. Crimes which are indirect in their action do not arouse the same horror and do not call forth the same hearty and unanimous condemnation as do even smaller crimes when the perpetrator and the victim come into direct and violent contact. We see this well illustrated in the case of a war brought about by a king for his own benefit, but involving the death of thousands of men. If the king were to 
murder one peasant for his land or his money, he would be execrated by all mankind; but, though his motives in making war are the same and the results a thousand times more disastrous, the world may tolerate or even applaud his act. But the very fact that the public conscience is not hurt by an act which is wrong in itself is the cause of demoralisation. Like the unpunished faithless wife of whom Tennyson's Arthur speaks, an unchecked sordid crime, such as an insurance fraud,

like a new disease, unknown to men, Creeps, no precaution used, among the crowd,

doing its deadly work and leaving the whole body social diseased and poisoned. Instances of this also will be found as we trace the historical relation between insurance and crime.

Even to-day, when it is universally used, and has become as much a part of commercial life as the post-office, insurance is comparatively little understood. It can easily be believed, then, that, in the past, when insurance was far less understood as a science and far less perfect as a system or art, the abuses to which it is liable existed in even more gross and glaring forms, and, probably, on the whole, were more demoralising than those of our time. One by one, these evils have shown themselves, and, being for the time unchecked, they have gone on increasing and extending, until the people could tolerate them no longer, when means have been devised to repress them more or less completely. Sometimes, these evils have been checked by some amendment of the statute law. In other cases, the very life of trade has made it necessary that the evil practices should be abandoned, and so a good custom, which has even greater force than statute law, has grown up and choked off the bad custom.

But the fact that evils have been killed or checked does not prove that there is no danger for the future. Every student of history knows that a popular delusion which has been com- 
pletely exposed in one generation may be unknown for a hundred years, and yet recrudesce and victimise whole communities. This is almost certain to be the result if those who seek to gain by deceiving their fellows can present the old delusion in new and gaudy guise. Every development of trade or society calls for its own particular application of the insurance idea; and this, in turn, gives rise to its own particular form of crime which must be guarded against.

In this work of guarding the interest of the people, the difficulties are greatly increased by the growing complexity of social life, that great intertwining of activities and interests which we call modern civilisation. This growing complexity, in the first place, increases the gains of successful fraud. In the second place, it makes it more and more easily possible for a clever rogue to work a system of cheatery under the mask of a beneficent financial operation. Also, it makes it more likely that some wrong-headed, even though honest, fool, may let loose among the people some wildcat scheme that will deceive others as well as himself, and in the end ruin all who come in touch with it. It is no part of my purpose in writing this book to set forth a true theory of insurance; let that be done by those who think they can keep their heads clear in the mazes which it is the business of such theorists to thread. But it will be possible, in succeeding chapters, to consider some of the delusions as well as the crimes of insurance; and, while this may serve us but little as showing the true system, it may impress us with the difficulty of the case and the absolute need of keeping constant, vigilant watch upon insurance operations.

As to what should be done in order to purify insurance and protect society, I hope to devote a few words to that branch of the question after placing before the reader such facts as I have mastered. Meantime, I have this to say-that the triumphs of modern science furnish abundant proof that even the greatest mysteries can be cleared up and the most puzzling problems 
solved, if we but observe the phenomena presented and study the laws which govern their occurrence. No matter how complex the operation of nature, no matter though, at first, it may seem but a contradiction of mysteries, we shall, by careful watching, by honest thinking, at length understand the main principles at work. This done, by operating on these main principles, we shall be able to control the working of the whole complex mechanism. What we need is a philosophy or science of insurance which can be understood by the common people, whose will makes the laws and whose habits make those social customs that are stronger than the laws. This will come with time and the labour of many. But, even before this, we must learn that there is something to be learned and something to be done. It is in the hope that it will be seen that a complete thread of principle runs through the facts on this subject already known to the world that I have collected here a few of those facts. The step is but a short one, it is true; but so that it be in the right direction, it will be found well worth taking. 


\section{CHAP'TER II}

\section{THE HISTORY OF INSURANCE GENERALIY}

Antiquity of the Practice - Varying Methods to Meet Social Needs Effect of Usury Laws - Insurance a Combination of Inventions Brief History of its Main Branches.

I $\mathrm{N}$ order that the historical facts of which the bulk of this book is made up may be the more clearly understood, it will be well to give here a synopsis of the history of insurance, keeping in mind that phase of the subject which we have now before us. Unfortunately, there is no book, so far as I know, from which one can draw the facts for such a summary as I propose. In fact, the history of insurance is yet to be written. There are many books on this subject, as there are on almost every other, but those that I have had the opportunity to consult are partial or superficial, or both. The facts for the summary here attempted are taken from so many sources that it would be tedious to give references.

Insurance, as has already been clearly indicated, has to do with wealth, with property. The growth of insurance, therefore, depends upon the increase of wealth. On the other hand, by giving security to industry in protecting the worker from loss through unforeseen disasters, it facilitates and promotes the growth of wealth. As the pioneers of a new country depend upon the main body of settlers, yet open the way for advancing settlement, so insurance both promotes and is promoted by industry. It is a favourite conceit with insurance men to speak of their business as "the handmaid of commerce." Considering the facts, this is too modest a metaphor; for insurance 
bears to commerce the relation of body-guard rather than of mere servile attendant.

We are apt to think of insurance as a system which existed as one in that distant and indefinite time that we speak of as " the past," and which has been divided and specialised, like other activities, with the development of commerce. I do not say that this is not the case, in one sense; but I do say that such an explanation does not convey the whole truth in relation to the history of this institution. From my point of view, it would be more accurate to say that each branch of insurance, as we have it to-day, is a separate growth which sprang up naturally as the need was felt for that particular form of protection. The recognition of the common principle involved, and the means of applying that principle readily, and, in a sense, scientifically, to new requirements, are the modern features of the business. We think of our modern system of insurance as a marvel of variety and adaptability. But, as a matter of fact, there are forms of insurance that have arisen from special requirements, have flourished while those requirements continued, and have died out when changes in society made them no longer necessary - and some of which were never called by the name of insurance at all.

Some writers on the subject tell us that insurance had its origin in such and such a place at such and such a time. They might as well tell us that commerce began on a given day between Creation and the Deluge and give us the name of the inventor of it. When the rude savage first traded his stone scraper for a piece of mammoth tusk commerce had its birth. As soon as property began to accumulate, we may feel assured, insurance came into use. The applications of the idea are infinite. When Joseph received from the Egyptian husbandmen, in the years of plenty, contributions of their surplus to provide a sustentation fund against the years of famine whose oncoming was plain to his prophetic eye, he carried on probably the 
greatest insurance transaction known to history. The ancient Greeks and Romans applied the principle.so as to secure the safety of beleaguered garrisons or armies in distant fields, by guaranteeing against loss those shipowners who attempted to carry supplies to such garrisons or armies. The medieval cities, besides being many other things, were mutual insurance societies for the benefit of the citizens; so that one who was too old or too feeble to work might be assured of comfort; and so that any citizen suffering loss through fire or other disaster might have his loss made up to him, and so be in a position to carry on his trade. In the leases under which farming was carried on for hundreds of years in England, and, I believe, in other countries as well, the landlord guaranteed the tenant against loss in respect of certain portions of the work which were supposed to be especially risky, but, from the landlord's point of view, especially desirable. For instance, the landlord, under the leases which were common in England after the thinning-out of the population by the Black Death, insured the tenant against loss through murrain among his sheep. The constant danger to travellers of being captured and held for ransom led to one of the most curious applications of the insurance principle, to which a brief reference is made in the next chapter. And thus many, many instances might be cited of the use of the insurance idea to minimise the evils and avert the losses to which people were liable in the olden times. Those already given, however, will be enough to indicate that insurance as we have it to-day, like all other great institutions, is a vast combination of inventions, each made at first for a special purpose, but afterwards brought together in one great whole and directed to one end. In the main, that which has made insurance both necessary and possible is the extension of trade. And, on the other hand, without insurance, the vast fabric of modern commerce would melt away to the proportions of the traffic of a petty African patriarchate. 
The prime use of insurance being to protect trade, we might well expect to find amongst its earliest forms that which would distribute the losses on the first great highway of commerce, the sea. Marine insurance, in fact, may fairly be called the earliest system of insurance. The trade of Venice, Genoa, Barcelona, and other great maritime cities of medieval Europe could not have been built up, except behind the bulwarks of insurance. It is true that in that writing which represents nearly all that the average man knows of the matter, the reader is left to infer that no such thing as insurance had ever been beard of. I refer to Shakespeare's Merchant of Venice. The whole plot of that play turns upon the assumption that, Antonio's ships having been lost, Antonio himself has lost the whole value of ships and cargoes. In view of the proneness of those who write about him to represent Shakespeare as having had a master's knowledge of every trade, it seems like flying in the face of authority to say that, in this case, the Great Bard displayed ignorance. It might be said that Antonio must have done as some great modern shipowners do-insured himself; that is, charged each vessel an insurance premium, and so accumulated a credit from which losses could be paid. But in that case, of course, he would have banked the money, and so would have had it at need. The probability is that Shakespeare ignored the insurance idea in order to heighten the dramatic effect - a thing that, according to sound rules of criticism, such a master, working upon a masterpiece, would have a perfect right to do. If this is not the explanation, then we can only conclude that the great playwright was not the omniscient person his admirers would have us believe, and that he knew nothing about insurance. Yet, about forty years before Merchant of Venice was written, the Speech from the Throne at the opening of the first Parliament of Queen Elizabeth contained these words: "Doth not the wise merchant, in every adventure of danger, give part to have the rest assured ?" 
And, in I60I, three years, or thereabouts, after the play was first put on the boards, a statute was passed by the Parliament of England, in the preamble of which it was declared:

It hath been, time out of mind, an usage amongst merchants, both of this realm and of foreign nations, when they make any great adventure (specially into remote parts),

Antonio, it will be remembered, had argosies in Tripolis, the Indies, Mexico,- " "and other ventures he hath squandered abroad"

to give some consideration of money to other persons to have from them assurance made of their goods, merchandises, ships, and other things adventured, or some parts thereof."

It is plain that other Englishmen were aware of the great fact of insurance, even if their greatest poet was not. But we are not dependent upon English evidence alone to prove a knowledge of marine insurance on the part of the traders of the middle ages. In the fifteenth century, and probably earlier, the Italian cities had their own insurance laws. One of these that has been preserved to us is a decree of the Grand Council of Venice itself, in I468. But in I400, a work was written by one Uzzano, of Florence, in which mention is made of insurance effected between London and Florence. In fact, near the very Rialto of Venice was a street called, we are told, Insurance Street.

But long before marine insurance, so called, became known, the results of insurance were attained by what are known as: bottomry loans-loans on the security of ship or cargo. The lender, in such a case, could hardly expect repayment of his money, if the property pledged to him were swallowed up by the sea. Thus, it has always been the rule in bottomry loans that the loss of the ship or cargo on which the money has been loaned is as complete a discharge of the debt as the repayment of the money. Consequently, lenders have charged not only 
interest on their money, but also a premium to hold them harmless against the perils of the sea.

It is well to remind the reader, at this point, of the laws against usury, which were almost universal in the middle ages. We, in our day, accept interest as a fact, just as we accept the law of gravitation. But interest as an acknowledged element in trade is essentially a modern idea. The laws of Moses, of Mahomet, of Lycurgus, of almost every great lawgiver, prohibited usury. The rule of conduct laid down by Jesus was held by the Church of the middle ages to place this increase of money under the ban. Even Luther, when he rebelled against the authorities of the Church in his time, made this system of "money breeding money" the subject of scathing denunciations. But, while it is true that usury, including what we call interest, was, for centuries, denounced, it is equally true that interest, if not usury, has always existed. But, in medieval transactions, interest was "worked in" in many cases, like the suit of clothes which could not be found in the commercial traveller's amended bill, but which he said was there just the same. In the bill for a bottomry loan, a good charge could be made for interest, but concealed under the name of a charge to offset the perils of navigation. Unless interest is absolutely prevented in trade, it must be an element in insurance. Though always prohibited in the middle ages, it always existed in the trade of that time; and so it was necessary for those who carried on insurance to find some way of "whipping the devil round the stump." For ages, the bottomry loan was the scheme most in favour. Though indirect, and, therefore, inefficient, it was true insurance. As interest forced itself more and more into recognition, the direct and more efficient system of insurance became more firmly established. An edict of the Roman Emperor Justinian, A.D. 533, fixed the rate of premium on bottomry loans at twelve per cent. Concerning this edict, Gibbon, the historian of the Ro- 


\section{The History of Insurance Generally}

man Empire, speaks of it as relating to " nautical insurance," and says that " the wiser ancients" had not attempted to define the rates in this business. It seems to be true that during the early middle ages, even bottomry loans were not used in Latin countries. Just what system the traders used in order to average their losses is not clear. This is a matter concerning which, as it relates to neither court nor camp, the historians have but little to say. But the trading cities of the north, those that afterwards became the backbone of the great Hanseatic League, used bottomry loans, and also developed insurance upon modern lines.

Marine insurance, as we have it to-day, is, like nearly all our insurance, a British institution. The immense development of England's commerce was a consequence of the liberality of her laws; and as commerce developed-as is always the case-insurance developed likewise. A whole chapter, a whole book, in fact, might be written about Lloyd's, the coffee-house club that grew into a corporation of insurers, and is now the centre of the great merchant marine of Britain, and, it may fairly be said, of the world. The first great companies designed to carry on the business of marine insurance permanently and on a large scale were incorporated in England in 1720 . There were two of them, and they were floated during the South Sea Scheme inflation and narrowly escaped destruction in the depression that followed that era of wild stock-gambling. Though their birth took place under anything but creditable circumstances, they have survived, and have gained places among the most severely respectable trading concerns in that great world of trade which is known in England as " the City."

Though travellers tell us of tribes existing now, or, at any rate, within recent years, who have not a knowledge of fire, history cannot carry us back to the time when that knowledge was first gained by the most advanced races of mankind. The proverb about fire being a good servant but a bad master must have 
been among the first made, for loss of life or property by fire must have been one of the first contingencies of dawning civilisation. The need for insurance against this loss must have been very early felt. That need, however, would be comparatively little felt in those countries where civilisation first arose, for they had a warm climate, so that artificial heat was not a necessary of life, and food was commonly eaten raw. The use of fire, therefore, was not the every-day matter of course that it is with us. While I should expect to find the idea of fire insurance exemplified in the history of every country if I had the materials at hand in which to make the search, I do not pretend to be able to trace this form of protection back to the ancient Egyptians or any such people. Nevertheless, this form of insurance has a long history. Even a superficial study of the trade guilds of the middle ages will convince the reader that, among other things, they exercised the functions of mutual fire-insurance corporations. To have his workshop burned was a disaster to which every master of a trade was liable; and, left to himself, he would find the loss almost irreparable. But, the guild coming to his assistance, he could be restored to almost as good a position as before, and could continue the practice of his trade. It is said that these guilds are of Saxon origin. However that may be, it is certain that fire insurance was early introduced among the Saxons and other northern peoples. The great traveller and scholar, Du Chaillu, in his work, The Viking Age, tells us about this system of protection among northern tribes, worked as part of the village or clan organisation. Fire insurance has always been found to lend itself readily to operation on the mutual system, at least among agricultural peoples. The common and constant character of the danger, the equality of wealth, the stability of the property to be insured, and the common knowledge of the nature and value of that property possessed by all the parties to the contract made it comparatively easy to organise 
the business and also to head off frauds. As wealth increased, however, and as population became more dense and the inspection of the property insured became a business for experts, - in short, as neighbour-knowledge became less a protection against fraud,-fire insurance became a business by itself. Early in the history of joint-stock companies, this line of business was found to be very suitable for such concerns, and many corporations for the purpose of carrying on the business were organised. The great development of this business we owe mainly to England, a field peculiarly suitable for its growth, owing to the great accumulation of wealth there and to the universal and constant use of fire made necessary by its cold climate.

In many respects, the most important branch of insurance is that which provides for the widow and the orphan of the breadwinner-life insurance. It really is a pity that no hand has yet traced out for us the growth and development of this remarkable business. It is a composite of so many improvements and inventions; it has been affected by the growth of individual liberty in so many ways; it has done so much to aid the growth of modern civilisation, that its history could not fail to be of absorbing interest. The several streams that are united in the current as we see it are so completely merged in one, and the origin of the business has been so completely forgotten, that there is room for great difference of opinion when a historical analysis is attempted. 'As it appears to me, however, life insurance is a combination of many streams, three of which are worthy of special mention, even in so hurried a summary as this.

The first of these was the practice among travellers, already alluded to, of providing for their own ransom in case of capture. When, nowadays, we read of a citizen being captured by Italian brigands and held for ransom, we are apt to think of the act as a mere crime, just as we think of a burglary in one of our own cities. But such an act is really a survival, under 
exceptional conditions, of a common and accepted practice a few hundred years ago. In olden times, two cities or two countries, if they had not a treaty of peace between them, were at war, and the citizen of one ventured within the territory of the other at his peril. It was not only a proper but a meritorious thing for a citizen of the country thus "invaded" to seize the intruder. Merely to put that intruder to death would be of no particular advantage to anybody. But if he were "a citizen of credit and renown," like John Gilpin of humorous and immortal memory, the captor might reasonably expect a reward or ransom on restoring the captive to home and friends. As manners improved, this barbarous practice was left to less civilised peoples; but, even then, a man could hardly turn aside from the well-beaten path of travel without crossing the borders of some petty principality whose ruler exercised, rightly or wrongly, "the right of capture." And even on the main routes there was constant danger to the traveller, even though he were one of a large and well-armed company, of being captured by some band of marauders and carried off to fastnesses from which escape, except by ransom, was an utter impossibility. It can readily be understood that a man of property, finding it necessary to go abroad, would desire to provide in advance for his ransom. This he could do by paying a premium, just as in marine insurance, which, as we have seen, was well understood from the earliest times. This would seem to us a most uncertain business, for one would naturally suppose that the amount of ransom demanded would depend, not upon any arrangement beforehand, but upon the cupidity of the captors. But this was by no means the case. We have with us still such expressions as "a king's ransom," "a prince's ransom." These were not, when coined, mere meaningless expressions. In the days when the system-it might fairly be called a system-of capture and ransom existed, the ransom of a man was determined by his "condition"-his status in so- 
ciety. This made it possible for the merchant or warrior to estimate in advance, with more or less accuracy, the amount which would be necessary to purchase his freedom after capture. Instead of taking the form of a loan, as in the case of bottomry, the transaction was based on the lines of insurance as we have it to-day. The intending traveller would pay to the Jew-this branch of finance, like almost every other, was in the hands of the Jews-a sum of money sufficient to make it worth his while to ransom the traveller in case of his capture. To make such a business anything better than a mere wager, it would need to be undertaken in a sufficient number of cases to enable the guarantor or insurer to get the benefit of average, just as the life-insurance companies do to-day. This form of bargain never gave rise to a separate trade or business, I believe; but it merged, as one can see it might easily do, into the system of life insurance. For the merchant, whether at home or abroad, had other dangers to fear than that of capture by the enemies of his country, and would naturally seek, by insuring his life, to provide against the effects upon his enterprises of those dangers.

Another confluent of the stream of life insurance had its rise in the need felt by traders of guarantee against unfavourable political events-using the word "political" in its widest sense. If, for instance, while some caravan was labouring its way marketward, laden with the riches won in some far adventure, war should break out with a neighbouring country to that through which it was passing, the goods might be given up for lost; for the soldiers of one side or the other would be pretty sure to capture them. The merchant would willingly pay in advance to be insured against such a disaster. Now, the making of war and peace, the success of a negotiation or a conspiracy, is largely a matter of men; according as certain men live or die, we can pretty well predict the immediate future in public affairs. For instance, James II. of Great Britain was 
the tool of the French king in foreign affairs, because he wished, above all things, to bring about certain changes in the internal economy of his own kingdom. On the other hand, William of Orange, who succeeded James, had been from his very boyhood the leader of a vast and changing compact to humble Louis and break the power of France. William's accession to the throne of Britain, therefore, changed at once and completely the foreign relations of the kingdom. For a time, it required all William's great skill and coolness to balance himself upon the height which he had gained. The question of his life-or death involved many other questions as well, questions of free or of hampered trade in many directions. A drop of poison, the dagger or pistol of some concealed enemy or hired assassin, even too long a residence in the damp and murky air of London, might end his life, and, with it, end the hopes of those who had ventured their wealth upon the future that he personified. The death of William at that critical time would have caused greater loss than the most terrific storm at sea or the most outrageous acts of Barbary pirates. To be insured against such a contingency, therefore, was a matter of the first importance to merchants. A system arose of insuring lives that were regarded as an important element in the success of pending operations. How that system was abused we shall see as we continue our investigation.

Still another stream whose waters are mingled in what we now call life insurance is the system of annuities. In the more restricted financial operations of a hundred and more years ago, the sale and purchase of annuities had a much greater place than they have to-day. This system seems to have been used as a favourite means of accommodating the needs and wishes of the people to the land and usury laws. It is true that, in England, an annuity was a charge upon personal and not upon real estate, the latter being called a rent-charge. But, as well as I can judge, this distinction was not made in common 


\section{The History of Insurance Generally}

speech. The fearful complications of the land laws under the feudal system as developed in Europe made it difficult, and, in some cases, impossible, for the lord or owner to alienate his title. In order to raise money, therefore, the owner resorted to the expedient of mortgaging the revenues of his estate, a comparatively simple matter. Thus, for the loan of a certain capital sum, the landlord would guarantee a fixed annual return for a term of years, for a lifetime, or even in perpetuity. It will be manifest that though such a bargain might contain a specific declaration that the loan should not bear interest, the interest might be concealed in the rate or justified under the name of compensation for unusual risk, expense of collecting the annuity, or difficulty of getting in hand the sum for the loan. As Shylock put it, though declaring that he would " take no doit of usance," yet

in merry sport,

If you repay me not on such a day,

In such a place, such sum or sums as are

Expressed in the condition, let the forfeit

Be nominated for an equal pound

Of your fair flesh, to be cut off and taken

In what part of your body pleaseth me.

The church and the law might put usury under the ban, but they could get no hold upon usurers who thus concealed their operations.

This system of annuities developed not in the direction of life insurance alone. To it more than to any other single cause we owe the perfection of the great mathematical theory of probabilities, and also our science and art of vital statistics-which, in their turn, have become two of the great working tools of life insurance. As to that, some further facts will be given when we come to consider the life-insurance system by itself.

One can see, by following these annuity transactions in imagination, that from the payment of a capital sum to secure an income to the payment of an annual premium to secure a 
capital sum-which is the ordinary life-insurance transactionthe distance is a comparatively short one and one that would be covered by few and short steps in commercial development. It requires no great penetration either, to see that in these annuity transactions, with young, foolish, and profligate landowners on one side, and the most avaricious and unscrupulous money-lenders on the other, the chicanery was varied and endless. Could one but learn and place before the public, for instance, the history of Audley,-" the great Audley," - the famous money-lender of Elizabeth's time, what a lurid drama of real life would be presented!

Were I appointed, then, to write the history of life insurance, I should trace the stream to three heads: ransom insurance, the insurance of the lives of the great for the protection of traders, and annuities. Each of these contributed its quota, as did other inventions, of course,-and the historical outcome of each is to be seen in this great business as we have it to-day.

As with the great branches already briefly dealt with,marine, fire, and life,- - so with the others. Every form of insurance is the outcome of special circumstances and has grown up to meet some special need.

In a world that lives from hand to mouth, the most obvious danger facing the wage-earner is loss of work, and so of wages, through sickness, bodily accident, or the closing down of the establishment in which he is employed. Even idle time must be lived through, and family expenses cannot be greatly reduced, even though the stream of wages has been interrupted in its flow. To provide against loss of wages through the closing of factories, a form of insurance has been in use in France and some other countries known as "chomage"; but it does not seem to be either a very large or a very successful business. Indemnity for loss by accidents to workmen is compulsorily provided in England and some other countries by statutes commonly known as employers' liability laws. The 
liability thus thrust upon employers is commonly shifted, or, more properly speaking, distributed, by employers' liability insurance, carried on by regularly incorporated companies.

But, for general accident, sickness, and out-of-work insurance, vast sums are provided by trades unions and other workingmen's organisations. The peculiar nature of their business, if it can be called a business, makes it almost impossible to carry it on as insurance is ordinarily carried on, by great joint-stock companies. If between the beneficiary and the paying company, or between the paying company and its agents, there is no relation but that of what Carlyle calls the "cash nexus," fraud and the expense of detecting or preventing fraud so clog the machinery that it cannot work. But if to the idea of so-much-for-so-much is added the idea of friendship, or even mutual interest, as among the workers in one trade or the members of one brotherhood, the feelings of selfrespect and loyalty to the common good prevent, in large measure, impositions which would otherwise be practised, and also win from the members services as visitors, inspectors, canvassers, and so on which could not be bought in the market for ten times the whole amount paid. All this is quite compatible with relegating to paid officers the mere clerical work, just as it is compatible with paying the printer for work done for the order by him. But, even though this is often not called insurance, and though it is carried on upon what is known among insurance men as the mutual or co-operative system, yet, to the extent that it indemnifies for loss, it is true insurance. If it is but little dwelt upon in the succeeding pages, that is not because the system has not its own peculiar temptations to avoid or its own sins to answer for, nor is it because of any failure on the part of the present writer to recognise the importance of this branch of the subject. The principal reason for treating it but lightly is that which compels the close condensation of many important matters and the total omission of others- 
want of space. The records in such cases, also, are not always of a public nature, and cannot always be quoted. Moreover, the evil wrought by a voluntary and co-operative society, though it may be great, is comparatively easy to understand and to remedy. Those who feel aggrieved simply drop out, and the bad society is thereby killed, leaving the work to be done by a better organisation, if it is thought worth doing at all. Still, some of the more glaring cases of injustice, fraud, and demoralisation in which these concerns have figured find a place, though necessarily in condensed form, in succeeding chapters.

The danger to a poor family of being called upon to face ruinous expense, through the sickness and death of one of its members, - paying the doctor and undertaker, buying mourning, and so on,- - has led, in some communities, to the formation of insurance societies to distribute the loss thus occasioned. "Burial clubs" these institutions are often called. It will be necessary to make special reference to this branch of insurance, for its crimes are many and black.

Accident insurance is one of the more recent forms of indemnity. This business can be, and is, carried on by great companies. Though it may be considered a modern institution, in its present form, yet it is but a slight modification of ideas long in use. It is designed to indemnify for loss sustained through "outward and violent accidental injury." While medical and sanitary science have, in our time, combined to lengthen life, or, in other words, to decrease the number of deaths within a given time, it is doubtful if men engaged in making a living are not more exposed to danger of injury or death through accidental violence than ever before. Though the laws are, in the main, stable, though governmental disturbances are of a kind to affect men's bodies less than those of former days, still, there have been changes to offset the advantages thus gained. People travel by artificial means more than they formerly did. The machinery used in the production 
of wealth is constantly changing, while increasing in quantity, with the inevitable result of sacrificing limb and life by those engaged about it. Our modern tendency to sacrifice solidity to considerations of appearance, haste, and cheapness, also works out in maimings and killings without number. To these facts, and to the necessity constantly before the earner of keeping the flow of wages going, even when accident drives him from the pumps, is due the modern development of accident insurance. This branch of business also has its abuses; but as they are of a character to surprise, or even amuse, rather than to shock or warn of impending social danger, I refrain from dealing with them at length. A man who practically makes a living by having minor " accidents" happen to him-breaking his fingers, bruising himself by falls, even fracturing a leg or two when nothing less will serve his turn-would be regarded by most of us as a rather strange development of this humdrum life of ours. Such cases and others only less surprising are among those that must be taken into account in accident insurance.

In countries in which storms are a considerable source of industrial loss, these losses are insured against. In many cases, the fire-insurance company's policy is made to cover loss from lightning, whether fire ensues or not; and thus to insure not only property housed in stated buildings, but also cattle in the fields, it may be miles from the owner's dwelling. The disasters of wind and flood are also insured against, thus enabling the man whose place is swept bare to resume his work with all the advantage of ready money to replace buildings, machinery, and other wealth-producing appliances.

It would be merely wearisome to catalogue here the many ways in which the insurance principle is usefully employed in these days. But it may be stated generally that there is no form of risk of financial loss that cannot be provided for by insurance. Many branches of the business are still in the same 
state of development as was ransom insurance during the early middle ages-there is, properly speaking, no system, and not a sufficient number of policies issued to base upon them a separate trade. In great financial centres, however, there are capitalists who, for due consideration given, will assume any risk. Where the class of risk affords opportunity for the issue of but few certificates or policies, a relatively high premium must be charged, or the class of risk must be merged with some other in the capitalist's calculations, so as to give him the benefit of average. In a current magazine I find an article on Lloyd's which gives examples of strange insurances. One of these is a curious instance of insuring the lives of the great, which has already been referred to. The writer says:

A celebrated singer recently took out an insurance in Lloyd's on the life of Queen Victoria. She paid a big premium on account of the age of the Queen. The reason the singer did this was not because she cared anything more than most folks for the Queen, but because the contract to sing would have been abrogated by the Queen's death, which would have plunged England into mourning and prevented the singer's appearance in opera.

Among other curios of insurance are these: Insuring the voice of a prima donna; insuring elephants and animals of all sorts ashore and afloat; insuring the gate-receipts of cricket and football matches; insuring against twins. This last is spoken of as " a favourite form of insurance," and we are told that "a well-known underwriter is always ready to lay a thousand to one against twins." Here is another strange case, one that, one would think, must be almost unique: "A tradesman in a London street, who has an impression that a monument may fall on his shop, has taken out a policy at a nominal premium of two shillings and sixpence per cent."

Here we see varieties of insurance, some of which, such as the insuring of animals, - no doubt, the reference is to wild animals kept in captivity for show purposes,-might well be expected 


\section{The History of Insurance Generally}

to develop a regular system and to be taken up as a separate trade, for the number and size of zoölogical collections seems to be constantly increasing. The writer already quoted mentions insurance against burglary as a specialty. But time was when companies for this special purpose were organised, and of late we have come back to that position, companies for in. surance against burglary being in existence in the United States, Great Britain, and elsewhere.

It must be evident to anyone who will look at the matter for a moment that modern trade, and, therefore, modern society, would have been impossible but for the development of this great protective art of insurance. Trade has always had her votaries, and among them have been some of the most magnificently daring of mankind. Not merely life, but fortune and reputation, have been risked a thousand times by men who sought only a financial profit as the result of their adventure. Storms, pirates, privation, extremes of heat and cold, laws and the living representatives of majesty, the less substantial but more awful dangers conjured up by superstition-these and every other conceivable peril and obstacle have been faced again and again by those who seek for profit in the paths of trade. But the greater the danger, the greater the inducement that must be offered to men to face it. Who but a lunatic would imperil life and fortune in a venture the highest possible rewards of which were bare wages and bare bank interest ? Great risk and a great ratio of profit, however, are alike accompaniments of small trade. A great commerce is impossible, except under stable and easily managed conditions, and at a low rate of profit to the adventurer. The saying that "competition is the life of trade" is incomprehensible, unless it be interpreted "a small profit is the life of trade." When merchants were able to buy for little from the craftsmen of India the product of their almost magic looms, and to sell those stuffs at enormous profits to the great lords of Western Europe, whose 
incomes represented the toil of hundreds and thousands of serfs or tenants, a straggling caravan, forcing its weary way across the desert was sufficient to bring to market all the goods necessary to satisfy the demand. The risks were great, but the profits were concomitant. Trade lived, but it could not grow under such conditions. As the state of the laws improved, and the trader found himself upon surer ground, profits fell. And, as profits fell, trade grew. The goods were demanded not alone by the great and wealthy, but by those in more humble position. This, in turn, made it necessary to clear, straighten, and make free the highway of commerce. And, with the accomplishment of these things, the ranks of the traders increased, and competition proved to be indeed the life of trade. With great profits in sight, of course, nothing would keep out of trade adventures the more daring spirits; but only stability and a reasonable certainty of a fair day's wage for a fair day's work could win the co-operation of the more timorous. Insurance, more than any other single force, has aided in establishing security. It is a contrivance which is wholly within the control of those most deeply interested; and not only that, but it places all other contingencies under their control as well. No matter what the risk to the goods or property may be, the alchemy of insurance transforms them into elements of security for the trade adventure. No matter what the ratio of loss may be, if insurance is used the ratio of profit can be counted in advance with certainty.

There is great temptation here to drop into figures, to try to stun the reader's imagination by presenting to the eye statistics showing the incomprehensible vastness of this modern business. This temptation is all the greater because such figures are easily available by anyone at all acquainted with insurance literature. But it may be necessary to use figures in later chapters, and it is well to avoid unnecessary extension of an evil which will probably be great enough at the best. It may 
be stated in a general way, however, that marine insurance amounts, almost dollar for dollar, to the value of the property afloat in the world in anything larger than a skiff, including the expected profits of every pending adventure. As to fire insurance, the amount of it may be measured by not less than three-quarters of all the property in the hands of traders in the civilised world. Life insurance, though but comparatively little practised until our own time, has been making very rapid progress in all countries with stable institutions. American and European companies are now extending their operations to oriental lands and among people to whom life insurance, as we understand it, has hitherto been unknown. The total life insurance now in force would give an average of $\$ 500$ for every living male of insurable age in the English-speaking countries of the world. In the same way, other branches of insurance have grown with the growth of property and trade.

Having thus summarised, though briefly and imperfectly, the history of insurance generally, it becomes necessary to take up the great branches one by one, and to consider them from the point of view indicated by the title and introductory chapter of this book. To search the record will be to go through many painful scenes, and to see human nature in its most unlovely light. If we were impelled by a mere morbid desire to read the records of crime, or to consider the monstrous and unsightly in social life, it would be well to stop here. Such, however, is not the object. The pathologist studies diseased conditions, not because his eyes have become distorted or his. mind morbid; not because malformed limbs and putrid flesh afford more pleasure to his sight than those having the beauty of health and soundness, but because it is necessary to study disease in order to cure it. We dare not close our eyes to these bad conditions, for diseases, like weeds, flourish by inattention. The social body, like the individual body, has its plagues, its morbid conditions, its peccant humours. These 
must not be endured; they cannot be endured; for the body, if not rescued otherwise, seeks relief in death. We must face the devil of disorder and exorcise him. This we shall do, not by incantations, not by mummeries of superstition, but by patiently studying the nature of the disease and applying a reasonable method in scientific fashion. Knowledge is not power only; it is safety.

In this spirit, let us consider the facts. We turn to the oldest form of insurance, considering first the nature of the business and of the abuses to which it is liable. 


\section{CHAPTER III}

\section{MARINE INSURANCE}

Nature of this Business - Its Technical Character - Special Dangers of Abuse-Effects of Abuses upon those in the Trade, and upon the Public - The Facts as Seen and Used by Creative Writers.

$M^{2}$

ARINE insurance, as has been indicated, must be as old as trade itself. As soon as ships in any considerable number began to traverse the sea in the holy cause of peaceful commerce, the men whose fortunes were embarked in them must have sought this means of protecting themselves from utter ruin through the unknown and incalculable perils of the deep. It is usual for a trade to grow up under usages and traditions rather than under statute laws; and only when certain progress has been made does the law-making power, whether king, estates, or people, recognise the newcomer and begin the work of regulation. Marine insurance comes to us out of the unknown past, with its traditional and esoteric practice, and its complex laws to a great extent fixed and settled. Its very abuses are so aged as almost to have the force of right by prescription; and so constantly have they been associated with the business that one is in danger of considering them as part of the system itself.

In dealing with marine insurance, one deals with a subject technical and complex above almost any other that can be found within the range of human practice or philosophy. It has, as suggested, all the mystery of age. There seems to 
attach to it also something of the mystery of the great ocean which, though traversed by men for countless generations, is unknown, except in small degree, even to those who have spent a lifetime upon it. A good way of judging what a strange and little-known business this of marine insurance is, is to take up a file of an insurance journal and look for news and comments relating to it. You will find twenty columns of matter about other lines of insurance for one that deals with this oldest and, in some respects, greatest and most important branch. Why? Because these others are more easily understood by the editor and more easily explained to his readers. Or, ask a man engaged in the business for an explanation of any point that is not clear to you, and note the effect upon your own mind of his answer. The technical terms, - or, rather, the technical use of common terms, - the references to ancient usages and to laws unknown to ordinary people, the assumption of knowledge on your part of the ways of ships and sailors,such things as these will make you glad to escape, that you may find some more understandable authority to explain the explanation.

The trade of the sea has changed many times since it began. New continents have been discovered, and with them new materials for cargoes. Old nations have disappeared, and with them whole systems of trade. But, through these deep-reaching changes, marine insurance has remained about the same. No matter whether the goods insured were a cargo of slave girls en route from Alexandria to Rome, carried in a galley propelled with oars, or a consignment of electrical apparatus from San Francisco to Melbourne aboard a steel steamer, the system of insurance must be essentially the same- so much paid by the insured on condition that the insured shall make good any loss, according to a scale agreed upon, to be agreed upon, or to be decided by some outside authority. It is reasonable to expect that such a business, coming down to us from 
the time when laws seemed designed to hinder rather than help commerce, will bear upon its vast bulk some of the barnacles of ancient abuses.

Another thing that has made marine insurance a particularly good breeding-ground for fraud and other crimes is the difficulty of proving any alleged wrong. A ship leaves port with everything apparently in her favour. A few weeks or months later, her captain and crew return as shipwrecked mariners upon another vessel, and report that their ship has gone to the bottom as the result of foul weather. Even though it may be known that, as a matter of fact, the insurance money paid to make good the loss is far more than enough to compensate the owners, who is to prove that the ship was deliberately thrown away? Even though the crew suspect that the leak was too great to be accounted for by the straining of the timbers; even though they believe that the master deliberately refrained from using the knowledge of navigation that he possessed, and so let her drift to destruction when he might have saved her, how can they prove these things? Or how dare they attempt such proof and fail? We know that vessels have left port with every apparent assurance of a safe and speedy voyage, and have disappeared from the sight of man, both they and all they carried, as completely as though they had been turned to water and had mingled with the ocean. The only explanation of this disappearance given by those who know most of what might have happened is no explanation at all, but rather a confession of utter and hopeless ignorance. The fate of such vessels is but a part of the greatest of all physical mysteries, the mystery of the sea.

If the returned master of the foundered ship tells those who have rescued him and his crew that his vessel sprang aleak by running upon a reef, and though it is known, and even afterwards demonstrated, that there is a hundred fathoms of water for hundreds of miles around that spot, who can say that the 
master's statement is a lie? Do not islands sometimes rise from the bottom of the sea in a night, only to subside as quickly? Even though it can be shown that it is a physical impossibility for a shoal ever to have existed within two days' sail of the spot, the master's statement may still be honest and substantially true. He may have run upon a half-sunken derelict, that most terrible of all the monsters of the deep. If, in the confusion attending unexpected, instantaneous, and supreme calamity, the master believes that the vessel has rocks and not water-logged timbers under her forefoot, who will find fault with him or question his veracity for that?

It is not without reason, but because of necessity, proven by ages of experience, that the laws relating to ships and sailors make the captain of a vessel at sea an autocrat. Once the vessel leaves port, her safety and the safety of all on board depends absolutely upon the directing mind so to handle ship and crew as to overcome or outwit the sea. A failure of attention, a failure of knowledge, a failure in calculation by an apparently inconsiderable fraction, may mean the doom of ship, crew, and cargo. And as the honour and ability of the captain must be trusted even with matters of life and death, such as, on shore, are guarded with laws and juries, so must his word be accepted, in the absence of other evidence, in explanation of any disaster that may befall between port and port. He may misrepresent the facts; but nobody else can even do that much. Still less can anyone state the facts as they really were. It is true that, in the excesses into which the possession of absolute power will lead a bad nature, a captain may sacrifice to petty spite or mere malignity the life of one of his crew. If he so far forgets himself as not merely to do such a thing, but to make it clear to others that he has done so, he is answerable, as a murderer, to the courts of his country. In the same way, if-as we shall find has often been done-a captain throws his ship away openly, flagrantly, and with the manifest intention of selling her loss 
to the insurers, he not only commits a crime, but also establishes his own guilt and makes his punishment certain.

The power of the skipper to throw away his vessel and still escape with his life was the central point of centuries of evil. As conditions changed, so the application of the idea changed, and so were changed the statute laws and commercial systems designed to prevent the criminals from taking money from insurers fraudulently by this means. At times the forces of honesty have prevailed; at times the forces from the pit. As in so many other matters of social development, so in this-our own time shows the greatest and most remarkable changes. Men still living have seen the world almost at its worst in this respect and also at its best. I am speaking now ouly of individual acts of barratry and the schemes of forgery, misrepresentation, and overreaching that grew out of them, and not of what may be called social lesions or abuses. Modern conditions make the sea criminal of this class impossible, except in special cases or out-of-the-way corners of the ocean. The insurance companies are so great, their agencies so far-reaching, their resouces so vast, and their power of combination for the detection and exposure of fraud so complete that crime is repressed and honesty and sound business proportionately encouraged.

But when we wish to read an account of what was, we need not turn to the literature of an older day; we take up Kipling, the poet who has given the imagination of our own time a new grip upon things and has made a new series of word-pictures possible. By the touch of genius, this literary thaumaturgist can expose the inner working of any trade. He came to maturity soon enough to hear and understand the last dying confession of the thief and murderer who, as shipmaster, had wagered his own life and those of his subordinates in the fierce game of wrecking vessels for insurance money, and this confession he has given us in The Mary Gloster. It will be 
remembered that the hard-fisted old millionaire shipowner and ironmaster is on his deathbed, and is using the last remnants of his strength and his vulpine craft to induce his son to carry into effect his long-devised scheme, half superstitious, half sentimental, of having his body buried at sea at the place where he had committed to the deep the remains of his early love, his wife. Literary criticism may be out of place in a work like this, and on the part of one who has no place in literature; nevertheless, I venture the opinion that there is not in any English book a more perfect creation than this old dying reprobate, who yet has the virtues as well as the vices of the pirate, to which class, in less civilised times, he would have belonged. Recounting his life, the old man tells with what daring he fought against poverty, and at length, turning the enemy's flank, made his fight not a defensive, but an aggressive one, and in the end conquered wealth satisfactory even to himself. In the early days he was employed by others as skipper; and he says:

I did n't begin with askings. I took my job and I stuck, And I took the chances they would n't, and now they're calling it luck. Lord, what boats I've handled-rotten and leaky and old : Ran 'em or-opened the bilge-cock precisely as I was told. Grub that 'ud bind you crazy, and crews that 'ud turn you gray, And a big fat lump of insurance to cover the risk on the way. The others they durse n't do it; they said they valued their life. (They've served me since as skippers). $I$ went and I took my wife.

"Ran'em-or opened the bilge-cock precisely as I was told." What a picture this conjures up of disaster at sea, disaster brought to ship, crew, and cargo through the almost unthinkable treachery of the man who was supposed to venture his very life, if necessary, to save the last man and the last bale aboard; treachery arranged in the snug office ashore where are ensconced the owners whose strong-boxes contain the signed and sealed covenants of the " big fat lump of insurance" which is to turn this " unexpected calamity," this "visitation 
of God," into jingling gold or crisp bank notes, and so into comforts and luxuries for the c:iminals engaged in the conspiracy.

If the reader prefers to take his facts not dry and cold, but dished up in appetising fashion, let him read not only The Mary Gloster, but also Charles Reade's Foul Play. This is a story turning upon an elaborate marine-insurance fraud. The reader will encounter there one of these old-time sea captains in full career as a wrecker, will hear him recount some of his many criminal exploits against insurers, and will see him at last go down in midocean with his scuttled vessel, a victim not so much of this his last villainy as of drink and the loathsome superstition of blind obedience to owners which generations of false teaching had worked into the very bones of British merchant seamen. In reading this book it should be remembered that Charles Reade's reputation depended not so much upon his ability to embody men and women in the printed page, or to relate imaginary incidents in interesting fashion, as upon his capacity for hard work in the collection of facts. He was the most devoted scrap-book keeper and reader of government reports to be found in all England. From him we get the facts at second hand, but facts he certainly believed them to be.

As hinted above, out of this throwing away of ships grew a thousand subordinate crimes. A suggestion of these can be had in Robert Louis Stevenson's little novel, The Ebb-Tide. Those who have not the good fortune to have that reading in store will remember how the three beach-combers on an islet in the Pacific steal away a vessel that has put into port there, risking, as they suppose, pursuit and capture, with the certainty, in that case, of dire punishment for piracy. The ship's cargo is entered as California champagne. One of the pirates, a thirsty soul, drinks his way through the outer tier of cases, and finds -at first to his disgust, but ultimately to the joy of all-that 
the "champagne" in the second tier is only a fair sample of water, while at the back there is nothing but Romeo's apothecary's "beggarly account of empty boxes." It is as plain as sun at noonday that the vessel as she stands is complete and unanswerable evidence of an insurance fraud, the owner having insured to the full, put in a bogus cargo, and sent the ship to sea with the tacit understanding that she shall be cast away by the captain. Thus the pirates find their crime shielded by the crime whose consummation they have prevented. Taking this story simply as a hint-and others could be named were it worth while-we can infer what ramifications these frauds must have had; how, in one way and another, all kinds of people connected with shipping must have taken part in them; how perjury and forgery must have been made systematic, and how conspiracies must have lived on sufferance until they became almost a part of the business.

All these evils have, in fact, arisen; all these crimes have flourished, menacing the trade and morals of nation after nation dependent upon sea-borne commerce. In succeeding chapters, some facts will be given, but only illustratively, for even a catalogue of these offences would occupy a book, and a history of them would almost make a library.

It will occur to many that, as the captain cannot throw his ship away without endangering his own life, this trade would soon die out for want of men bold enough to carry it on. Undoubtedly the danger had a repressing influence. Yet Kipling, Reade, and the others who have made these desperadoes live before the eyes of all of us were not mere romancers. Absurd, impossible as it may seem, the abuse of insurance has, more than once in history, bred a class of men ready to risk their lives for a comparatively small share of the money they "earned" by casting away ships they commanded. At times, in fact, this has been by no means a dangerous trade, for there were islands and other places unwatched by police or by insurance 
inspectors, where vessels could be "wrecked" in the gentlest manner. As these points were brought under surveillance, the game became more dangerous, and more desperate grew the ruffians who staked their lives upon it. Some, like the master of The Mary Gloster, not only ventured it, but even found she-fiends to mate with them, and encourage and assist them in their crimes. And when we consider that the policing of every port, reef, and coast made it more and more easy to use the vessel's hull as evidence against the barrator, and drove him to destroy that evidence by sinking his ship in midocean, taking the fearful chance of the open boat and possible starvation, with the further possibility of the gallows if he should reach shore, we can realise partly the kind of desperadoes that this business developed.

It is true, however, as already stated, that such characters have gone out of the world along with the bandit and the buccaneer. They made a gallant fight, but they could not press back the advancing power of civilisation; and that power killed them off and left their breed no room. As an illustration of this, take the experience of the shipping trade of the United States. A couple of generations ago fraudulent losses were common. But the change of conditions has put the business on an even keel of honesty in this respect. I am informed by Mr. Kingman N. Putnam, of New York, an authority of the first class, that, during twenty-five years' experience in settling marine-insurance losses, he has known but one case of deliberately attempted fraud, and that one was unsuccessful, and resulted in the ruin of all implicated in it.

Marine-insurance abuses do not cease, however, with the suppression of the barrator and his accomplices and dependent criminals. Though all aboard may be honest in their efforts to bring the vessel safe to port, those ashore who are interested in a loss may take their own way of bringing about what they desire. As the pitcher that goes too often to the well is broken 
at last, so the vessel that goes too often to sea will be lost; and, in the meantime, if she is faultily constructed, overloaded, badly found, or inefficiently manned, she may have a profitable career as the basis for insurance claims. Just as social ills, such as monopoly or war, are worse than individual wrong-doing, so the evil of making trade an excuse for insurance gambling is worse than even the hideous crimes that the creative writers depict, for they mean wide-spread demoralisation. As we deal with the facts, the reader will be able to realise this more fully. This demoralisation works far beyond the point of its origin in society. It injures the traders, who, as all agree, are the brains and heart of a maritime nation, and injures no less the sailors, who are its backbone.

We are too apt, in thinking of social ills, to follow the fashion of the second-class playwrights and novelists and divide our fellow men into two classes-those who are good and cannot be corrupted and those who are bad and cannot be reformed. Real society, however, has no characters of either class, but is made up of people who sometimes do right and sometimes do wrong, and even the best of whom are apt not to cross-question themselves as to their motives when doing in their own interest what is sanctioned by common usage. Few and far between are the men who can withstand a custom, even when they think it is a bad one; and bad customs are likely to grow when self-interest is in their favour. Take, for instance, two shipowners of different character. The first is engaged in a legitimate trade; his vessels are right in every particular; he insures ships and cargoes merely to protect himself from ruin, having in mind not only himself, but those dependent upon him for their living, and creditors to whom his honour is pledged no less than his goods. Such a man's profit can only be a fair one, for he makes it in open competition with the world, and it can only be the result of knowledge and industry nsed for the benefit of all who deal with him. His neighbour, 
on the other hand, proceeds on the principle "Make money, honestly if you can - but make money." His ships are the very reverse of those sent out by the first man, and are insured for far more than their value. One old tub is lost, owing to "the fury of the elements," as the sympathising newspapers will put it. Out of that one murderous fraud the owner will make more than the honest man can make out of a year's operations. Between these two there is a great moral difference, but the numberless grades between are all filled up, and the men in the business shade imperceptibly from the very good to the utterly vile. And the hackneyed words of Pope about men growing so familiar with the face of vice as to be led on through the stages of toleration and pity to loving acceptance have become hackneyed partly because they are so fearfully true. Let frauds such as we have spoken of be repeated and they will grow respectable, and only those very few who regulate their acts by their own consciences, instead of by what other people say, will refrain from them.

But there is even more than that in it. If a vicious condition lasts long enough, a generation grows up under it knowing no other, and the people of that generation are likely to regard the immoral condition as unquestionable, or, if questioned, as inevitable and so endurable as a matter of necessity. Mr. W. Clark Russell, the greatest spinner of sea-yarns in our day, has a little sketch, $A$ Salt-Water Cure, telling of a shipowner who has been accustomed to send vessels to sea provided according to a standard which seems to him reasonable, and who takes a voyage on one of his own ships merely to show his faith in the seaworthiness of the craft. As a matter of fact, though a good fellow in his way, he has been making his money by subjecting his sailors to fearful risks, he being protected from loss by full insurance. The tale turns upon his disillusionment in the course of the voyage he has foolhardily undertaken, and the different view he gains of the perils of life 
in the old craft he has been running. For one man restored to morality by this salt-water cure, hundreds, if not thousands, of shipowners would live and die quite unconscious of any wrong on their part in sending ships to sea that are a menace to the lives of those aboard ; while others, not mere compliers with usage, but wilful murderers for the sake of gain, would make it their business to send out ships as bad as the insurance people would take and the poorest of sailors would man. An abuse of this kind would attract no attention until it grew into a serious evil ; and, by that time, reform would have become exceedingly difficult, having the inertia of established custom to overcome.

If the poison of insurance abuse is allowed to work unchecked, like poison in any animal organisation, it tends back toward the seat of life. If more can be made out of bad ships than out of good ones, not only will ships be kept afloat beyond their lifetime, even when they have become hulks whose only possible port is the bottom of the sea, but bad ships will actually be built. The art of shipbuilding cannot improve as rapidly as it should, when a premium is offered it to forget what it has already learned. Vessels may be built larger, speedier, more convenient; but in the one essential of safety, the tendency will be in the wrong direction. And the same is true of the even greater art of navigation. In handling these craft whose safety is little cared for, the best of navigators are not needed, and, so far as these vessels are concerned, improvements in the art of navigation and in the tools of it are repressed rather than encouraged. This repression will have its effect in keeping away from the seafaring life the men who are best fitted for it, and in driving into it men who are mere labourers. This phase of the matter is worthy of separate consideration for a moment.

You cannot throw away ships or send bad ships to sea without at least endangering the lives of sailors. Let such a system 
as this of overinsurance on marine risks become established, and the result must be that the man who follows the sea for a living makes every voyage, as it were, with a price upon his head. An owner who has no reason to desire the safe return of the vessel he sends out would be a fool indeed to employ competent and high-priced labour to handle her. He wants for his service, not men who know their business, and who demand fair wages and decent treatment, but mere slaves, unfortunates who, like the murderer in Macbeth, would set their lives on any chance to mend them or be rid of them. We can imagine the class of sailors such a system would breed. But we do not need to imagine them, for they are set before us almost in flesh and blood by Kipling, in his Ballad of the "Bolivar," and there we are told how they work and what their outlook upon life is.

Seven men from all the world back to Docks again, Rolling down the Ratcliffe Road drunk and raising Cain,

-thus begins the bacchanalian blasphemous chantey of one of the men who have just escaped, as by a miracle, from a deathtrap in which they had been sent to sea. The picture of the crazy craft in her struggle with the sea is, of itself, enough to cause one to hold his breath in fear. But, terrifying as this is, worse, far worse, is the sight and sound of those poor creatures the sailors - sodden, embruited men, clinging to life for life's sake alone. In grips with the great Mystery, they yet feel neither abasement nor uplift; panting, but not praying, with no more sense of their own life or what it means than has the wallowing old tub that bears them, they make their way back to port. Yet not without a sense of where the real danger lay - not in wind or wave, not in fewness of hands or ill-stowed cargo, but in "the money paid at Lloyd's" that "caught her by the heel" and made the very stars to reel as the vessel staggered and tumbled. So little humanity is there 
in these unfortunates that the greatest of all experiences leaves them with no feeling save a ghoulish joy at their escape, expressed in drunkenness and riot. But, with insight and justice worthy of a poet, the author puts the responsibility for the moral condition of these poor creatures where it belongs. In the final stave, the rioter roars :

Just a pack o' rotten plates puttied up with tar, In we came, an' time enough, 'cross Bilbao Bar. Overloaded, undermanned, meant to founder, we Euchred God Almighty's storm, bluffed the Eternal Sea!

And with sardonic humour which smells of the sulphur of his blasphemy, he closes:

Seven men from out of Hell. Ain't the owners gay, 'Cause we took the "Bolivar" safe across the Bay?

"Meant to founder." There is the point. Could a race of freemen be found who would allow their masters thus to make money by sacrificing them? Could a race of slaves show the daring called for by such mad enterprises as this? Creatures combining the qualities of brutes with those attributed to fiends would be the only ones with which to man these doomed vessels. And the growth of such a race is one of the most fearful results of a long continuance of such abuses as we have been considering.

It will occur to those not familiar with insurance that, instead of being willing to make good losses due to the negligence or bad faith of the owner or his agents, insurance companies would confine themselves to paying losses due to unavoidable accident. This, in one form or another, is a question that arises in connection with every branch of insurance. Often in practice insurance companies insist that the property insured shall be changed in certain ways before they will insure it. For instance, in fire insurance, it may be made conditional that walls between two parts of a building shall be of brick with 
doors of iron. Insurers might, if they chose, refuse to issue a policy on any ship not built in accordance with certain specifications. The effect of such a method, if intelligently carried out, would be to lower the loss-rate. But if competition were free the lowering of the loss-rate would lead to a lowering of the charge for insurance. The result would be that shipowners or the public would be benefited, but insurers would not be benefited. Reason and experience lead many insurance managers to the practical conclusion that it is not their business to prevent losses, - taking, in this respect, the view expressed in a previous chapter,-but to estimate the losses, divide the risks into general classes, and charge each risk, according to the average of its class, enough to cover the average loss together with expenses and a profit. This is not al ways the attitude of insurers. Sometimes they have prescribed the physical condition of property insured; sometimes they have sought modification of the statute laws under which their business is carried on. When insurers leave the making of risks to owners and the making of laws to legislatures, and confine their attention to the distributing of losses as they find them under conditions as they exist, they perform completely their function in our economic system.

Thus far, we have dealt only with those forms of wrong which are carried on against the interest of the insurer. It is only fair to say, however, that the insured are not the only people of whom complaint is to be made. In fact, on many occasions, acts of bad faith on the part of the insurer have been the excuse, if not the occasion for such wrongs as we have been describing. Such acts of bad faith cannot well grow into a system of very great extent in connection with marine insurance. An insurer here or there may deny a just claim, or may so sequester his estate as to make it impossible for the loser to recover his money. Such an act may even be repeated until it becomes a practice calling for the intervention of the law. 
But there is no way by which these frauds on the part of the custodians of the insurance fund can become a menace to society, except by provoking or seeming to justify such acts on the part of the insured as I have described, or by extending into a cycle of wild and fraudulent speculation in the formation of bogus companies. In connection with marine insurance, the latter is unlikely to happen. In other chapters, attention is given to several great epidemics of company promotion. It will be observed, however, that these mushroom concerns can only win success by operating among a large class of credulous people who will not resist chousing. Shipowners, charterers, and merchants are hardly of that kind. As a rule, they know how to make a bargain, and have money enough to command the assistance of lawyers and courts for its interpretation and the enforcement of its terms. In trading communities, which otherwise would be the favourite field of operation for the fraudulent insurer, those seeking insurance usually operate through some organisation, such as an exchange or chamber of commerce. However loose that organisation may be, even if it be but an assembling place, a Rialto, "where merchants most do congregate," exclusion from its precincts or a bad reputation among its habitués deprives the fraudulent operator of the chance to trade. There have been many frauds by custodians of the insurance fund; there have even been bogus marine insurance companies; but the harm is as nothing compared with the more extensive, more complex, and more heinous crimes of those who buy insurance. In any case, fraudulent refusal by the insurer to pay fair claims would hardly justify conspiracies to defraud and murder on the part of the insured.

Besides the wrongs committed by the insured and those committed by the insurer, directly against each other's interest, and, indirectly, against the interest of the public, there is an evil growing out of a combination of the two against others. 
Without an explanation of this point, some of the facts to which attention is directed would not be understood by the nontechnical reader. We find that, even in such a plain transaction as the exchange of so much grain for so much money, the tendency to represent things by tallies, documents, or acknowledgments develops, at length, a system of gambling. Every day men buy and sell wheat "on margin" who never saw a field of grain except from a car window, and who do not know the difference between wheat and barley at any stage of production or exchange. If the transaction " on margin " were called a wager on the price of wheat, the name would be much nearer the fact. From business to gambling in such a case is a much greater step than it is in a marine-insurance transaction. Very often, those who have no interest whatever in a ship have taken out "insurance" upon her, the insurer knowing, as a matter of fact, that the transaction was a mere bet. The effect of this is to give some people an interest in the loss of a ship. Even in these days of telepathy and psychic vibrations, it will hardly be said that the mere wish of gamblers on shore will wreck a vessel at sea. But if the interest of the gamblers in bringing about a wreck is only large enough they may take means, such, for instance, as the suborning of the master, to give their speculation an element of certainty.

The evil of this system is greatest, however, when part of the amount insured represents a bona fide interest. The real insurance then becomes a pretext, a veneer-what Josh Billings used to call "the Devil's putty and varnish"-for the wager. If a shipper represents that certain goods, worth $\$ I, 000$ are worth $\$ 10,000$, and succeeds, by deceiving the insurer, in getting policies to the latter amount, he is guilty of fraud. But if both parties know the value of the goods, and still the insurance is made for $\$ 10,000$, there is ten per cent. of business as an excuse for ninety per cent. of gambling. Real insurance would only make good any loss, but gambling insurance- 
which is a contradiction in terms, but all the plainer name for that reason, perhaps-pays the whole amount if the goods are lost. Without following the process by which such transactions became almost a part of the system of marine insurance, it may be said that in their full development they thrive under some condition in the policy by which the right and duty of the insurer to ascertain the amount of the loss and pay only that amount is foregone, and, conditionally upon the happening of the accident insured against, the policy is made a voucher for the whole amount insured.

If only the insurer and insured were affected by such transactions, we might tolerate them, as we tolerate, more or less, the gambling transactions of the wheat pit. But one of these marine insurance transactions is apt to work out like this : A vessel is in harbour ready to proceed upon what all recognise as, for her, a dangerous voyage. The owner, the charterer, the shipper of cargo, all overinsure their interests. Some repairs should be made, better sailors should be engaged, the cargo should be less and should be more carefully stowed. If these things are done, however, the cost will fall upon the insured, while the insurer will gain all the benefit, the risk being, in these matters, improved. If they are not done, the transaction will probably be more profitable for the insured, as the vessel is more likely to be lost. If we say that, in such a business, living men are used as mere counters for betting purposes, do we say anything but what is literally true? And if we say that such a business is demoralising, shocking, horrible, do we characterise it otherwise than fairly?

It will be shown, not merely that such transactions have taken place, but that they have been repeated so often as to call for legal repression. It will be shown, even, that the gamblers have, at times, successfully resisted attempts to put their business under the ban, and that the absurd and wicked system they represented has, at times, been so woven into the 
very web of trade that the separation of the two seemed impossible.

In this respect, as in others, modern conditions, at least in great part, make for honesty. The better laws of maritime nations, the improvements in insurance methods, the consolidation of sea-going commerce in the hands of capable men, all tend to differentiate business from gambling, and to discourage one and foster the other. There are elements of evil, however, which, in some countries, are not wholly overcome, and which may cause untold evil, if they are not watched and controlled.

In this chapter, I have attempted to suggest, rather than even take the space to state, the evils which arise from the abuse of marine insurance. In what follows, I intend to survey the whole field merely enough to show how widely abuses have prevailed, and how constantly they have attended the system. I shall then take an example that will show, more clearly than any general description could do, the effects of those abuses upon society in a trading nation, the difficulties that attend reform, and the effect of public opinion in bringing into existence a more wholesome condition of affairs. The example I take is the case of Great Britain during the rise of its maritime trade, culminating in an agitation which will be within the memory of many who are still in active life. 


\section{CHAPTER IV}

\section{MARINE INSURANCE-Continued}

Fraud Coeval with the System - Early Ordinances Designed to Check Abuses-Experience of Medieval Maritime Cities - State of the Law in England - Case of "the Noted Captain Codling" - Position of the Underwriters in Relation to the Reform of the Law.

IN Walford's Insurance Cyclopedia, a work of prodigious industry and erudition, which its author, Cornelius Walford, unfortunately, did not live to complete, it is stated that in the Institutes of Menu there are rules with regard to bottomry loans. This ancient Hindu book of laws has come down to us from a past so uncertain that scholars have spoken of it as being in existence thousands of years before our era; but the investigations of such thorough students of the East as Max Muiller show that the author or compiler of this code lived considerably less than two thousand years ago. Still, it would appear that, many centuries ago, in India, it was deemed necessary to lay down rules for the proper interpretation of bottomry bonds. Eight hundred years, at least, before our era, in Ancient Greece, the danger of fraud and misrepresentation in respect of bottomry loans was so great that the law made such frauds punishable with death. On the assumption that severe penalties repressed crime which could not otherwise be repressed, such a law was quite reasonable, for a few acts of bad faith in such transactions were enough to ruin a whole trade. Escape was so easy for the criminal that punishment was in the highest degree uncertain; and the lawmakers hoped-a hope which history has proven to be groundless in such cases 
-to make up by severity for what the law lacked in certainty of enforcement. The master of a vessel trading in the IFgean Sea in ancient times might borrow money to fit out his vessel or buy a cargo, pledging the property as security. But it would be easy for him to be "wrecked" in such a fashion that there would be large booty for the "wreckers," who might be people not wholly unknown to him, and not unwilling to share with him, in private, the property thus acquired.

Here and there in the broken records of the past that have come down to us, we find disjointed references to the frauds to which the finance of sea traders seems to have always been liable. Then comes the time, about the end of Roman domination, when trade seems to have degenerated into mere piracy; when the great city that had ruled and plundered the world for a thousand years could no longer maintain the monopoly of pillage which she had asserted under the sounding title of " the Roman peace." That the same evils as those indicated above continued to exist is quite probable; but even the most painstaking and erudite of those who have "pondered . . . over many a quaint and curious volume of forgotten lore" seem to have found but slight mention, if any, of the subject. With the growth of the Italian cities and those of Northern Europe, the development of the trade of the East, and the establishment of the Hanseatic League, we find not only bottomry, but also insurance, so-called, referred to in regulative laws and ordinances. The right of the ruling power, whether king, feudal lord, or city corporation, to make and enforce rules for individual guidance was less often questioned and more generally exercised than we have been accustomed to since the days of John Locke, Thomas Paine, and Jean Jacques Rousseau. We see to-day, in the writings of those who take Ruskin for their master, the desire expressed for the revival of those good old times when the man who made cloth of less than a certain width, or failed to exercise the grace of hospitality, 
or in any other way broke the well-meant rules laid down for the guidance of every member of the community, was severely punished. In those grandmotherly systems, we may feel assured, the fraudulent borrower upon a bottomry bond and the wrecker of vessels for insurance money were not forgotten. There was not a city or country carrying on a maritime trade that had not in its code of laws directions with regard to bottomry bonds, with penalties fixed for disobedience. In the code of the Hanseatic League, as revised from time to time, frauds of this kind were forbidden. Just what the frauds were that it was deemed necessary to repress, I do not pretend to be able to show specifically. But, in a most interesting work, The History of Lloyd's, by Frederick Martin, I find a quotation from the Recessus Hanse, or Hanseatic code, said to be of an early date,-and therefore, I suppose, of the opening years of the fourteenth century, - which gives an insight into some of them. It would appear, from the law as it is there given, that the master of a ship sometimes borrowed money on bottomry bond, the effect of his act being to pledge not only the parts of the vessel owned by himself, but also the cargo. Men might thus find their goods claimed by persons to whom they had given no interest in them, or thrown away by the master who had already realised upon them without their knowledge. The Recessus Hanse prohibited a master from raising money on the bottom even by pledging his own interest in the ship, without the knowledge of the freighters, and provided that, in any case, he should have no power to pledge more than his own interest. And, should he assume to pledge the freighters' property, the parties loaning the money were denied any claim except upon the property of the master himself. One exception to this is made; and that is, in case the master finds himself in a foreign port, with his vessel in need of repairs, and no other means of raising the money than by executing a bottomry bond. In that case he may pledge the 
cargo to raise what is necessary for the repairs, but no more. In case of malversation on his part in such a matter, the master was liable not merely to be fined, apparently, an unlimited amount, but to be put to death. All this is enacted, as the recital of this stern old law says, because "There occur every day more deceptions as regards bottomry, and there is not wanting even discovery of wicked crimes."

Mr. Martin, in the work just quoted, expresses a doubt that bottomry was practised from the time when it fell into disuse among the Greeks and Romans until the revival of commerce in the middle ages. It is stated that there is no mention of bottomry or of marine insurance in any form in the old maritime laws of Spain, Portugal, France, Italy, and neighbouring countries inhabited by Latin races. The first mention of the revived system of bottomry, according to this author, is in the laws of Wisby, one of the towns of the Baltic, at one time quite famous as a trade centre. For my part, I confess that it is easier for me to believe that the records are at fault than to believe that the trade of such great ports as Marseilles and Bordeaux managed to exist without some such means of protection. It is true that, under the feudal system, in its earlier development, there were trade organisations of cities and of separate callings, of which we learn but little in the history books, and which may have taken the place of marine insurance, as the guilds did the work now done by our fire-insurance companies. But, if bottomry disappeared with the power of ancient Rome, only to reappear with the growth of the trade which attended the development of Western Europe, it certainly is instructive to compare the two instances I have given, showing, as they do, that the frauds which, four hundred years before our era, were so serious as to call for the enactment of the Athenian law with its death-penalty, promptly came into existence with the second birth of the system a good deal more than a thousand years later. 
The invention of marine insurance, properly so-called, which the writers on the subject seem to refer to the latter part of the fourteenth century, complicated the situation, and led to new and special forms of chicanery. Under the laws of Barcelona, in force in 1435 , it was made an offence for a man to borrow on bottomry bond and then insure his vessel to her full value. This style of fraud, one would think, would be easily prevented by the parties refusing to advance money on a fully insured vessel, or to insure one on which a bottomry bond had been executed. Misrepresentation on such a matter would be the plainest kind of fraud, and, one would suppose, would be condemned under the laws of any trading city in an age when laws were many, and when the enforcement of individual honesty was regarded as a public duty. But it is difficult to understand many of the disjointed quotations given by the insurance writers on any other supposition than that the same vessel was both mortgaged and insured. For instance, in a curious old work called Panarithmalogia, written by one Leyburn in 1693 , are to be found some remarks on bottomry loans. After explaining that the loss of the ship discharges the debt, he proceeds :

Indeed, this causes many cheats; many men have brought their ships safe to the river's mouth and there have sunk them on purpose to avoid the payment of the money they owed at bottomry.

Unless a man had arranged to receive from the insurers indemnity for the loss of his vessel, it is hard to see how he could profit by such a trick. The bottomry business got into bad repute in England, if we may rely upon the statement of a correspondent of one of the weekly newspapers. During the South Sea Scheme inflation, among the many companies projected was one to make loans on bottomry bonds. A correspondent of Mist's Weekly Fournal, a respectable periodical, warning investors against the scheme, says: 
I need not tell you . . . how it has come to pass in trade, that when we know a master or captain of any ship has taken up money upon the bottom, no wise man will send goods on board that ship, nor any insurers underwrite upon her, except only goods bound to the East Indies.

-and why the exception we need not trouble now to inquire. But, if the facts were at all as represented by this correspondent, there must have been a parlous catalogue of crimes entered in the books of the recording angel against those masters and captains who had "taken up money upon the bottom."

But the crimes committed for insurances were not, by any means, confined to those who had borrowed money upon their vessels as well as effected insurances upon them. If insurance as we now have it was invented in the fourteenth century, it was not long in existence before it had brought into full fruition a very large crop of rascalities. In the laws of Barcelona, already referred to, we find provision made against even gambling insurances, - the insurance of ship or cargo by parties who had no possible interest in them. These sound old Mediterranean traders, whose liberties, unfortunately, were destroyed by the despots who destroyed Spain, at least diagnosed the disease truly, and did what they could to remove the cause of it. They sought in every way to prevent over insurance, knowing well that the reason why so many losses occurred was that it became more profitable for the owners to sell their property to the insurers through even a real loss at sea, than to complete a voyage. " In order," as they put it, " to extirpate all manner of frauds that may take place in effecting insurance on ships, great and small, and on merchandise," they decreed, among other things, that vessels owned and freighted by foreigners should not be insurable in Barcelona ; that foreign vessels freighted in Barcelona should be insurable for only half their value, and, in case of violation of this law, the insurances so effected were to be void, while the premiums paid for them 
were not recoverable. Gambling policies were prohibited; the insurer must " declare on oath that the insurances are real and not fictitious." To make this clearer, any words such as "value more or less," or any others designed to fix in advance the amount payable regardless of the actual value of the goods lost, or any terms waiving in advance of loss the question of ownership, were forbidden under severe penalties. On the other hand, it was provided that the insured must pay the premium, and pay it all, at the time of effecting the insurance; and the fact of payment must be stated on the policy itself, otherwise the insurance was not valid. The payments by the insurers, it was enacted, must be prompt and full; delay of no more than four months being allowed in the case of an ascertained loss, and six months in the case of a vessel which, though not reported lost, had not been heard from.

This tendency of insurers to refuse payment of even just losses is dealt with in a decree of the Grand Council of Venice, I468, in which it is spoken of as a "pernicious and detestable habit," which it certainly was. Disputes in insurance matters are, by this decree, referred to the arbitrament of a semi-official organisation of merchants.

To avoid confusion and uncertainty, and thus to minimise the opportunities for fraud, a number of Italian maritime cities resorted to a plan which has been extensively used in our own day in relation to fire insurance-that of having a prescribed form of policy. Under an enactment of the Council of Florence, in $\mathrm{I}_{523}$, a form of contract for marine insurance was adopted, and rates of premium fixed, no variation to be allowed except in special cases, and then only when authorised by a board of insurance deputies. Such a system would probably work well in a place with only a few classes of vessels and with trade covering only a few ports. With the march of invention and discovery, that condition of things would pass away; and, with a variety of risks offering, that port would 
flourish best which was without these cumbrous and hampering regulations.

These hard-and-fast laws must have seemed absolutely necessary, however, at a time when international understandings were the exception rather than the rule, and when trade was liable to interruption through war, much of it little better than what we now call piracy. Still, freedom, and not restriction, is the law of growth in trade, as in everything else; and of no trade is this more completely true than of that which follows the sea.

In this connection it is to be noted that the history of England, when contrasted with that of other countries, is a history of the assertion of individual liberty, as against the control of individuals by authority. Secret imprisonment was in use in other countries long after England had established the plan which has come down to us under the name of habeas corpus. In other countries, passports or safe-conducts were necessary, even in times of peace, long after one was free to enter, travel about in, or leave, England. On the whole, England has profited by this sturdy determination of her sons to maintain their individual liberty. But, in some cases, liberty has been allowed to run into license; that is to say, some have been allowed to claim more than their share, and the law which is supposed to maintain a condition of equality has been allowed to lapse into a condition of one-sidedness. There is, probably, no more striking instance of this than the case of marine insurance and the knavery to which it gave rise.

As it is my intention to take the case of England as an example, and to deal, in some detail, with the history of its marine insurance, a word in explanation of terms may be necessary, for the benefit of the reader who is not familiar with the technique of this business. "Lloyd's" has been more than once referred to. Every encyclopædia gives a sketch of the history of this institution. Originally, the name was that of a 
coffee-house in London. Like other places of the same kind, it soon became the resort of men of a particular class. In this case, the class attracted was of those financially interested in the merchant marine. One desiring insurance on vessel or cargo naturally turned to Lloyd's to meet those who would take his risk; and those who had money to place on such ventures as naturally sought the same resort in order to find customers. The system developed of posting in the coffee-house all sorts of information likely to be of interest to maritime adventurers. One list was made up of vessels on which insurance was desired, space being left under each proposition for the names of those who would take the risk or a share of it. Each insurer who wrote his name in this space became bound under a contract, the terms of which were well understood in the trade. Being, thus, "under-writers," they were naturally so called; and, with the elimination of the hyphen, they are so called to-day. The name, "underwriter" is often applied to insurers of every kind; and fairly enough, for the habitués of Lloyd's would, even from the first, insure anything, as they will now. But, strictly speaking, an underwriter is one who takes marine risks. Lloyd's, as all know, is now an immense corporation, the main centre of the merchant shipping of the world.

Although, as I have already shown, marine insurance was spoken of in the time of Elizabeth as an immemorial custom, yet, in England, according to the historian of Lloyd's, insurance frauds were, for long, not even classed among punishable crimes; and it was not until I702, the first year of Anne, that legal cognisance was taken of this class of offences. In that year, a statute was passed, as the result of strong feeling aroused among the mercantile community by the frequency of the frauds practised. But, owing to the form of the statute, it proved wholly inoperative. It was one of those cases, of which we see so many, even in our own time, of a law passed as the result of public agitation, but so craftily drawn as to leave room 
for escape for those who find obedience to its provisions inconvenient.

The explanation of the matter, in the case referred to, was this: The underwriters, wishing to put down frauds by which they suffered, sought the assistance of reputable shipowners, with a view to urging Parliament to pass the statute necessary for that purpose. The shipowners had their own troubles, in the form of difficulties in the way of punishing those who were guilty of carelessness or fraud in handling their property upon the high seas-masters and mariners. Underwriters and shipowners nominally joined forces; but the practical result showed that the kernel of the law was for the benefit of the shipowners, while the shell was carefully handed to the underwriters.

Affairs went on in this fashion for a quarter of a century longer. In 1723, when George I. was on the throne, with Walpole as leader of the Ministry, the underwriters succeeded in having a law passed which seemed to be wholly satisfactory. Under this statute, not only a "captain, master, officer, or mariner" who should wilfully cast away or destroy a vessel, or procure the same to be done, to the injury of underwriters, but also "any merchant or merchants who shall load goods thereon," or "any owner or owners of such ship or vessel," offending in like manner, should be accounted a felon and treated accordingly - which, in those times, meant the gallows.

Nothing could be plainer, one would think, than such a law; yet I think I am right in saying that, though fraud was so frequent that it became almost a recognised part of the system, and though masters who had thrown vessels away under instruction of their owners were hanged, no owner, however plain his complicity in such frauds, was ever punished as a criminal for his share in them. This was due partly to the difficulty of securing evidence under the statute, and partly to the confusing intricacies of the general law affecting the point. I have already spoken of the incomprehensible nature of marine 
insurance. Nowhere is this more clearly to be seen than in the proceedings instituted by English underwriters to protect their rights and to put the commerce of which their business was the bulwark and guardian upon a basis of common, everyday honesty, so far as it affected themselves. Reading between the lines of the very full record which is available, it is impossible to escape the conclusion that, during the time when the statute of 1723 remained nominally but not really the guarantee of the underwriters' rights, the wrecking of vessels for insurance was an immense trade, and one pursued, so far as the owners were concerned, with absolute impunity.

It seems difficult to understand, at first, how such evils could go on unchecked. But if we study commerce as it then was almost everywhere-and perhaps this applies with particular force to England-we shall see that it was pervaded by a spirit of gambling and knavery, of which these marine insurance frauds were but one manifestation. The South Sea Bubble in England and the Mississippi Scheme in France are explained by some historians on the theory that the people went temporarily mad from some inexplicable cause, and only recovered their sanity when their money was all gone. But the spirit that made these periods of delirium existed long before they began, and was by no means snuffed out by the failure of these great schemes. The difference between commerce and gambling is not over clear, even in our own day. At the time we are now considering, such a difference was hardly even suggested. New inventions, new colonies on virgin soil, new discoveries of people with whom-or, perhaps, in whom-to trade, had opened to the people a new world. The laws of that world they did not understand; but they revelled in its bounties and were infatuated with its chances. In fact, they went wrong through sheer exuberance of spirits, and ignorance.

The underwriters, in some cases where fraud was suspected, refused to pay, trusting to the statute of 1723 to make good 
their position. Even though the law was found to be of no effect in itself, it could be used as a sort of bugaboo to frighten some of the more timorous scoundrels with whom they had dealings. Certain legal trials, however, completely exposed the papery nature of this statute. It was found, owing to peculiarities of English maritime law, which it is not necessary to consider here, not only that owners could not be punished for attempting to defraud the underwriters, but that actually underwriters must pay losses unless the owner of the ship or cargo lost were shown to be guilty of fraud under the civil law.

Mr. Martin quotes a pamphlet of 1799 , - writer's name not given,- -declaring that one-third of the claims against underwriters were "mixed with fraud," and one-tenth of them "gross frauds." This we can believe when we consider the case of the brig Adventure, which was referred to in the evidence of Mr. Throckmorton, a leading underwriter, before the parliamentary committee that sat in 1810 to investigate the question of insurance frauds. The underwriters had made up their minds to prosecute when they found a case in which the evidence was clear. They found some cases that would have met all the requirements of a reasonable law and fair procedure; but the law was unreasonable, and the procedure, to put it mildly, intricate. However, the master of the Adventure acted as though determined that nothing should be lacking to make just such a case as the underwriters were waiting for.

The Adventure and her cargo were owned by Messrs. George Easterby and William Macfarlane, who seem to have been merchants in good standing and men of good reputation. But the property was greatly overinsured. The master, Captain William Codling, seems to have been a thick-headed old scoundrel, one who not only would "obey orders, if you break owners," but would follow instructions in dull, unthinking fashion, with stolid indifference even to his own fate. Leaving 
the Thames, he took the vessel to Yarmouth for a little more cargo and a great deal more insurance. The supercargo, being one who could see his way about, realised that disaster was intended to the vessel, and perhaps death to himself and the others aboard. So, when he set foot on the shore at Yarmouth, he refused to go aboard again. At a later stage of the voyage, the first mate left, having some regard for his own life. The Captain appears to have had very bad luck. The weather remained persistently fair, and so the ship could not well be "abandoned to the fury of the sea."

He hung about the shore, praying for foul weather, but none came. This was evidently a case for a man of determination and resource; and Captain William Codling rose grandly to the occasion. He ordered a keg of rum to be brought on deck, and invited all hands to partake of its contents. While the rest were thus convivially employed, he sent the first matewho had been a common sailor up to the time his wiser predecessor had left the gang-to scuttle the ship. A leak was made, but not large enough to suit the Captain; so he ordered the mate below again with a larger auger. Still the ship sank in but dilatory fashion; so Codling sent his man down again to complete the job with a hatchet. He completed it, and the Captain was gratified to see that she had not long to float.

By this time, the sun was rising upon a glassy sea. It happened to be Sunday morning, and the location of the ship a few miles off the coast at Brighton. Many people thus noticed the strange movements of the brig, which was evidently not sailing true, but yet had up no signals of distress. Some put out in small boats to investigate and, if necessary, offer assistance. But Captain Codling met his intending rescuers with curses and threats, and ordered them away from his property. No doubt he thought it most inconsiderate and impolite of them to interfere with a true-hearted British tar who was but trying to do his duty and earn an honest penny for those whose bread 
he ate. The people, of course, could do nothing; but a revenue cutter, attracted by the unusual spectacle, took the Adventure in tow, intending to beach her. She made water too fast, however, and sank while still about two miles from shore. Captain Codling and his crew went ashore in a boat and put up at a convenient inn. The owners, being informed of the "accident," came down to Brighton. Easterby not only called Codling "a damned fool," railing at him for having "made a stupid job of it," but pointed out, both in sorrow and in anger, how easily he might have done his work without attracting attention, by going nearer to the coast of France before scuttling the ship. Such a job, he declared, "had been done hundreds of times and had always succeeded."

Codling was arrested, and, after a long trial, condemned and hanged. But the owners of the vessel and cargo, though their guilt was glaringly plain, and though the verdict of the jury went against them, were not condemned by the judge, but were remanded, because of some merely technical point raised by their counsel. They were afterwards pardoned. It is not specifically stated in the narrative, but I suppose they were not able to consummate their fraud by compelling the underwriters to pay the amount of the insurance.

When such flagrant frauds as this could be carried on by "reputable" merchants, and only fail of success through the magnificent and persevering stupidity of a drunken old sea-dog of a captain, it is not possible to doubt that the thing had been done, as Easterby, who evidently had expert knowledge, said, "hundreds of times." The record of those crimes, could it be made up, would be a sickening one.

As a result of the agitation arising out of this Adventure case, the law was amended in 1803 , under Lord Ellenborough, so as to make it easier to convict fraudulent wreckers and their accomplices, and also to increase the responsibility of owners. Other similar attempts to improve the law were made 
afterwards, but with little practical result in the direction intended, as we shall see.

In this connection, and as bearing upon what is stated in the next two chapters, I desire to quote a few words from The History of Lloyd's, already referred to. Let it not be forgotten that Lloyd's is the institution in which are centralised the marine insurance interests of Great Britain, and, it might almost be said, of the world. The author says:

Many other attempts to prevent insurance frauds simply by penal enactments followed those of Lord Ellenborough, but they were more or less inefficacious. It was then that, gradually and slowly, the conviction came to underwriters that the less they depended upon the legal punishing of frauds and the more on their own vigilance to prevent them, the better it would be.

It has already been suggested that, as the profits of the insurer depend upon maintaining due proportion between the charge he makes for indemnity and the amount he is to pay for indemnity, the result may be attained by altering either factor. That is to say, if the insurer is not making a profit, he can change things to his own advantage either by decreasing losses or by raising rates. It has been stated also that it is not the business of the insurer to make conditions, but to accept them, and to provide, by the rates he charges, for the losses that occur under them. In this view of the case, while an underwriter in England might reasonably resist an attempt to defraud him-fraud not being one of the conditions of the contract with him-just as he would resist the effort of John Dawkins, alias the Artful Dodger, to pick his pocket, it was no part of his business, as an underwriter, to seek changes in the law; for that would mean, not an enforcement, but an alteration of the conditions of the contract. When, therefore, the underwriters of Lloyd's decided to accept a risk as they found it, including as part of it the existing law of England, and to charge ac- 
cordingly, they did exactly right. Their position was just, wise, and businesslike.

The effect of such action on the part of the insurers, as has already been stated, would be to allow any loss that might occur to fall upon the whole body of those insured by the underwriters who ran their business upon that principle-as it ought to do. If the insured, or any of them, did not like to continue paying for frauds, they could pursue either of alternative courses, - they could seek insurance elsewhere, or, by adding the cost of insurance, with other expenses, to the price of the goods, throw upon the general public the whole loss. If they took the former course, the matter and its results would be nobody's business but their own. If they took the latter course, it would be the right and duty of the public, as the aggrieved party, to cry out and demand reform.

But these things do not always work out in accordance with logic or sound business principles. Both the people and the underwriters are too apt to be misled. The public are prone to think that the underwriters are, in some way, specially interested and should be looked to to lead in the agitation for reform. The underwriters, as we have seen, are too apt to go beyond their proper sphere, and, instead of fixing the rate to the hazard, to attempt, by legislative changes, to conform the hazard to the rate. And when the public, in the exercise of their right, demand amendments of the statute law which will have the effect of disturbing the basis of existing insurance rates, the underwriters are too ready to resist those changes, instead of accepting them and rearranging their rates accordingly.

It is easy to understand that, say in 1870 , the British underwriters, traders, and public might be perfectly satisfied with conditions which, properly understood, would be seen to be anything but just, anything but sound and stable-underwriters and traders satisfied because the conditions caused them no 
loss, and the public satisfied because they were indifferent to or unconscious of loss. To so enlighten public opinion as to bring about dissatisfaction and, consequently, change, might be exceedingly annoying to those operating under the conditions as they existed in I870. If an agitation for improved conditions should arise, and if the underwriters should throw their influence into the scale against that agitation, they would be doing that which would make their business-whatever its advantages in other respects-a conspiracy against the public welfare. The immortal author of The Wealth of Nations makes the broad and sweeping assertion that men engaged in any trade never meet for any purpose, even for social converse, but they begin to conspire against the public. This is but too true; though, for the matter of that, it applies with equal force to kings and philosophers also. This far-reaching truth goes to teach us that we, the public, the common people, should insist upon being informed on all these matters that are of such living interest to us, and should watch with a jealous eye every movement of every body of traders, kings, philosophers, or others.

The historian of Lloyd's, I say, records a highly praiseworthy decision when he tells us that the underwriters determined to make their own rates and allow the people to make their own laws. Had the underwriters remained silent on the whole subject of the agitation for legislative changes, no word could have been said against them. Had they facilitated the investigation of the facts, and given the public the benefit of their expert knowledge, they would have laid the world under deep obligations to them. But, on the whole, they did neither. On the other hand, many of them opposed and hindered, and, for long, were helpful in defeating, one of the most beneficent and philanthropic agitations that even the country of Howard, Wilberforce, and Shaftesbury has ever known. 


\section{Marine Insurance}

To understand how, through insurance, abuses grow up that slaughter men and demoralise trade, and also to understand how those abuses are kept alive by the unfair and unwise use of their influence by those interested in insurance, it will be well for us to consider, as briefly as we may, the agitation for the amendment of the merchant shipping laws of Great Britain. This is the purpose of the next two chapters. 


\section{CHAPTER V}

\section{MARINE INSURANCE-Continued}

The Amendment of the British Merchant Shipping Laws a Subject of Keen Controversy-Large Number of Vessels "Missing" Attracts Attention - Loss of Life in "Missing" Vessels - What was Said by Apologists of the System-Evidence to Show that Care in Shipbuilding and Navigation Make for Safety.

THE subject upon which we are now about to enter brings

us not merely to modern, but to recent times; and the consideration of it plunges us into a controversy which is by no means settled-a controversy which adds to the intricacies of marine law and the mysteries of marine insurance all the difficulties of warring interests and strong emotions. I shall tell the story as I see it, giving authority for my statements where it seems necessary. At the same time, it is but fair to warn the reader that hardly a single statement of importance has been made in this controversy that has not been contradicted, explained, or offset by some counter statement.

The changes in public sentiment on this subject, and in the law relating to it, up to $187 \mathrm{I}$, I do not pretend to have followed with attention. It was stated, in the course of a debate in the British House of Commons in 1875 , that before 1839 the law was not in satisfactory form; but that in that year a change was made which had the effect of lessening the number of losses at sea. The same speaker declared, however, that, in I862, under the influence of the Free Trade idea, restrictions imposed in 1839 were removed, the power of the shipowners was increased while their responsibility was made less, the 
result being a marked increase in the loss of lives at sea. It is not necessary for our present purpose to seek to test the accuracy of that statement. A whole volume would have to be written if we attempted to follow the ups and downs of British legislation relating to the merchant marine. The student of the subject finds, however, that about thirty years ago this question of the safety of life and property at sea forced itself upon the attention of the British public; and that since then, with some lull and intermissions, it has been the subject of more or less marked public agitation.

The British merchant marine in 1870 included 26,376 vessels, manned by about 196,000 officers and men. Fourteen years later, the tonnage had about doubled, though the increased size of ships prevented the number of vessels growing in the same proportion. The number of people then employed had increased, according to the Government figures, to 220,000 , and, according to the shipowners, to 300,000 . In 1884 , it was estimated that Britain had fully half the sea-going tonnage of the world.

Maritime law is, in the main, fixed. The principles of the law applicable to ships and sailors in Britain to-day are the same as those of the laws of Ancient Rhodes. But each nation has its own peculiarities in the application of those principles. How the growth of British trade has been helped or hindered by her maritime laws is a fine question for the sociologist; but it is one which does not concern us now. I think it safe to say, however, that recent maritime law in Britain, in some respects, shows greater divergence from the main body of such laws than is to be seen in the maritime law of any other great country. In no respect is this divergence more remarkable than in those provisions of the British law relating to marine insurance. We have already seen how nations of ancient times and those of the middle ages had strict laws governing these transactions, while in England, for centuries, the parties were 
left to conduct their own business within the almost limitless scope of the general civil law. Even when attempts were made to regulate these matters, the attempts failed, as we have seen in the case of the laws passed about a hundred years ago. The effect of these laws was not to prevent wrong doing, but only to make known the forms to be observed by those who wished to do wrong. Changes in the law relating to marine insurance were made rather by decisions of the courts than by legislative amendments; and, with the law, the practice of the business was considerably modified.

Fortunately, there is an excellent summary of the changes in relation to marine insurance, up to, say, I885, contained in the report of the Royal Commission on Unseaworthy Ships presented in 1887 . In considering the history of the legislation agitated for, or enacted, from 1870 onward, it will be necessary to refer further to this Commission and its work, but I anticipate now to the extent of mentioning some of the more important features of their review of the condition of affairs.

It may be well to say, in the first place, that a Royal Commission collects information and offers suggestions for the Sovereign, that is, for the responsible Ministers who advise the Sovereign. Such a Commission is supposed to include in its membership men of experience who command public respect, men who are best qualified to elicit from witnesses the information those witnesses possess; and, to facilitate that work, the Commission is armed with all the powers of a court to compel witnesses. The whole realm is, as it were, thrown open to the inquisitors. The members of such a Commission may not do their whole duty; but the scope allowed makes it almost impossible for them to fail to elicit some information of value, while their standing makes their advice always worthy of attention. The Commission here referred to was proposed by Mr. Joseph Chamberlain, when he occupied the high and responsible position of President of the Board of Trade in the last administration 
of Mr. Gladstone. Mr. Chamberlain himself was appointed a member of the Commission, and took an active part in its work. The report was unanimous, so far as any points to which we need to refer are concerned.

From the report it is manifest that the shifting of financial responsibility from the shipowner to the insurer had gone on step by step, until a stage had been reached where the usage was clearly contrary to any sound or reasonable public policy. It had even gone beyond the mere shifting of responsibility; for the way was open to any sharp and unscrupulous owner to insure practically to any amount, regardless of the value of his own interest in the property. The one point that might be said to mark an exception to this rule was that, according to a canon of marine insurance, which, whether authorised by the statute or not, had all the force of law, losses of less than three per cent. of the amount insured could not be collected from the underwriter. This, however, while being a convenience to insurers, as saving them from the annoyance of petty or merely imaginary claims, was by no means a protection to the public interest; on the contrary, it was a source of grave danger. It gave the needy and greedy shipowner an interest in having the loss a great one; and there were reasons, as will be seen in a short time, why a total loss in mid-ocean was the ideal "accident" that could befall.

There are two points about the system here shown to exist which deserve special notice. In the first place, it involved the practical establishment, under authority of law, of wager policies, which were forbidden, as has been shown, by some of the oldest and purest maritime codes of the middle ages, and which were supposed to be contrary to the very genius of British law on the subject of insurance, as explained by Arnould and other authorities. The evil of this practice in relation to life insurance had already manifested itself in England, as we shall see when we take up the record of that branch of the 
business; and wager policies on lives had been forbidden under a law passed in the reign of George III. In the second place, this treatment of the ship-owner under the law and practice of insurance was vastly different from the treatment of the seaman. It is plain that the seaman had the same interest in his prospective wages that the owner had in the freight-that is, the payment for transporting the cargo-and the charterer had in profits. But the seaman was prohibited from insuring his prospective wages. And why? Because, having his wages assured to him regardless of the length of the voyage, it would be to his interest to terminate the voyage early, and, if necessary, to throw the ship away for that purpose. But, while the seaman might not insure his wages, the owner might insure those very wages for his own benefit, by merely following a certain prescribed course. $\mathrm{He}$ could insure the cost of the voyage, including the food and other supplies to be consumed on the voyage, the wages of seamen, and so on; and thus, if the voyage ended by the sinking of the ship one day after she started upon what was intended to be a six-months' voyage, the owner could collect from the underwriter not only the value of the ship, but also the wages he had not paid and the other expenses he had not incurred. There never was a more glaring case of varying the sauce according to the sex of the fowl. The seaman might not take a small bribe to throw away ship and cargo, but the owner might take a great bribe to throw away ship, cargo, and the seamen's lives as well.

So far was this system of insuring every conceivable interest carried that, to meet some cases which ordinary insurance did not cover-as, for instance, loss through legal damages incurred by colliding with and injuring another vessel-clubs were formed which were in effect mutual insurance companies, and of which many vessel-owners were members. Besides this, there grew up a system of giving what were called "honour policies," supposed to provide for some last-minute emergency, 
as, for instance, a charter on the very eve of sailing to call for a cargo at a given point, the freight on which it was thought desirable to insure. Of course, the honour policy was abused in many cases, as was everything else connected with the system.

The question once more arises: How could it be that an underwriter would venture his capital-for the business was carried on, to a very large extent, by individuals, through the agency of Lloyd's-upon ships and cargoes which there was such a great temptation to those in charge of them to throw away? Why did they allow over insurance? Why did not they inspect the property to learn its real value, and make due inquiry to learn the real interest in the property of the applicant for insurance? Broadly, the answer is given in the closing part of the previous chapter: the underwriters decided that, as the law stood it was easier to pay losses than to fight claimants, and so they paid losses and fixed charges accordingly. They ceased, at length, to inquire as to values and interests, and issued what is called a "valued policy," which is the opposite of an "open policy." Under the open policy, the underwriter covenants to make good the loss suffered by the insured in respect of the property covered-that is, the amount of loss was left to be determined by the value of the property and the insured's interest in it. But, in the case of the valued policy, the amount to be paid in case of a total loss was fixed in advance. These valued policies had been brought before the courts by underwriters who felt that they should not be called upon to make good a merely supposititious loss with good hard cash, but the decision was that the insured was entitled to his money unless fraud were established. Of course, it would be only in one case out of a thousand that fraud, no matter how clear to the ordinary mind, could be proven in legal form; and so it became the custom, there being practically no exception so far as cases involving these points were concerned, to pay all rather than fight any. 
One considering such a perfectly crazy fashion of conducting business would naturally expect it to lead straight and quickly to complete demoralisation. Nothing could prove more completely the general soundness of British sea-borne commerce than the fact that it could bear upon its body such a huge and virulent ulcer as this and still live and flourish. It is also another proof of the existence of a force which has been referred to by some economists, but of which not enough has been made, in my opinion, - the tendency toward honesty in trade, comparable with the tendency toward health in the human body. Chicanery may make individuals rich; but it is a mere quicksand, and no permanent trade can be founded upon it. In fact, fraud is one business and trade is another and wholly different business, and, where labour is highly specialised, it is impossible for a man to carry on the two at the same time. A large concern, going bona fide into the business of trading by sea, could not afford to divert its attention and complicate its operations by running some ships to carry cargoes and some to be thrown away for insurance.

Another force which prevented this system of fraud from spreading until it killed legitimate trade was-in my opinion - the directly acting force of public feeling. The loss of life at sea could not go on increasing without attracting attention among a maritime people like the English, practically everyone of whom had some near relative or intimate friend among those that go down to the sea in ships. And, unfortunately, under the conditions of modern navigation, it is not possible to throw away ships without drowning a large proportion of their crews. As has been suggested in a previous chapter, when a shipmaster of olden times desired to collect from his insurers for a "loss," he had a choice of many ways of doing it, none involving the loss of life on the part of the crew. Owing to the smallness of states and the lack of means of rapid communication, there were facilities for frauds of this kind that do 
not now exist. But, nowadays, a ship cannot get away from the telegraph except by extending her voyage to parts little frequented; and she must go where there is no trade whatever if she is to go beyond the reach of the fast mail. In fact, a vessel, if she floats at all, is under constant surveillance, not merely by owners and underwriters, but by all who are interested in the welfare of any soul aboard. If the owner is to get insurance money fraudulently, he cannot do it by practising any of the old tricks of the trade-the vessel must actually sink, if a fairly good job is to be made of it. For a perfectly workmanlike job, she should sink in mid-ocean. If the crew go with her, why, "dead men tell no tales"; and, if they escape, their evidence as to "rotten plates puttied up with tar," or overloading, or deliberate scuttling is without the support it might have if the hull were left anywhere where representatives of the law might see it.

The report of vessel after vessel " missing," "foundered at sea," " lost with all hands," attracted public attention in Great Britain. The people that had paid to free the slaves in their own dominions; that had sent missionaries to the ends of the earth to preach the gospel of peace and brotherhood; that had made the prisons such pleasant dwelling-places that one of their greatest philosophers actually expressed envy of some of their inmates-such a people were hardly likely to remain silent and inactive while they had evidence to show that murderous conspiracies were hatching against so large and so beloved a class as their sailors.

The discussion of the subject and the demand for reform took the shape of a public agitation soon after the close of the American War of the Rebellion, say late in the sixties. British shipping at that time found itself face to face with conditions vastly different from those which had existed up to that time. For reasons which it is not necessary to discuss here, the competition of American shipping fell off; while, on the 
other hand, the development of sea-borne China trade and other forms of activity greatly extended the sphere of British shipping. At the same time, the superiority of iron and steam over wood and sail had been made manifest, and the movement had gained full swing which soon divided the merchant fleet into new, rapid vessels, successful in the great through lines of trade, and the old-and growing older and no better-vessels, confined to what might be called the local business or business in mere byways of navigation.

It is one of the laws of trade that waste is the accompaniment of large profits. The man who works a rich gold mine throws away in the tailings what, afterwards, under more economical management, makes a second profitable mine. The British shipowners, carried away by the enthusiasm of wide demand and growing trade, had neither time nor inclination to think of the item of insurance; or, if they had, they economised by becoming their own insurers, wholly or partly, rather than by attempting the almost impossible task of rearranging a business whose ramifications extended, as did those of marine insurance, into the administration of a complex system of laws, the traditions of an ancient guild, and the discipline aboard every ship flying the British flag. As Mr. R. N. Dale, a leading underwriter, said, in giving evidence on one occasion, while it was "logically correct" that marine insurance should be a contract of indemnity, not one of profit, yet, "practically, I believe it is most difficult, if not impossible of attainment."

There was an additional reason why the British shipowner should slur over the effect of insurance in causing waste, and that was that, during the period now referred to, insurance rates did not increase. In fact, the evidence goes to show that they actually decreased for many years, up to the time of the last great investigation in 1884 . This may have been due, as was suggested at the time, to the large profits previously made by underwriters, and the competition of men in the business 
who operated on borrowed capital, and by methods not too careful or scrupulous. It was probably still more largely due to the greater safety of the new appliances of trade, the iron or steel steamer, which made the losses less on the whole, and, by the operation of the law of competition, forced rates downward But all this was quite compatible with a very large unnecessary loss. Moreover, as the safety of trade increased, and the losses paid to honest men grew less, the profits of the dishonest would be all the greater; for they would pay in somewhat less and take out a great deal more.

When people began to consider the case, the effect of insurance naturally attracted attention. Just as Kipling, with the poet's instinct for getting at the heart of things, saw that "the money paid at Lloyd's" was one of the main sources of danger, so the people saw that if a real reform was to be effected, it must be by a change in the methods of insurance. It is not surprising, therefore, that, in the several investigations that were ordered, the Commissions were specifically instructed to take into consideration the condition and results of marine insurance. But what is surprising is to find that even the leaders of the movement allowed themselves to be drawn away from this to the consideration of other points.

It surely does not require the sapience of a member of Parliament or of a leader in a great social movement to see that, if the owner or controller of property can make money by the destruction of that property, the only thing that can save the property from destruction is scruple or fear on the part of the owner or controller. It seems quite plain that, if men are paid to be dishonest, enough of them will be dishonest to earn at least a portion of the pay; if men are paid to be careless, they will be very careless. And, if men so placed must hire others to help them, those men will do the work their masters are paid for-and do it more boldly, completely, and with less scruple, probably-and will use the plant and tools 
best fitted for their work; and will, themselves, become, by natural selection and education, such men as are best suited for their job. To attempt to make the plant or tools such as will save, instead of destroying, property, or to complain about the workers and their methods-all this is mere folly, so long as the pay for carelessness and roguery is large and sure. In the records of the agitation for greater care of life at sea, at intervals, we find reference to the fact that, insurance being carried on as it was, even an honestly conducted voyage would be more profitable if it ended in wreck the day after it began than if cargo and crew were landed in safety. When this idea is struck, one naturally thinks, "At last, here is a man who sees the point; surely, he will insist upon it that, in some way,-by legislation, by preaching, organisation, somehow or other,-it shall be so arranged that this bribe shall no longer be held out to men to be dishonest and careless. But, straightway, we find this same man talking about the extent of freeboard, fastenings for hatches, qualifications of masters and mates, and so on, and so on,-things which would set themselves right at once, if only the influence which kept them wrong were removed.

Commerce, as we find it during this long agitation in Britain, is like a ship listed to one side by an abnormal weight. To hang weights over the upper side, to rearrange machinery, or re-educate the crew, would be mere folly. Let the weight be placed where it belongs, right over the keel, and she will right herself and keep right. Let the plain business rule be followed, that the man who has control shall suffer for his own crimes, follies, or mistakes, and not be able to shift the results to others, and the result will be that honest, sensible, and skilful men will go into business. This is not inconsistent with such a system of insurance as will enable a man to purchase indemnity for losses due to elements over which he can have no control; it is inconsistent, and ought to be so, only with men profiting by their own faults and at the expense of others. 
An illustration of this principle is furnished by the history of the port of Montreal. The losses of grain-laden ships from that port were sickening. There were wise and necessary rules laid down by the port authorities for the loading of ships. But the fine for noncompliance was only forty dollars. Vessel-owners could make more than that by bad loading; so they paid the fine as a matter of course and sent the ships to sea. In 1873, the Dominion of Canada passed a law increasing the fine to eight hundred dollars. There was no money then in bad loading, and bad loading stopped at once and completely. Mr.-Martell, the senior surveyor to Lloyd's, who stated these facts in I880, said that in the sevenyears' interval not a single grain-laden vessel from Montreal had foundered at sea.

During the agitation, many tables of figures were given, showing the number of lives lost within one period or another, and a great deal of declamation and logic-chopping was indulged in, based upon the theory that the figures could not, and the makers of them would not, lie. But Mr. T. H. Farrer, Parliamentary Secretary of the Board of Trade (afterwards Lord Farrer) stated before a commission of inquiry that these figures were to be read by every man in the light of the facts as he saw them, and that, otherwise, they were of little or no value. As already suggested, the British shipping-trade was in a state of transition and development, and there were a thousand and one circumstances that might be cited as the cause of greater or of less loss. For instance, it was found that there was a remarkable falling off in the loss of life for three years after 1883 . This was paraded by the friends of the regulative laws which had been passed shortly before as proof of the soundness of the position they had taken. But it was pointed out, as against this, that the laws to which credit was ascribed had been in force for years before that.

The best explanation of the lower death-rate among sailors 
at sea that could be given by those charged with the duty of understanding these matters was that the weather, during I884, I885, and I886, had been singularly favourable to navigation. But the Commission of $1884-87$, after considering this and other reasons, virtually rejects them all, but gives its own opinion that the public attention devoted to the matter in I 884 had had some effect, and that the depression in shipping, which began in I884, and which caused many inferior vessels to be laid up, would account for the rest. This example only goes to show how easy it is to juggle with figures in such a matter, and how utterly valueless such juggling is.

A shining example of such figure-play, and one with which we must deal more directly, was that indulged in by the apologists of the system which was on public trial. They admitted-of course, denial would have been worse than absurd -that vessels were lost at sea, and that many seamen were drowned in consequence. But they resorted at once to the favourite trick of those who would minimise the appearance of wrong, of calculating the losses on the basis of average. Even if there were losses, said these people, those losses were small in proportion to the number of men employed and to the number of losses known under any other system. By making a ratio of losses to the men employed, and further diluting that ratio by the increased number of voyages actually made by steamers as compared with the old sailing ships, and still further reducing it by the increased tonnage of vessels and freight-by such processes the percentage was figured down to an inconsiderable decimal. The argument was almost enough to convince the widow and orphans of a sailor that their weeping for a loved one who had been among the crew of a ship reported "missing" was a cruel wrong to the high-minded gentlemen who had made money out of the loss, and to their able statistical defenders. And when to this statistical argument was added the appeal that a great trade which had been 
built up, as was alleged, without public bounties, should not be interfered with to its destruction; and that the vast majority of shipowners, being honest, should not be ruined to punish or check a few black sheep in their flock; and, above all, that these things ought not to be done to please well-meaning but ignorant busybodies, and to further their untried and unworkable schemes-when all this was said, it can readily be imagined that steady-going, conservative business men of the British type were very apt to refuse to be stampeded into a programme of legislative experiments.

The fact remained, however, that gross, outrageous carelessness, or worse, did characterise the management of some British ships; the fact remained that the owners of these vessels made money through losses which were due to their own carelessness, or worse; the fact remained that, owing to this criminal carelessness, or worse, scores and hundreds, if not thousands, of men lost their lives. That people should begin to believe that the fine houses owned by shipowners, and the silks and jewels that bedecked their wives and daughters, were bought with the price of blood was not surprising. And when the shipowners declined to purge their flock of the "black sheep," who, according to their own admission, were to be found there; when underwriters said that insurance should be conducted on a basis that would make honesty the best policy in shipbuilding and navigation, but that such a thing was practically impossible-it is hardly to be wondered at that the people, being refused assistance by those who pretended to know the facts and to understand the problem, decided to work the reform themselves. And it is also not to be wondered at that, even with the best of intentions, they failed or did not wholly succeed in accomplishing what they had set themselves to do.

In the next chapter, in which an attempt is made to follow, generally, the course of this agitation, some considerations are suggested to support my opinion that the attempt to right this 
wrong did not wholly succeed, and also to give some reasons for failure.

Before leaving the branch of the subject with which we are now dealing, it may be well to give a few facts, as brought to light by the Royal Commissions of 1873 and $1884-87$ and other official inquiries, to show how clearly it was proven that seamen were murdered by the hundred for the insurance money on the ships they sailed in, and to give the reader some idea of the real cause of many and many a wreck which it has been our habit to ascribe complacently to "the act of God." It is true that the men who fell victims to this system were in great part low, drunken, ignorant, and disreputable men. But, as that true seer, John Ruskin, said, in speaking of just such people: "'They may be what you have said; but, if so, yet are they holier than we who have left them thus." Let the public mind be informed and the public conscience aroused on such a question as this, and difficulties will disappear before the public determination to right a great wrong; for that it is by no means at an end even in this day I shall give the reader reason to believe. We cannot control the elements; we cannot, whether on sea or land, prevent Death from seizing his victims where and when he will. But we can set right mere human institutions, mere trade methods, which have the effect of setting up in the sacred temple of Commerce bazaars in which the goods dealt in are fraud and murder. To make changes, and, if necessary, to stop trade until they are made, is no more to injure trade than to put a vessel in dry-dock and scrape the barnacles from her hull is to injure the vessel. But, even if trade must be hindered, better so than kill men; for trade was made for men and not men for trade.

One of the documents submitted to the Commission of 1873 was a memorandum on the subject of insurance by Mr. T. H. Farrer, already referred to. A man occupying such a position as he did, and presenting a document which was designed to 
guide the Government in framing and Parliament in passing legislation on the subject, would not venture to exaggerate or otherwise leave himself open to criticism or attack. The whole paper was a model of its kind, and would be well worth quoting in full, could space possibly be afforded. But here is one short extract, which is given as a fitting introduction to a statement of some of the facts brought out by these official inquiries:

No doubt in the case of the honest owner of a good ship there are opposing motives to carelessness or fraud. A ship may have for the shipowner something beyond her money value. The loss may be such as to interfere with his engagements, or his course of business, or his character. But the careful and honest shipowners are not the shipowners with whom we have to do here. Take the circumstances as they have recently happened. Of late years, the character of ships and the profits of trade have changed and fluctuated in a very remarkable manner. Wooden ships and sailing ships have been completely worthless and have again risen in value. Iron ships have been in great demand, whilst the conditions of building and loading them so as to insure safety have been imperfectly understood. Freights have been at times enormous, and have sunk again. At the same time, trade has been rapidly increasing and freights fluctuating. What a temptation to the needy or careless shipowner! He says : "There is a prospect of large gains. If the ship comes home, my profits will cover a large outlay on premiums; if not, I lose a questionable ship." Human nature, and especially commercial human nature, cannot resist such a temptation.

The Assistant Secretary of the Board of Trade, Mr. T. Gray, put in a table showing that, of 1095 wrecks, including collisions, officially inquired into from 1856 to 1872 , there were 60 , involving the loss of 86 lives, that were due to defects or faults in the ship, her equipment, the stowage of cargo, or ventilation; 7 II wrecks, with loss of 137 I lives, to neglect or bad navigation by master, crew, or pilot; and the remainder, I 42 wrecks, in which 983 lives were lost, to stress of weather, inevitable accident, or unknown causes.

Another table was put in by Mr. Farrer, showing in elaborate 
detail the loss of life from shipwreck at home or abroad, from I 867 to 1872 , exclusive of losses through wreck of fishing vessels or open boats, collisions (including collisions with ice), and fire. Of a total of 1394 ships wrecked, with the loss of I2,048 lives, only 163 lives are entered as having been lost through the wreck of "ships which there is any reason to believe were unseaworthy or defective in hull or equipments." This seems not so bad. But the "next line shows perfectly appalling figures. No less than I 169 lives were lost in 485 ships reported as "missing." As I understand it, a "missing" vessel is one that goes out of port and is never heard of againswallowed up by the sea with all hands, and lost to human ken as completely as if she had sailed over the edge of the world and dropped into space.

Mr. James O' Dowd, legal adviser to the Board of Trade, told the Commission of 1873 something about his efforts to bring to justice those who were guilty of sending unseaworthy ships to sea. He was not exactly what is known in the courts as a "willing witness" for those who were carrying on the agitation then in progress for better laws and stricter enforcement of them; for the agitators had called in question the good faith of himself and other officials, and had made unwarranted use of the expression of his (Mr. O'Dowd's) personal opinion, that "there were men who had suffered death on the gallows who deserved it less than some shipowners who sent unseaworthy ships to sea." In his evidence before the Commission, Mr. O'Dowd instanced the case of the Arctic, wrecked in October, 1860. She was a well-built iron ship, rigged, apparently, for steam or sail. She loaded partly at Hull and partly at Grimsby. When ready to sail, her cargo consisted of miscellaneous goods, mostly heavy, and her deck was so crowded that "there was not room for a seaman's foot upon the deck." Two witnesses "deposed to all the pumps having been covered by the bales; they could not get at them in case of emergency." Did 
the captain remonstrate? There was no evidence, said Mr. O'Dowd, to show that he did, "but you will gather from his statement that he was not at all satisfied." Mr. O'Dowd went on, "The important feature of the case is this, that the Arctic was insured to the amount of $£ \mathrm{I} 3,000$." The earnings of the voyage were not insured; but the shipowners, for a consideration, gave the owners of at least part of the cargo a guarantee that if any of the goods-cotton-had to be thrown overboard, the loss should fall upon the ship, unless the ship was stranded, sunk, or burnt. In other words, the captain knew that every bale of cotton thrown overboard meant a loss to the shipowners, while, if the whole ship were lost, they would get more than ship and cotton were worth. But, says Mr. O'Dowd, "If the cotton had been thrown overboard (in point of fact, the number of bales thrown overboard did not amount to more than five), there would have been a chance of saving the ship." The vessel thus crazily loaded carried passengers also. She was wrecked, and nineteen people lost their lives, the rest being saved by men in life-boats. The disaster occurred off the Danish coast. The officer before whom the case was tried decided that the loss of the vessel was due to the deck-load, for which the owners were responsible. The result was, of course-that the owners were hanged or sent to penitentiary for life? Well, not exactly; but part of the costs of the inquiry to the amount of $£$ roo was awarded against them, Mr. O'Dowd having applied for this to mark the court's "sense of the improper conduct of the owners of the ship." The owner at first refused to pay these costs, "but the pressure of a distress warrant brought him to his senses." But, "did the underwriters pay the policies without dispute? Yes." Mr. O'Dowd admitted that the owner might have been prosecuted for misdemeanour. He did not explain why this was not done; but he told of a case in which a vessel had been sent out "shamefully overladen," not by the owner, but by an agent, and in which 
steps were taken to prosecute the said agent. But that person, feeling, no doubt, that a stern and unbending judge might hold that, in sending sailors and, perhaps, passengers to an untimely and unmarked grave in order to make money by insurance, he had been guilty of "improper conduct," absconded.

It is hardly to be wondered at that the owner of the Arctic should refuse to pay fines, and that he should feel indignant at being thus singled out for prosecution which amounted to persecution. Mr. O'Dowd himself said:

Pending the inquiry, I had the curiosity to go to the dock to see whether the Arctic was a solitary case, and I regretted very much to see cases of parallel overloading in the docks. The bales of cotton were above the bulwarks in several instances that I saw, and they were covered with tarpauling. I do not know how any human being could work a ship when she was laden in that manner; he would have nothing to hold by, the slightest sea would wash him from his slippery footing. I only bring the case of the Arctic before the Commission as an illustration of the practice that was then rife in the great port of Hull, and which continued for several years afterwards, and I think is not altogether defunct at this day, though the overloading is not so gross as it was at that time.

Overloading, a "practice that was then rife," and underwriters paid the policies without dispute. And this, and worse, had been going on not only at Hull but at other ports for years and years. Is it any wonder that the owner of the Arctic felt that he was being robbed of $£ 100$ ? And is it any wonder that public indignation was aroused by this cold-blooded system of so much money for so many-more or less-human lives ?

This same Mr. O'Dowd-a public official, be it remembered -put in a paper on the subject of insurance, in the course of which he quotes from the evidence taken before a Committee of the House of Commons about 1860 , which, he said, "is as applicable now [1874] as then." One of the witnesses before that Committee, Lieut. Forest, R.N., being asked to what he 
attributed the increase of wrecks, said, "The primary cause I consider to be the system of sea insurance." And he said he had known vessels to be insured "without inquiry of any kind." Mr. John Anderson, Secretary to the Newcastle Insurance Institution, when asked if ships were insured at Lloyd's without a competent knowledge of the character of the vessel, said, "There are a great number of underwriters who have no competent knowledge on the subject." Another witness, whose evidence we must take on Mr. O'Dowd's recommendation, as no description of him is given, attributed the appointment of incompetent persons as masters of ships to the system of overinsurance. And, when asked if overinsurance was the practice, he said, "There is a large proportion of the mercantile navy that would scarcely be salable at any price whatever, which are sent to sea insured for many hundreds of pounds." "They are worth nothing more than the materials of the masts and sails, and, if stores were taken out of the hull, would not pay the expenses of breaking up." Henry Woodroffe, Secretary of the Seamen's Society of South Shields, said he knew that vessels were sailed after they should be broken up. "I know an instance," said he, "of a vessel that was lost in 1833 . I spoke to the master, a valued friend of mine, and I said to him as he was going away, 'Christopher, I really would not go on that ship'; he said, 'I have been ill, my wife is ill, and I have a small family; it is summer time, and I shall venture this voyage and no more.' She went to sea and was lost, and all hands perished." When asked if the insurance made the owner indifferent to the fate of such a vessel, the witness said, "I have the insurance club book; she was insured for $£ 2000$. I should have thought the man insane who had given $£ 400$ for her."

Before the Commission of $1884-87$ appeared Mr. Thomas Gray, Assistant Secretary of the Board of Trade, who put in a series of tables showing loss of life at sea. From these it ap- 
peared that in the nine years ending December, 1883 , there were 2608 wrecks, with the loss of 22,526 lives, the lost including 3109 passengers; and 1208 casualties less than wreck, entailing a loss of 2090 lives, including those of 283 passengers -or a total of 3816 casualties, loss of life 24,616 , the lost being 21,224 seamen and 3392 passengers. There was, as already mentioned, a decided decrease in the next triennial period, 1883-86, which fact was referred to in the final report of the Commission of $1884-87$.

Reports of courts of investigation are included in the report of this last-named Commission. Among the cases is that of the Mangerton, lost with all hands in January, 1882. According to the finding of the court, she was overladen, and her managing owner was held responsible for this state of affairs. She was insured for $£ 32,000$, which was more than she cost in the first place, and $£$ 10,000 above her value as she was when she sailed on what proved to be her last voyage. The managing owner, when asked why she was thus over-in sured, said the shares were selling at a price which would justify that valuation. In other words, she was worth that much because he could run her at a profit on that figure, and get back the whole capital if she were lost. A "vicious circle" never was more complete-the vessel was overinsured because she was overvalued, and she was overvalued because she could be overinsured. The Derbyshire was condemned by the court of inquiry (after a casualty in which one life was lost) as unseaworthy, ill-found, and too deeply laden. She was insured for $£^{12} 2,000$, valued at $£ 9600$, at a valuation for sale of partnership interest; but, according to the managing owner himself, she was not worth more than $£ 8000$ in the market. Half a dozen other cases are referred to in the report, being cases thought worthy of special attention because they had been instanced by Mr. Chamberlain in the House of Commons in support of his plea for a complete investigation with a view to 
legislative action. All these vessels were shown to have been overinsured, some of them to have been overladen, some "missing," so that no evidence could be had of the cause of their loss. One steamer, the Emily, was worth $£ 8000$, insured for $£ \mathrm{r} 4,000$. She was stranded. Her owner admitted that she had been stranded twice in the preceding year. For one of these disasters he received $£ 4500$, and for the other about $\$ 5000$. And the court of inquiry condemned the master and mate as "grievously at fault" and suspended the latter's certificate for six months-the owner going scot-free. Is it any wonder that it was an Englishman who wrote that rich song with the refrain, "To make the punishment fit the crime" ?

As against all these things, there is evidence that "the dangers of the deep" have been practically overcome by the progress of modern navigation. For instance, there was the evidence of Edward Ritherdon, whose duty it was for twentytwo years (following his father, who had been thirty-two years in the same service) to inspect vessels employed to carry government stores to the East Indies-"clothing, machinery, paper, and railway plant, and, I may say, almost every imaginable description of stores," as the official himself put it. $\mathrm{He}$ took no chances about a vessel. One must have a dictionary by him to read with complete intelligence the description of his inspection; but it suggests thoroughness even to one who cannot follow it in detail:

We have her in dry-dock, and examine her outside; re have all the ballast shifted. If she is a wooden ship we have listings cut out; if she is an iron ship we have a good many of the limbers up and some of the ceiling up. We examine the state of the rigging and also the masts and the outfit generally.

It was suggested to Mr. Ritherdon by one of the Commissioners that perhaps the registration of the vessel at Lloyd's helped him, but the answer was: "No, we do not recognise Lloyd's clas- 
sification at all. We say we would rather look for ourselves." He took the same position with regard to the other shipping registers, and without the slightest prejudice. "If I had a 5-6 vessel placed before me," he said, "and she seemed to be perfectly sound, I should take her. I should not care what class she was." He had certain powers as to cargo also, and he used them, fixing a load-line at his discretion for sailing ships, and otherwise directing both steamers and sailing ships as to cargo. Under this system about two hundred vessels a year, on an average, had been sent out during his own term of office. Some of these were wooden vessels, some iron; some steamers, some sailing vessels; some made the voyage by the Cape of Good Hope, and some went through the Suez Canal. And losses? Yes, there had been losses. There was the Sarah Sands-the famous troop-ship that was burnt in November, 1857-who does not remember her, and the iron discipline maintained, and the glorious heroism displayed by the troops; and how, in spite of fire, sea, and hurricane, they won out without the loss of a soul aboard?-and the Hindoo, dismasted in the Bay of Biscay. There had been these two casualties in twenty-two years. "Do you mean," asked the Chairman, "all these other vessels, averaging two hundred a year, arrived safely ?" "Yes," answered Edward Ritherdon, Surveyor of Shipping to the Secretary of State for India, "I am not aware of any loss at all." Ah, but how about the same vessels coming back? Edward Ritherdon had nothing to do with the vessels after they landed their out-bound cargo. But the freight rates paid for this gilt-edged service- "Are the freight rates rather high ?" asked one Commissioner. "No," was the answer, "we do not pay more freight, with all our terms and conditions, than an ordinary merchant will."

The case of a leading shipowner, a Mr. Richardson, was brought before the Commission by Mr. Fowler, stipendiary magistrate of Swansea, in this way: 
He [Mr. Richardson] owned, on the average, ten ships, which were regularly despatched on long voyages, chiefly round Cape Horn, and, allowing for two voyages a year, he must have completed some 500 to 700 voyages. It was his practice never to insure his vessels. In the course of his long experience, he never lost a vessel but one, and that upon a sunken rock which was not marked on the chart.

Another firm, that of George Thompson \& Co., of Aberdeen, owned from twenty to twenty-four vessels, which they used in trading to Australia, China, and India, and on which they employed on the average about $75^{\circ}$ seamen. They owned a three-quarters interest in these ships. In the case of the sailing ships, their interest was not insured, and in the case of the steamers, they took a risk of $£ 10,000$, "just to show our faith in the steamers," as they put it. There were only three casualties resulting in loss of life-the whole number of lives lost being twenty-one. Mr. Henderson, a member of the firm, told the Commission: "The principle upon which we work is that we are not fully insured, and I think that would be a very good principle for everyone else to adopt."

Many other instances equally striking might be quoted, but it is unnecessary. The experiences already given should be sufficient to show that, under proper conditions, travelling over the sea is at least as safe as walking the streets.

We have spent so much time in setting forth the problem with which the British people found themselves confronted when they planned to make more effective the vigil of the "sweet little cherub that sits up aloft, to keep watch o'er the life of poor Jack," that it will be necessary to make a separate chapter in which to trace in outline the progress of the agitation, the laws that were passed as a result of it, and some of their effects. 


\section{CHAPTER VI}

\section{MARINE INSURANCE-Concluded}

The British Agitation for Security of Life at Sea - Plimsoll, his Character and Work-Difficulties of the Situation and Excuses of those Interested - Amendments of the Law, Following Report of Royal Commission-The Plimsoll Load-line-The Commission of 1884 , its Good Proposals not Implemented Owing to Political UpheavalDoes the Slaughter of Sailors still Continue?

$\mathrm{T}$ HUS we see that the people of Great Britain, when they took in hand the reform of conditions for the benefit of the seamen, found themselves faced by a very awkward complication of problems. The overvaluation and overinsuring of ships meant simply this-that badly built and old ships had been afforded a special market with the underwriters; that is, while a vessel could not be sold for much as a vessel, she could be sold for a very large sum as the prime factor in a lucrative insurance loss. This, of course, had its effect upon the vessel market, and made old vessels sell for far more than they were worth according to any fair basis of valuation. Still, as the number of people who understood the method of sale to the underwriter or were base enough to avail themselves of it, was limited, the demand was a restricted one, and values in the open market did not reflect the values in the market of insurance and wreck. Old vessels were, in fact, counters in a gambling game. But, just as a poker check will not pass current outside the "house," or, if it does, must be heavily discounted, so ships would not sell in the open market for such sums as they could be insured for, or sold for in the speculative 
ring. We shall find the same curious inversion of values in relation to other branches of insurance also.

On the other hand, any law on the subject must be general in its application; and there was manifest danger that, if the shipping-trade were unduly hampered, it might decline, as had that of other countries when grandmotherly interference was attempted by their legislators. Even as a matter of philanthropy, it might be better to drown so many hundreds of seamen unnecessarily every year than to tie up the whole merchant fleet, and condemn all the sailors to idleness, and their families, possibly, to starvation. The problem was one calling for honest, cool discussion. Unfortunately, as Henry George puts it, "the tendency of conflict is toward extremes," and the discussion was not wholly honest, and often it was very far from being cool.

Everybody knows, who is old enough to remember or learned enough to have read this controversy, that the most prominent name in it was that of Samuel Plimsoll. Mr. Plimsoll was a member of the House of Commons, being one of the representatives of Derby. Readers of the chapter just preceding this will have noticed that, in the evidences given to prove that the evil we have been considering was a real and not an imaginary one, I have not quoted from Plimsoll or any of his. numerous friends or supporters. Plimsoll put himself on record to a sufficient extent and in a sufficient number of ways. to make the statements he presented easily available. I believe that, with comparatively few exceptions, Plimsoll was accurate in his statements of fact. Attempts were made, of course, to discredit him; but, in his replies, he was able to show good grounds for the version of the case given by him. Still, I confess that, in reading the history of this controversy, I have come to the conclusion that he was too strong in his likes and dislikes to be accepted as a trustworthy guide by one who wishes to be sure of his ground. One of the officials of 
the Board of Trade, in giving his evidence before the Commission of 1873 , declared that he would have no further confidential conversations with Mr. Plimsoll. He said, moreover, that, in his presence, Mr. Plimsoll had spoken of the Assistant Secretary of the Board of Trade as "Tommy Gray," and had declared, "Before the present year is out, I shall crush that fellow; a greater rascal does not walk on two legs." In the House of Commons, also, he called in question the honour of a shipowning fellow-member; and, though the latter gave, as it seems to me, a fair defence, and also demanded an investigation into his own conduct, Plimsoll, so far as I know, -and certainly in the debate I now refer to,- - neither apologised nor backed up the demand for the investigation.

The "Seamen's Friend," as Plimsoll has been called, did a work for Britain and the world, however, which marks him as one of the greatest of that long line of heroes in peaceful striving for justice and humanity of whom England has such reason to be proud. His very impetuousness, his very coarseness of fibre, if, as his opponents said, he had it, fitted him all the better for the work to which he was called. A man more given to refinements of reasoning, more apt to see, to count, to consider difficulties, would have turned aside from the task as a hopeless one, or would have vainly worn away his life in arguing with the British people, when what they needed first and most of all was to be roused. Plimsoll's dogmatism, his simple belief that all opposed to him, whatever reasons they might be able to present, were in league with the selfish and callous schemers whom he was exposing; his pugnacious disregard of obstacles of every kind, and his magnificent loyalty to the cause he had made his own-all these qualities were necessary in the man who would drag the wain of commerce out of the foul bog in which it was moving.

It was, in fact, through very excess of these qualities, and by a manifestation of them unparalleled in the history of Brit- 
ish legislation, that Plimsoll snatched a victory out of the very jaws of defeat. That story is hardly part of such a work as this, but, for the sake of the illustration, as showing what a devoted and determined man can do in these matters, a few words may be given to it.

A measure in which Plimsoll was interested, and which will be more particularly referred to in a short time, had dragged through a long session of Parliament, and the day of prorogation was near. Everybody but one man-Plimsoll himselfwas aware of the difficulties and dangers in the way, and many had sought to clog and impede the progress of the measure by proposing amendments which could not be dealt with in the time available. At length, the Premier-Disraeli, that master of the art of doing disagreeable things pleasantly-announced that the bill would have to be withdrawn, but that it would be introduced and pressed through next session. Others protested -and accepted the situation. But Plimsoll was of the spirit of Roderick Dhu- "He yields not, he, to man nor Fate." He protested; he spoke with bitterness of the "death-dealing volubility and hypocritical amendments" that had hampered the bill, and declared that ships passed from hand to handnone being voluntarily broken up-until they fell into the hands of greedy, heartless speculators, "ship-knackers"and he had heard a member of Parliament referred to as a ship-knacker. (The Standard Dictionary says: "Knacker, Eng. A dealer in and slaughterer of old, diseased, or disabled horses." Surely the sententiousness of trope could go no farther,- "ship-knacker" is a whole cinematograph view.)

This kind of language would never do. Mr. Plimsoll was called to order. The check only increased the impetuosity of his onward rush. In another minute he was declaring, in tones of thunder, and with blazing eyes, "I am determined to unmask the villains who send to death and destruction"- 
But here Mr. Speaker rose in all the majesty of wig and gown, and with the authority of a venerable office, to suggest that the honourable junior member for Derby, in using the word "villains," did not mean to refer to any fellow-members of the House of Commons. "I did, Sir," promptly replied the indignant Plimsoll, "and I do not mean to withdraw it." Nor did he withdraw it, even under threat of suspension. And when, at last, he was ejected from the chamber for his contumacy, his last words-and, no doubt, he shook his fist at some of the "ship-knackers" as he shouted them-were, "Do you know that thousands are dying for this?"

And when, a week later, calmer but no less determined, he apologised for his breach of decorum, he carefully explained that, while he was sorry he had behaved so badly, he would not abate by jot or tittle the statement of facts he had given. That very session, owing to the attention drawn to the case by Plimsoll's splendid defiance of authority, and the public feeling thereby aroused, a bill was passed embodying many of the reforms he desired.

Such a man is to be honoured. He had the imagination and the love of his fellows to show him that he would be bloodguilty if he allowed the existing system to continue, and the courage to declare himself plainly. But, when it comes to the gathering of facts, for my part, I would rather cull in the quiet recesses of the public documents than in the tempestuous fields of such a man's oratory.

For the account of the scene in the House of Commons-it occurred on the $22 \mathrm{~d}$ of July, I874-I have depended mainly upon "Hansard," the official report of the debates. But I would refer the reader also to chapter lxiii. of Justin McCarthy's A History of Our Own Times (vol. ii.) for the more graphic account of one who, if not an eye-witness, must have spoken with many who were. Mr. McCarthy gives also an excellent summary of Mr. Plimsoll's work and its results. I 
would ask the reader to note particularly these words and the connection in which they appear:

The Government afterward promised to supplement it by legislation, regulating in some way the system of maritime insurances, which they justly declared to be essential to any satisfactory and final settlement of the question. It is clear that, so long as the existing system of maritime insurance was allowed to prevail, the temptation to unscrupulous shipowners would continue to be almost irresistible, and that no legislation merely applying to the fabric of a ship could properly secure the lives of the seamen.

The agitation for improved conditions for seamen in which Mr. Plimsoll afterwards figured so prominently began late in the sixties. Its first tangible result was the passing of the Merchant Shipping Act of $187 \mathrm{I}$, under which a deserting seaman might, under some circumstances, plead the unseaworthiness of a ship as justification-for, be it understood, under the previously existing law, a seaman who had "signed articles," even under the influence of the drugged liquor of the crimpinghouse, had his choice of going in the ship or going to jail. The law of $187 \mathrm{I}$ also made it a misdemeanour to send an unseaworthy ship to sea. In the following year, the merchant shipping was put under the control of the Board of Trade, a government department, and the administration greatly simplified, giving the Government actual and not merely nominal control over the worst of the unseaworthy ships. Plimsoll and his friends, however, were far from being satisfied. They demanded not only better laws but better enforcement of the laws already enacted. Public sentiment was aroused and concentrated upon the point by a book, Our Seamen: An Appeal, written by Plimsoll, setting forth the condition of affairs. In this work, the righteously indignant friend of the sailors handled the shipowning interest without gloves. He also pointed out the effect that insurance had in relieving the owner even of the rottenest vessel from all danger of loss, and 
actually, even where no fraud was intended, in making a wreck more profitable than a safe and successful voyage.

Straightway a party grew up around the reformer, and a vigorous demand was made upon the Government not only to improve the condition of affairs, but to do it without loss of time. The answer of the shipowners and underwriters was divisible into two main pleas. The first was that Plimsoll had exaggerated, misrepresented, even lied about the facts; and the second was that there were difficulties in the way of conceding the demands made, which difficulties the Plimsollites evidently did not understand, and which could not be removed by mere public clamour, but must be given time and fair consideration.

As to the first, it was like the answer of the loafer accused of non-support, concerning whom his unfortunate wife testified in court that it was fifteen years since he had done any work"She 's lyin', yer onner; it 's on'y ten years since I done any work." The system, it would appear, had not been the cause of quite so many deaths or quite such outrageous villainy as Plimsoll would have the English people believe. But, assuming that they admitted what they did not deny, their case was bad enough so far as this point was concerned. As to the second point,-that there were difficulties in the way,-there was much truth in it. But mention of the fact would have come with much greater force, not to say anything about better grace, from other people. Ulness it were laid down as a working principle that murder and fraud and conspiracies to procure the same had been necessary, under existing circumstances, to British trade, then it was clear that the difficulties were purely artificial difficulties which, as the shipowners had accepted them, worked under them, and, in a sense, benefited by them, might fairly be said to be of their own making. On this point the underwriters had a right to point out that for years, even for generations, they had sought to put the sea- 
borne trade on an even keel, but had failed, and failed for the reason that the British public had been foolish enough and callous enough to take no interest in the matter. Unfortunately, many of the underwriters preferred to let their influence rest with that portion of the shipowning interest that simply opposed Plimsoll, hoping to beat back his reforms while proposing none of their own.

At any rate, Plimsoll's book marked the beginning of a new era. It was no longer a question of an arrangement between two warring trades, the shipowners and the underwriters. The great public, with little knowledge of, and no respect for, trade arrangements or professional traditions, but strong in the good old-fashioned notion that men are better than percentages of profit, took cognisance of the case, and demanded that British seamen should be given a fair chance in their battle with the sea, and not sent out in their coffins. That is the very word, by the way,- - coffin ships," these old hulks came to be called, and well did many of them deserve the name. The Board of Trade, under the constant and vigorous prodding of the agitators, used its powers in a manner exceedingly annoying to the shipowners and to nearly all concerned. According to the evidence of the Secretary of the Board of Trade, afterwards given, out of twenty-six vessels reported by Mr. Plimsoll as requiring investigation, only two were found unseaworthy, all the rest being fit to proceed upon their respective voyages, and three of them "about as fine ships as could be found." The Plimsollites would not accept the blame for their alleged mistakes, but, as already suggested, promptly gave it to be understood that the Board of Trade officials themselves were only half-hearted in this work. In the course of their operations, however, the officials found many unseaworthy ships. Of 443 vessels surveyed up to the end of 1874, no less than 404 were ordered to be repaired before being sent to sea, while 25 were found to be unfit to float at 
all, and were ordered to be broken up. Only i4 were found to be seaworthy.

This radical interference, it can well be understood, caused a great deal of annoyance by the element of uncertainty it introduced into the calculations of those engaged in an old-established trade. But there was a wide-open door of escape for the British shipowner. The Board of Trade could control only British vessels; and shipowners and their friends prophesied that the British merchantmen would be compelled to seek foreign registry. This actually took place in the case of 875 ships between January, 1873, and July, 1875 . Of course, the owners and their apologists declared that this was not the result of the fear that arises from a guilty conscience, but a manly determination to submit to no governmental interference in a purely private business. Still, the fact that, of these 875 ships put under the protection of foreign flags, the majority were wooden ships is worthy of note in this connection. The great depression of the British shipping-trade about 1850 was generally attributed to the competition of American ships, while the recovery from that depression was said to be due to the adoption in England of iron as a ship-building material. It is fair to suppose that, among these wooden ships that sought foreign registry were some survivals of the olden times-coffin ships of the deadliest.

The Government could not, if they would, wholly resist the popular demand for a change in the law; nor could they, by any means, devise a law which would not be open at least to the objection that, to cure the ills they had, the Government were flying to others that they knew not of. Out of this difficulty grew the Commission of 1873 . This was the only possible step, but the Government seemed honestly to believe that, this taken, they would see the way open for further progress.

But the very size, the imposing dignity, not to say grandeur, of a Royal Commission is almost sure, in such a case as this, to 
prevent the collection of one kind of information, notwithstanding the strong desire and the honest effort of the Commis. sion to collect it. There were two classes of people among whom the information was to be sought-virtually, the capitalist class and the labouring class. Of course, there were the officials, who might be regarded as a class by themselves; but all the information they had was already before the Government and Parliament, and no Royal Commission was necessary either to collect it or elucidate it. With the capitalists there was no difficulty: these men could speak on their own behalf, or they could hire lawyers and others to speak for them. And when they came, personally or by proxy, before the Commission, declaring their anxiety to make a frank and full statement of the case, it was not easy to do otherwise than take their statements as they made them. Even though the members of the Commission might think that a certain shipowning witness deserved the gallows as a murderer-as the official, O'Dowd, referred to in the last chapter, had suggested some shipowners did-they could not very well assume the position of prosecuting counsel and prove his guilt. Besides, if a shipowner had a flaw in his record, he would be apt to cling closely to the shipowners' society of which he happened to be a member, and to urge that the most severely virtuous and respectable of his fellow-members should be sent to speak on behalf of the whole body. The new law, moreover,- - passed, as already stated, in 1871-72, - was too new to have accumulated many cases of outrageous villainy; and, except in such cases, the officials or any others would not care to speak too freely, - for why should an official wreck his own usefulness by laying himself open to the charge of partisanship?-while, as to any cases under the old law, the natural answer would be that Parliament had already reformed old conditions.

On the other hand, how could the labouring class make themselves heard? They were poor men, many of them inefficient 
in their trade, - for good sailors found good ships and had no complaint to make,-many of them drunken, many of them criminal; - in any case, for reasons of their own, more ready to face death and hell in a rotten ship than a keel-hauling by gentlemen whom they had been taught to regard as their superiors and who were trained in the art of cross-examination. Moreover, they were not organised, at least not efficiently, for this purpose. Even the officers of their little societies, coming before a body made up of royal princes, privy councillors, high officials, members of Parliament, and millionaires, would feel themselves at a disadvantage, and either they would fail to make themselves understood, or, if they had self-assurance to "say their say," would almost certainly offend-and so injure their own cause-by their presumption and lack of knowledge of many important facts bearing on the question.

In fact, it was a case in court between a master of legal oratory and a man almost completely inarticulate. As might have been expected, the Commission got comparatively little of the information it really desired, or should have desired. And the plentiful lack of knowledge of the Commissionerswhich, as the subject was highly technical, can hardly be wondered at, for even a prince or an admiral can hardly know everything-showed itself in their reports. Being unable to finish their labours in the time desired, and, perhaps, urged by friends of the Government to do something to quiet public clamour, the Commission first issued an interim report, in which were described, with considerable elaboration, some of the many difficulties that existed in the way of every reform proposed. They were completely misled, at first, into taking up the question of the efficiency of seamen as a possible explanation of the loss of ships. The owners strongly contended that British seamen were deteriorating, and proposed all sorts of fanciful schemes of improvement. The Commission, following the suggestion, announced the sapient opinion that "the 
mismanagement and negligence of sailors are not less disastrous than the carelessness of shipowners," and proposed certain remedies in the way of licensing sailors' boarding-houses, certifying the competence of sailors, putting down crimping, and so on; but, even on these points, desired further time to ascertain the opinion of the seamen themselves.

This distinction between "seaworthiness" as a quality of the hull of the vessel and the loading and handling of the vessel, seems to have been continued ever since. It will be found to be made in the figures given in the previous chapter, where a few wrecks are attributed to the character of the ship, and many to the mistakes or neglect of the crew. The verdicts of courts of law, also, speak of ships as "seaworthy" yet "overloaded." This arbitrary and - as used - absurd distinction served well the purposes of the shipowners, who were glad, as employers generally are, to excuse themselves by throwing blame upon their employees. The excuse made in this case would have been a sound one, perhaps, for an individual; but it could not be sound as applied to a system. If capable men are not, as a rule, employed, it can only be because wages and other conditions are not such as to attract capable men; and, if an employer receives into his service men whom he has reason to believe inefficient, that fact, instead of being an excuse, is an aggravation of the offence.

The same distinction already referred to appears in the final report of this Commission; for, in one of the first paragraphs, the fact is emphasised that a large proportion of the casualties at sea are to be ascribed to "preventible causes other than the faulty construction, the insufficient repair and the overloading of ships." And, to illustrate this, the Commissioners quote, but without wholly endorsing them, figures to show that, in seventeen years, while comparatively few ships were known to have been lost from defects in the vessel or in the stowage, a great many were lost from neglect or bad navigation. At the 
same time, in dealing with marine insurance, the commissioners say that the system, while it "protects shipowners against losses which would otherwise be ruinous," yet it also "tends to render them less careful in the management of their ships." The Commissioners also say that while the contract of marine insurance is, properly, a contract of indemnity, "yet the law has allowed a considerable deviation from this fundamental principle." They find the case, evidently, almost a hopeless one. Though they make some milk-and-watery suggestions of changes as to valued policies, and so on, they point out diffculties in every direction, and say:

A complete and thorough revision of our law relating to marine insurance is, however, a task of equal importance, difficulty, and delicacy, requiring evidence of an extensive character and necessitating a very lengthy and careful investigation, and it touches directly on so many subjects unconnected with the security of life at sea, on which it has only an indirect and somewhat remote bearing, that we do not think it properly falls within the scope of our commission.

The italics are mine. How a body of men, so wise as to see the difficulties involved and the necessity of proceeding with the utmost care, could be so hopelessly blind to the truth as to think that a system that "tends to render them (the shipowners) less careful in the management of their ships" had "only an indirect and somewhat remote bearing" upon the safety of life at sea must be beyond ordinary comprehension. And when the Queen's Commissioners could show such wisdom and such hopeless, childish folly in the same sentence, it may be taken as a matter of course that the great, clumsyminded public failed to grasp the issue with skill. Wellmeaning, but clamorous, impatient, and mistaken, they drove Parliament into a course far less desirable than that which might have been chosen had more time been allowed for consideration of the case.

It was as a result of the report of the Commission, in 1875 , 
that the Government, under Disraeli's leadership, introduced a bill to amend the Merchant Shipping Act. It reflected the report, and dealt with four subjects-discipline, the safety of vessels, inquiries into casualties, and training boys for the service. The statement of these heads explains them sufficiently for our present purpose, except in the case of the safety of vessels. As to this point, the Government, in introducing the bill, declared against compulsory inspection of all ships. "We decline altogether," said their spokesman, "to certify the whole mercantile navy." The object sought was to make clear the responsibility of shipowners, and to afford means of fixing that responsibility and punishing those found guilty. It was, in fact, a free-trade bill, modified by such paternalism as had already been forced upon the Government by public opinion and shown in the already-extended powers of the Board of Trade. The justification for the refusal to "certify the whole mercantile navy" was that to extend the Government's power and responsibility would weaken those of the shipowner, who, after all, must control the ship, directly when she was in harbour, and indirectly when she was at sea; and that to interfere with the shipowner in the control of the ship was to cause confusion and to increase, not lessen, danger. This was a sound principle, and was in accord with all that had ever been learned of the best means of protecting life at sea, as shown by the autocratic power given the captain of a ship. But it rested upon a deeper principle-that the man who has power and responsibility shall also have an interest in the prosperity of the voyage. If, by a secret bargain, the shipowner could gain an interest in wrecking the vessel, the whole principle of power and responsibility would be inoperative, or rather, it would operate in the wrong way. On the Government's own reasoning this was the point to be guarded. Either they conceded too much, or they withheld too much.

Plimsoll was dissatisfied, of course. He was splendidly con- 
sistent in avoiding all discussion based upon principle and hemmed in by rules of logic. What he wanted was some practical result. He probably could not have shown where the Government's reasoning was at fault-at any rate, he did not try. But he did show how easy it would be for the "villains" whom he was denouncing to make the fearsome-looking law quite harmless so far as they were concerned. He pointed out that the real owner of a coffin ship had a businesslike fashion of avoiding responsibility by putting forward some man of straw as registered owner, a man who could not pay fines, and who would take a term in jail as part of his contract-a sort of "jail editor" for the ship, to borrow a simile from modern journalism. Plimsoll declared for an Alexandrian policy. $\mathrm{He}$ would cut the Gordian knot by increasing the inquisitorial powers of the Board of Trade and making them such that the officials should have no excuse for not doing the business. His facts were right, but the action he proposed was childish, as are so many of the proposed actions of those who brag of their refusal to use their reason by calling themselves "practical " men.

As already related, the Government's measure, mild as it was, was clogged, hampered, obstructed, partly by foolish reformers who had not taken to heart the homely proverb about the half-loaf, but mainly by interested parties who were simply opposed to change. At length, the Prime Minister announced that the measure would be withdrawn for that session. Plimsoll had been a marvel of patience during the whole tedious summer. Even according to his opponents, his conduct had been that of a man anxious to be pleased and ready to accept anything that at all approached his ideal. Considering the emotional and impatient element of which he had become the leader, and his own keen realisation of the fact that every day's delay meant death to poor unfortunates for whose fate he felt sorrow which was little short of anguish, his self-control is one of his greatest claims to our veneration. 
But when he felt the ground, as it were, sinking under him, he gave forth his hysterical shriek of surprise and indignation, as already related. And, by so doing, he worked a miracle. He evoked an answering roar from the people. It did not need the keen ear of Disraeli to discern in that roar a note of determination, that note that none but fools masquerading as statesmen have ever needed to hear twice. A bill even more radical than that which had been withdrawn was hastily introduced, and pressed through Parliament with a minimum of discussion. It was confessedly a "stop-gap" measure, and was intended to hold only until Parliament could reassemble and deal with the question more deliberately.

In 1876 , the permanent act was passed. It made clearer the responsibility of the shipowner to the seaman for the seaworthiness of the vessel and for proper loading; increased the powers, and also the responsibilities to falsely accused shipowners, of the Board of Trade; and made better provision for the investigation of wrecks. In subsequent years, provision was made for the regulation of grain cargoes and deck-loads. The Board of Trade, also, by authority of one of the statutes, afterwards adopted a load-line system under which the depth to which a vessel might be loaded was plainly marked upon her hull. These changes were a succession of triumphs for the Plimsollites. The mark upon the hull is still known as the "Plimsoll load-line." All authorities seem to agree that it has done a great deal of good and little or no harm. This may be perfectly true; I take the liberty of doubting it,-but it is not desirable to discuss these details here.

Since that time, the powers of the Board of Trade, by the accretion natural in such cases, seem to have grown greater and to be exercised with greater strictness. But no first-class legislation dealing with this subject has since been passed. Bills have been introduced to limit insurance to an indemnity; but the difficulties in the way, the claims of other matters upon 
the time of Parliament, and, above all, the turning away of popular attention from this subject have made it impossible to pass them in the form desired. There is reason to believe that, with the passing of the old wooden vessels and the increased strictness of official inspection, the most glaring and outrageous methods of murder for insurance money have come to an end. That this was not the result of the legislation passed, so much as it was of the calling of public attention to the matter, is shown by the fact that, in 1884 , the enormous loss of life at sea again demanded attention, and led to the appointment in that year of another Royal Commission, which has already been referred to as the Commission of r884-87.

The report of this Commission is in two parts, an interim report made in July, 1885 , which is merely a volume of evidence (House of Lords Papers, 1884-85, vol. 1.), and the final report, made in August, r887 (House of Lords Papers, 1887, vol. lvi.). This latter volume, particularly, is a perfect mine of information, and has been quoted frequently in dealing with this subject of marine insurance. The section headed, "Responsibility of Shipowners under the Law of Insurance," is a particularly able presentation of the case. After stating the arguments, the Commissioners say:

The consideration of these arguments leads us to think that no measure could be so fruitful of good to the safety of life and property at sea as one which would compel every shipowner to have some share in the risks which his vessel runs. . . . The state of the law which permits profit to result to the shipowner from loss accompanied by loss of life cannot be considered as otherwise than scandalous.

Acting on this idea, they propose,-

an effort . . . to reverse the altered practice of shipowners in late years; with the object of securing that shipowners shall bear some share in the pecuniary consequences of every casualty which may occur.

Nothing could better show the clear-sightedness and ability 
of the Commissioners than these words, unless it be the sentence that immediately follows:

The process must necessarily be a cautious and tentative one, not interfering too hastily with the established practice of a great trade, and not handicapping too heavily men of small capital as compared with shipowners or companies of large capital.

To this end, the Commissioners propose amendments to the law which, on the whole, seem to have been well considered. They are all in the line suggested by the report, the object sought being to make the shipowner his own insurer to a certain extent. One proposal is that honour policies shall be abolished, and the proposal is in a form that means exactly what it says. Under the law as suggested, not only would an honour policy be void, and not only would the parties to it be liable to legal punishment, but all legitimate policies on the same property would be void. This would be a drastic law indeed, and one to which many objections might be urged; but it would, at least, have the merit of actually accomplishing the thing desired, notwithstanding the secrecy and collusion to which such transactions as these honour policies lend themselves. In a country where lotteries, wager policies, and public gaming are forbidden, such a law is honest, reasonable, and consistent. Another most wise proposal is to allow the officer inquiring into a case of wreck to call for full particulars of insurance on vessel, freight, or cargo. The advantage of this will be seen at a glance. To inquire into a wreck without ascertaining the insurance is the same as to inquire into a case of death by wilful violence without ascertaining whether the deceased had or had not valuables upon his person at the time of the assault.

But, between the time of the appointment of the Commission and that of the presentation of its report, came one of the greatest convulsions known to party politics. The man who 
had proposed the Commission, and whose spirit seems to have dominated its operations, the Right Honourable Joseph Chamberlain, became the leader-in view of the tremendous power the man has shown, it is not unfair to acclaim him leader even in the company of Bright and Hartington-of the revolt against Gladstone on the question of Home Rule for Ireland. Since that time, great political events have followed one another rapidly, and this question of the seaworthiness of ships has failed to attract the attention necessary to the production of legislation of great practical importance.

I confess that when, for the purpose of this work, I entered upon the detailed study of this question of the baleful influence of marine insurance, I thought to find a closed chapter of history, a trade from which, so far as Great Britain was concerned, the evil had been eliminated and nothing but the good remained. It is with regret that I am compelled to believe that, however much has been accomplished, a great deal still remains for the reformer to do. Whether it is that the evil never was put down, or whether it is that we have a recrudescence of morbidity, I do not know. But the fact seems to be that vessels are still overinsured, and are "lost with all hands" because of that insurance. I refer the reader to an article in the Forum of November, 1899, by Captain A. G. Froud, Secretary of the Shipmasters' Society of London, an article which, to my mind, is nothing less than startling. Captain Froud cites the loss of ten steamers about the time of the heavy gales of January and February, I899. These vessels were not stranded or wrecked in the ordinary sense; they were lost, and no trace of them has been found, up to the time when Captain Froud wrote; that is to say, the crews of these vessels went down in mid-Atlantic, in one of the most-frequented parts of the ocean. The loss or even detention of a great passenger ship is enough to set the whole civilised world at attention. But a tramp steamer may go down without the general public being any the 
wiser, the loss and suffering being confined to those who have friends aboard.

Captain Froud tells us that the tendency now is to reduce the weight of steamers, steel being substituted for iron for that reason, and other economies of weight being effected. The result, he says, is to reduce the rigidity of the vessel, and so make her less able to resist the awful strain to which she is subjected-now from the weight of an enormous cargo, and again from the pounding of the sea and the power of the machinery, which is not always governable, when she is in ballast. There are, he says, "hundreds of steamers afloat in all parts of the world, which are not fit to undertake transoceanic passages in ballast; owing to their lightness and consequent small displacement, their great height above the water line, and the imperfect immersion of their screws." The risk to life, he adds, is "positively appalling." This, he points out, is not due to overloading, but to light loading; and he says that a resolution was introduced lately in the House of Lords to make a two-thirds immersion of the propeller compulsory, but it was not carried. He gives some horrifying details of the behaviour of these iron sea-monsters while rolling and pounding, and, worse than all, when the whirling propeller is suddenly heaved free of the water. Sometimes food cannot be cooked, sleep is not to be had, boilers cannot be fed, and the man who loses hold upon whatever he may have clung to will be thrown across the ship and injured or killed. He complains also of undermanning and bad loading, giving some instances of the latter which would lead one to believe that the people guilty of tempting Providence in this way were plain, common, everyday lunatics. The public are told, says Captain Froud, that losses are unavoidable, and they do not understand that "the majority of accidents are due to preventable causes." $\mathrm{He}$ believes that ships can be built on good plans, of good material, and by good workmen; and can be so laden as to ensure 
freedom from loss by storm, save under highly exceptional circumstances.

As a shipmaster and officer of a shipmasters' society, Captain Froud naturally excuses his own class for allowing overloading and these other dangerous things. And when he shows how completely the master is under the control of the shipowner and the charterer, who generally work together, his excuse must be taken as a good one. But here is the first and main point he makes when he comes to deal with the causes of these evils:

A good deal of the recklessness and apathy shown by shipowners and speculators is to be accounted for by the possibility of insuring in full against loss of ship, cargo, and even unearned freight. Indeed, unlimited insurance has unquestionably done much toward cheapening life upon the ocean.

Again, he says:

It has been frequently suggested that the underwriters and insurance companies who undertake risks upon vessels should take some step to introduce improvements. This is purely visionary. It is quite beyond the province of such people to advise, or to control, the working of ships. The underwriter insures ship in order to make a profit. He summarises his losses, from all causes, and from the result deduces a premium by the charging of which he will be able to leave for himself a margin of profit. If for any reason whatsoever the proportion of loss increases, the premiums charged by him are raised proportionately. As a matter of fact, they are now constantly increasing.

He closes with a demand for legislation to check the present waste of life and property. At the same time, it is notable that, in the course of his article, he finds fault with the composition of the commissions and committees of investigation that have reported to Parliament upon the subject. The members of these courts of investigation, he says, largely belong to the shipowning class and its following; and experts summoned fear to give expression to opinions antagonistic to the interest of those who give them employment; and, of those who have 
spoken out honestly, many have been boycotted. I had formed a different opinion, at least of the Commission of 1884-87, and should much dislike to change it, for it is pleasant to believe in the uprightness and public spirit of those charged with the management of public affairs. I cannot pretend to such a knowledge of the facts as would justify me in disputing what Captain Froud says; but I take the liberty of pointing out that, as Secretary of the Shipmasters' Association, his evidence may be regarded as $e x$ parte, and so not wholly conclusive. I confess that, if I were so fully convinced as he seems to be that legislation in the past, notwithstanding the herculean efforts made to make it adequate and keep it working right, had been wrong from its very initial stage-that of inquiry into the facts-I should not call for further law-making with the confidence which he seems to have in its effects. What he says would go far to convince me that something else, or at least something more, than legislation was necessary.

I have quoted Captain Froud's article, not as proof that insurance still sends hundreds or thousands of brave men to a wholly unnecessary death upon the sea, but as evidence which must make us fear that the sacrifices which have been going on all these weary years have not yet ceased. If I had the power, I would arouse the world to a sense of its responsibility, and would so turn upon this traffic the light of indignant public opinion that none but men who hate gain got through the injury of others would ever dare to send ships to sea again.

If the reader of these lines ever feels called upon to join his fellow-Christians in that sweetest and most solemn of prayersongs, the burden of which is

$O$ hear us when we cry to Thee

For those in peril on the sea!

let him remember that not wind and waves, not fire and sunken rocks threaten those whose lives he prays for. Those 
at sea, in our day, are in no more peril than are those ashore who pray for them, except for one thing; and for that one thing he who prays is himself primarily responsible. Let the Christian make good his prayer by demanding, as a Christian and a citizen, that merely artificial dangers shall be done away with. Then, and then only, according to his own reasoning, can he consistently and with good effect plead with the Maker of winds and waters for safety for those he loves.

But, in one sense, even the loss of life is not the worst feature of the case. This, we proudly say, is an age of trade and of advancement in the ways of trade. Nothing could be more important for the development of trade than improvement in our ships and our way of handling them. Yet here we see a force at work which gives not merely an unnatural, but an anti-natural, advantage to those who build bad ships, those who man their ships with incompetent hands, those who load their ships badly-keeping a hand, as it were, over the eyes of the master of the ship that he may not see, or over his mouth that he may not speak. How can progress in shipbuilding and in all that goes to make up the course of trade by the great natural highway, the sea, be as rapid and as steady as it should be, when so many are struggling hard against progress? Let those who would pooh-pooh such an idea remember that mankind is a growth, and, like any other growth, when it ceases to grow it begins to decay. It may be that our honest shipbuilders and shipowners and our competent seamen are too large and sound a body to be corrupted by this virus-spot. But there is one condition alone upon which that may be; and that is, that the good shall cast out the evil. Let the evil be tolerated and it will grow, and the more it grows the greater the effort needed to get rid of it. Real trade must overcome or be overcome by this gambling, in which insurance keeps the table, and ships and their crews are used but as counters in the game. 


\section{CHAPTER VII}

\section{FIRE INSURANCE}

Its Nature and the Nature of the Abuses to which it is Liable-Some Account of its History-The Position of the Agent.

I considering fire insurance and the abuses to which it has given rise, we find ourselves dealing with a subject offering marked contrasts to marine insurance. The change is decidedly for the better. While we must consider crimes of a desperate nature, as well as widespread demoralisation resulting from a system partly vicious, we need take into account only loss of property, and not, to any marked, extent, loss of life. Moreover, we leave a highly technical subject and one of which it is almost impossible to speak without involving oneself in danger of misunderstanding, and turn to one far more understandable and far more generally understood; a subject, also, in which reform should be far easier of accomplishment than in one involving the well-nigh clueless mysteries and warring interests and opinions that have already been noted in marine insurance.

That the evils of fire insurance are, at least in a general way, well understood, is proven by the fact that the very jokewriters have taken up the idea. How often, oh, how often, are the changes rung on that ancient humouric tour de force about a fire being caused by friction-the friction between a two-thousand-dollar stock of goods and a five-thousand-dollar policy of insurance! Everybody knows that many fires are due to the desire of the owner of an insured property to realise from the 
insurance company the amount of an insurance greater than the value of the property itself.

The question will naturally be asked: If this is so simple a matter, and if the public know so much about it, how do we explain the continuance of the evil consistently with the theory of the curative properties of publicity in such affairs? The answer is that public opinion does have an effect, the evil not being nearly so great as it would be were not attention so generally directed toward it; and, secondly, the evil exists even in its present proportions because the publicity is not sufficiently great,-that is, the knowledge of the facts on the part of the public and the public's understanding of the meaning of these facts is general and not specific, and, therefore, less effective than it would otherwise be. What is needed is not only that the people should know the general bearing of the facts, but that they should understand the measures of reform which those facts suggest.

No great branch of insurance seems to have attracted so little the attention of historians as this. The materials with which the historian of fire insurance would be obliged to work are scant and scattered, insomuch that one man, no matter how long-lived, able, and industrious he might be, could not gather enough of them to make a work at all complete. If we are ever to have a history of fire insurance, it must be as the result of the labours of many, each adding to the stock such facts as he can gather. According to many who have written on this subject, fire insurance arose in answer to the demand created by the Great Fire of London in 1666. But this statement is probably due to the complaisant desire of the historian to please the public with so-called facts having an air of precision and finality, rather than to any real knowledge on his part.

It is true that, so far as England is concerned, the Great Fire revived in London a demand which, for special reasons, 
had lain dormant for some time, and so gave rise to commercial institutions intended to save people from the losses caused by fire, which institutions are historically connected with the fire-insurance companies we have to-day. But the form of fire insurance that appeared in London about the end of the seventeenth century was considerably different from that of the present time. It is unreasonable to trace the stream back to one particular enlargement of it and count that as the source. That would be like following the St. Lawrence River back to Lake St. Peter and assuming that to be its headwaters, instead of following it, as we do, back over the Rapids, through the Thousand Islands and the Great Lakes to the "Big Sea Water," Lake Superior.

As there never was a time, at any rate in the history of northern nations, when the people did not suffer loss through uncontrolled fire, and as there never was a time when men did not unite for their common protection against adverse forces, whether of the elements or of other tribes of men, so there never was a time when fire insurance in some form did not exist. I refer now to the true insurance which provides a fund to indemnify for loss. The old guilds, whose existence in some form was part of the life of the people as far back as we can go in their history, had this as one of their objects. One can imagine that, in some societies, it was not a very prominent object. For instance, Adam Smith tells us that in some parts of Scotland, even in his own time, the building of what was called a house was the work of one man for one day. Under such circumstances, the loss of a house by fire would not be considered a matter worth bothering the neighbours about. In the wooded part of America, the settlers can easily put up as good a house for each family as that family cares to have. But the lifting of the heavy logs is a job beyond the strength of any man. In the case of the burning down of a cabin, the ready help of the neighbours, through the 
instrumentality of that fine social device, the "bee," performed - still performs in many places-all the work that is done in the more complex social life of the cleared country and the cities by the fire-insurance company.

But, historically, there was at least one intervening stage between the ready application of the traditional and unquestioning good-will of the neighbours and the organisation of fire insurance as a separate business. During that stage, the trade guild or some similar co-operative organisation performed this function. As we take this step in advance, however, we see how the opportunity for abuse arises. The settler in the bush whose cabin is burned down can have the dwelling restored, perhaps in somewhat improved form. But he cannot pretend a loss that has not occurred, for every item of his property, from the cattle in the lean-to to his "store clothes" hanging on a peg in the corner of the "best room," is known to his neighbours. A fraudulent fire to win sympathy and increase his possessions is such a clear impossibility that it would never even occur to the most imaginative mind. But the guild of the middle ages or of ancient times was subject to impositions of various kinds, which naturally increased as neighbour-knowledge grew less, property accumulated and became diversified, and the funds of the societies grew larger. One author whom I find quoted on this subject attributes the very name "guild" to a Saxon word meaning "to pay," the name having arisen because all members were required to pay into the funds of the society. The Encyclopadia Britannica countenances this derivation of the word. Without discussing this point, it is not hard to understand that a body of traders, many of them wealthy, would, by contribution and inheritance, acquire funds smaller or larger according to circumstances. Such funds, of course, would be a constant temptation to those whose needs were stronger than their consciences. And, if fires were among the keys to unlock the strong-boxes of the 
guilds, we may be sure there were fires so planned as to win a maximum of indemnity by a minimum of loss. The precautions taken by the Scandinavian guilds to prevent imposition, as shown by the reference to $\mathrm{Du}$ Chaillu in a previous chapter, prove that imposition was early attempted.

Not undertaking the unending task of tracing the history of guilds in this respect, it is worth while, seeing that fire insurance as we have it to-day developed first in England, to consider the effects, known or probable, of certain events. Mr. Toulmin Smith, in a work published in 1863 , said that guilds existed before any known English kings, and that, in the laws under King Alfred and others, reference is made to still older laws in which "it is taken to be a matter of course that everyone belonged to some guild." Modern students are beginning to see in these associations one of the main currents of history, and to understand that their working is far more worthy of study than the movements of many kings, warriors, or courtiers, who are often only the bubbles made and borne along by the stream. The Reformation found the guilds in England and other places wealthy, conservative, and not overcareful of the rights and interests of those outside their own membership. Henry VIII., of England, having found the plunder of the church insufficient to meet the wants of his court and his army of spies, made a descent upon the guilds also. Only those survived that were able to make a show of stout resistance, usually combined with a "loan" to his Majesty. This policy was repeated by Edward VI. and Elizabeth. In fact, the guilds were destroyed and nothing was substituted for them.

The losses by fire were not stopped, however, and many suffered most severely. One expedient that was tried before the invention of fire insurance as a separate trade was what is known as the "fire brief." I do not say that this device was not in use long before the guilds were destroyed; in fact, it seems most probable that it was. But the first mention of it 
that I find in Walford, the most painstaking and voluminous writer on these subjects, is in 1653, during the Protectorate of Oliver Cromwell. The idea of the fire brief was that sufferers by fire should be commended by the head of the nation to the benevolence of charitably disposed people. The occasion of the first fire brief mentioned was the burning of 224 houses in Marlborough. Copies of the order of the Council, in which the Protector - who personally subscribed $£ 2000$-requested donations, were distributed through the sheriffs and chief constables to the churchwardens of each parish. Collections were made and the money was sent through proper channels to treasurers in London, whose business it was to distribute relief to the sufferers.

A mere glance at such a system is enough to reveal the opportunities it offered for imposition and fraud. Its speedy death was certain from the beginning. A case of abuse was brought before the House of Commons in r 7or. According to one of the witnesses, one Pemberton made an offer to certain parties to provide the money to secure a King's brief, if the others would agree not to prosecute him for losses they had suffered through a fire that had arisen in his place, and would sign the necessary petition. "He told me that he had skill in the business, and that he knew some men in the country that had got good estates by gathering charity, and that it would be a constant spring to us," said one witness. It is unnecessary to follow this confidence game;-it is easy to see that it would soon be resorted to by sharpers on the lookout for a chance to take the money of the King's lieges. The history of some of those who had "got good estates" out of this game would be interesting reading, if the facts could be collected; but this is not the place for such an investigation.

Like all other inventions fire insurance took its rise in the necessities of the time; and, as in the case of so many other inventions, the idea was hit upon by two or more people 
about the same time, people who arrived at it, as it were, from different directions, and who viewed it from opposite sides. At the risk of losing time, I would remind the reader that the guilds were generally part of the municipal life; in many cases they were, in fact, the municipal organisation. Therefore, that which they afforded the people was not merely indemnity in case of fire but protection from fire. It was the guild, in some form or other, that organised what we should call the fire brigade, and also the police force, part of whose business it was to protect against thieves property removed so as to be out of danger in case of fire. When the protecting power of the guild was removed, when the king and the common citizen had something to say in municipal management, and the brethren of the worshipful companies of fishmongers and others lost the despotic control they had at one time enjoyed, it became necessary for the King, or the Commons, or somebody else, to provide what the guild had provided - protection against fire and indemnity in case of fire.

In our day we have pretty well come to the conclusion that fire protection is the business of the community; and so we see everywhere the town controlling building, as to materials and methods of construction, and also controlling and directing the fire brigade, the salvage corps, and the protective police. When a fire occurs, the servants of the town assume complete control, even, if necessary, to the extent of excluding from the precincts of the fire those persons whose property is undergoing destruction-on the principle, supposably, that the good of all the people is the supreme law. On the other hand, the indemnifying of those who have lost is left to the insurance companies-in other words, it is left, not to the charity of the community, but to the thrift and forehandedness of those who are exposed to danger.

It is true that fire insurance is not yet altogether out of its swaddling clothes, for we find even some of the greatest 
companies providing salvage corps and fire extinguishers for the benefit of the community. This is, in part, an outcome of the mutual principle, as fire-insurance men call it, which, while here recognised, cannot be here considered without danger of confusion, but which is left to be dealt with later.

Though the distinction between protection against fire-a community duty - and indemnity for loss by fire-an individual choice-seems clear enough to us, it is hardly to be wondered at that there was confusion upon the point in the minds of those who had but recently emerged from the system under which both these functions were performed more or less directly by the municipality. In London, a fire insurance and protection society was proposed in a petition to King Charles I. in 1638 . But, though his Majesty gave his assent to the proposal, we find no further record of it. No doubt, the proposer, like the King and the rest of the people, had other things to think about. Certain differences of opinion between the King and some of his subjects were reaching an acute stage about this time; and four years later, Charles found himself engaged, as he supposed, in putting down a rebellion, but, in fact, preparing his own way to the headsman's block. Even after the King was beheaded, the people had many and vexed questions of the next world to settle, including some respecting fire which, as they said, could not be quenched, and for which, whatever protection there might be, there was certainly no indemnity. But the affairs of this world came more prominently forward for consideration after the great Lord Protector died and the Stuart dynasty resumed the throne in the person of Charles II. It was in 1660 that this monarch commended to the Common Council of London a fire-insurance scheme which had been proposed. The idea was not acted upon, however, because it was in the form of a private enterprise, and the Common Council thought the City should have the responsibility in such matters, and also the profits, if any. 
The Great Plague and the Great Fire wiped out the London of those times, and that which was built up afterwards was new, not merely in the new bricks and mortar that replaced old wood, but in the spirit which dominated the metropolis. When the people recovered their energies, many new schemes were proposed, among them two that are especially worthy of mention here-a fire-insurance and protection company, and a system of fire insurance and fire protection to be carried out by the City. The company was ultimately established and the municipal scheme almost came to perfection also, but not quite. The controversy between the representatives of these two schemes was lively. Those who care to read it can find a wonderfully complete record in Walford's Insurance Cyclopedia, under the heading, "Fire Insurance, History of." The result of the discussion, as has just been suggested, was that the stock company won and the municipal scheme failed to carry.

The effect of this, as will be seen, was to hand over not merely the business of insurance, but the duty of protecting the citizens against fire, to a private company. Of course, the idea was an absurd and unworkable one. Carried out on a business basis, it would have meant that only those who paid premiums to the company or companies would have their property saved from destruction. The Englishman's proverbial capacity for compromise enabled London, in some way or other, to stagger along under this system for almost two hundred years, the fire-fighting work of the insurance companies being finally taken over by the authorities in 1866 . The status of the companies as to contributions to the funds for this purpose is not yet quite defined. For very many years, the duty of the city to protect the property of citizens against fire has been completely recognised in other places, especially in the United States. The recognition of this principle had the effect of establishing the counter-principle, that the business of indemnifying for loss by fire should be left to private 
arrangement. But, as has just been seen, the distinction between the two ideas was not made when fire insurance upon modern lines was inaugurated in London.

The history of fire insurance since that first company was established is a record of development. The system is now universal in the English-speaking world and among many other peoples as well. Fire insurance as a separate business, as will be seen from the explanation already given, is an unnecessary and unworkable thing except in a rather advanced state of society. The more primitive methods of doing the work which is now done by insurance companies are still in use in communities of less complex social organisation even in English-speaking countries.

This naturally leads to the mention of what may be considered a confluent branch of the history of fire insurance. The L,ondon of the time of Charles II., with its varied interests but poorly cared for under a municipal organisation which had been shaken by revolution, pestilence, and fire, might naturally look to private parties to provide this form of indemnity, so necessary to the life of trade. But in smaller communities, with more stable conditions and less danger of loss by fire, the communal system in some form might well be allowed to continue. And it does continue to this day. For instance, we find it in voluntary operation in the mutual fire-insurance companies which operate so largely in the agricultural portions of America, as well as in some of the manufacturing districts. It is found desirable to combine, to some extent, protection with indemnity. Not that the mutual company seeks to control the fire-fighting organisation or to direct the work of extinguishing fires; but it seeks to prevent fires by prescribing certain rules as to building, equipment, appliances for fighting incipient fires, use of heating apparatus, and so on. This involves a system of inspection which is not necessarily a part of fire insurance, though the present tendency on the part of stock 
companies is to resort to it also. The mutual companies do a useful work, but their field is limited-or, rather, the field of each one is limited. A number of people who have intimate knowledge of one another's character and property, like the farmers in one locality or the manufacturers of one class of goods, may advantageously combine for the purpose of mutual insurance and common protection against fire. Mr. Edward Atkinson, who has made himself prominent in many ways, will probably live in history as the man who made a success of what are known as the New England Mill Mutuals-companies for the inspection and insurance of textile factories in New England. Mr. Atkinson himself is on record as stating that the principle is not applicable to the insurance business of cities and crowded centres.

No statistics would be possible to show the extent of the fireinsurance business as now practised, for those figures would need to be as large as those of all trade. There is practically no combustible property that is not insured against fire; every car of grain, every scow-load of lumber, every bale of cotton, every package of manufactured goods, from the time it assumes merchantable shape until it is entirely consumed, is thus conditionally the property of insurers. Without such a system, as has already been said, modern commerce would be impossible. The fire-insurance policy, or the assignment of certain interest in it, is attached to the mortgage given by the farmer for money to build his new barn; the fire-insurance policy is as necessary to the banker as is the warehouse or shipping receipt on the strength of which he advances funds for that magic of commerce, "moving the crop" ; fire insurance is as important to the manufacturer as is the foundation under his factory;fire insurance is, in fact, the very backbone of that part of our social life which has to do with making, moving, and keeping material things.

That a system so gigantic, so wide-spread, and so constantly 
in use should have its abuses is not to be wondered at. That it can ever be made perfect is, of course, unthinkable. Still, its very immensity and its intimate relation with our every-day comfort make it imperative that it should be made as pure and strong, as much serviceable and as little injurious, as may be.

There are reasons why fire insurance should be less abused than some other great branches of the business. These reasons may all be summed up in one-the comparative simplicity of the contract. The casualty insured against is one, differing in this respect from marine insurance, which insures against the innumerable dangers of the sea. The property insured is, in the main, stable, accessible, and inspectable by the insurer and his agents. These being the elements of the transaction, there is no reason why the contract should not be one which any common man can understand, and no reason why any common man should not treat it as a matter quite within the range of his understanding.

And the causes of abuse, varied as they may appear, are also traceable to one source, - and that the main weakness of all insurance, - the fact that the property is in charge (directly or through agents) of one party, the owner, while another party, the insurer, is responsible in case of loss. As in the case of ships and their cargoes, so here; - the carelessness and incompetence of employees is one of the dangers to which owners of property are liable, and it is necessary, if the insurance system is to be complete, that the insurer should assume that risk. Subject to limitations stated in the conditions of the contract, the insurer does assume it. If an employee changes the character of the property, -if, for instance, he stores gunpowder where nothing but hardware is supposed to be stored,- he, by that act, cancels the policy. But, if he is merely careless in the handling of heating and lighting appliances, he is so at the risk of the insurer, ordinarily speaking. Even the owner's 
carelessness is insured against. After a fire, the owner may frankly confess that some inconsiderate act of his own caused the fire, without any fear that payment will be refused. This being the case, we would naturally expect insurance companies to take the greatest pains either to exclude careless or criminal people, or to grade insurances according to the character of those in charge of the property. If the underwriter bases his rates only upon the nature of the property itself and leaves out of account the character and circumstances of those in charge of it, he undertakes to work out a correct result while ignoring important factors in the calculation. I have seen it urged in an insurance periodical-one of those true words that are sometimes spoken in jesting hyperbole-that the nature of the building makes no difference at all, the only question to be considered being the character of the occupants. And, to prove this, the well-known fact is quoted that hundreds of wooden buildings stand for half a century or more, and, during the same time, adjacent blocks of brick or stone or iron are burned, rebuilt, reburned, re-rebuilt, and burned again. In this connection, the words of Mr. Atkinson, who has already been referred to, may be quoted:

The only persons who can prevent loss by fire are the owners and occupants of the insured premises. Upon them rests the responsibility for heavy loss, when any occurs, in nearly every fire. . . . So long as this fundamental principle is neglected by owners and occupants of real estate, all charges against cities, underwriters, and fire departments are futile and foolish. It is as hopeless to try to help a capitalist to save his property from loss by fire who is incapable of fulfilling his own duties to the property and to the public as it is hopeless to try to lift an incapable or intemperate workman to the level of a skilled mechanic.

This element of personal character as a factor in estimating the danger of loss is recognised in the business, at least to the extent of giving it a name. It is called the "moral hazard." It is easy to understand the effect of this moral hazard as an 
element of fire insurance. A supposititious case has already been cited of a person changing a risk by storing gunpowder in a building nominally used for a less hazardous purpose. But, even though there is no change whatever in the physical nature of the risk, there may be changes with regard to the owner which will do more to endanger the property than would the starting of a powder factory on the premises.

Suppose, for instance, that, in a community where the spirit of revenge is known to direct the actions of some men, the owner incurs the enmity of parties who are handy with matches and kerosene, is it not clear that the danger of loss is multiplied many times? As I write, a case is reported from a Canadian city of a contractor living under the ban of a striking tradesunion, and of no less than four fires started in a building he was putting up with the assistance of imported labour, the firebug being a criminal lunatic who said he was actuated by sympathy with the strikers. This is an extreme case, but it illustrates the point. The day before the strike that contractor, if a good citizen, might well have been granted all the insurance he wanted at ordinary rates; a week later no manager who was fit to be at large would issue a policy to him at less than one hundred per cent. Or, suppose that a man who has been doing a successful business is struck by a financial squall and is threatened with bankruptcy,-is it not clear that he is less fit to be in charge of insured property than he was before? To leave this man in the same class insurance-wise as he was in before, to grant him the same amount of insurance at the same rates, would be sheer madness.

How this element of the moral hazard is treated by the insurance companies, so far as the mere success or otherwise of the companies is concerned, is no affair of ours. But fire insurance, like any other form of insurance, is a factor in our social life, and if it is so used as to do us injury, we of the public have a right to protest and demand reform. That the manner 
in which the moral hazard has been treated by those engaged in fire insurance has caused great and unnecessary injury to society is the burden of what I have to say upon this branch of the business; and the greater part of the facts given in this and the next two succeeding chapters is designed to illustrate this point. There are signs of improvement, decided improvement; and it may be that by the time this comes under the reader's eye a revolution will have taken place. On the other hand, the advance may be merely temporary, and the business may revert to as bad a position as any it ever occupied. To avoid dealing with what may prove merely a passing phase, I shall take my facts mainly from the records of half a generation ago. The question what insurance is at the moment does not concern us. What we really need to know is what insurance probably will be or may be, and the best way to form an intelligent opinion on that subject is to learn what insurance has been.

If fire-insurance operators were merely to disregard the moral hazard, that would be bad enough, for it would mean that all property that was equal in regard to the physical hazard would be treated alike, and the owners, whether wealthy or insolvent, careful or reckless, upright or criminal, would be subject to the same conditions and would pay the same rates. There are reasons why fire insurance should tend in this direction. Notwithstanding the vastness of some modern business concerns and the fine division of labour that characterises modern industry, our business dealings are still carried on man to man; and, while it is good business policy to suspect every man until he is proven honest, it is not practicable in business to give a man to understand that you regard him as a rogue and still keep his custom. If two neighbours in similar houses, and having property of equal value involving equal danger of fire, find that they are paying to the same company markedly different rates of insurance, or are granted insurance in markedly different 
proportion of value, the one who is at a disadvantage will naturally demand an explanation. In doing so, he deals face to face with the company's agent, who is also a neighbour. That agent can hardly explain that the higher rate and lower amount of insurance are due to the fact that the insured is insolvent, or that he is careless, or is suspected of contemplating arson. Where possible, it is much easier and pleasanter to raise the rates all round and make a profit out of the average. We have already seen that this was the course pursued by the British marine insurers. One who glances over the current literature of fire insurance for the last fifty years or more will see that this is the course that has been practically attempted, if not theoretically set forth, by those in the business. At least two generations of men have been engaged in making compacts and agreements among companies to increase rates and maintain them at a point at which the moral hazard could safely be left in a secondary place in the calculation. In this respect the business has been carried on in a cynically and disgracefully unscientific fashion. Not merely has this been done by the constant agitation carried on by many of those engaged in the business for compacts, associations, agreements, and understandings to keep up rates, but by the persistence of the companies in a system of remunerating their agents which identifies the interest of the agent with that of the careless man and the criminal, a system which has helped to make arson an industry, as similar folly in marine insurance made barratry a trade. The effect of this upon the public will appear from the facts given in subsequent pages, and we need not dwell upon it here. We may proceed at once to an explanation of this injurious method of remunerating agents.

Allowing for enough exceptions to prove the rule, it may be taken as the law of fire insurance-and by this it is not intended to either deny or assert that the same may be said of other branches-that the agents of the companies are paid by a 
percentage upon the amount of the premiums they collect"commission," as it is technically called. So far as I know, nobody defends this system as a good one; the excuse for it is that there is no other plan that is not open to still graver objections. However the argument, may go, from the point of view of those engaged in the business, I think it safe to say that, so far as the public is concerned, the commission system is the worst that could possibly be devised. It seems plain to me that to this system is due a great share of the evils to which fire insurance has given rise.

A scoundrel who wishes to have a profitable fire would naturally find difficulty in inducing the company to accept his application at all. But an applicant for insurance deals not with the company, but with a middleman-perhaps a regularly appointed agent or perhaps a broker-and this agent or broker has a direct interest not merely in securing the business but in making the amount of the policy as large as possible. Of course, every insurance agent will tell you that he never was influenced by such a consideration, that he has declined hundreds of risks because he knew they meant certain loss to his company, and because his reputation is more to him than money. The same man, however, will tell you that the most suspicious customer can have insurance for any amount that can be shown to be within even hailing distance of reason. Therefore, if, in finding fault with the system, I should fall under the imputation of questioning the adamantine virtue of any man, I ask to be understood as saying that the imputation has nothing to justify it. He whom I suspect of being sometimes influenced against the interest of his company is the other man. Let us at least start fair.

Just to show what this other man will do, let me cite one or two authorities. But first, it may be necessary to state clearly that it has been the custom to pay commissions not only to regular agents of the companies, but to agents of the agents, 
or even to outside parties who control business and who are known as brokers-which they are in fact-or, in some places, technically as "scalpers." Here is a protest, for instance, from The Insurance Monitor, then under the editorship of the late Mr. C. C. Hine, whose prominence as an authority is attested by the fact that he was selected to write the article on fire insurance for the American edition of the Encyclopoedia Britannica. A man had had seven fires within a few years, being well insured each time. Yet, says the Monitor, "this man will-judging by the past-have no difficulty in again procuring all the insurance he may want." And this in the teeth of the fact that the Monitor itself issued a daily bulletin of fires, so that the man's record was in possession of the companies, or, at least, was open to their inspection. Then, the late Mr. D. A. Heald, a veteran in the business, president of a great insurance company, the strongest man in the National Association of Fire Underwriters, and president of that body for a greater number of years than any other man, is quoted as saying in 1886 :

The commissions paid by New York companies last year were 18.92 per cent. against 6.87 in 1860 . Whence this fearful increase? The answer is, excessive commissions to agents and enormous brokerages to middlemen. The higher the brokerage the more brokers; the more brokers the greater competition; the greater the competition the lower the rates ; the less the rate the higher must be the brokerage - so in an everrecurring round this has gone on until the commissions paid by the New York companies have run up nearly 300 per cent. in twenty years. . . Comment is unnecessary; justification is impossible.

The effect of this system is to make the agent-I beg pardon, the other agent-the representative of the insured rather than of the company. Nothing could possibly be more unreasonable or unbusinesslike on the face of it. The company seeks to make its profit out of the difference between receipts and losses; the agent who has charge of the business at the point of origin, 
and who must, in the nature of things, know more about the business than any other officer of the company, seeks to make his profit by increase of receipts, having only a remote interest in the question of losses. The company is working out a sum in simple proportion; the agent, upon whom the company depends, is working out a sum in simple addition. The company is one, the applicants for insurance are many; and the interests of these two sides of the transaction are at least as far apart and as much opposed as those of buyer and seller. Yet the company deals through agents whom it pays, not in proportion as they maintain the company's interest, but in proportion as they maintain the interest of the other side. To say that a certain proportion of misrepresentation unfavourable to the company's interest does not appear in the papers sent in by the agent, is to say that the company has a charm for making men work to cut down their own wages, and that continually. To say that all these misrepresentations are seen and checked, and that none of the business on the company's books is any the worse for them, is to say that the company possesses the touchstone of truth. The idea would be absurd enough under any circumstances, but it is particularly absurd considering the conditions under which fire insurance is conducted as a matter of every-day business.

The agent, as everybody knows, does not wait in his office parlour to give audience to suppliants who seek the privilege of being insured against fire. The competition in the business is such that he "hustles," to use a word common among the fraternity. And this is the process in fact:-A new-comer in town opens a store. The fire insurance agent-five or six of him, perhaps-seeks the business. The storekeeper says his stock is worth $\$ 6000$ and he wants it insured for $\$ 4000$. This means, let us say, a premium which, on the basis of his commission, will yield the agent $\$ 6$. The agent may have an opinion that the stock is not worth more than $\$ 4000$, and that 
it is being insured to its full value, which is contrary to common sense and to insurance practice. Will the agent propose to insure it for $\$ 3000$, cutting his own commission to $\$ 4.50$, while running the chance of losing the business altogether and of offending a new customer-and this with the knowledge that if he does not take the business another agent will ? Will he not be more likely to argue the case in his own favour? "I am not an expert in this storekeeper's line," he may say. "He knows the facts and I do not. He must sign the application, and he looks like an honest man. I can watch him, and, if I see anything suspicious, I can have the policy cancelled. Besides, there is a clause in our policy that only three-fourths of the actual loss is to be paid, and that will save the company in any case." As a matter of fact, the agent does reason thus, until, by repetition, it becomes a habit, and the habit of himself and others makes a custom in the business. This constant pressure of self-interest must have and does have an important effect upon the whole volume of fire insurance. This will abundantly appear when we come to deal with the question more in detail. It appears also in a vast body of facts of such an involved and technical character that it is not advisable, in a work like this, to do more than merely refer to them.

The outcome of these facts is to be seen in what are called the "valued policy laws" which have been passed by the legislatures of a number of the States of the American Union. These laws are passed to meet a condition brought about by the method of carrying on the fire insurance business which is now under criticism. Finding many claims made upon them for more than the actual value of the property destroyed, the companies adapted to their business a policy condition long known and used in connection with marine insurance. Under this condition, in case of total destruction of the property insured, the person insured would be bound to set forth the value, which would be subject to contestation by the company; 
and, the value being settled, the company would pay only a proportion-usually three-fourths-of the loss. The position, as a matter of business, would then be this:-The insured is demanding the fulfilment of a contract according to his understanding of it, that contract having been voluntary as between himself and the agent of the company and with no knowledge on his part and no intimation on the part of the agent that there was any limitation of the insurance save the amount of the policy. The insured has paid, it may be for years, for the whole amount of the insurance, dealing with the company's agent in the full belief that, in case of loss, he would be indemnified on the basis of the amount on which he had been paying. Now that the policy has matured by the happening of the contingency insured against, the insured finds that he is entitled to a smaller sum than that he had calculated upon. The situation is not improved from a business point of view by the fact that, whereas the insured has hitherto dealt with his neighbour, the agent, who was more highly remunerated by reason of the fact that the insurance was large, and whose interest it was to have it large, he now finds himself dealing with an inspector or adjuster, who takes only such account as he pleases of the representations verbally or tacitly made by the agent, and holds himself free to resort to a not very understandable condition printed in fine type on the back of the policy.

Of course, it is the interest of the company, in a general way, to conciliate its customers, and it is more than likely that the inspector or adjuster will make concessions far beyond the actual legal terms of the policy. At the same time, the insured finds that whereas the representative of the company who took the risk had an interest in accordance with his own, the representative of the same company who deals with the matured policy has an interest which, at the very most that can be said of it, is not that of the agent and the insured himself. So completely is this recognised, that the inspector or 
adjuster who knows his business will hold, not merely the insured, but also the agent at arm's length, as though their interest were a common interest and that opposed to the interest of the company. That this statement may not be regarded as unworthy of acceptation, let me put back of it just one brief quotation. At the meeting of the Fire Underwriters's Association of the Northwest, in September, I886, Mr. J. J. Berne, an insurance adjuster, read a paper setting forth the best methods in his line of work, and, in the course of it he said that, above all, the adjuster "should be guarded with the agent. His idea of insurance is commission, and he is usually on the side of the assured."

Experience the reverse of pleasant taught many business men in the United States that the amount of the insurance for which they had paid was not necessarily the amount upon which their losses were adjusted. This experience led to an outcry for the redress of what was, not unnaturally, regarded as a grievance, and this, in turn, led to the passing in a number of States of the valued policy law. The effect of this law is to apply generally to fire insurance contracts the rule which, as we have seen, was often applied in marine insurance, and under which, in case of loss, the claim was settled on the basis of the amount on the face of the policy-that is, in case of a total loss, for instance, the amount of the insurance should be paid without abatement. This is written not to either uphold or condemn such a law, not to either uphold or condemn the action of any company or companies in enforcing the average clause under the circumstances. That is a subject which, for its proper treatment, would call for a special study and a separate book. The purpose in mentioning it here is to show that this evil of over-insurance is recognised as a practical condition by insurance companies, and that they have tried to meet and overcome it. But that evil is necessarily and constantly increased by the conditions the companies impose upon their 
agents, and thus insurance, in this, as in so many other cases, is made a direct incentive to the increase of carelessness and crime.

The question naturally arises: If the case is so simple and obvious, why do not the companies change the system and so remunerate their agents as to make the agent's interest conform to that of the companies he represents? And, if they do not make such a change, is not that proof positive, or, at the very least, presumptive evidence, that the case is not as stated, though it may appear so?

I confess at once that the question is a staggering one, and that the explanation I have to offer still leaves something to be explained. In the first place, I cannot doubt the facts, for I find fire insurance literature filled with references to them; and the facts as here given seem to be accepted as a postulate in working out the problems of the business. For instance, the joke-a feeble one as I have given it, but better where more fully understood-about the other agent, is not mine; it is of high antiquity in the business, and I could quote fifty variants of it. I could quote also insurance men who see in this commission system the fountain head of all the evils that afflict the business. Space will not permit the piling up of a mass of evidence on this subject. Some quotations will be made incidentally in succeeding chapters where the practical ills to which the abuse of fire insurance has led are dealt with, and these must suffice. In view of the mass of evidence on this subject, I cannot believe that the facts can be other than as they are here given.

Why, then, do not the companies make a change? For several reasons. In the first place, you cannot change from somewhere to nowhere. Some system must be substituted if the present is to be done away with. No obviously complete and perfect system has been proposed, and each company hesitates to risk its life or even a dividend or two upon an 
experiment. The difficulty of change is enormous and its risks incalculable. In the second place, change is not necessary in the interest of the companies. As has so often been said already-and as must often be said again, I fear-the loss is not paid by the insurance companies but by the public. In this, as in other cases, a possible remedy, and one which, if it succeeds, is quite satisfactory to the companies, whatever may be its effect upon the public, is to raise the rates. In this way the companies can cover not only the loss that occurs through unavoidable accident or through the carelessness and stupidity of men, but also the loss that arises through their own-the companies' own-error, their own folly, even their own criminal conspiracy with the worst element of society.

I admit that this explanation may leave much unexplained on one side, yet seem to explain too much on the other. The reason may be good as concerns the companies as a whole, but why is it that some company does not come out, and, by altering the system, secure a class of business which, at present rates, would pay magnificently? That is, why does not some company seek all the business in which the moral hazard is good, and leave to the others all the business in which the moral hazard is bad?

In the end, I shall be obliged to confess, as I have done already, that there is a residuum in this question which will not yield to any solvent known to me. But there is a point which may explain it in part. Insurance, like any other business, can be carried on successfully only where enough business is done to pay fixed charges and more. The organisation of a company, including selection of agents, is an exceedingly expensive matter. Moreover, it is a business which must be spread. A factory can sell its whole output to one concern and still succeed. But a fire insurance company cannot risk its whole capital in a few big policies. To do that would be to ignore the principle of average, the great law of probabilities, 
which is the very foundation of the whole business. Looked at from the side of the insured, this means that every business firm that has any considerable amount of insurance to pay for must have policies from many different companies. In practice, it is found that it is better to have the policies in such cases in exactly concurrent terms. Even a specially low rate from one company is not an unmixed advantage, and may, in fact, be worth less than nothing, if it suggests doubts as to the solvency of the company that charges it, or makes necessary any special calculations on the part of the insured or special record in his books. Security is the first thing desired, but uniformity is almost equally important. This desire on the part of the insured for uniformity tends to compel uniformity on the part of the companies. The company that starts on a new line is apt to find itself shut out from this large mercantile and manufacturing line of risks which are, so to say, the staple of the business and which involve the least cost in agency and management expenses. To ignore or neglect this line would be, at the very least, probably, to postpone the dividend-paying period for a new company; and shareholders are proverbially the most impatient and unreasonable people in the world.

Germane to this point also is the fact that the agents have been trained in the commission system, and any change would probably involve the selection and training of a new body of men on new iines to suit the new system, whatever it might be. In the old days some Hercules was looked for to perform such labours. But in our time the prompt and simple method of running a couple of rivers through an Augean stable would be regarded with disfavour by riparian owners and others, and so we have invented evolution as our agent of reform. The cleaning of our Augean stables is not quite so speedily done, but we save the fertiliser and avoid some lawsuits.

These are some reasons which account, in part, for a condition of things which, it seems to me, is not really advantageous 
to the companies. That which is unexplained I find classed in my own mind with such mysteries as the fact that a man who knows he ought not to drink, and who intends not to drink, nevertheless will drink and become drunken, or the fact that a free and intelligent people will sometimes allow themselves to be exploited for the benefit of men whom they have no reason to love and who cannot present any reasonable claim for public sympathy and aid.

But, whether the commission system is or is not to blame, the fact is, as will be abundantly proven in the next two chapters, that, in contrast to all the good it does, fire insurance, as practised, has the effect of promoting carelessness and even crime; it is a cause of great unnecessary loss and of widespread demoralisation. In the quotation from his writings already made, Mr. Edward Atkinson finds the property-owner to be the cause of loss, and says that until there is reform in that quarter, "charges against cities, underwriters, and fire departments are futile and foolish." But, so long as fire insurance offers a premium to the careless or criminal owner, reform on the part of owners will be retarded. It is not necessary to find fault with individual underwriters, much less is it necessary to condemn the whole system. But abuses must be observed and removed, and whatever changes may be necessary to that end must be made. 


\section{CHAPTER VIII}

\section{FIRE INSURANCE-Continued}

Some Instances of the Abuses that have Existed - Statistics and the Statistical Argument - Actual Fire Loss and how it is Affected by Insurance-Firebugs and their Methods - The Effects of Fire Insurance Abuses in Great Britain.

THE effect of what has already been said on the subject of fire insurance is that the amount at risk by fire insurance companies, if those companies are not properly administered, stands as a great bribery fund to reward the careless and the criminal for losing their own property and endangering the property and the lives of others. For that is a feature of this form of insurance that must not be forgotten. A man may scuttle a ship, and, if he does his work at all efficiently, that ship will sink and never more give anybody trouble. But a man sets fire to a little shanty for the purpose of realising a few dollars from the fire insurance company, and, before the last of that act is seen a whole town may be in ruins. A man may try to sell out to an insurance company, through a fire, the contents of a small room, and the lives of scores of persons be thereby put in jeopardy. I find the statement frequently made, in the discussion of this subject in the insurance journals, that the effect of insurance as a fire-raiser must be small because the amount of insurance money involved in incendiary fires is little as compared with the total fire loss. But this argument is based upon the childlike-not to say childish-assumption that the incendiary remains at hand until the property on which he wishes to realise has been consumed and then conscientiously, 
as becomes a kindly law-breaker, puts out the fire. Even if this were part of his original plan, there might be cases in which he would find it not easy to carry it into effect.

This argument is like one attributed to Dr. Fowler, the learned and painstaking author of The History of Insurance in Philadelphia, to the effect that fire insurance does not cause incendiarism, the proof being that there is less incendiarism in Philadelphia now than there was in the old days before insurance was so generally used. This is our old friend the statistical argument, again,- - the argument of average. It is told of a learned statistician of Philadelphia that he proved, to his own surprise and that of his friends, that three hundred per cent. of the Turks in that City of Brotherly Love were criminals. The question naturally arose where that odd two hundred per cent. came from. Investigation of the original figures upon which the tables were based revealed the fact that there was but one Turk in Philadelphia, and he had been in jail three times.

The statistician is all right, but he must be taken on his own ground. Dr. Fowler, or anybody using his name to give weight to an argument, would hardly venture to say that there was no such case as that of a firebug burning down a property for the insurance. The mere fact that such cases are few, if it be a fact, is one upon which the managers of the business done in Philadelphia have a right to expect both congratulation and compliment. But the fact that any one of those cases does not result in the burning down of the city is a matter which is certainly no credit to them, but is a matter of good luck, good buildings, and good work on the part of the fire brigade. Should some hardworking firebug burn down the city some day in the course of an unostentatious attempt to realise on a small stock of highly-insured goods, the statistical argument would be useless as a defence for the insurance companies; yet there would be no change in the case as it really stands between the 
fire insurance system and the public-it might be all accounted for, not by anything that had been done or left undone by men, but simply by a change in the direction and velocity of the wind. If, as a matter of fact, insurance does breed fires, it will not do for the public to depend upon mere good fortune to check every one of those fires before it becomes a conflagration. Statistics are a great sedative, when properly prepared, but they will not restore ruined buildings or lost lives.

A compendious and useful volume is The Chronicle Fire Tables, a statistical account of the fires in the United States based upon daily abstracts of fire losses made up from the best available information. According to this work, the fire losses in the United States from 1874 to 1898 , inclusive, amounted to $\$ 2,585,186,386$, the insurance loss being $\$ 1,512,698,528$. These figures, of course, are too stupendous for us to get any sense of what they mean. They show us that, for more than a quarter of a century, the loss to the people of the United States by fire amounted to over $\$ 100,000,000$ a year. An analysis of the figures shows that the loss of late years has been over $\$ 125$,000,000 a year. This would all be a direct and personal loss to the owners of the destroyed or damaged property but for the work that the insurance companies do in distributing it among practically the whole body of property-owners. About sixtyfive per cent. of the loss is thus distributed. Mr. Edward Atkinson, who is necessarily often quoted in these chapters because he is not only a great authority upon the questions here discussed, but well and favourably known as an economist and social reformer, addressing a Philadelphia audience in 1888 , put the case in this form:

The fire loss is $\$ 100,000,000$; the cost of maintaining the fire insurance companies to distribute this loss is $\$ 45,000,000$; the cost of maintaining fire departments in cities and towns is not less than $\$ 25,000$, $000-$ a total loss of $\$ 170,000,000$, or almost fifteen per cent. of the total year's product of the whole industrial nation. It may be stated dogmatically, without 
the slightest fear of contradiction, that the fire-tax of the country is equal to at least ten per cent. of the possible savings of a prosperous year.

Mr. Atkinson gives five causes of fire loss: (I) Negligence of owners in building; (2) Want of knowledge on the part of architects; (3) Greed and incapacity on the part of builders; (4) Negligence and carelessness of occupants; (5) Incendiarism-“in less measure, in my opinion," says Mr. Atkinson, "than is generally imputed."

The Insurance Monitor, commenting on The Chronicle Fire Tables for I885, said that the figures showed that less than one per cent. of the actual destruction by fire is due to inevitable accident If this is true of other years, then the fire waste in the United States might be reduced to $\$ 1,250,000$ a year, if carelessness and crime could be overcome. Will any man who has looked at his surroundings with open eyes say that if there were no insurance, there would be as much waste through carelessness and crime as there is now when a fire may be an actual gain to the careless man or the criminal ? Mr. Atkinson says that incendiarism is a cause of fire loss to a smaller extent than is generally imputed. But he charges the laches of owners, architects, builders, and occupants with a share of the loss. If there were no insurance, is it likely that buildings would be so thoughtlessly decided upon, so badly planned, so poorly built or so carelessly occupied? Do we not know that the cost of good building and the cost of insurance for poor building are set off one against the other in the calculations of the capitalist as a mere question of money, quite regardless of what the result of poor building may be in helping on a conflagration? And do we not know that, in practice, the question of how the building is occupied, so far as the moral hazard is concerned, may be left out of account almost completely, because it does not affect the insurance rate? Exceptions to this can be quoted, but only about enough of them to prove the 
rule. That insurance does increase the fire loss is maintained by almost every authority to whom we wish to turn. In the article just referred to, the Monitor says:

As failures increase, so do fires; and, as they decrease, the fire record follows closely the same course. The simple diagram illustrating this feature speaks volumes of the close relation existing between the two.

If this requires any explanation, we find it on every side in every-day experience. But here is another remark of the Monitor itself-away back in 1876 , it is true, but particularly apposite as being written during the hardest of hard times-which sets the matter forth in plain terms:

Incendiarism and arson are evidently in the ascendant about this time, superinduced, no doubt, in large degree by the stringency of financial matters, by which many persons are compelled to realize at any cost, and see no better or more feasible mode than to sell out to the underwriters, a process much facilitated by the easy manner in which much of the adjusting of losses is done by incompetent or careless parties. Until more care is taken in both matters, so that insurance cannot be had simply for the asking, or losses adjusted and paid for effect, this class of fires will continue to grow despite all rewards for detection.

While this evil is greatest during hard times, it exists to a greater or less extent at all times. Some people understand this well enough. Here, for instance, is a quotation at second hand from a newspaper in Little Rock, Ark., reporting the opinion of a fire brigade on this question. The name of the town is given, but not the State. The clipping is from The Weekly Underwriter:

We, the volunteer fire department of the city of Newport, protest and condemn the insurance companies doing business here, in giving excessive insurance to parties without first inquiring into their moral character, and a thorough and previous inspection of the property insured. The result of this negligence on their part has made insurance a 
speculation, and has created a spirit of incendiarism, for which the insurance companies are responsible, and we, the fire company, and other citizens, suffer by this reckless and wanton mode of doing business.

A most just and reasonable protest, coming from men who, voluntarily and without pay, give their time and risk their lives to save the property of their fellow-citizens. It is bad enough to lose time and risk life in suppressing inevitable fires, but to be kept on the qui vive by the nefarious acts of a lot of firebugs, bribed to their horrid work by the ever-present hope of realising insurance money, is simply outrageous and intolerable. And those whose property is put in danger of destruction by these criminals have an almost equal right to demand reform.

Just what the proportions of this evil may be, it is not easy to say, for incendiaries have not yet been licensed and required to report their operations to any public official. On this subject, however, as on any other, it is easy to give figures, for, nowadays, the statistician is all-pervasive and nothing that is written about is neglected by him. But, as usual, all statisticians do not agree, and so we are free to make a choice. I purposely put aside the highest estimates of the loss occasioned by criminal and criminally careless people whose reward is insurance money. Not that I believe those estimates exaggerated; but it is better to keep well within the mark than to have one's statements called in question. And the facts even according to the lowest estimate are bad enough.

In the article in the Monitor in which it is stated that the inevitable fire loss is only one per cent., an estimate is given that thirty per cent. of the fire waste for the whole United States is due to criminal causes, and that in some States the incendiary bill actually runs up to fifty per cent. But, of course, there are other causes of incendiarism than a desire to defraud an insurance company. As to the proportion of incendiarism arising from different causes, we find estimates 
made by insurance people and others. The fire marshal of Boston, for instance, gives figures on this branch of the subject. In his report for 1889 he divided incendiary fires into four classes, according to the motive, the result being as follows: Revenge, 28 per cent.; "Deviltry," 25 per cent.; "Pyromania," 7 per cent.; to rob insurance companies, 40 per cent.

Thus we see that, while we have reason to fear that onethird of the whole fire waste is actually due to incendiarism, we have reason to fear also that two-fifths of that one-third is due to a desire to rob the insurance companies. Assuming the fire waste at $\$ 125,000,000$ a year, we find that not less than $\$ 14,000,000$ a year is lost in the United States alone as a result of a faulty system of fire insurance. Of course, it is not pretended that the system can be made perfect and this waste wholly prevented; but surely it will not be pretended that the loss of this enormous sum is inevitable.

And these figures, be it noted, apply only to the loss through plain, deliberate torch-setting, the kind of thing for which, in some communities, men are lynched on sight, and, among civilised people, are sent to jail for long terms. But there are other ways of setting a place afire for insurance money than by hiring a match-and-kerosene artist. These methods may all be summed up in the word "carelessness," if we include the idea of criminal carelessness with more or less design in it. At one time in the history of fire insurance in the United States, farm risks were supposed to be the very best kind that could be had. "Non-hazardous," they were called. The farmers were generally insured lightly or not at all. They were making money, for prices were high and the soil they tilled was fertile. Desiring farm risks, the insurance companies competed for them-competed in the blind and senseless way so often characteristic of incorporated companies of every kind. Rates went down, and the farmers were urged in every way to increase the amount of their insurance. The effect was, of 
course, to cause many places to be insured for their full value or more. There came a sudden change. The farmer of the Eastern and Middle States could no longer grow grain in competition with the great operator on the cheap and virgin lands of the West. But the Eastern farmer did not learn at once that the object of the Genius of Political Economy was to make him a market-gardener and dairyman. Not understanding that he was to change his occupation in this manner, he continued to wrench from his partly-exhausted land such grain as it would yield and to team it to a demoralised market. The result, of course, was that the value of farms went down, and the farmers endured the worst kind of financial weather. Farm fires increased, and many a man was saved from the attentions of the sheriff only by a fortunate conflagration that swept his land clean of old buildings and brought him a thumping check from the insurance company. Such fires, in but few cases, I believe, were caused by direct incendiarism; but I believe also that many, even the majority of them, were caused by carelessness, "superinduced," to use the words already quoted, "by the stringency of financial matters." In putting up his stove, in instructing the hired man how to handle his lantern, in the use of matches-in countless ways-the farmer who stood to gain by fire was less careful than he had been in the days of great prosperity and little insurance, when a fire would have meant not benefit but ruin. All this stands to reason, and the reasonableness of it was proven by the increase of farm fires. It grew so bad in some sections that the insurance men began to regard "farmer" and "firebug" as interchangeable terms, and actually refused to insure farm buildings or their contents at all.

This was only a temporary state of affairs. Somewhat similar cycles have occurred in other lines of fire insurance. But, besides these special cases, we have a constant cause of loss in the carelessness or worse of all kinds of people who are 
insured and who find it advantageous to realise upon their policies. Through this leak in the purse of the community run millions upon millions every year. In the regular course of events, a method of making money which continues in use year after year has a constant attraction for those who are best fitted for it, and tends toward sub-division and specialisation, like any other trade. To say that there are those who devote themselves to the business of setting fire to houses for the purpose of swindling insurance companies, and that too in great cities where any fire may mean a conflagration, would seem like a grotesque and fanciful lie. But, if we are to believe what those who pretend to know tell us, we must believe not only that, but also that this business is highly specialised, those who follow it recognising the different branches just as we recognise the differences between a compositor and a pressman.

If a man were found poisoning the source of water-supply for a city, he would never receive a trial-the people would tear him to pieces. Yet such a man, one would think, would be an innocuous person compared with one who devotes himself to the business of starting fires, any one of which may result in awful catastrophe. Among insurance men, the firebug is recognised as a fact, and is counted upon as an element in the risk. Moreover, it is known and recognised that the most persistent, cunning, and dangerous firebug is not he who burns down houses for revenge or through pyromania, merely for the pleasure of watching the fire and seeing property destroyed, but he whose object is to get insurance money. It is by no means uncommon to read of the doings of gangs of this kind, but the ordinary citizen merely reads and forgets, not only losing the facts but avoiding the lesson which the facts teach. In a journal called The Western Fireman, one of the best of the periodicals devoted to the interest of members of fire brigades, appeared an account-this was in 1897-of a wave of incendiarism that had swept out of existence much property in 
Cleveland, Ohio. The charge is made that insurance agents in some cases had leagued with the firebugs, and cases of overinsurance are quoted to prove it. Several gangs of these criminals have been unearthed in New York. One was headed by a woman named Silbermeister, and another by a man, one Schoenholz. There was no trustworthy means of learning how much property they had destroyed, but it was clear that their operations had been very expensive to the insurance companies. The following article from a New York daily newspaper, which I find quoted in The Insurance Monitor, will give an idea of how these firebugs operated-and are still operating, no doubt, for you do not put down any kind of crime merely by detecting some perpetrators of it and sending them to jail:

The offer of $\$ 1,000$ reward by the National Board of Fire Underwriters last month for the conviction of the incendiaries in the case of Samuel Levin, the Brooklyn clothing dealer who was burned out in January last, led an adjuster to give the following account of the operations of the incendiary gangs in this city and vicinity to the New York World.

"In the first place," he said, "you want to understand that the professional firebug is one of the smartest and cutest of criminals. We understand their operations thoroughly, but it is almost impossible to convict them. If one man or two were involved, it would be comparatively simple, but these people have a regular gang, with sometimes as many as a dozen persons in it. They have their principals, their dummies, and their lawyers, too."

"How do they begin operations?"

"The first thing is to get a store. Then they stock it with cheap goods and apply for insurance. After they get all they can, they move in more goods. This is usually done on Saturday evening, not too late at night, but between seven and eight o'clock. The goods are unpacked and spread out on the counter or shelves. The next day, Sunday, there is a fire."

"Why are the goods taken to the store at night?"

"Because they are second-hand or damaged. The adjuster cannot tell, after the fire, whether the goods were damaged by the fire or not. Then they produce books, invoices and receipts to show the amount of stock 
they had. This is the way the gang works. One man will rent a store. He may also apply for insurance, ordinarily through a broker, or he may get a friend to do it. Then another of the conspirators will help him out by sending a receipted bill of sale for goods. In clothing stores the goods are nearly always second-hand and of the cheapest kind. I met with one case where one of the firebugs who, I know, belongs to one of the gangs, put in a bill for a lot of cloaks. On examining the cloaks that were saved from the fire, I discovered that all of them were unfinished. Many of them did not have the sleeves in, and the bastingthreads were still there. These cloaks had been purchased at a sale of damaged goods, from a cloak factory that had been burned out.

"Another thing which makes it hard to reach the firebugs is the aliases they use. They arrange to have the changes in the name slight only. A firebug may retain his family name and change only his given name. Sometimes he will call himself Samuel, and then Peter, and then Jacob, and so on. Again, the family name is spelled differently, though a similar pronunciation is maintained. For example, the papers all published the fact of the arrest some time ago of a man named Warschauer and his wife. They were arrested for burning down their store. Now, we have on our records several fires in stores owned, or said to be owned, by a man named Warshor. The men are identical.

"There is still another end to the conspiracy. There are in New York scores and scores of shysters who call themselves public adjusters. In a great many cases these men are simply members of a gang of firebugs. An alleged hat factory burns down, and forthwith a clerk in another factory appears on the scene as an adjuster. It is the same thing in other lines of business. The adjuster stands in with the firebugs."

Cases that have been unearthed show that there is still another end to the conspiracy. Wholesale merchants of good reputation-not of very good character-furnish such invoices, receipts, and other vouchers as may be needed by parties who are arranging a fiery raid upon the treasury of an insurance company. In The Insurance Monitor for January, 1892, appears an account of such a case. A claimant demanded from the insurance company payment for goods valued at $\$ 1,500$ which had been destroyed. He produced invoices showing the 
purchase of $\$ 8,000$ worth of goods. The insurance company, being suspicious of attempted fraud, referred to the wholesale merchants. The wholesalers corroborated the statements of the claimant, and showed entries in their own books in attestation. Further investigation, however, convinced the adjuster that this was a systematic and elaborate fraud. Strangely enough, the facts are used by the editor of the Monitor, not to read a lesson to the companies to be more careful about the parties to whom they grant insurance, but to advise them, in suspicious cases, to call for bills of lading and other original and not easily counterfeited documents, with a view to resisting the payment of a fraudulent claim. This would be quite satisfactory to the insurance company, but if, in preparing this fraudulent claim, the insured has burned down not only his own place but several blocks of other buildings, the successful resisting of the claim does not complete the happiness of the public. If the insurance company regards this as a matter with which the public has no concern, it should, in fairness, arrange to have the destruction confined to that property in which the company and the firebug alone have an interest. If they cannot or will not do this, those outside of the transaction who are so directly and disastrously affected have a perfect right, not merely to condemn the incendiary, but to hold to account the other party whose carelessness in doing business offers, as a matter of fact, a bribe to the incendiary to burn down the houses of fifty of his neighbours.

After one more citation, we may turn to a consideration of the working of the system in other countries than America. In The Forum for February, I895, appeared an article on "The Barnacles of Fire Insurance," by Mr. Louis Windmiiller. It is an admirably clear and forcible presentation, in synopsis, of the case. Mr. Windmüller does not shirk the main point-that fire insurance increases fires-nor does he minimise the effect in this direction of the system of paying 
agents by a commission on the premiums. One case that he recites had not come under my notice. If the agent of whom he tells was not insane, the incident is striking proof of the extent to which commission has ruled the business at times. Says Mr. Windmüller:

Agents are sometimes so anxious to secure commissions that they will accept doubtful risks even from strangers. In Boston, a notorious woman already convicted of incendiarism had been suspected of planning a similar crime. While she was under the surveillance of a female detective, to whom she had confided her scheme, the Boston agent of the same company she expected to defraud and who had employed this detective, accepted her application for an additional policy of $\$ 500$ on the very property she wanted to burn in a few days !

Mr. Windmüller notes that the companies employ salaried travelling agents to inspect and control risks, but says, very justly, "it is difficult to form a correct opinion of the hazards surrounding each venture in the short time the special agent can devote to each place." This must be particularly true when the determination of the travelling agent to cancel a given risk may mean a good many dollars deducted from the income of the resident agent. In fact, when two employees of the same company are employed to do a given thing in two different ways, it is not at all certain that it will always be done in the best way. This writer speaks also of the looseness and fraud which characterise the settlement of fire losses. "From the assured down," he says, "every person in any way connected with a fire seems only to study how much he can make for himself out of the fire underwriters." In short, Mr. Windmüller comes to these conclusions:

The business as now carried on (I) encourages idleness by paying more for service than it is worth, (2) offers a greater indemnity for goods which have been burned than their previous value and thus encourages their destruction, and (3) it is hedged in on many sides by corruption and fraud, to an extent which must engender immorality. 
To what extent the business of incendiarism for insurance money is carried on in Continental Europe, or how far fire losses there are increased by this form of fraud, I cannot say. I find it often stated that fire insurance rates are higher in the United States than in Europe, indicating that the fire loss is less and, prima facie, favouring the conclusion that insurance has not so great an influence in causing loss, as it has on this side of the Atlantic. But the experience in Great Britain goes to show that this evil is by no means confined to one country. This subject-like almost every other subject that one can think of-has been investigated at the instance of the British Parliament. This time the investigation took the form of an inquiry by a Committee of the House of Commons, the report being presented in 1867 . The Committee informed the House that most witnesses agree that there had been a great increase of fires in late years, and a large proportionate increase in the fires whose causes were unknown. Mr. Sidney James Fletcher, secretary of one of the largest insurance companies, stated his impression-the result of fifty-two years' experience in the fire insurance business and of special attention to this particular subject-that nearly one-third of the fires which occur are intentional. Cheering information for the Londoners of that time! The report says:

Evidence was also given stating that the rate of increase in the number of fires in the metropolis since 1835 was much greater than the rate of increase in the number of houses or the rate of increase in the population. It was also stated that of 589 fires in the metropolis during 1866 whose causes could not be satisfactorily accounted for, 480 , or about fivesixths of the 589 , happened to be on insured property. It has further been given in evidence, and admitted even by gentlemen connected with insurance companies, that the increase in the number of fires in late years is in some measure to be attributed to the great competition among insurance companies for business; to their carelessness in taking risks as well as in the appointment of agents; to the too ready facility with which they settle claims, some of which they believe to be fraudulent, 
and to a disinclination in general in the companies to prosecute. The reasons given for this disinclination to prosecute on the part of the insurance companies are the great difficulty in obtaining evidence, the unwillingness of the people to come forward to give evidence, the want of proper means for compelling them to do so, the prejudice existing in the public mind and in the minds of juries against public companies prosecuting private individuals, the unpopularity to which a prosecution exposes them, and the uncertainty of the result.

When they come to recommend a means of curing the evils thus exposed, the Committee suggest several improvements in the laws or regulations respecting materials and methods of building; but they add that they "still are of opinion that the large number of fires whose causes are unknown or suspicious would not be much affected by such recommendations." The report proceeds:

On referring to the evidence, your Committee find that wilful fireraising is traced to several sources: First, to individuals and organised gangs of men who make a trade of it to defraud the insurance companies; second, to individuals who have been unfortunate in business and who cannot meet the claims made on them; third, to persons in warehouses, to conceal theft of goods made by them on the warehouses; fourth, to malice.

As a first step toward the suppression of all these classes of incendiaries, the Committee recommend more stringent inquiry into the causes of fires, outlining a scheme to that end which it is not necessary here to go into. But they add that, "they would specially recommend that no claim should be settled by an insurance company without the certificate from the police or fire brigade or the officer appointed to conduct the investigation into the origin of the fire; but this certificate should not debar the insurance office from opposing the claim if they think proper."

Many quotations from the evidence are made in the Committee's report, but some of the most important for our present 
purpose must be sought in the report of the evidence itself. Mr. Fletcher, who has already been referred to, told of one man who had been guilty of setting fire to no less than sixty different houses. When this man was captured and sent to prison, there were no more fires in the neighbourhood in which, up to that time, he had carried on his operations. The superintendent of the salvage corps testified that he knew of a man who had lived entirely by setting fire to houses. This enterprising scoundrel played the game for the last penny that was in it. He would lease a dwelling for his own occupation, and would move in his household goods in the ordinary way. $\mathrm{He}$ would then insure the furniture for as much as he found advisable. After a time he would surreptitiously remove the goods and set fire to the empty house. When the job was complete, he would file his claim and draw his money. He had actually played this trick successfully six times in one year. Would it have been unreasonable if the managers of the insurance companies, who thus carelessly kept a criminal of this kind in their pay, had been called upon to resign the positions they so inefficiently filled and even to share the legal punishment meted out to this side-partner of theirs?

Au assessor-adjuster of claims as he would be called in some places-declared his opinion that fifty per cent. of the fires that occurred were of incendiary origin, the "sufferers" in many cases being small shopkeepers who were on the verge of bankruptcy. Very often, when a fire was quickly extinguished, the goods saved were found to be "dummy" goods, while the naphtha-soaked floor, the piles of papers and other inflammable rubbish scattered about, and evidently intended to help on the fire, bore mute but conclusive testimony to incendiarism. Even where the fire arose through carelessness, if the person whose property was threatened was insured and was in need of money, he took no pains to extinguish the fire or save the goods. But the insurance policy, said this experienced and observant wit- 
ness, was always preserved. He said also that there was " no more ready market than a fire for unsalable goods."

A bill was introduced in the House of Commons embodying the principal recommendations of the Committee; but the Government never adopted it, and it never was passed by Parliament. The records of the House of Commons show that, from time to time, spasmodic efforts have been made to revive public interest in the matter, but with mournful lack of success. So eminent a man as Sir William Vernon Harcourt, who was afterwards Chancellor of the Exchequer and who succeeded Mr. Gladstone in the leadership of the Liberal party, stated, in 1882, when Secretary of State for the Home Department, that one of the reasons why the Government would decline to introduce a bill on this subject was that "when an ordinary fire takes place, the officers of the fire brigade report upon the circumstances, and the insurance companies have a clear interest in investigating the matter." No doubt if some firebug, in the course of business, and in a painstaking attempt to win $£ 50$ for £io worth of goods, should start a second Great Fire of London, this eminent statesman would tell his political friends and the country to rest content-that the chief of the fire-brigade and the manager of the insurance company would have the offender reproved and admonished to be more careful in future. If the eminent Sir William Vernon Harcourt had wished to say that this was a matter which could not be advantageously dealt with by legislation, his opinion would be worthy of all attention and consideration. But to suggest, as he did in the words. quoted, that in these matters, involving none can say what interests, the public should be content with an investigation which could lead to nothing more practical than the jailing of the incendiary, was simply to show that he had not given the subject a moment's thought. And yet, this is not a small matter; it is a matter which even so great a man as a Secretary of State for the Home Department and future leader of a great 
party might well take time to think over. If the reader thinks the subject important enough, I will ask him to follow me in another chapter-a short one-that we may consider the facts we have already collected, their relation to one another and their bearing upon the interests of society. 


\section{CHAPTER IX}

\section{FIRE INSURANCE-Concluded}

The Need of Reform-Demoralisation caused by Abuses of the SystemIgnorance of the Subject on the part of those who Make and Interpret Laws-Public Sentiment can Directly Cause Improvement.

$\mathrm{W}^{\mathrm{H}}$

HEN it is proposed to make any change in human affairs, objections are raised, for people dislike-naturally and rightly - to be obliged to adapt themselves to new ideas and new ways. That objection which is usually the first, as it is the hardest, to meet-for it rather provokes the reformer to useless rage than to effective argument-is that we cannot expect perfection in mere human institutions, and that we must take the bad with the good. The argument is a good one, if the philosopher who presents it is willing to stand by it. Let us suppose that the plumbers in his house have made a mistake or have scamped their job, the result being that the drain-pipe, instead of carrying filth out of the house, carries into the house the foul gases that fester in the sewer, and two of the philosopher's children die of diphtheria. How handy it will be for him to be able to reflect upon the imperfection inherent in our mortal state, and how consoling to know that we must take the bad plumbing with the good. Such an argument is so fine that we should not spoil it with common handling-we should leave it to the philosopher who uses it, while we common people seek to change things about us so as to fit them to yield us a maximum of good with a minimum of evil.

When we find that fire insurance companies in the United 
States alone, according to figures which we have a right to believe to be the reverse of exaggerated, distribute $\$ 14,000$, 000 a year to incendiaries as a reward for destroying their own and others' property, it is worth while to consider whether it is not possible to invent a system of fire insurance that will do the proper work of insurance without maintaining a vast army of dangerous criminals. When we find that fire insurance adds to the terrors of hard times by offering to every man in diffculties a way out, a way that he may tread only by placing in jeopardy his neighbours' lives and property; and when we find that, according to the spokesman of the insurance companies themselves, that way is followed so often that there we must search for the cause of more than half our fires,-surely it is not too much to say that patience with such a system not only ceases to be a virtue but becomes a vice, a crime, and a disgrace.

The danger of fire is always bad enough, but surely it is appalling to think that, mainly in the big cities where the peril is greatest, there are men-hundreds of them-who are, in effect, hired by the insurance companies to set houses afire. And these fires, be it noted, are not usually set in the uptown districts, where streets are wide, buildings good, and their occupants thrifty and careful; but in the crowded districts, where secondhand stores abound, where the "rookeries" are, and where the people are poor and, too often, shiftless. It is not impossible that some of this fire-raising fund may be earned by a man who will raise a fire just at the wrong time. No New Yorker who is old enough to have a clear recollection of his city on the 13 th, I 4 th, and I 5 th of March, I888, is likely ever to forget that occasion. An unexampled blizzard reduced the city to a state of siege or worse. Communication by conveyance, messenger, or wire was practically suspended. Suppose some such cataclysm complicated by a fire in the little shop on the ground floor of a poorly-built and crowded structure. The fire-brigade might as well be engaged in forming a Browning club as in 
waiting to learn of such a fire, or in attempting to reach it when they had learned of it, or in trying to put it out after they had reached it. A favourable wind - favourable to the fire, of course-would mean the sweeping away of half the city. It may be said that it is most unlikely that such a combination of the elements will ever arise. True. But is it worth while to spend millions of dollars every year in hiring men to see to it that when the other elements $d o$ combine in this manner, the fire shall be there to make the disaster complete? It is not likely that a man could set fire to a house by using only a flint and steel against the veneering planks. But what would be thought of the man who, because it was unlikely, hired an expert to keep on trying it ?

The professional firebug is the most striking, not to say startling figure in this case; but, all in all, he is not the worst. For every dollar that goes to the professionals, two dollars go to the men who are simply careless. I appeal to the reader, no matter where he may live, if I do not speak truly when I say that in every town there is at least one man who has had a profitable fire and is generally believed to be not too careful about avoiding another. Consider, for a moment, what this means.

Here are two men in the same trade in the same town, both working along, making a fair living and a little over. Hard times come; custom falls off, profits are cut to the bone, and credit becomes more limited. The struggle grows keener, and, at length, both men begin to look with dread to the future. When things are at about their worst, one man's place is burned down, and the "sufferer" draws money from the insurance company. He then sells off his damaged goods at a demoralising sacrifice, and stocks up with new, clean goods, thus gaining the double advantage of injuring his competitor and benefiting himself. The other man must face "taxes and botherations," to use Carlyle's phrase, without outside assistance. And, of 
these taxes and botherations, one of the most trying to a man who knows that fire can almost certainly be avoided, if due care is taken, is payment for fire insurance; for he feels that a share of the money taken from him goes to reward criminal and careless persons. But to ask for a lower rate, would be a hopeless request. The insured must deal with a local agent, who must deal with a general agent, who must deal with a manager or president, who must deal with a board of directors, who, it may be, must deal with a rate-making association of which the company is a member.

Is it not as clear as anything can be that a man so circumstanced will be tempted to neglect precautions against fire?to protect himself by increasing his insurance rather than by maintaining his vigilance? Will he not be likely to prepare for a fire by putting unsalable goods where they will be most likely to burn rather than by placing inflammable goods where they will be farthest from danger? And, if a fire occurs, will he not stretch his conscience as far as he can-and, with a good object and hard trying, it is wonderful what the least skilful of us can do in this line-in making out his claim? This is not one case alone; it is not an imaginary case. These are the concrete facts which millions of men must face during the hard times. These constant temptations overcome the scruples of many, and even those who resist must feel that they would rather have their virtue bulwarked by more favourable circuinstances. Those who wish well to their fellow-creatures should do what they can to have these temptations removed. We are taught to pray not only to be delivered from evil but to be kept from temptation. Scoffers tell us that it is a poor class of virtue that is never tempted, but even that scoffer will turn sick when he sees a friend foolhardily venture near a precipice. And those who are not scoffers realise that he who suffers temptation to face another when it can be prevented is not wholly without $\sin$ if that other yields. 
We do not realise how far back this demon of carelessness begins his evil work. This was referred to in a preceding chapter, but the point will bear further consideration. We have seen how, in respect of marine insurance, the learned and dignified bodies that investigated the matter found that there were faults in the designing, building, rigging, finding, manning, loading, and sailing of ships. But the best man of all these commissions, when he came to deal with the matter, proposed the one single reform-a reform which would have the effect of leaving the shipowner to suffer by the loss of his own property. In the same way here: if a man did not know that he could cover up bad designing, careless construction, poor material and scamped work, with an insurance plaster, which plaster costs about the same whether the building is good or bad architecturally-if he did not know that it would make little difference how the building was occupied, so far as the character of the tenant is concerned, would he not make sure of having a good building or leave the making of buildings to those who understood the business? Would he not make sure of the character of the tenant or keep his building unoccupied?

Faulty electric wiring, the unguarded handling of kerosene, the careless use of matches, criminal disregard of danger from cigars and pipes-these and many others are purely modern dangers. Our modern methods of working and our modern architecture have not kept pace with the multiplication of causes of danger. Being insured, each of us has found it cheaper to burn than to take care. This is very well in individual cases. But, when we analyse the results, we find that the advantages go to firebugs and careless people, while the money is taken from those who obey the law and have a decent regard for the safety of their own property and that of their neighbours. A man like Ruskin could make a fine argument, I believe, in support of the proposition that insurance, by 
tempting us to botchwork in architecture, has misled us into following the ideas of other times instead of fronting the building problems of our own time and following original lines to such solution of those problems as shall combine usefulness with the highest beauty. Before the reader pooh-poohs such an idea, let him ask himself the question whether the house of the modern man of civilisation is as well adapted to his actual wants as is the tent of the Bedouin to his wants. I can reason, a priori, that insurance would have the effect I describe, but I have not the knowledge of building and architecture to enable me to put a foundation of facts under even so pretty and promising a theory. I do know, however, and have proven, that fire insurance, while it does good in making the business of the individual secure, has introduced into the business life of the community elements of insecurity which could not otherwise exist. Should the reader not be satisfied with the proof I have given, he need only read a file of any insurance journal that gives fair attention to fire business, or consult the works of any author who has written upon the subject.

The same old question then arises: What are you going to do about it? In such cases, the appeal is generally to the legislator for laws to compel people to follow a course believed to be desirable. The faith of the modern man in the power of the statute law and the policeman's club to accomplish everything, from the preservation of school-children's teeth to the building of an empire, seems to be unbounded. I confess that I have not so great faith. There are some things that the law and its officers cannot accomplish, but there is nothing they cannot spoil. Even when a law is honestly drawn and honestly enforced, it may do harm instead of good. While I by no means join in the denunciation of politicians which, in some quarters, is so fashionable, neither do I believe that the fact of a man being a legislator or an officer of the law endows him with a complete understanding of the technique of every busi- 
ness, or makes him wholly proof against the faults and frailties of our humanity. Fire insurance, it is true, is not so complicated a business as marine insurance; but it is quite complicated enough to be easily misunderstood, especially by one who has not been brought up to it. One of the most curious things in our modern life is that lawyers - the people who practically make and actually enforce all our statute laws-do not understand insurance. There is no belief more firmly embedded in the insurance man's mind than this-that if he goes into court to fight a case, he is as likely to find his lawyer arguing against him as for him. Not because the lawyer is unfaithful, but because he is so often unable to get it through his head that in taking up an insurance case, he is dealing not with an ordinary, but with a special contract. Here, for instance, is an article from The Insurance Monitor for April, 1878, entitled "Why the Companies are Defeated in the Courts," which says :

The unfitness to try an insurance case of the average lawyer who is versed only in a general practice will be attested by all insurance men who have undertaken to coach one of these attorneys during a trial. Over and over again, we have heard the stereotyped complaint, "We could not make our lawyer understand our case." This is not the wail of the man who is beaten in the courts but will not acknowledge that he is wrong; it is the complaint of the man who could not get his case, be it good or bad, put before the court in understandable shape, and who for all practical purposes, might as well have been absent and wholly unrepresented.

The effect of this ignorance on the part of those who make and who enforce the law is plainly to be seen in the record of the laws concerning insurance in the several States of the Union. I cannot go into that subject, for local knowledge would be necessary to discuss even generally any given case. Besides, if that work is to be done, it should be done in a separate book-and a big one. Suffice it to say that laws of every 
imaginable kind have been proposed, and some of the most fearfully and wonderfully made of them have actually won places on the statute books. Yet the fire waste goes on; the incendiary is at work; and the cry goes up from the insurance companies for higher and higher rates to cover their heavy losses.

On the other hand, if, as there is reason to believe, the fire waste in countries of Continental Europe is less than that in the United States and Great Britain, this fact, coupled with the closer regulation of such matters in Continental countries, makes an argument in favour of better laws and a more rigid enforcement of those laws. Just what laws can with advantage be passed, and just what means should be taken to carry them out, are questions worthy the attention, it seems to me, of those whom it may concern. But, while I do not presume to suggest anything positive in the way of amendment of the statute law, I venture the remark that past experience may indicate the need of caution in anything that is to be done. The British Commission on Unseaworthy Ships (1884-87) found that the Plimsoll-inspired laws had not suppressed the evil, but had only "marked out a territory within which it is safe to operate." An untrustworthy protection only promotes an unwarranted feeling of security and thus adds to the danger.

Meantime, public sentiment can do much, even unaided by the law. If the public can be made to realise that, in practice, good men and bad men-those who are often burned out and those who are never burned out-are insured at the same rate, the feeling of justice which is innate in the people will cause them to demand reform. This reform, it seems to me, must work in the direction of insisting that the insurance companies shall charge for risks as they are, and not as they may be represented to be by partly-interested persons. Here, let us say, are two men in the same line of business and occupying buildings equally good as to situation, material, and other qualities mak- 
ing up the physical hazard. But one man is conscientious, orderly, successful, and popular, while the other is on the verge of bankruptcy, with not too good a reputation, and having some bitter and unscrupulous enemies. Is it not perfectly clear that the second should pay for his fire insurance at least ten times as much as the first? Is it not outrageous that they should be charged the same rate? The fire insurance man may say that he would not insure the second man at any price. But he will not tell you that that man is not insured. Nor will he tell you that that man pays a higher rate than the other pays. The "other agent" has written the risk and collected his commission. This may exonerate the good agent. But there never was any question about him, for he will do good work regardless of the system under which he works. Nor, for that matter, do we call in question the bad agent. Our quarrel is with the foolish and criminal abuse of a system which is good in itself and which, properly used, is capable of yielding us incalculable good with a minimum of evil.

It will be said that if the thriftless man were charged a very high rate it would be such a discrimination against him that it would force him out of business, and that the effect of the change would be to make the insurance people the final arbiters to decide who should remain in business and who should be driven out.

All this does not exactly follow. The thriftless man can pay the extra premium if he pleases, and so remain in business. $\mathrm{He}$ is paying only for his own folly, incapacity, or bad luckand there is nothing unjust or unreasonable in that. Or, if he prefers it, he can reform. He can show capacity and willingness to take care of his own property, and so refrain from endangering that of his neighbours. If he will not reform, and cannot pay the price that is fairly demanded from his undesirable class, surely it is better that he should be forced out of business than that he should remain to bedevil the commercial 
life of the community. The man is not fit to be in business. Let him go and break stone, or write books-let him enter the ranks of labour in that company to which he naturally and honestly belongs and cease to endanger the lives and property of a townful of people.

The editor of the Chronicle Fire Tables for I 895 says: "The way to reduce fire-insurance rates is to reduce the fire loss." This is true. It is likewise true that the way to bridge a chasm is to lay across it a plank or structure of planks or other rigid material sufficiently long and sufficiently strong. In the good old story, the Irish labourer assured the farmer that he could hold a plough and was engaged to break a field. And when the farmer indignantly reproved him for a palpable misrepresentation, as proven by his utter failure, the Irishman, with equal indignation, demanded to be told how he could be expected to hold a plough with two horses pulling it away from him. Putting aside all feeling that may tend to mar the amenities of debate, we may fairly ask, Mr. Editor, how it can be possible to reduce the fire waste when the insurance companies offer and pay standing bribes of millions of dollars of good people's money to induce bad people to burn down their own property and that of their neighbours?

The insurance people may tell us that it impossible to change the present system, and may quote the opinions of generations of professional bigwigs to prove it. But we know that the doctors told us that consumption was incurable and invincible; we know that railway men told us that the slaughter of brakemen was inevitable; we know that weaklings of all ages have told us that honest government was impossible. If the insurance men tell us that this burning down of ninety dollars' worth of property is necessary in order that the losers of ten dollars worth of property through really accidental fire may be indemnified, the question naturally arises whether it is worth while to pay so much for so little. The experience of 
the Mill Mutuals of New England shows that property can be protected and its owners indemnified for a very small charge. If the present insurance system were done away with, the New England system or some other would be adopted.

For insurance men to say that the present condition is a necessary and inevitable outcome of insurance, is for them to defame their own great and noble profession. What we see is not the fair working of the system, but abuse and misapplication of it. One way out of the quagmire, and the quickest and best, I am convinced, is to pay the local agent in such a manner that it will be to his interest to make his agency profitable by his own work, and not by means of a great combination of companies forcing up rates to a point that will clear not only necessary expenses but unnecessary and wasteful losses. At present, a man who has failed in every other business can easily secure an appointment to represent a fire-insurance company. This would be ridiculous were it not so serious. Now, the managing of the local business of a fire-insurance company is not a fool's business; it is work that calls for skilful and painstaking service. But what encouragement is there for a man to serve an apprenticeship to the business, to acquire a knowledge of buildings and their contents, and to make himself master of the circumstances making up the moral hazard in the case of every man in the town? What the companies pay for is, not the knowledge that will bring a fair profit with fair rates, but the "hustling" that will bring a big business at the rates that can be forced upon the people. Even if a man learns the business honestly and uses his knowledge honestly, he may be pushed aside at any moment to make way for the shallow, ignorant, but magnetic canvasser who knows no more of the nature of the contract he is making than the average book-agent knows of the contents of the twenty-volume Shakespeare he presses upon an inattentive public.

The root of the difficulty, after all-just as in the case of the 
alleged incurable consumption, the doomed brakemen and the corrupt politics already referred to-is that " the people love to have it so." So long as the great public is willing to be charged high rates to make up for the lack of will or the lack of ability on the part of insurers to learn how to make their business more of a blessing to the community, so long will the present state of affairs continue. Let public sentiment be once aroused on this matter, and the reform is accomplished. 


\section{CHAPTER $\mathrm{X}$}

\section{LIFE INSURANCE}

Nature of the System-Its Growth in Recent Times-Importance and Adaptability-How Abuses Arise-Supreme Importance of Maintaining a Pure Life-Insurance System.

" THE days of our years are threescore years and ten; and 1 if by reason of strength they be fourscore years, yet is their strength labour and sorrow; for it is soon cut off, and we fly away."

"Skin for skin; yea, all that a man hath will he give for his life."

In these utterances, one of the Psalmist, and one of that Satan who suggested the afflictions to which Job was afterwards subject, we have two of the main pillars of life insurance. In dealing with questions which are essentially and directly those of life and death, we enter upon territory different in nature from any other with which insurance has to do. Property can be measured by property; but honour, duty, love, are the only terms in which we can estimate the value of life, and these things themselves have no market.

When we see this in its true light, we see that "life insurance" is a misnomer. In any true bargain of the sort that is ordinarily called by this name, that which is insured is not life, or any phase or portion of life, but only the money value of one person's life to another. If a man without property owes another a thousand dollars, the payment of the debt clearly depends upon the continuance of the debtor's life until 
he shall have acquired the money. While no man knows how long he or any other man is destined to live, yet there are those who know, to a fraction, the average length of life of the healthy male of a given age, class, and place of residence. With this information, it is quite possible to arrange a club of such people, so that by paying in a lump, or in instalments, a certain sum, there will be a fixed sum ready to be paid to the representatives of each man as he dies. This arrangement is necessarily dependent upon the duration of human life. Upset the law that each man values his life above everything that can be offered in exchange for it, and you shorten the period of life on the average, and so remove the very basis of the calculation. In that case, instead of dealing with the most certain of human affairs, you find yourself dealing with the most uncertain.

The law of insurance, that it merely indemnifies for lossnot loss of the object of affection or ambition, but financial loss calculable in terms of hard cash-presupposes that the life of the person who is the subject of the insurance shall not be insured for more than its money value to the person in whose favour the insurance is made. If the amount insured is greater than this financial interest, then, to the extent of the overplus, the beneficiary has a financial interest in the death of the insured. This does not necessarily mean that, in order to secure the overplus, the beneficiary will at once put strychnine in the coffee of the insured; but it does mean that the weight of interest, whatever it may be, is on the wrong side of the balance. The law is that we should love our fellow men; and to offer a bribe, however small and however ineffectual, to one to shorten the life of another, is contrary to that law. If life insurance necessarily offers such a bribe, then life insurance is necessarily a thing of evil. But we in modern times proceed upon the theory that such is not necessary and that life insurance is not to be condemned on that ground. On the other hand, by making certainty where there is, otherwise, uncertainty; by enabling 
one in life to provide after death for those who are dependent upon him and whom he cannot otherwise provide for, life insurance is a good thing.

It is said by a certain school of economists, and also, on different grounds, by a certain school of religionists, that life insurance is not the best or the true way to attain the object in view. Without attempting here to argue that question, we can at least say that it is the method which commends itself to the modern man, as proven by the extent to which it is used and the rapid increase in the number of those who use it. Just as the railway train may, some day, be superseded by the flying machine, so life insurance may be made unnecessary by the establishment of some far better system. But, in the meantime, men endure dust, cinders, noise, crowding, and other inconveniences for the sake of the advantages they think they gain in travelling by railway. And so they accept life insurance for the lack of something that seems to them better.

The above remarks are by no means profound, nor are they strikingly original. But it seems to me that something of this sort-I wish I could have said it better-is necessary in order to mark the change from the subjects we have been dealing with to the one to which we now turn. Hitherto, we have been dealing with property simply, and any question of loss of life was merely incidental. If a ship were scuttled and the crew went comfortably ashore in the long-boat, as did Captain Coddling and his men afore-mentioned, the shipowner got all his insurance money. If the crew went down with the ship, the owner got no more. In the same way, if an industrious and well-meaning firebug burned half a dozen people in their beds, that fact neither added to nor took away from his gains. We turn now, however, to a class of cases in which the consummation of the transaction is absolutely and necessarily dependent upon human life. Now, this world is old enough, and we have a sufficient knowledge of its history to enable us to contemplate 
the death of countless myriads of men. The harvest of death goes on about us continually. As there is nothing more certain, so there is nothing more common than death. We contemplate death from a religious, from a statistical, from a personal, even from a humorous point of view. Yet, if there is anything in this world that is worth looking at with open eyes and a straight face, it is death; if there is anything worthy of respect it is human life. Without stopping to quarrel with those exceedingly modern gentlemen-always exceedingly modern, yet existing in every generation - who believe the whole human race and its history to be a piece of comedy, I prefer to regard the matter as a serious one. If life insurance is abused, or, at any rate, if it is abused in certain ways, it means that human life will necessarily be jeopardised; and, to my thinking, there is nothing more worthy of attention.

Nor is the danger so slight that the question is merely academic; the question is a practical one of far-reaching importance. Life insurance, whatever it may be in other countries, becomes more and more important in English-speaking communities. Not because the people in those communities happen to express their thoughts in a particular tongue, but because the speaking of English carries with it, as a matter of fact, certain great characteristics which, for want of a better name, I shall call tendencies toward individualism. The Collectivist school of the art of society will quarrel with that word, and, perhaps, with the idea expressed, in view of what they regard as the tendency of our time in certain particulars. Without arguing the matter, I venture the opinion that the influence of English-speaking communities, on the whole, stands for individual right and duty. Even with the Collectivists of our time and tongue, the appeal is not to the glory or greatness of the State, but to the happiness, if not to the right, of the individual. In countless matters, so small and so common that they are forgotten, individuals in English-speaking countries stand free, 
while in many other countries, the State is in supreme charge and control. Even in France, the freest of all non-Englishspeaking lands, every man of any actual or prospective importance knows that he is under the surveillance of the police, and that his dossier, or record, is on file, to be kept secret only so long as he does not contravene some police rule. In the vast majority of countries in which the English is not the predominant influence, a man moves about, or engages in any business, or publicly expresses opinions, only by consent of the governing power. Such countries have their newspapers and postoffices, but these are managed by the masters rather than by the servants of the people. In every English-speaking country, it is true, there are complaints of "autocracy," "Cæsarism," "bossism," and so on. But it is noticeable that those who make these complaints declare that if the tendency they observe and object to is not stopped, the country will become as Russia, or Turkey, or Spain, or some South American republic. It is the like complaint that a millionaire makes of the extravagance of his family, his wail being that he will end his days in the poorhouse; - the suggestion of what is coming marks the contrast with what is.

In no respect is this reliance upon the individual more noticeable than in the completeness with which the duty of providing for those dependent upon him is left to every man. This is a purely modern and purely English idea. In low stages of human development, the rough-and ready law of the tribe provides for the helpless, whether old or young; infanticide and the abandonment of the aged being practised. Under the clan system, and under the village community system, the place of every individual is rigidly fixed, his or her duty being prescribed and suitable subsistence provided. This is continued through the machinery of the guild in those communities that are of industrial origin. Under the feudal system, with the church as part of the system, the lord of the manor was 
supposed to care for those upon his lands, while the abbot of the monastery or some such person was the appointed host of the traveller, and the duty of hospitality on the part of every householder was made part of the law of the land. In such countries as Greece and Rome, the universal practice of slavery, or of a form of peonage which meant the same thing, provided a legal refuge for the distressed. Under other systems, such as the Jewish and the Mohammedan, the right of those who need to share with those who have is not merely a moral right, but as much a legal right as it could be made.

In the case of any or all of these, the law might be evaded or even flatly defied; but the law was there, none the less. Nothing is more marked in the history of the feudal system than the usurpation of the landlords, not only as against the people but as against the sovereign. We know how shamefully some of the clans, as for instance, in the Highlands of Scotland, were betrayed and oppressed by chiefs upon whom they had lavished love and fealty. And Jesus himself denonunced the subterfuge by which some evaded the duty of caring for the aged which duty was written upon the very Tables of the Law. When, in our own day, we see laws made of none effect by social conventiou or court decision, we can easily understand that, even though the widow, the fatherless, and the aged were not cared for, that fact alone would not prove that the law had not made as thoughtful provision for them as possible.

In English-speaking countries we have gone farther than merely to pass such a law and then disobey it-we have repealed the law itself, or, in new communities, have never passed it. I know that we have the ridiculous or pitiful or outrageous-according as you regard them-Poor Laws of Great Britain; also the pale reflections of them that we see in some of the States of the Union; also the well-meant experimental laws of some of the Australasian colonies. Yet, knowing this, 
I regard it as a historical fact that, for the first time in this cycle of civilisation, we of English-speaking communities have left the care of the dependent to voluntary action instead of to the action of the State. Under our law first, if not alone, it has been provided that to be helpless does not of itself constitute a legal claim upon society. And this notwithstanding the factassuming it to be a fact, as I believe it to be-that in our time and in English-speaking countries we have a keener sense than others of the claims of the distressed. All this means that life insurance, in some form or other, must do for us what statute law and a department of government have done, or pretended to do, for other people.

On the other hand, it is to be noted that interferences which formerly were practised to affect the free actions of individuals are no longer tolerated under the law. The right of a man to himself and to the product of his own labour is essentially a modern idea; and, taking it by and large, that idea is more completely recognised in English-speaking countries than in any others. The ruler and the ruler's tax-gatherer were their own law of property in many a country. The right of the strong to take from the weak not only his property but his liberty or his life, was modified, in many cases, by caste lines and social traditions rather than by statute laws. The interferences with trade have been constant, in most countries, and often so searching and effective as to be, for us, almost unthinkable. The United States is kept for years in a state of political turmoil over a currency problem involving a mere question of percentages; but in other times and other countries, the king, without even consulting his ministers, might degrade his coinage and issue sumptuary edicts which would convulse industry. We must contemplate these things and such as these to realise the truth of the statement of Blanqui, the great French economist, that had it not been for the smugglers and other law-breakers, trade would have been strangled and killed. 
As individuals, then, we must bear this burden of providing for those dependent upon us whom we leave behind, or for ourselves if we survive our days of earning; and we are left free to do this as best we may. The great modern invention, life insurance, furnishes us a means of accomplishing what we desire in this way with a minimum of labour and a maximum of certainty. Reading the works of some of those who have written upon this subject, one would suppose that life insurance, like Topsy, had simply "growed," the reason for its existence being inscrutable. It seems to me that life insurance, like every other invention, has necessity for its mother and the desire of men "to gratify their desires with the least exertion" for its father. How the necessity arises, I have briefly suggested. How widely it is felt can be seen in a few figures showing the great growth of the business in force. In Great Britain, insurance companies, benefit societies, trades-unions, and other voluntary organisations having for their object to provide indemnity in case of loss of income through accident, old age, or death, are in universal use. Everybody, from the baby to the grandfather, is insured in some form and for some amount. In the United States, we might reasonably expect that, the people having but lately-historically speaking-come together from widely-separated parts of the world, their insurance would not be done with co-operative concerns, but rather with business institutions. This is, in fact, the case. The greatest life-insurance companies are to be found in the United States, and the spread of this business is a distinct triumph for the organising ability of the financiers of that country. The adaptation of life insurance to the requirements of all classes of the people shows the marks of American originality and ingenuity. Life insurance now is like shoes-necessary to everybody and provided in such variety as to suit the requirements, the taste, the purse, of everybody. The rapid increase of the business in the United States in recent years is shown by the following table of insurances in force: 


$$
\begin{aligned}
& 1890 \ldots \ldots \ldots 3,547,034,907 \\
& 1891 \ldots \ldots .34,868,385,818 \\
& 1892 \ldots \ldots \ldots 4,208,975,473 \\
& 1893 \ldots \ldots .44,523,478,283 \\
& 1894 \ldots \ldots .4,657,583,046
\end{aligned}
$$

$$
\begin{aligned}
& 1895 \ldots \ldots \ldots \$ 4,818,170,945 \\
& 1896 \ldots \ldots .4,967,576,418 \\
& 1897 \ldots \ldots 5,255,725,545 \\
& \text { I898....... 5,630,053,31I } \\
& \text { I899...... 6, 265,908,078 }
\end{aligned}
$$

This does not include either what is known as "fraternal" business-that in co-operative benefit societies-or "industrial" -that in concerns that insure children or adults for weekly payments.

While it is true that there has been a tendency, of late years, on the part of the wealthy, to use life insurance as an investment-more properly speaking, as a guarantee of investmentit is also true that there has been a marked increase in the number of small policies held by poor people and paid for with money saved out of a scanty income. The duty of every man to be insured has been impressed upon practically every member of the community, so that now it is the exception-the rare exception in some localities-to find a man who does not carry either an "old line" policy, or a membership certificate in some benefit society, or both.

In all other English-speaking countries, life insurance is almost as common as in Great Britain and probably quite as common as in the United States. Nor is it intended here that the reader should believe that the system is not in use in other countries as well. Though, as stated, more particularly an institution of English-speaking peoples, it is rapidly extending throughout the world. Of late years, the life insurance agent, like the representative of other industries of our civilisation, has appeared in the Orient. Not only do English and American companies operate in such countries as China and Japan, but native companies are springing into life there-mainly under English-speaking management, it is true, but to be taken over, no doubt, in course of time, like the cotton-mills and gunfactories, by natives, and managed wholly by native officers. 
The fact that life insurance has a necessary relation to questions of life and death, and the further fact that it is the main dependence for the future of millions upon millions of people, give to this industry an importance which it would be difficult indeed to overestimate.

From what has been said, it will be seen that life insurance is liable to much the same abuses as other branches of the business, but that, in this case, abuses have much more terrible effects than in others. There is the same temptation to overinsure, and the same temptation to the beneficiary to seek to realise on the contract by bringing about the event-in this case the death of the insured-upon which the payment of the amount is contingent. There is the same temptation to misrepresentation of interest and of the facts of the case as in other insurance, leading, in some cases, to the most terrible crimes of violence and to the most complicated and wicked frauds. There is even greater temptation than in other branches of the business to refuse the payment of just claims, and, in the hope of profiting in this way, to establish fraudulent companies, the real object of which is not to afford protection to the insured, but to give the promoters or officers control of, and opportunity to steal, a vast fund. It will be necessary to devote attention to several great epidemics of crime of this kind, for which the reader is referred to subsequent chapters. It will suffice here to point out why life insurance is particularly favored by company-promoting sharpers as a mask for their intended frauds.

In the first place, life insurance is of practically universal application, for there is no adult person concerning whom it cannot be said with some show of truth that his death would be a loss to somebody. The sharper thus has the whole world about him as his field of operations. In the second place, the sharper gives absolutely nothing in return for the money paid to him, except his promise to pay. If he chooses, after a time, to pay a so-called " endowment," or otherwise, to bait his hook 
when the gudgeons come but slowly, that is merely a piece of enterprise and no more necessary to trade than a big newspaper advertisement is necessary to the trade of a grocery store. In the third place, life insurance is an Egyptian mystery to almost everybody. The number of people in the whole world who believe they understand it could easily be seated in a small theatre; and, of these, there is probably not one who would admit that the others are better than tyros or dunces. The principle is simple enough, but as soon as we advance beyond the principle, the differences of opinion begin to manifest themselves, and the further we go, the more they multiply. This mysterious and elusive nature of the business has many advantages for the sharper. It enables him, by skilful glibness, to gloze over difficulties which might otherwise be apparent to even the obtuse or the illiterate. It also causes the law of insurance in almost every country to be in such a state that there are loopholes for fraud by any scoundrel who has the ingenuity to invent a new and plausible scheme for that purpose. Again, it leaves the sharper free, even after his operations have been exposed, to argue that the non-fulfilment of his promises was due, not to intentional fraud, but to the unexpected and, perhaps, unaccountable failure of some part of the scheme to "work out." If he can do no better, he can so confuse the question as to make a clear exposition of the fraud impossible, and so leave the world little or none the better for the lesson of his failure.

As in the case of other branches of the business, we shall find that life insurance, from the beginning and throughout its course, has been attended by evils of many kinds, and has been a potent cause of demoralisation. 


\section{CHAPTER XI}

\section{LIFE INSURANCE-Continued}

Some Early Abuses-Tontines-"Little Goes"-Gambling in LivesRepressive Legislation and its Results-Alliance of Insurance and the Lottery-Essential Soundness of the System-Its Persistence and Growth.

$A^{\mathrm{S} \text { soon in history as the record of life insurance becomes at }}$ the harpies by whom it is infested and surrounded. The struggle is a noble one, and the success achieved grand and inspiring. Some account of it will indicate what we have to fear in the future, and will assist us to judge what steps should be taken to prevent a repetition of the evils of the past or a continuance of those which we know to be in existence to-day.

There are references to life insurance so far back in the past that we cannot say when the business was originated or how the earliest abuses began. But, for all practical purposes, life insurance as we have it to-day is a thing of recent times. I find the statement in a newspaper that actuarial tables have been discovered in the ruins of Pompeii, these having been used by "the ancient Italian insurance agents" to show "the expectation for life of the people with whom they did business." Undoubtedly a good many things were lost by the fall of Rome which we have been obliged since to re-discover or re-invent, and a system of life insurance based upon the expectation of life may have been one of them. Another evidence of ancient life insurance is found in a statement made by Mr. Cornelius Walford at a meeting of the Institute of Actuaries of Great 
Britain that he hoped to be able to show that property carried from Cairo to Babylon by caravan was insured, as were also the lives of the merchants. One would need the learning of a Leibnitz to cover such a field of historical knowledge as to be able to pick up, here and there, the scattered material for even a brief treatise upon the subject of life insurance among the ancients. But this is reasonably certain - that if there was, in ancient times, what might fairly be called a system of life insurance, it died with the ancients themselves, and the system we have to-day is of modern construction. By this I do not mean to say that life insurance in some form has not been continually practised, but that, though practised, it could not fairly be looked upon as a system until very modern times. Men have always built houses; but only when some devoted themselves to this work, and the knowledge gained by one was, in some form, made available for the use of others, could we be fairly said to have a system of architecture and building. In every age, no doubt, there have been men who were willing to assume another's financial risk for a consideration; but, until the risk involved began to be studied and knowledge on the subject to be accumulated, nothing like a system could be said to be established.

Darwin, in his Descent of Man, while he traces our ancestry back to a connection with some congener of the anthropoidal apes and beyond, tells us that it is not necessary or possible to say just at what stage of development the name "man" could fairly be applied. In the same way it becomes merely a question of choice at what point of development we shall say that the old method of life insurance shows the characteristics of a system. To connect this part of the argument with what has been said in the chapter of the history of life insurance generally, I would remind the reader that annuities were transactions of every day; that life insurance of a temporary kind, to insure against some special contingency, was widely used by 
merchants and others having financial interests at stake, and that ransom insurance was a thing in more or less common use for hundreds of years.

It was, at one time, the fashion to speak of Lorenzo Tonti as "the father of life insurance," and, I think, not unjustly. Tonti was a Neapolitan and a genius. Even if his scheme was not very much like life insurance as we have it to-day, it certainly deserves to be called a system; and that it may fairly be considered as related to life insurance is proven by the fact that his name lives in the very name of one form of life insurance, the "tontine." Tonti's scheme may not have been original with him. In fact, there are traces of it, we are told, in Papal finance before his time. But he gets the credit of originating it and forcing it into general notice. The plan was set forth by him in 1653 , in a proposal he made to Cardinal Mazarin, the great successor of the greater Richelieu as Minister of France. The object was to enable the French king to borrow money, and the principle involved was the use of a system of annuities as security to the lenders. At the expense of this security, but of great advantage as giving a flavor of gambling highly appreciated in those times, there was something of the lottery in it also. The lenders, or their nominees, were to be divided into ten classes, and annuities granted for each class. The classes were by ages; the first under seven years, the second from seven to fourteen, and so on up to between sixtythree and seventy. Every year, the annuity on the sum loaned by each class was to be divided among the survivors in that class, and, at the death of the longest-lived, the debt was, ipso facto, cancelled. At a time when little was known of finance, and when the gambling spirit was universal, such a scheme would, naturally, be very attractive. Mazarin, however, was too busy over his witches' cauldron of European diplomacy and domestic intrigue to actually carry the scheme into execution over the veto which the Parlement put upon it. But, when 
Louis XIV., "le Grand Monarque," ruled despotically, all opposing parties having been crushed or bought, the scheme was revived in 1689 as a means of filling the royal exchequer, which was somewhat depleted by expensive wars and an almost more expensive court.

Other sovereigns, including the newly enthroned William and Mary of Great Britain, adopted the idea, and tontines became general. They were used by private parties also, and abused, of course. The result was that not only was this system of finance abandoned, but laws were made against tontines carried on by private parties. These laws, like all other repressive enactments, were more or less set at defiance and more or less evaded. But, as time went on, this great scheme of Tonti was resolved into its constituent elements of annuity, life insurance, lottery, and public debt. The name " tontine" now signifies merely a scheme for the division of the profits upon life-insurance policies. If space permitted, I could show that, even in modern-very modern-times, we have had a great deal of hanky-panky with tontine profits by the management of big concerns, books being so manipulated as to make tontine funds pay general expenses, dividends, and so on; but this evil is a comparatively small one, nobody cares particularly about it, and it is dying out of itself through sheer compulsion of the force that makes for honesty in great financial transactions.

Tonti was not the only schemer who dealt more or less directly in chances on the duration of human life. The possibilities of the annuity method were plain to others; and, little by little, the idea of life insurance as we have it to-day was developed by the plans of these schemers. I confess that I do not know where to turn for material for anything like a consecutive history of this great movement. The general historians ignore it altogether, and those who professedly deal with this as a branch of finance or of economics either have not the knowledge or have not the skill to make a connected story. 
Some suggestion of how this subject has been neglected is given by the fact that a very careful report and subsequent letters on the subject of life probabilities as affecting annuities, written by Johan de Witt, Grand Pensionary of Holland, and an all-round great man, were absolutely lost sight of from the time the report was presented to the States-General-about I670-until I850, when it was exhumed from the State archives of Holland by Mr. Frederick Hendriks, an English actuary. There can be no doubt, however, that even during the time when the record seems most broken, the principle of life insurance was making its way forward over obstacles apparently insurmountable, and in spite of foolish friends and treacherous enemies.

We are left to judge of this not so much by any reference made by historians to the facts as by the laws passed from time to time against insurance. These laws indicate that there was a strong, and, among some classes at least, general belief that this business was evil in itself or would necessarily lead to evil consequences. We might be inclined to class laws against insurance with the still more numerous enactments against usury and say that they were based upon mere ignorance, were it not for the fact that the recitals of these statutes show that the principle of insurance was, incontestably, vastly abused. As far back as 1570, an ordinance of Philip II. of Spain forbade life insurance in the Netherlands, over which unfortunate country he ruled at that time. As this sovereign was one of the most hateful creatures who ever sat upon a throne, and as his tyranny over the Netherlands is one of the blackest pages in history, the fact of this prohibition proves little or nothing. But we find that in many other countries similar laws were passed. A statute of Genoa, dated I588,-long before Tonti was born, it will be observed-is, intended to regulate life insurance as a dangerous thing. It is evident, from the wording of this law, that even at that time life insurance had degener- 
ated into mere gambling. We shall find a similar condition of affairs in England at a later period, and, still later, more than one outbreak of the same kind in the United States. In 1598, Amsterdam, then a practically independent republic, prohibited life insurance, and also insurance upon any voyage undertaken for merely frivolous purposes-a still clearer indication that insurance was used as a mere form of gambling, bets being offered upon the life of a man or upon some voyage which was only a pretext for those wagers. In I68I, an ordinance of Louis XIV., of France, prohibited insurance upon life, but made a special exception of cases of ransom insurance in which the person ransomed was prevented by a death of violence from returning to his home. The effect of this exception was not-merely to permit the ordinary ransom contract, but to allow the insurer to indemnify the family or creditors of the ransomed man, in case, after his ransom, he should be killed while on his way home. These are only samples of the laws against life insurance passed at one time or other, by almost every state in Christendom. We shall see very soon in what characteristic, yet effective, fashion the evils of the system were dealt with in England; but, in the meantime, a word will explain why these statutes for the promotion of morality were enacted in so many countries where far greater abuses than this of insurance existed unchecked and unrebuked.

The reason was that life insurance threatened the very lives of those in high places, who were in danger enough without it. It would require a profounder knowledge of history than I possess to explain the case at all fully. But, if the reader will consider the facts, he will see that, about the fifteenth century, two great forces began to arise in Europe-trade and monarchy. In such men as Philip II. of Spain, Henry VIII. of England, and others, we have monarchs really more powerful than the greatest of their predecessors. The thrones upon which these men sat rested securely upon the ruin of the old nobility. 
The length of the monarch's arm had been increased by many inventions: printing, the better recognition of the rules of diplomacy and of war, and the improved arms which gave the head of an army irresistible power as against any disaffected party. Moreover, the danger of royal interference in private concerns and the disaster to be feared from that interference were greater than before because of the greater interests involved. Modern trade had begun, and not only were the amounts at stake increased, but the ventures, like Antonio's, were "squandered abroad," and subject to the whim or caprice of rulers here and there. The death of a king and the accession to the throne of one known to be avaricious, quarrelsome, or unfriendly to any particular kind of trade; the fall of a minister who had protected a family or class of traders; the prospect of the success in a pending war of some usurper-these and a thousand other contingencies must be thought of by the merchant; and he naturally sought protection from ruin by insuring the lives of those in the friendly shadow of whose favor, complaisance, or ignorance he carried on his business. But the step from a bona fide transaction of that kind to a fraudulent one, as can easily be understood, was short and easily taken. It was taken; and a regular business-if business it can be called-sprang up in insurances upon the lives of men in power. Thus the sovereign might find himself the object of almost fabulous wagers, many of his subjects looking anxiously for the prolongation of his life and reign, but many others deeply interested in his death. The perils of his exalted position were thus immensely increased. It is no wonder that the whole system of insurance was put under the ban of royalty in many cases.

How far these gambling insurances may have gone, and what demoralisation they may have worked in other countries, I have not the learning to show But in England they were a prominent part of the great carnival of gambling which attended 
the growth of trade. So far as I know, no English historian has dealt at all fully with this phase of his country's growth, but here and there we catch glimpses of it. The memoirs and diaries, from the time of Elizabeth, show that as trade increased so grew the wealth of those who stood in a position to reap the greatest gains, whether by high position at court, ownership of great estates near growing towns, or partnership in great trading houses. And, as the wealth accumulated in the hands of these people, their coarseness, their lack of moral restraint, their want of knowledge of the principles by which wealth was made, led them into all forms of wild speculation and gambling. Lecky, in his England in the Eighteenth Contury, gives a partial picture of the effects of this passion as it increased to a mania, and other authors have touched upon the same theme. The most lifelike picture of it that I have seen, however, is that given by John Francis, whose work, Annals of Life Insurance, has already been spoken of. In a companion work, Annals of the Stock Exchange, some account of the results of the gambling mania are given. Until the reign of George III, "Farmer George," the king whose private life was pure and wholesome, gambling was almost completely unchecked; and at length it pervaded every form of business and every class of society. Everything, from a South Sea Scheme, upon which rested the finances of the nation, to a cock-fight in a thieves' taverneverything that could be made an adjunct to a gamble was used for that purpose.

It would be unreasonable to expect to find that a system so easily manipulated for gambling purposes as life insurance was left pure in this school of vice. On the contrary, one would naturally expect to see the facilities afforded by life insurance for carrying on gambling schemes readily and generally taken advantage of. As a matter of fact, no form of gambling was so varied, so universal, so wasteful, or so demoralising as insurance. Even the lottery, that most perfect work of the devil, 
was not complete in itself, but worked its greatest ravages through a system of insurance.

The chances that men were taking in every other way caused them to turn attention to schemes which promised them indemnity for losses, thus giving them a chance of escape from complete ruin. Without attempting a close analysis of the changes of fashion in regard to insurance, or any discussion of the reasons for those changes, it may be well to give some account of the part which insurance played in the great gambling era of England. The schemes used were of endless variety; but, to facilitate the description of what went on, the subject will be divided under four heads-annuities, gambling in lives, the "little goes," and lottery insurances. It is not intended, by this division, to suggest that these different forms were clearly differentiated in the minds of the people of that time, or that they were used by any special class of people, or were introduced successively in the order given. The subject is a large one and the confusion of the records extreme. The division is for convenience merely.

As has already been shown, the idea of annuities was an old one. We find the man Audley, whose name has already appeared in a previous chapter, making a vast fortune and a great name through his shrewd plucking of wealthy ne'er-do-wells by the purchase and sale of annuities. An example of the ignorance of the people of that time of the simplest principles of finance, and, incidentally, an example of how the law favoured the cunning knave as against the unthinking signer of a promise to pay, is found in an incident quoted by Francis in his Annals of Life Insurance. Audley, having bought for $£ 40$ a debt of an insolvent tradesman of the nominal amount of $£ 200$, refused to release the debtor for less than the face of the liability. But, after persuasion, he agreed, as if " in merry sport," as Shylock puts it, to compromise, on the debtor agreeing to pay, on demand, one penny and the same progressively 
doubled for twenty months thereafter, under a penalty of $£ 500$. Waiting for years, until his debtor had re-established himself in business and grown wealthy, Audley made his first demand. It was paid, and so were others; but when the merchant found the amount rapidly increasing, he made the calculation and was shocked to find that it would cost him $£ 4000$ to discharge the debt in the fashion prescribed. He paid the forfeit, and so Audley received $£ 500$ for what had cost him less than one-tenth that amount. The ignorance on the subject must have been more than ignorance-it was the black darkness of mind which attends the belief that knowledge is impossible. When the first annuities under William III. were sold, the same amount was paid, regardless of the age of the annuitant. A youth of twenty received neither more nor less than the man of seventy, although it would seem a perfectly obvious thought that the total cost of paying an annuity to one must be vastly different from that of paying it to the other.

In the reign of Charles II., " the Merry Monarch," another Audley, one Lopez, a Jew, accumulated immense wealth by dealing in annuities; and Francis hints that the death of some of those to whom this usurer had to pay annuities was hastened by his occult knowledge of poisoning, then one of the most carefully studied arts in Italy. However, Francis is usually more interesting than explicit, and it is not necessary to burden the memory of Lopez or the reputation of life insurance with crimes which are so far from being proven.

The use of annuities, tontine and others, by the Government, gave an impetus to this form of business, such an impetus that it soon degenerated into mere gambling. Bubble companies sprang up by the score. They promised annuities for long terms or short terms, for the continuance of married life, or for the combined lives of mother and children-anything that would attract public attention and bring in money. The failure of hundreds of them was not enough to warn the dupes in city 
and country; and as, in our time, gold bricks are sold every day to avaricious but trusting young men from the country, so, at that time, the promise of an annuity, no matter by whom made, seemed enough to win from the poorest the little store they had toiled for or stolen. Francis attributes the final overthrow of these schemes to the more accurate knowledge on the part of the learned concerning the probable duration of human life, and the spread of that knowledge among the people. This seems quite reasonable. The effect of increasing knowledge on this subject would be, in the first place, to convince those companies that sought to do an honest business that they could not carry out all the promises which their ignorance had led them to make. The withdrawal of honest concerns from the business would deprive these wild promises of whatever slight basis of soundness they may have had, and people would naturally grow tired of buying tickets in a lottery whose prizes were all blanks, as Sir Boyle Roach would have expressed it. Moreover, it is to be remembered that laws for the restriction of gambling were being enacted, and a body of public sentiment inimical to the practice was forming. These things would have their effect on every side. Gambling is like a fire-check it or suppress it in one place, and you make it easier to suppress it altogether.

As to gambling in lives, - that is, nominally insuring the life of one person for the benefit of another, the transaction being, in fact, a mere wager upon the life of the subject of the so-called insurance,-this evil reached greater and greater proportions from the time of the Revolution of 1688 , according as wealth increased and the dangers to British trade from foreign wars and domestic intrigues grew greater, and as the gambling fever increased in intensity. William's own life was insured, bona $f i d e$, for vast sums, for upon it depended countless trade ventures. Not only his life, but also his success in this or that negotiation or this or that battle was insured for the protection 
of merchants whose enterprises depended upon such contingencies. And, of course, gambling quickly followed-in fact, attended shadow-wise-these legitimate transactions. The distinction between business and gambling is not overclear even in our own day, but we do recognise a difference between the extreme of one and the extreme of the other. Judging by their actions, this idea seems to have been beyond the mental grasp of many English men of business in the seventeenth and eighteenth centuries. Men of reputation were ready to take either side of any speculation regardless of the effect of that speculation upon society. Lloyd's and other centres of business were places of wagering as well as of what we should now call legitimate business, and the reform of Lloyd's alone in this respect was a work concerning which a chapter or two could be written. While the gambling spirit possessed such places, there was nothing too absurd or too wicked for the opening of policies at some well-known centre. It will be remembered that the elaborate deceit which went by the name of diplomacy produced that most strange and interesting character, Éon de Beaumont, commonly known as Chevalier d'Éon, who, disguised as a woman, went as an emissary of the French court to Russia. So successful was he in this histrionism that there were ever after doubts as to the sex of this extraordinary individual. While he was in England, this question was debated by many, with the natural result that policies were opened on the chance, and thousands upon thousands of pounds were wagered on either side. So much was at risk, in fact, that the decision was anticipated with the most eager anxiety by the men who had staked the money, and it was stated that the Chevalier himself was offered as much as $€ 30$, o0o to settle the wagers. Francis tells us that d'Éon, who was under bonds to the French king to continue the mystery, played a rather neat trick upon the gamblers. He agreed that at a certain time and place he would give convincing proof of the sex to which he 
belonged. At the time appointed, as many as could crowd into the coffee-house room were present, hoping at last to win their bets. The Chevalier arose and declared himself a man, offering, if any present doubted it, to prove his statement in single combat. The beefy merchants who had money at risk were not ready to take the chance of being carved, even by one whom they believed to be of the weaker sex.

Pages could be filled with a relation of anecdotes illustrating the wildness of the gambling carried on in the very marts of trade. Let one more suffice. In 1765 , a speculator brought about eight hundred Germans to England under specious promises of easily accumulated wealth. Whatever his scheme was, it did not succeed, and he abandoned the unfortunates whom he had enticed from their homes. They were campedif it can be called "camping," seeing that they were without shelter -in an open field, and were absolutely destitute. Starvation and the diseases that attend starvation soon came to the relief of some of them. Day by day, the death-rate amongst them increased. The poor unfortunates did what they could to help themselves, and a few charitable people who knew of their condition contributed to their support. But the insurancemongers, instead of helping to ward off starvation from these exiles, actually opened policies on the chances of the death-rate increasing. Fortunately for England's good name, and for the poor Germans as well, this was the one thing needed to loosen the purse-strings of the rich. When the fact of this ghoulish traffic being carried on became known, means were found to provide the outcasts with food and shelter.

These incidents help us to understand the coarseness of fibre which was characteristic of the people of that time. Another manifestation of the same quality was in the bribery of public officers. Under Charles II. bribery was universal; under William III. it remained unchanged, except that it was systematised. And, until a much later day, there was very little 
improvement. This system worked in well with the gambling insurances, particularly as the distribution of news was slow and uncertain. Ministers and others were able to win money by betting on the winning side of events after the receipt of despatches showing exactly what had happened. Thus, the Spanish minister to England during the Seven Years' War insured against the fall of Minorca to the extent of $£ 30$, ooo after the despatches announcing Byng's withdrawal and Blakeney's surrender were in his hands. Even though cases cannot be cited of murder of those whose lives were insured for the benefit of those who had no insurable interest in them, it can easily be seen that Francis is justified in hinting, as he does, that such results were almost sure to follow. Certainly it could easily be shown that death was hastened in many cases by the knowledge on the part of some distinguished invalid that the premiums on his life had taken a sharp upward turn at Lloyd's, indicating a belief in the City that he was near the grave. Walpole, whose life, whose chances of power, whose success in different undertakings, were favourite subjects for this kind of speculation, bitterly and picturesquely denounced the speculators as "death brokers."

At length repressive legislation was imperatively demanded by public opinion. But, instead of following the Continental plan and prohibiting insurance altogether, the British Parliament passed a most wise and just law. This was the statute of I4 George III. (1774) already referred to. The effect of this enactment, so far as concerns the point to which we are now referring, was to provide that no life-insurance contract should be valid unless the beneficiary of the policy had a bona fide financial interest in the life of the person insured. This law seems to have been effective on the whole-remarkably effective considering how persistent and extensive have been the infractions of other laws apparently equally strong.

Turning now to the "little goes," we find them referred to 
in every work that deals at all extensively with the history of life insurance in England. Just what they were, the authors themselves do not appear to know; or, if they do know, they seem to assume an equal knowledge on the part of their readers. But this is characteristic of English writers generally. A Mill or a Malthus will discourse about the "rates" or about the rights of tenants as though everybody who read them lived on an English farm or paid for the support of the English poor. The "little goes" seem to have been co-operative clubs made up for temporary purposes, and combining a maximum of lottery with a minimum of insurance. Just what relation they bore to the "insurances" in connection with the State lotteries, which are referred to in the next paragraph, does not clearly appear from any of the authorities within my reach. According to Francis, the "little goes" were first set up, or opened, or what ever the word should be, in I708. The scheme first proposed was a club the members of which paid five shillings each per fortnight to insure $£ 200$ on their lives. This was a very high premium, and would not be likely to attract many. But the idea was taken up by other speculators, and the terms were made to suit the purses of those who might be expected to seek membership in such concerns. Other events than death were insured against. Thus, marriage portions were provided; capital sums were guaranteed in case of the birth of a child; the expense of a funeral was undertaken, and so on. While there were some of these concerns honest enough in conception and management, the vast majority of them were mere schemes for collecting money for the benefit of the promoters. Of course, these promoters were obliged to make some payments, but these were mere bait for the gudgeons. A man might see very clearly that the institution in which he thought of enrolling himself could never redeem all its promises. But, on the other hand, he could not deny the fact that friends of his own had put in little and taken out much. It was the old story, 
"It will last my time, and why not I win as well as another?" One of the anecdotes of this phase of gambling is about two young people who joined a marriage-portion club, married each other after the payment of their first fee, and collected a double marriage portion. This was distinctly an invasion of the privileges of the promoters, and, in subsequent policies, a repetition of this trick was provided against. With London swarming with these bubble-mongers, one can fancy the demoralisation. The people robbed were not the wealthy, but the poor, and not only their money but their hopes went with the ruin of the insurance office.

This feature it was which made the fourth in our list of forms of insurance gambling - lottery insurance - the worst of all. Apparently a scheme arose of insuring the holders of lottery tickets against loss in any event, on condition of their paying either a certain fixed sum or a percentage of their prizes, if any. From this to insuring the man who had no interest in the lottery was but the short and easy step which had been taken in other forms of insurance. The idea soon developed into a private gambling business based upon the chances of the lottery, and the fees were made small enough to allow everybody to take part in the game. While other forms of gambling corrupted, as it were, the skin or the flesh of England, this ate into the very bones. "Insurances," as they were called, became to the lottery what the bucket-shop is to industrial finance. And, when the bucket-shop is so bad an institution, though based upon one that is sound and good, we can faintly imagine what this excrescence upon the lottery-a corruption of a corruption-became in the course of a short time. Other forms of gambling were confined mainly to the City; but the "insurances" had agents in every hamlet. Broken-down dealers, speculators, and gamblers eagerly grasped at the chance to prolong their lives and be still in sight of Fortune's wheel by undertaking to bring in new victims. These 
canvassers were furnished with red morocco pocket-books to carry the papers necessary in their trade, and so gained the name " morocco men." Through their influence, combined with the attractions of the scheme itself, all classes engaged in this form of gambling. The mania grew to almost incredible fierceness. Servants robbed their masters, husbands took the wages that should have been used to support their wives and families, even mothers pawned their children's clothes-everything that could be turned into money was heaped upon the counter of the "insurances" in the hope of gain. Thousands were ruined; some starved to death, while others anticipated such a fate by suicide; many were transported or even hanged for the crimes they had committed in order to get money to keep their places in this fascinating and demoralising game. Parliament and the Goverment tried in vain to stop the craze without abandoning the nation's interest in the prime cause of it, the lottery. Severe measures were attempted, but evasion was easy. And when the Government resorted to force it was met with force. The employees of the insurance offices were a formidable body, not only because of their numbers, but because of their daredevil character, and, more than all, because public sentiment was, in great degree, on their side. According to Francis, the insurance offices were able to muster an army of about ten thousand men, "morocco men," mainly, and reckless fighters. He says also that "blood was freely shed" in defence of the gambling game, but he lays more stress upon the bribery, cajolery, and browbeating of the constables and other officers to which the insurance offices freely resorted. After several half-hearted measures directed against the "little goes" and the lottery insurances, the British Parliament finally, in I826, declared against all lotteries. The gambling quickly died, not so much because of the prohibitive features of the legislation as through the fact that the basis of the whole affair, the government lottery, was removed. 
Had there been nothing of life insurance but the corruptions here briefly and imperfectly pictured, the system would have died very quickly, even by causing the death of the nation it fed upon, if other course had been impossible. But underneath all these parasites and excrescences there was something sound and strong, something necessary to the social life of modern people, and affected favourably as well as unfavourably by the development of society.

Nothing seems more wonderful to the student of man's progress than the way in which every invention helps so many others. We say, for instance, that a bicycle tire is made of "rubber." The very name indicates the origin of the invention. The material was first brought to the notice of those who gave it the name which has survived, as a means of erasing or rubbing out pencil-marks. The man who first imported it into England and sold it to artists for the use stated, had no idea that he was helping to invent an air-cushion for a twowheeled go-cart to benefit and delight millions of people then unborn. Nor did he know that he was helping to make a composition which would be the one thing needed to make ocean telegraphy a commercial success.

After this manner, life insurance is a combination of inventions which were not designed originally as part of such a system. A game of cards being interrupted, and the players unable to agree upon a basis for the division of the stakes, one of the players submitted the question to the great Pascal, the most eminent mathematician then living. This led to the working-out of the first problem involving the laws of chance. The knowledge of those laws that has been gained since that time has been used in many ways. To read of the great theory of probabilities even in an encyclopedia, still more to read of it in books devoted to the subject, is to see that this doctrine is like a great system of braces in the structure of our industrial life-concealed and seldom thought of, yet necessary to the 
very existence of the fabric. And in no branch of business has it been quite so directly important as in life insurance. It is true that, for many years, these curious calculations of the probability of a given event coming to pass were used mainly by gamblers to direct them in the laying of their wagers. For this reason, the whole system was condemned by good but short-sighted people. In spite of its low origin, however, the doctrine of probabilities lived and throve. Not all the people of the time with which this chapter mainly deals were rakes or moneygrubbers. Among them were many men to whom the excitement of war or the gaming-table, the ambitions of courtiers or the blandishments of women, were not all of life-men who delighted in learning for its own sake, and who, under the gentle but constant stimulus of the spirit of liberty, ransacked nature, literature, society, and the human soul in their search for that wherewith to gratify their noble curiosity. To such men the question of dividing the stakes in a gambling game was not one to be settled with the small sword for the mere money involved, but one to be argued in ponderous tomes or in great letters addressed to their learned friends, in which all the learning of past times and all the originality and inventiveness of their own were brought to bear upon one side or the other.

The theory of probabilities had to be applied in a particular direction to be available for the uses of life insurance, that is, in the calculation of the average duration of life among certain classes of people in certain conditions. But for very many years, so far as England was concerned, the facts were not available for these practical calculations. Nobody knew how many people were born or how many died in any place or of any class within a given time. In the countries of Continental Europe, the representatives of the church, who were, in most of these countries, representatives of the State also, kept close count of the people. But these people also directed the provision that was made for the dependent class, and they led the 
movement for the suppression of life insurance where it was abused-and it was abused everywhere. Thus, where the statistical information was available, it was of no use in helping on the work of bringing life insurance to perfection; and in England, where the information was desired, nobody possessed it. Not that this study was merely neglected in England: the people prided themselves upon this form of ignorance and clung to it as part of their religion. It seems almost inconceivable that there ever was a time-at any rate, since the invention of printing-when the population of London was not known. Yet the fact is, that this information was not available for popular use until the beginning of the nineteenth century, the first official census being then taken. Earlier proposals for taking a census were voted down, and those who made them were regarded as enemies of the country or as wretches who would presumptuously and impiously seek out facts which were in the keeping of God alone.

Even in the absence of census figures, however, there were means of approximately calculating the death-rate in any given part of the country. This figure ascertained for some small place, and a count made of the people in the place, it was possible to make a fairly good guess at the population even of London itself. The number of deaths could be learned from the bills of mortality. These bills of 'mortality were weekly returns of the number of deaths that had taken place. They were begun in 1592 and were continued for some years. Recommenced in 1603 , they have been issued weekly ever since. The object of this compilation was to show the people exactly what the effect of their dreaded visitor, the Plague, really was. The wise men of England saw that the reports of the ravages of the Plague were exaggerated and that they excited fears which predisposed people to attack. To give the people courage, the authorities issued these figures. As the age of the deceased was given in each case, the bills of mortality, in time, afforded 
a basis from which might be calculated the average number who died in any given period of life. A genius named John Graunt, a tradesman, collected the facts and, in 1664, published some strange deductions in a work called Natural and Political Observations on the Bills of Mortality. One object seems to have been to ascertain, as nearly as possible, what the population of London actually was. He reached the conclusion that there were in London 384,000 souls. As Londoners had boasted of their city as containing millions, - the increase within a quarter of a century had been given by some "authorities" as two millions-Graunt earned little popularity by this part of his calculations. Nevertheless, the leaders of scientific and political thought saw the value of the work, and the result was not only a large sale in England, but translation into several Continental languages. This work is regarded by some writers as the initiating cause of the system of vital statistics now universal in civilised countries, as well as the first of that great library of books which have been written in modern times on the subject of political arithmetic. It is satisfactory to read, as we do in Francis, that Charles II. recommended the Royal Society for the Advancement of Science, which, to his everlasting credit, he had founded, " to elect him [Graunt] one of their members, charging the Fellows 'that if they found any more such tradesmen, they should admit them all.' " Graunt had no more desire than had Pascal to deal with life insurance, yet his speculations, as well as those of other philosophers in the same line, were seized upon by the brokers and insurers who saw fortunes wagered every day upon the chances of life. And, as the dross was sifted out of the system of life insurance, and as the proportion of the valuable element in it grew greater, the investigations and calculations of practical men helped on the good work.

Another class who assisted to strengthen the foundations of life insurance were writers on the subject of interest. The fact 
that some people must borrow, and the further fact that forehanded people would not save for others unless they could gain some advantage, - some "reward of abstinence," as certain economists call it, - made the laws against usury of none effect, except as they kept down and hindered trade. As these laws failed of the effect intended, interest as an acknowledged feature of trade became more open and common, until, in our day, it is accepted as a matter of course, which not only we do not question, but which we find it difficult to believe that anybody ever could find good reason for questioning.

These three things - the theory of probabilities, vital statistics, and calculations of interest-brought together and worked into a simple, flexible, convenient system, are practically the whole of life insurance as we have it to-day.

The early abuses of life insurance, if we considered only the surface of things, would cause us to condemn the thing utterly. On looking deeper, we see in it a principle necessary to our modern civilisation; and, in the great cinematograph of history, we see philosophers, discoverers, and inventors by the score working, consciously or unconsciously, to drag it from the filth into which it was early cast, and to perfect it for the use of the people of our generation and others. Since those early days, life insurance has been abused in many and varied ways; it has given rise to its own special systems of wrongdoing; it has corrupted men and demoralised communities; it has turned back again and again to its early associations, as though tired of honest work. Life insurance is one of the most glorious achievements of our time. But it is by no means perfect; it can by no means be trusted to itself. There are dangers in it for us and for our children; and only by constant vigilance can those dangers be warded off or avoided. What those dangers are it is the purpose of the next chapter, and some succeeding ones, to show. 


\section{CHAPTER XII}

\section{LIFE INSURANCE-Continued}

Murders for Insurance Money-One of the Dangers of Modern SocietyThe Maybrick Case and Reasons for not Instancing it-The Strange Case of Thomas Griffiths Wainewright-His Elaborate and Horrible Crimes-The Insurance Companies to Blame for his Career.

$\mathrm{N}$ this and the next chapter are given the facts concerning some of the great crimes to which life insurance has given rise. The horror we naturally feel at such crimes will be allowed by some people to prejudice them against the whole lifeinsurance system. This is unfortunate. But we cannot refuse to record the facts of a railway disaster because there are some people who persist in learning from such facts that it is unwise to travel by rail; neither can we shut our eyes to the evils that life insurance promotes for fear of misleading those who have not the justice to give weight to the facts on the other side of the case.

Among the many forms of crime and wrong to which life insurance gives rise, the most horrible is that of murder for the money involved. In all other cases dealt with in this little work, I have deliberately refrained from pressing forward the element of " human interest," as the popular novelists have it. Where instances are given, they are chosen for their fitness as illustrating the general proposition under consideration. As between two instances equally useful in this way, that one has been selected which least excites feelings that are likely to interrupt a calm consideration of the question, and even these cases have been pictured in the quietest colours. But, in this 
part of the argument, I impose upon myself no such restraint. I choose cases that are most likely to attract popular attention, and I allow the facts, fairly stated, to give such impression as they may. The reason for the change in method seems to me sound. In other cases dealt with, we have before us evils which, for one reason or another, do not matter so much. The sending of rotten ships to sea, for instance, does not exist to the same extent as in former years, and the evil is one which is known and partly understood, and for which a sort of remedy has been found-a remedy that can be applied whenever the offence becomes "rank" and "smells to heaven." The burning of buildings and goods for insurance money is bad enough; but it is not the worst, and, the case being comparatively simple, the people can find a means of relief if they think it worth while to do so. The making of bogus insurance companies, and the working of gambling schemes of insurance, form an ulcer upon the body politic; but it is unimportant except for what it indicates, and it can be met with general treatment. The slaughter of children for insurance money, I hope and believe, is practically a thing of the past-a thing to be remembered not for the horror it arouses but for the lesson it teaches. And so with all other matters dealt with between these covers, except this one.

Here we find ourselves face to face with a question of the most vital importance-vital in the narrowest sense, for it is a question of life or death for many, and may become the same for society. I have attempted to show that life insurance is the machinery set up in modern times and in our society to do a work done in other societies and in former ages by social organisations forming part of the Church or the State or both. The need of the advantages offered is universal, for orphanhood, widowhood, old age, and loss of fortune are exigencies which face all classes, and against which all must be provided. The more the institution spreads, the more rapidly, in proportion, 
spreads the danger arising from any evil in the system; just as the evil of a bad army system increases in greater proportion as the army is increased. A flaw in our system of life insurance endangering the life of one, endangers for the same reason and in the same way, the lives of thousands. It will not do to say that if humanity were improved the system would be all right. As well tell a man that his clothes are of proper shape, yet they do not fit, the reason being that his figure is bad. Clothes should be made to fit him who is to wear them; and life insurance should be adapted to the society for which it is designed.

When an institution bcomes an incentive to crime, it must be changed in such a way as to remove that element. Here, as in chapters before this and in chapters to come, we meet the statistician and averager, with his tables of figures, every item worked out to several places of decimals. This irrepressible party will show that life insurance does a great deal of good, and that, on the other hand, it does very little harm. He will arrange you, on one side, the whole human race, or, at least, the whole insurable population of the country, and, on the other side, the known victims of life-insurance murders, and will utterly confound your imagination with the smallness of the proportion between them. I state with the utmost confidence that there has never been a discussion concerning the evil effects of any branch of insurance but the averager has appeared with his futile figures for foolish folks. If a doctor were charged with poisoning two of his patients, the averager might equally well enter the witness-box to prove that this same doctor had left millions upon millions of people uninjured, that he had benefited thousands, that he had saved the lives of hundreds, - and ask the judge and jury to decide the case by percentages. Admit all that is to be said in favour of a philanthropic physician, but condemn the murderer. The question before us is not whether life insurance saves lives as well as 
takes them; the question is, first, whether people are murdered for insurance money, and, second, if people are so murdered, whether the system can be so changed as to retain its good features while eliminating this bad one.

The murder of people for insurance money is, in many ways, the most insidious and most terrible form of crime. It is a commonplace of English humour that people await with chastened fortitude which some might mistake for cheery anticipation, the demise of rich relatives from whom they have "expectations." As Henry S. Leigh, "punster in chief to the Savage Club," as he has been called, puts it:

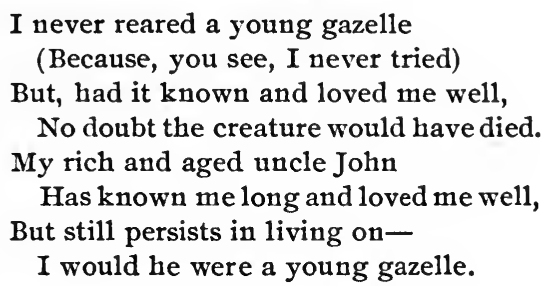

The records of crime teem with attempts, successful or otherwise, upon the lives of rich people by their prospective heirs. To multiply the people who have "expectations," other things equal, is to multiply such crimes. But the effect of insurance is far worse than the mere multiplication of those who have "expectations" from the death of others. The fact that a man stands to gain by the death of a relative does not make him a criminal either in thought or in act; nor, should he have criminal tendencies, does it give him opportunity as well as temptation to commit crime. Insurance, however, makes it possible for any grasping and unscrupulous person to profit by the death of another, and-within limits--to choose that person against whose life he can practise with the least difficulty and the least danger. Thus, the temptation is placed, not before a man here and there through his having the fortune, good 
or bad, of having rich relatives; but before everybody, and in the form that is most alluring.

Lack of opportunity is often the only thing that keeps a man from crime. Insurance multiplies indefinitely the opportunities for the blackest and vilest crime-the murder of a trusting friend for the money to be won thereby, the crime of Judas. If this is a necessary result of life insurance, my own opinion is that the cost is too great for the good that society gets out of it. But it is not a necessary result of life insurance;-we can get the good without the evil, if we will. This work will have been written in vain if it does not teach the reader that every phase of society has its own danger to fear from insurance, and that, as society changes and grows, we should alter our methods of insurance to suit our circumstances. Society is like a town in which care has been taken to build in such fashion that there shall be a minimum of danger from fire. If, in opening new streets, or rebuilding old ones, we rely upon existing precautions, we place not merely the new structures, but the whole town, in danger. The object of collecting here facts concerning some outbreaks of evil caused by insurance is not merely to retail known facts, or to awaken regrets for what is done, or to justify us in condemning the faults and failures of others, but to show that insurance has its special form of abuse for every form of society, and to convince the people of to-day that we must be on our guard, as others should have been on their guard in times gone by.

One need expect but little thanks for pointing out a fault or a danger in existing society. Reading history, we can easily see what should have been done to ward off some threatened evil of former times, but we do not realise how necessary it is in our own day to take precautions against disasters that threaten our own society. Like sheep in a pen, we see others led out to slaughter, but we complacently feel that life and all its joys are to be our portion. Yet, I venture to say, insurance 
will perfect a system of crime for our day, as it has done in times past, unless we are constantly on the alert to make safeguards against it. From such consideration as I have been able to give the subject, I venture the opinion that life insurance is the centre of danger for us. In this I may be wholly wrong; but, having made the statement, I proceed to give reasons in support of it.

In the old days of life insurance, even after joint-stock companies had been formed to carry on the business, it was the custom for every applicant for insurance to appear before the board of directors and there undergo examination. It is true that a board composed of brokers, merchants, and capitalists would hardly be likely to possess the knowledge necessary to enable them to judge, in scientific fashion, of the value of any " life" offered to them. But they could judge of it in business fashion, and that had its advantages. If they could not estimate mathematically the applicant's " expectation of life," they could learn with admirable clearness his reasons for desiring to be insured; and, if the risk was offered by one in the clutches of money-lenders or otherwise under the control of dangerous people, they could either decline the application or make the rate so high that the applicant himself would be unwilling to complete the deal. The knowledge thus gained, and the personal relations thus established with applicants, enabled those whose money was at stake to follow more closely and intelligently such risks as were accepted. That this was not an effective precaution in all cases proves nothing. It must have been effective in some cases, and might have been in all, if properly used.

As business increased and cases grew more divergent, this plan of having the applicant appear before the board of directors was found a clumsy and unworkable one. The study of mortality tables, pathological symptoms, and the effects of environment became more and more important. The application 
of the law of probabilities and the close calculation of averages took the place of the "rule of thumb" methods of a simpler time. The expert examiner's report and the other documents in the case took the place of the applicant before the board of directors. Even this has been outgrown in the case of the large companies;-paid officers decide which applications are to be accepted, while the directors deal only with large questions of policy and of finance. These changes, in their turn, facilitate the centralisation of business, and so the policies issued by one company are multiplied, until a return to the old methods is unthinkable. The old method is not necessarily any better than the new; but the two are different, and to proceed as if they were the same is mere folly. The loss of personal contact between insurer and insured is the loss of a shield to society against some of the worst evils of the business. Something must be put in place of this element, or society is placed in unnecessary danger. A consideration of such cases as those that are detailed in this and the next chapter-and probably every reader will have knowledge more or less complete of others of the same kind-will show that it is not enough to make sure merely that the applicant is sound in body and mind. This may be enough for the insurance company. Even if a man commits suicide within a few days of the acceptance of his application, the company, if its rates are high enough, can pay the loss with the pleasant feeling that all such losses have been paid for. But society has a right to be free from the apprehension that insurance companies are offering special inducements to men to kill themselves or others. The companies should be required so to carry on their business that it shall not become a force undermining the very foundations of society.

Had I not been convinced that even the most sacred relations of life are weakened, even corrupted, by the constant pressure of insurance misapplied, I would not venture to hint at that to 
which I now call attention. But I appeal to the facts given elsewhere in this work to justify me in saying that, dishonouring as it may appear to our humanity, there is danger in the effect this institution exerts upon the home.

Our society hitherto has proceeded upon the theory that a man and a woman are to establish a home, with the man as breadwinner and the woman as housekeeper. Under such conditions, the woman's work follows that of the man and is dependent upon it; and, at least in this sense, the woman is dependent upon the man. While this is the relation, the woman deprived of her husband is necessarily reduced in worldly circumstances. So completely has this been the case that, in all our literature, deserving poverty is typified by the widow of the honest toiler. Even a large sum of money paid at a man's death was no such advantage to his widow as to compensate for the loss of the breadwinner. But, nowadays-not universally, as the writers for metropolitan newspapers would have us believe, but in large masses of society - woman is the wage-earner, actually or in possibility, equally with the man. There is a joke about the young lady who confessed to her lover that she would like to marry, but hated to give up her fifteen-dollar-aweek position in the store, and was advised by him to hang on to it, he being willing to give up his situation, worth only ten dollars a week. This joyous jest would lose most of its point if it lost its cold, matter-of-fact truth. The woman who, as wife and mother, keeps the house to-day, finds that widowhood is not committal to poverty, but merely change of occupation. She no longer has a house to keep, but she can take up any of a hundred lines of business and make an income equal to that she had before. If she has been a true wife-using the adjective in its broad and proper sense-the death of her husband is an irreparable loss to her; but if the match was or has become a loveless one, there is no sentimental, as there is no financial, loss.

It is not necessary to jump at once to the conclusion that the 
suggestion here offered is that the women of modern times are about to enter upon a speculative business in insurances on one side and poisoned husbands on the other. That there are such cases, nobody who knows anything of the facts will venture to deny; but that they are comparatively rare everybody who has studied the matter will be ready strongly to affirm. But, long before there could be a wide multiplication of such nauseating crimes, there would be a much wider weakening of the ties of solicitude and care which bind wives to husbands. This is only another way of saying that, of two average women, equally fitly married and equally attached to their husbands, that one will take better care of her husband's health who stands to lose all her earthly goods by his death, than will the one who stands to receive a large sum of money from a similar cause.

It may be said that this is an argument against all marriage, or against all accumulation of property by married men, seeing that the wife of any well-to-do citizen benefits, in a strictly financial sense, by becoming a widow and an heiress. But ordinary property and property in a life-insurance policy are radically different in one respect which strongly affects the case. The wife gets the benefit of her husband's landed or other property more in his life than after his death, for she has him to manage it for her, she receiving, often, the main benefit from the income. Suppose, for instance-an every-day case-a man who is well-off in having a prosperous business, with the real and personal estate suitable thereto. While he lives, the income from the business is large and steady, and the wife, by reason of this, has everything that heart can desire. He dies, and what a change! The business, lacking its head, is found to be in such a condition that nobody can carry it on, at any rate for a time, without actual loss. The property, such as it is, is handed over to the widow; but she finds that it means worse than nothing to her. Contrast this with the case in 
which the man's life is insured. The insurance, instead of being a source of revenue, during his life, is a cause of great expense. In many a household, the necessity for the payment of life-insurance premiums is the standing reason for economy. The death of the husband not merely stops this outflow, but immediately places the widow in possession of hard cash to an amount far beyond any previous realisation. Surely we deceive ourselves if we proceed upon the assumption that these two cases are alike. The danger involved where the wife's life is insured for the benefit of the husband is clearly recognised by the insurance companies themselves. The coarser nature of the average man, as compared with his wife, makes him more apt to weigh his partner's life against the insurance money than the woman would be if the cases were reversed. As this danger is recognised, it need only be mentioned in passing.

The decline in the effectiveness of the sanctions of religion is weakening the marriage tie. It is unnecessary to argue this point: if the reader does not already believe it, no words of mine or of any authority I could quote would be likely to convince him. The industrial emancipation of woman is weakening that tie in another way. The greed of gold is weakening that tie in still another way. It may be argued that other considerations, other forces, are making that tie stronger, more sacred, in the eyes of thousands and millions of our best people; -I myself could give a multitude of facts in support of such a belief. But these forces thus working in different directions do not have the effect of cancelling each other, and so leaving everybody exactly where he was before. The effect of the good forces is to improve some people, while the effect of the bad ones is to demoralise others. Gladstone may or may not have been right in saying that it was the proper function of Government to make it easy for people to do right and hard for them to do wrong; but the idea is a noble one. Certainly we have no right to put stumbling-blocks in others' way. So far 
as in our power lies, we should help on those forces which tend to make the home, and its corner-stone, marriage, all that we believe they ought to be, and should be most careful not to release a force which tends in the wrong direction. If life insurance is not only indiscriminately granted, but actually pressed upon those who are unworthy of it-we are regarding this matter from a sociological point of view, not as a mere question of "expectation of life"-we are placing, as it were, a great weight on the wrong side of the balance. That weight will have its effect in individual cases; and, as the number of these cases increases, the effect will be seen in the demoralisation of society as a whole. It is unanimously declared by those who speak as having authority in these matters that the very basis of our society is the home. A home must have its material part; but that which gives it life, that which keeps it pure, is not matter but sentiment, or, if you will, a power yet higher and holier than sentiment. To increase the material element unduly is to change the very nature of the thing itself. If we are to change the nature of the base upon which our society rests, it should be done, not as the result of the blind working of a force which, while we have called it into existence, we do not understand and have not yet shown ourselves able to guide or control, but as the result of the careful and prayerful thought of our best men and women.

I have already said that, in indicating this as the point at which insurance threatens society in our day, I may be wholly wrong. He would be a bold man who should say that he could foretell with certainty the effects of a force so pervasive, so subtle yet so powerful, as insurance. My object is not to dogmatise, but to suggest. But, seeing in how many ways this good servant has wrought evil among men when allowed to work unchecked and undirected, it is surely the part of wisdom for us to learn from the past what should be our action for the future. 
Believing that life insurance is the dangerous element in this business for our day, I summarise a few cases that will illustrate what it has done. I have not sought to multiply unpleasant details. Had that been the object, I could have filled many such volumes as this with material of that kind. Aside from the point that life insurance threatens the home as the institution upon which our society is based, there is the broader point that life-insurance money, improperly placed, stands as a constant bribe to inhumanity, and that that bribe has been taken by villains to commit the very blackest of crimes. The cases cited, if they stood alone, would mean nothing. My contention is that these are but the mountain-peaks of crime which indicate a slowly rising continent of evil.

At this point, I desire to deal with a matter to which my readers have a right to expect me to refer-the Maybrick case. This is the most widely known criminal case in connection with life insurance that stands on the records of history; and, naturally, if it does not occupy a prominent place in a work professedly dealing with that subject, some explanation is in order. The facts of that case, briefly stated, are as follows: Florence Elizabeth Maybrick, an American woman, was the wife of an Englishman, James Maybrick. They lived in comfortable circumstances, in Liverpool. Maybrick was not satisfied with his own state of health for a good many years, and was in the habit of taking doses of drugs, some of them of a poisonous nature. He died, after an illness of considerable length, on the Irth of May, I889. His wife was at his bedside during his illness, but seems to have been suspected of attempting to poison the man even before he took the dose which, admittedly, caused his death. The woman was arrested, charged with the murder of her husband. The trial took place before Sir James Fitzjames Stephen. It was shown that, not long before his last illness, James Maybrick had insured his life in an American concern for $£ 2000$; but this fact was but little dwelt 
upon as a motive for the crime, the main motive alleged being the prisoner's hope of marrying another man with whom she had fallen in love. During the trial; the judge showed strong animus against the prisoner, insomuch that he was hooted by the crowd on leaving the court. The jury brought in a verdict of "Guilty," and the prisoner was sentenced to be hanged on the 22nd of August, I889. But, by executive action, five days before the date fixed for the execution, the sentence was commuted to imprisonment for life. Three months after the trial, it became evident that the judge was not in his right mind. This fact threw a cloud upon the trial itself, and has been cited over and over again as one of the strong points in Mrs. Maybrick's favour, by those who have tried to gain her release from prison. The authorities have refused to release the prisoner. On the other hand, no second trial has been held; Mrs. Maybrick is still in an English jail. The prisoner has many influential friends, and the case has been forced into the position of a quasi-international question, and more or less patriotic feeling has been aroused in connection with it. For these reasons, the name of the central character in this drama of real life has become well known wherever the English language is spoken.

The case is a good one for illustration of the argument here presented, except for one thing. If the woman had been clearly guilty of the murder, as alleged, the British law being what it is, she should have suffered the death penalty. Her sex would have made such a punishment most repugnant to public feeling; but her sex made her crime-if she were guilty -most heinous. The fact that she is still alive may prove a failure in the system of administering the law or too great tenderness on the part of those charged with its administration; or it may prove that there are still doubts of the woman's guilt. On these points there are strong opinions, and it would be easy to find good ground for taking either side. I confess, however, 
that I have not studied the case with that view, and have no opinion concerning it. Enough for me to know that the case is not complete at every point-that the argument concerning it, rightly or wrongly, is still in progress. For the purposes of this work, I have assumed that Mrs. Maybrick is innocent and that she has been unjustly condemned.

If any of my readers who happen to be at all familiar with the criminal records of our time will pass in review the most notorious cases, he will see that a strikingly large proportion of the worst of them have the greed of insurance money as their mainspring. This is true not of this generation alone: similar cases were known to our fathers. I close this chapter with a brief account of one of the most interesting and remarkable of them-the "Janus Weathercock" case.

Among the many circles into which literary society in London has, at different times, been divided, few have been dwelt upon with greater delight by lovers of books and their authors than that of which Charles Lamb was a leader. Lamb's friends included a number of his fellow-contributors to the London Magazine, in which, about 1820 , appeared that delightful series of essays which, as the Essays of Elia, are to be found on the shelves of every library to-day. One of the members of this circle was a man who wrote light and flippant sketches and gossip over various pen-names, the best-known being "Janus Weathercock." The real name of this writer was Thomas Griffiths Wainewright. He was a man of good family, a representative, in fact, of the idle class run to seed. In early life he was a soldier, but soon showed his love for a life of graceful ease, with some aspiration for that fame which he felt that his literary and artistic talents could easily win for him. At about twenty-five years of age he entered upon a literary career, those productions which brought him under the notice of Lamb being among his earliest. He is regarded by some critics as the founder of the "dandy school" of writers whose "florid 
euphemisims," as found in Disraeli's Vivian Grey, were so unmercifully condemned by Hazlitt. Wainewright wrote of art and manners, in the tone of a coxcomb, reflecting as in a mirror his own character. He was a devotee of fashion, and, in dress and manners sought to impress all with his conscious superiority. He afterwards turned to painting, of which he had chattered with graceful gaiety in the pages of the London, and completed several pictures which increased his fame. His style, both in literature and in painting, was meretricious, however, and his works, after rippling the surface of public attention, sank into oblivion. Desiring only the gratification of his tastes, including his love of praise, Wainewright had none of those practical virtues of well-considered self-seeking which take the place of higher qualities in keeping so many in the strait and narrow path of honesty. He spent money lavishly when he had it, and went in debt gaily when money was scarce.

Marrying in I82I, he set $1 \mathrm{p}$ an establishment which gratified his love of display and enabled him to extend social courtesies to some of the great men of the time: Macready, the tragedian; Wilkie, the painter; Lamb, the writer, and many others. His house was filled with exotic plants, china, pictures, and other beautiful and expensive things-it was, in fact, a forerunner of the so-called "dens" of the æsthetic school of a later time. His cellar contained the finest wines, and his taste in horse-flesh was too exacting to be gratified by anything but the very best. His income was about $£ 200$ a year, the principal from which it was derived having been placed in trust by his grandfather, whose beneficiary he was. Of course, this income met but a small portion of Wainewright's expenses. He picked up money where he could, one of his schemes being to impose upon rich but ignorant people who consulted him in their purchases of pictures and other works of art. Even this form of polite swindling soon proved too slow. He took the step which separates wrong-doing from felony in 1826 , when 
he forged an order by which he acquired control of a portion of the principal of his fortune. Of course, he was in almost desperate straits before he made this move. The money he thus acquired at the risk of his life-for forgery was a capital offence in the England of that time-served but to pay some long-outstanding bills, and in a short time the unfortunate spendthrift was as badly off as ever. An uncle, a Mr. Griffiths, moved to pity by the man's miserable position, invited Wainewright and his wife to make their home with him, he having a handsome residence in a good quarter of London. The invitation was accepted. The act proved a warning in the end to all future benefactors. Griffiths died "suddenly" within a year, and Wainewright inherited his property. This was not enough, however, to satisfy Wainewright's creditors and also Wainewright's genteel tastes. The fact that an uncle had died and left him rich seems to have suggested to him a use for his other relatives. He invited his mother-in-law and her two unmarried daughters-half-sisters of Wainewright's wife-to live with him in his London house. This increase in his household was actually made. Soon after-this was in $1830-$ Wainewright insured the life of one sister-in-law, Helen Frances Phœbe Abercrombie, " a buxom, handsome girl of twenty," as she has been described, in two insurance offices for a total of $£_{3000}$. $\mathrm{He}$ desired to place a larger amount, but the girl's mother objected. In a short time the mother also died "suddenly," leaving Wainewright free to carry out his scheme. He then placed no less than $£$ r 8,000 on the life of Miss Abercrombie, and, soon afterwards, poisoned her. But, when he put in his claim, the companies resisted, on the double ground that there had been misrepresentation of fact in the application for insurance, and that Wainewright had no insurable interest under the law in the girl's life. Wainewright blustered, but did not enter action to compel payment. In fact, he was soon forced to drop the matter, for he saw that there was danger ahead. He fled 
to France, where he lived for several years. In that country, also, he came under suspicion. He insured the life of a friend, and the friend died soon afterward. On arresting Wainewright, the police found strychnine in his possession and made a case against him in which his guilt was morally proven. But legal proof was lacking, and Wainewright escaped punishment.

In 1835 , driven to his wits' end by the state of his finances, he actually began action against the insurance companies for the sums that had been placed on his sister-in-law's life five years before. In connection with this suit or some other matter, he foolhardily ventured to cross to London. The police learned of his presence and arrested him. A conference of the peace authorities and private parties interested being held, it was decided not to prosecute the man on the poisoning charges, but to proceed against him for forgery, the evidence being stronger and more easily obtained, and the penalty being nominally as great. Even while under arrest, Wainewright kept the coxcombical swagger which had been his greatest peculiarity in the days of his worldly success. He wrote with pride that the common criminals of Newgate knew him for a gentleman and respected him because the crimes of which he was accused were gigantic. His condemnation and sentence to penal servitude for life still left him spirit to write and speak to friends in the same strain. But his lack of moral balance led him into a fearful mistake when it caused him to send to the authorities a confession, the exact nature of which has never been made public. The result of it was to cause instructions to be issued to put the sentence of transportation, which had not been executed, into immediate effect. At last the realisation of his terrible position overbore him. The jaunty braggart disappeared, and the hunted, caged, and condemned criminal alone was seen. This notable malefactor died in exile in $185^{2}$.

Wainewright's case was remarkable in itself, and the man became most notorious. But the notoriety of his acts became 
immensely greater because literary people, the class among whom he was best known, found in him and his career a great store of "material." De Quincey has an account of Wainewright in his essays, and many of less note than this great stylist have used him as a text for sketches and moral essays. The novelists have also made use of the theme. Lord Lytton is said to have modelled one of his most hateful charactersVarney-in one of his most detestable novels-Lucretia-after this man. So horrible were the details of the story that an outcry of indignant protest was raised by the public, and, in his second edition, the novelist made a semi-apology and changed the ending of the tale. Charles Dickens is said to have taken the suggestion for his story, Hunted Down, from Wainewright's career.

There are two points in the case of Wainewright that are worthy the reader's special attention. In the first place, the insurance companies, in placing $£ \mathrm{I} 8,000$ upon the life of a young woman in favour of a notorious spendthrift, and one who, though her brother-in-law, could not show any possible interest-insurable interest-in her life, entered upon a mere gambling transaction, - a transaction that was illegal in form, and that might be suspected as criminal in intent. They were, prima facie, aiders and abettors in Wainewright's crime and should have been tried as such. In Lord Lytton's story, already referred to, the villain insures the life of an heiress in favour of one whose interest it is to have her live and enjoy her fortune, the villain being trustee. Such a transaction is a statable one and one that an insurance company might consider. But in the case in real life which we have been considering, the companies simply wagered with Wainewright $£ 18,000$ at odds that he dare not murder Miss Abercrombie and take the chance of being able to convince judge and jury that she died a natural death and that his interest in her life was an insurable interest under the law to the extent of $€ \mathrm{r} 8,000$. 
The other point in this case is that Wainewright, having found the death of a relative a most advantageous thing for himself, was allowed by the insurance companies to choose that identical person in the whole world over whose fate he could exercise the most complete control, and make that person's death a perfect gold-mine for himself. He chose a young and inexperienced girl, to whom he stood, in some sense, in the relation of guardian; he lured her to his own house; he allowed her to live until he had arranged to make as much as possible by her death; and then, at the most convenient time for himself, he presented her corpse as his certificate to claim from the gamblers on the other side an immense fortune. It is not often that such loose transactions in insurance come to light, and, probably, few so loose can be found in this day. But the very extremeness of the instance serves all the better to illustrate the principle. The warning is plain-that insurance is unsound in principle and dangerous in practice when the beneficiary under the policy has not a clear, understandable financial interest in the subject of the insurance. 


\section{CHAPTER XIII}

\section{LIFE INSURANCE - Continued}

Instances in Recent Years of Murder for Insurance Money-The ViauParslow Case-Horrible Fate of a Trusting Husband-Murder of a Young Woman by her Business Partner-Holmes and his Fearful Record-The Most Elaborate and Fantastic Crime of Modern Times.

$\mathrm{W}^{\mathrm{H}}$

HEN we come to deal with recent cases of murder for insurance money, unfortunately, we are in the same position as when treating of similar crimes of old days-the difficulty is not to find instances, but to choose from a sickening mass of such material those cases that best show the dangers that follow abuses of the life-insurance system and most clearly teach the need of public vigilance. To deal with such cases at all is by no means pleasant, particularly as the very fact that these crimes are of our own day gives us a nearness of view that makes us feel almost as if we were witnesses of the horrible events related.

Though life-insurance is a modern institution and flourishes best near the great centres of our civilisation, it is being pushed by active and enthusiastic agents into the remotest districts. This, in fact, is one of its dangers. Like " firewater" among the Indians, insurance among unsophisticated people is apt to show in exaggerated form all its bad qualities and none at all of its good ones. Judging by what we read of them, there is no class of people on the North American continent who are so well content to live their own lives apart from the so-called advantages of modern civilisation as the French Canadians. Yet it is amongst these people that we find to have been committed 
a crime which is spoken of in the official records as one of the most atrocious ever brought to light, and the cause of it was life insurance.

Homicide is a comparatively rare crime in Canada, and homicide by a woman is of remarkable infrequency. The death penalty is inflicted there, and the course of justice is terrible in its calm, yet swift and certain, descent upon the malefactor. The history of the Dominion of Canada shows but about half a dozen women as having been so clearly guilty of murder and so lacking all semblance of justification or even extenuation for their crime that the extreme penalty has been inflicted upon them. Of these, there is only one, perhaps, of whom it can be said that, even had the authorities desired to be lenient, public opinion would have clamorously demanded that the law be allowed to take its course, and that one was an unfortunate creature whose motive for crime was, in part at least, if not altogether, the desire to possess herself of life-insurance money. This was Cordelia Viau, wife and murderess of Isidore Poirier, of St. Canute village, County of Two Mountains, Province of Quebec.

Isidore Poirier was a contractor and builder in a small way. He married Cordelia Viau, the handsome, intelligent daughter of a farmer in the neighbourhood of his home. They had no children. For some time they lived happily, but at length the woman seems to have conceived aversion and contempt for her husband. She was a masterful woman, and Poirier seems to have been a man of very common mould. He was not great or strong enough to make his wife admire or respect him, yet was too obstinate to yield to her domination. The woman turned with every sign of affection to a man named Sam Parslow, who was a carpenter working for her husband, and who was even less strong-minded than Poirier. The relations between the wife and the workman soon became a scandal in the quiet village, not less so because the woman was the organist 
of the village church, while her paramour was a member of the choir.

The husband went to California for a time about three years before his death, and, while there, he was written to by the cure of his old parish to either come home soon or order his wife to go out and join him. Poirier, like the simple-minded man he was, sent the priest's letter to his wife with some words expressive of his perfect confidence in her. However, Poirier returned to Canada and resumed his old business at St. Canute. Parslow left the village about the time of the husband's return and went to Montreal. But, for some reason, he afterwards went back to St. Canute and was re-employed by the trustful Poirier. The wreck of his home and change of feeling toward him on the part of his wife were too clear for even Poirier to misunderstand his position. However, as might have been expected of such a man, he merely worked harder at his business and took to drink to assist him in forgetting his sorrows. His wife by no means attempted to prevent him from acquiring a taste for drink, but made the fact of his drunkenness a further excuse for her contempt and aversion.

While the relations of these people were as here described, Poirier insured his life for $\$ 2000$. That is to say, his life was insured for that sum. The man himself had very little to do with the matter: Madame transacted the business, carrying on all the negotiations and correspondence incident thereto. She took out two policies of $\$ 1000$ each. She made an attempt to keep each policy a secret from the company issuing the other, but does not appear to have succeeded. However, she asked for information and had it made clear to her that the policies would be paid at her husband's death, even though that death were the result of accident or of wilful murder. One would have supposed that the specifying of such conditions by a woman of Cordelia Viau's reputation would have put the companies upon inquiry at least, if it did not cause them at 
once and peremptorily to refuse the insurance. But the applications were accepted and the insurances granted. Moreover, the unfortunate husband's will was made, naming Madame as the sole beneficiary.

From this time Poirier was doomed. The murder took place on Sunday, 21st November, 1897, at the Poirier home in St. Canute. Poirier had been working at the repair of a church building at St. Jerome, nine miles distant from his home, and he remained at St. Jerome, at the house of a friend, on Saturday. His wife came to see him, bringing with her a child whom they had adopted. This child she left with the friends in St. Jerome, and drove back with her husband to their home in St. Canute. That afternoon, the woman and Parslow were at their places in church and assisted in carrying on the service. The husband had been drinking and was left at home. $\mathrm{He}$ was probably in a drunken stupor for the greater part of the afternoon. After vespers, Parslow drove over to Poirier's, tied his horse, and went into the house. The woman was seen to come out of the house, get into the rig, and drive away by herself. That evening, passers-by noted with surprise that there was no light in the Poirier house. It was Madame herself who gave the alarm next morning, telling a neighbour that she had not been able to get into her own house. One of the neighbours went with her, broke into the place, and found the dead body of Poirier with all the evidence about it of a life-and-death struggle with his murderer, and bearing six knife-wounds, three of them so grievous that any one would have caused death.

Parslow and the woman were arrested, charged with the crime, and put in separate cells. Each, fearful that the other would say too much, made an effort to exculpate himself, thereby incriminating himself and the other. At the trial, the evidence, though only circumstantial except for these partial confessions, was complete. It was not made quite clear that 
the woman was actually present when the deed was done, but, of course, this made no difference so far as her guilt was concerned. Parslow's subsequent confessions, read in the light of the qualities both he and his partner in guilt had shown, would go far to convince one that the woman was actually present and that it required her presence and her fierce, determined will to nerve the poor wretch to strike the fatal blow. Though there was a verdict of "Guilty" against both, a stay of proceedings and a second trial were allowed upon a technical point, this being, probably, due as much to the anxious desire of the authorities to give the woman every possible chance to exculpate herself as to any justice in the claim entered on her behalf. The second trial was held in December, I898, and resulted, like the other, in a verdict of "Guilty" against both prisoners. The sentence of death was pronounced, the date fixed for the execution being March Io, 1899. Notwithstanding that there was so little to be said in her favour, petitions numerously signed were sent to the Governor-General praying for leniency for the female convict. The advisers of His Excellency, however, decided to allow the law to take its course. According to the newspapers, the difference between the man and the woman who had thus taken the life of another was shown in their last miserable moments on earth. Sam Parslow was limp with fear of the hangman's noose, and had to be actually carried to the scaffold. But Cordelia Viau walked up the steps with a firm tread, and, on the fatal platform, she made but one request of the executioner-"Be quick!"

Turning to the next case of homicide that I have chosen as illustrating the points presented in previous chapters, we find ourselves in different circumstances entirely from those attending the tragedy just recounted. We turn to another country and to a large and rapidly growing city and find the people of the drama of real life which we are to follow wealthy, prominent, and cultured. The case did not gain equal notoriety with 
some others, and for this reason, and also because there are still many alive to-day for whom the public reiteration of the facts would be the reopening of a grievous wound, I take the liberty of changing the names of persons and places. By so doing, it is true, I weaken the force of the case as an illustration. I can only ask the reader to accept my assurance that the facts given, except for the names, are the precise facts in a case well known to those versed in the records of insurance crimes. My authority is a work-not official-summarising the newspaper reports of the time. I do not follow these reports in their sensationalism; otherwise I could add many a thrilling line. The facts, even concisely and coldly stated, are gruesome enough.

In a city, which I shall call Woodington, lived a man whom I shall call Thomas P. Wander, known to many as Tom Wander. He was the son of a wealthy father, and had plenty all his life. While a mere youth, he became addicted to gambling, and the fascination of the table grew upon him as he advanced in years. As a man he travelled throughout America, as far south as Mexico and Cuba, and as far north as Alaska, playing for high stakes in every gambling centre of importance. "Lucky Tom," many who knew him called him, because of some favourable strokes of fortune in his adolescent days. From gambling he graduated into counterfeiting, not as a producer of "green goods" but in "shoving the queer," to use the language of the craft. According to a confession attributed to him, he had stained his hand with human blood, the object being to gain the money of his victim.

Shortly before the events that made him notorious, Tom Wander was living in Woodington, occupying apartments in a flat-building owned by his father. He was a man of twentynine, handsome, fascinating, and, as his deeds were unknown, a favourite with many people and received in good society. Another occupant of the flat-building was a woman of about 
Wander's own age, whom we may call Miss Millie Hart. She was engaged in business on her own account as a dressmaker. She had handsome professional parlours in a prominent business block, had an excellent line of custom, and handled considerable sums of money. Miss Hart and Wander soon passed beyond the stage of mere acquaintanceship, and, at the time of the events about to be related, were regarded by those who knew them as lovers. All accounts agree that the woman was of pure life, and there is nothing to show that Tom Wander desired her otherwise. She was fascinated by the handsome, popular man, who paid her such devoted attention, and, after a time, entered into his gambling schemes. Just how their accounts stood it is impossible to say; but the probability is that Wander borrowed a good deal of the poor girl's money on the specious plea of using it to make them both rich.

But "Lucky Tom," like all gamblers, had times of ill-fortune, and about the time of which we speak, his funds had run very low. And, like many other gamblers, almost the last thing he thought of when faced by need of money was economy, and the very last thing in his calculations was giving up the excitement of high play. In his desperation, he conceived the scheme of insuring Miss Hart's life, with himself as beneficiary, and then murdering her. It seems pretty well established that the man was one of those human monsters who, having once given way to crime, have no guard against their passions. Outwardly like other men, he seems to have been a maniac in the utter want of balance of his moral nature. The elaborate nature of the scheme he prepared in order to win money by the death of one who trusted him, indicates that his mind had the preternatural yet unbalanced cunning of insanity. Yet it would be hard to say that he was morally irresponsible. He knew quite well that he was planning evil, though the thought of it did not affright him as it would a man of normal mind. After careful inquiries among insurance agents and brokers, 
Tom Wander arranged a real or pretended-(probably the latter)-loan from himself to Miss Hart, and, to cover this, he arranged for a chattel mortgage on her stock. While this was being prepared he induced the woman to insure her life and assign the policies to him to the amount of the loan as collateral. The policies were, one for $\$ 5000$ and another for $\$ 2000$, the latter being an accident policy. There was no other motive for murdering her alleged or even suspected than the desire of this monster to possess himself of the insurance money.

In the flat-house in which schemer and victim had their respective apartments was a man of foreign birth, one Faber, poor, hard-working, and evidently simple-minded. He also had rooms in the house, where he, his wife, and their family had their home. He was the engineer and furnace-man of the institution. This man Tom Wander got into his power -just how does not seem quite clear. Threat to expose some deed of his previous life may have been sufficient in the case of so poor a creature. Hypnotism also was alleged, but there is no evidence to prove it. The man himself said that Wander had threatened to murder his wife and he agreed to do anything rather than live in fear of any harm coming to her. It seems almost incredible, however, that any man should be weak enough to be led to murder an innocent woman by such a silly threat as that. The fact may have been a mere combination of two scoundrels, such as is often presented on the stage-the heavy villain in genteel clothing directing the hand of the low-comedy villain who is to "do the deed of blood" for vengeance or sordid gain. Whatever may have been the relations of these two, certain it is that they together took the life of poor Millie Hart.

The scheme arranged, as already suggested, was a most elaborate one, so far as the efforts made by the chief plotter to hide his own tracks were concerned. Miss Hart, apparently, had been led from gambling into counterfeiting, and had this 
added and greater reason for keeping secret the transactions between herself and Wander. On the evening of the $3^{\text {rd }}$ of December, I894, Miss Hart took out a rig from a livery stable, telling the man who drove the rig to her place to be sure not to let Tom know that she was driving out. This she did, apparently under direction of Wander himself, having been informed by him, probably, that the business of the evening was of a character to lead to trouble with the police if discovered. Whether the poor girl thought they were to drive out to the country and dig up some buried "boodle," or interview some fellow-conspirators in relation to a new issue of counterfeit money, or what may have been the lying excuse by which she was lured to this long, secret excursion will never be known. At a certain corner she was met by Wander and Faber. "This man is one of the gang," said the chief plotter of the other. Faber then got into the rig, and, taking the reins, drove for the open country with his victim. Faber had a revolver carefully chosen and elaborately prepared for that night's work, and also bullets which would better fit another revolver and so throw the hound of suspicion off the scent of guilt. But the precaution of changing the bullets seems not to have been actually taken by the assassin, and the bullet became one means of tracing the chief plotter of the deed. Faber had also been primed with whiskey, and seems to have been in a condition of alternate bloodthirstiness and fear. At a lonely place in the road, Faber placed his revolver at the girl's head and fired, killing her instantly. For a time he drove on with the corpse beside him, sick with fear and horror. Rousing himself, he pushed the body out and left it where it fell. Then, after driving farther, he abandoned the rig, walked into town and rode in one street-car after another, either dazed with his own conflicting emotions and with the stimulant he had taken, or trying, in confused and clumsy fashion to get out of the line of suspicion. 
Meantime, the chief plotter, Wander, had been hard at work, cunningly seeking to establish a basis for an alibi. He moved about swiftly from place to place where he would be seen by those who would be able to identify him with certainty. $\mathrm{He}$ accomplished wonders according to the testimony afterwards adduced, and, had it not been for other circumstances, might have been able to clear himself in court, however strongly condemned by public opinion. The greater part of the evening he spent at the theatre, in company with a lady friend upon whom he had called a little late for the rising of the curtain, but not so late as to cause her to decide that it would be unwise to go. In making this call, he was seen by the young lady's father and mother, and their evidence afterwards was one of the strongest points in his favor. There was nothing in Wander's demeanour to indicate that he had just plotted successfully one of the most cruel murders ever perpetrated or that he had been rushing about to show himself to acquaintances who might afterwards testify to the fact. This desperate gamester was playing his hand with the nerve and coolness he had often exhibited when money, almost as valuable as life to him, was at stake.

His plan was too complex, however. It is not in the nature of things that a man can make so many fine plans and have them all work in like the parts of a machine that has been " trued up." Though he had carefully covered each foot-print in the labyrinthine course he followed, he had not by any means thereby freed himself from suspicion. Superhumanly cunning himself, he seems to have assumed that the world would play the game he was engaged in according to his own method, and would not count him as caught unless it could trace him step by step from his public reputation to this " murder most foul." He forgot that suspicion does not move by careful tracing of clearly related steps, but at a bound and by an instinct of its own. Though he had concealed so much, 
he forgot how much was known. His relations with Miss Hart were known to many; his gambling habits and the desperate condition of his finances were subjects of discussion among his friends; the cruel character hid by his fine exterior was plain to everybody who was familiar with him. These things were not discussed in the public press or made matter of record in the city hall, but they were little isolated heaps of distrust which the murder touched into flames of suspicion, and by that flame the murderer's face was revealed.

The night of the murder had not passed before Wander was under suspicion; the very day following, he was put through the cross-examination known as " sweating" by the police, and was practically denied his liberty by the cordon of detectives and watchers placed about him; within three days he was arrested under formal charge of murdering Millie Hart.

From that time he was never again at liberty, and never for a moment did public opinion swerve from the belief that he was the guilty man. His elder brother, to whom he had confided more or less of his plans at a time when he entertained hopes of that brother helping him in carrying them out, but who shrunk with the horror of the non-criminal mind from such dastardly schemes of money-making, was also arrested. Faber, upon whom suspicion rested by reason of previous talk of the arch-plotter himself, was gathered in at the same time. The testimony of these two- " tainted " evidence, to use a legal phrase, but sufficient when corroborated-was the principal testimony against Tom Wander. Both made full confession. But the one thing that stood out plainly regardless of what oral testimony might be produced was that Tom Wander was the only person in the world who could have any motive for killing Miss Hart, and this motive he himself had laid bare when he carefully and anxiously arranged that her death should bring him seven thousand badly needed dollars.

The trial of Tom Wander lasted for seven long weeks. The 
prisoner was defended by the ablest lawyers in the country, for there was plenty of money behind him. Judge, jury, and lawyers did their duty admirably, notwithstanding the fearful physical and mental strain to which they were subjected by so long a trial. Counsel for the defence seemed to be hampered by the record of their man. Had he been other than he was, they might have outlined some theory to account for his conduct on that fatal night. But with such a man, apparently, they had no point to which they could turn without implicating him in other crimes and, probably, implicating others as well.

To his credit be it said-little enough, but for the sake of humanity let his memory have the benefit of it-he was true to his gambler's creed and refused to make known the perpetrators of other crimes, though by so doing he could at least have had that relief in his misery which company proverbially brings. The verdict of the jury was the only possible one"Guilty" -and the death-sentence followed as a matter of course, for there was nothing that could possibly be urged in extenuation or palliation of the offence. Efforts were made to have the execution of the sentence deferred, the plea being made that the prisoner was insane. This plea was denied by the courts and by the executive, to whom severally it was addressed. The prisoner may not have been insane as that word is understood in legal phrase as a justification for refusing to inflict the death-penalty; but he was clearly not a normal being. It may have been his own fault, in that he did not restrain his passions while he might yet have controlled them. Whosesoever fault it was, or however we account for it, only one whose mental balance was imperfect could have been led into such outrageous and easily detected crime as that of which Tom Wander was guilty. The sentence was carried into effect at the time first fixed. The man seemed to enjoy, even on the scaffold, the notoriety he had achieved, and died with an as- 
surance to the executioner, couched in gambler's phrase, that he would not flinch.

The fame of the case the facts of which I have given in the foregoing narrative is not very wide; but in the community in which the events occurred there was the most intense interest in every detail, as was natural enough. Throughout the trial, the enormity of the prisoner's motives and actions was dwelt upon in the press. But the fact was not pointed out that the relations of this man to his victim though not publicly discussed before the insurance was effected, might have been learned by the insurance people, and that, with the facts known, the absurdity of giving him the position of a beneficiary to the extent of seven thousand dollars by her death would have been clear. It is not enough that ordinary banking precautions were taken, for these are not matters of ordinary banking, but matters of life and death. Two people lost their lives over this affair, and others were utterly ruined. Put it on the very lowest plane of public policy and note that the whole community was bedevilled by the publication of the details of this crime, and that it cost the State not less than fifteen thousand dollars to bring the guilty parties to justice and punish them according to law. Is it possible to argue that the public has no such interest in these matters as to establish its right to call to account in some way those who furnish the motive without which such crimes would never take place?

With the recounting of one more case of crime, this, in some respects the most distasteful, part of my task will be finished. The reader is asked now to consider the case of Herman W. Mudgett, alias H. H. Holmes, the murderer of Benjamin F. Pitezel and his children. The records will be searched in vain for a more terrible story or one that more rudely shocked public feeling as the facts were brought to light. And this also was a case in which the principal motive, almost the sole $\underset{\mathrm{r}}{\operatorname{motive}}$ for the crimes exposed was the desire of the criminal 
to possess himself of the money to be paid by the life-insurance company on the death of his victim. When such complex and almost unimaginable crimes as this can be shown occasionally as the work of insurance, what shall we say of its possibilities of evil day by day and in the ordinary course of its operations?

Holmes-that being the name by which he is known in the criminal records and in the horrified recollection of those who followed the events of which he was the centre-was a native of New Hampshire and of respectable family. He had the advantage of a good education and showed the benefit of it in manhood so far as intellectual qualities were concerned. $\mathrm{He}$ was a man of very decided ability, and, had he been less bent upon having his own selfish way regardless of the rights and interests of others, or had he had more of the combination of the energy that works and the patience that endures which we call " ballast," he might have made a name for himself as a capable and successful man in the ordinary walks of life.

As a young man, he worked, as other men do. The occasion of his first violation of the law is not certainly known. The newspapers of the time say that the idea of fraud as a means of livelihood was first suggested to him by seeing how easy it was to collect life-insurance money on a merely bogus claim. There is nothing in the official record, however, to show that this was the case. Nor is it clear why or when he first assumed the name of Holmes. We find that he was married under that name in 1887 . This was only a form of marriage, for he had a wife then living, a New Hampshire woman whom he had married before he was of age. A month after his second marriage, he sued in the courts of Chicago for a divorce from his first wife, but did not prosecute the suit and his plea was thrown out. He made a third venture in matrimony without preliminary divorce, though both the women who claimed him as their husband were living. This third marriage took place in Denver, Colorado, in 1894 . 
About this time we find him engaged in business with Benjamin F. Pitezel. Holmes was clearly the superior man in everything that tends to success in business. He was, in fact, a man of most unusual energy as well as ability, and he took the position of leadership as by natural right. Pitezel had not the force of character to enable him to play any except a secondary part in company with one of Holmes's character. Pitezel was either an inventor or an exploiter of inventions. He met with some success, but, like many others of his class, he seems to have had more in prospect than in realisation. We find the two men in Fort Worth, Texas, in 1894, where they engaged in a real-estate speculation, using land owned by a woman who was a cousin of Holmes. Later in the same year, Holmes got into trouble in St. Louis. He was thrown into jail on a charge of selling a property which he had previously mortgaged. The mortgagee in this case was one Brown, supposed to have been Pitezel under an assumed name.

It was while thus incarcerated that Holmes met the man who was the primary cause of exposing the great crime by which Holmes will be long remembered-a prisoner named Hedgepeth. To this man Holmes-most strangely for one of his secretive nature-confided his intention of carrying out, in conspiracy with others, a great fraud upon an insurance company. This gives a hint of the "business" transactions in which these men were engaged. Pitezel had troubles of his own over some checks in which he and Holmes had an interest. This was in Terre Haute, Indiana. It is not on record that Pitezel was convicted of felony or sent to jail. The difficulty must have been patched up in some way. The partners engaged in insurance frauds, if we may trust the admissions of Holmes's counsel in the great trial which afterwards took place. Just how many of these frauds there were or what their extent is not known. The ventures must have turned out very successfully to cause them to repeat the experiment. 
The form of fraud seems to have been to insure one of the partners, then spread a report of his death, providing a suitable corpse and the necessary affidavits as to identity to deceive the insurance company. The last affair of this kind in which they engaged and which cost the lives of five people, including the chief conspirators, was one based upon a policy for ten thousand dollars, issued in November, I893, by a prominent American concern, through its Chicago office, on the life of Benjamin F. Pitezel. In this case we find Pitezel using his own name, though he had previously gone under at least one alias, and, at the time of his death, as will appear as we proceed, he was using another. Holmes, who seems to have had a new name for every set of people with whom he was brought in contact, was known at this time as Henry Mansfield Howard, being forced to use that name over a considerable portion of the country and in communication with a good many people by the fact that his third wife travelled with him more or less and always spoke of herself as Mrs. Howard, using the name to which she supposed she had a right. Even in this case, however, the twist in Holmes's nature would show itself, for he used an alias while in Fort Worth, though his third wife was with him, being known there as D. T. Pratt. He told the woman that squatters were upon a ranch upon which he, as Howard, had a claim, and that if these free citizens of the glorious South-West knew that such a claimant was on the ground, they might seek to perfect their title by means not wholly conducive to the health of the claimant aforesaid. In the course of the few remaining months of his career as a free man, Holmes had a new alias, on the average, about once a day.

Reverting to the insurance upon the life of Pitezel, it is to be noted not merely that it was made out in Pitezel's own name, but that it was made payable to his wife. This meant that in case of his death ten thousand dollars would be paid to 
Mrs. Pitezel and not to Holmes or another. It seems from this most probable that Holmes had not at first any intention of doing away with his partner, for, otherwise, he would have made arrangements giving himself a more direct interest in the insurance. He evidently intended merely to share in the profits of the fraud, trusting to the proverbial "honour among thieves" for his share from the supposed widow when Pitezel should have disappeared leaving a substitute corpse as the certificate of his death. It would have been easy for a man of Holmes's ability to arrange that the money should be paid to him. He and Pitezel were in partnership, and each might fairly have insured his life for the benefit of the firm. Or, Pitezel being a weak man in his hands, he could have arranged a pretended loan, taking Pitezel's note with an assignment of the insurance as collateral security. Even allowing for the perverse love which the criminal mind shows for the making of difficulties merely for the pleasure of overcoming them, it is fair to suppose that Holmes entered upon the transaction with no other idea than that this was to be one of many such strokes of "business," past and future, in which Pitezel was to go on dying for insurance money until he had reached a wealthy, honoured, and advanced old age.

The partnership, however, was not altogether a peaceful one. Pitezel drank more or less heavily. There were times when this suited Holmes's purpose very well, but there were times also when it proved very awkward in the fine financial jugglery he was always carrying on. The man must have seemed heavy-witted and bungling to one of Holmes's glowing imagination and ready adaptiveness. Another fact was that Mrs. Pitezel was mortified and greatly troubled by the course her husband was led to pursue. It was necessary that she should be informed of the intended fraud, for she would raise an outcry if she learned that. Pitezel was no more and did not know that it was another case of Kipling's Fuzzy-Wuzzy-"'e's 
generally shammin' when 'e 's dead." She had five children, some of them well-grown; and it was necessary that these young persons should be schooled to just such a show of grief at the supposed death of their father as would help in deceiving the insurance company while not leading them to ask Mr. Holmes unnecessary and perilous questions. Generally uninformed as to her husband's business, feeling that she did not know to what extent he had already committed himself by his shady transactions or what power Holmes might have over him, she could not well refuse to play the waiting part assigned to her. But it is evident that the idea of gaining money by such methods as those her husband and his partner resorted to was repugnant to her. The effect of all this was to make Holmes, in her eyes, the ruler of her fate. Distrusting, she wished to be rid of him; but fearing to take any step to incur his ill-will, fearing even to do or refrain from doing anything which would tend to disarrange the plans upon which the freedom of her husband might depend, she fell more and more into his power. The knowledge of this fact, his growing dislike for and distrust of Pitezel and his own pressing need of money, probably combined to lead and drive Holmes to the course which made him one of the most remarkable criminals of any age.

Soon after the insurance upon Pitezel's life was effected, the partners decided upon Philadelphia as the place for the carrying out of their scheme, probably because it was the headquarters of the company with which the insurance had been placed. Accordingly, they foregathered there in August, I894. Holmes, as Howard, came with his new wife and took rooms in a boarding-house. To some people, perhaps through misunderstanding as to pronunciation, he was known as Howell. Pitezel, under the name of B. F. Perry, rented an office and living rooms in a building on Callowhill Street, and began, nominally, a business as a dealer in patent rights. Holmes was 
seen about Pitezel's place and was known to be very intimate with him. He accompanied Pitezel when the second-hand furniture with which the latter's office was outfitted was bought. Holmes informed his wife that his business in Philadelphia was to sell a patent letter-copier, one of the people with whom he was negotiating being the representative of the Pennsylvania Railroad Company. Later, when the insurance money was coming into his hands, he was able to account for it, as well as for a trip to Philadelphia which he had to make, by telling his wife that the railroad company had bought the concern and was ready to pay the money at call.

It was on the $7^{\text {th }}$ of August, I894, that Pitezel entered into possession of his quarters on Callowhill Street. Up to September Ist, he was seen about the place by many people. On the evening of that day, which was Saturday, he called to see Holmes at his boarding-house. That day, he bought two haltpints of whiskey at a saloon near his own place, having first learned that the saloon would be closed on the following day. This was Pitezel's last night on earth. On Sunday, the and of September, Holmes informed his wife that his caller of the previous evening was a messenger from the railroad company who had left word that Holmes would be allowed an interview with an official of the company in his suburban home that day -Sunday. Holmes told his wife that if he closed the deal they would leave Philadelphia that evening, their week at the boarding-house being up and he having business elsewhere. He left the place alone about half-past ten in the morning, and did not return until four in the afternoon. He carried out his promise to his wife-they left town that night and the following day they were in Indianapolis.

Callers at Pitezel's place on Monday did not find him, although the place was open. On Tuesday, the $4^{\text {th }}$ of September, his dead body was found in an upper room. There was evidence of an explosion, as of benzine, a shattered bottle 
being found and the clothes on the body being partly burned. Yet, as the case was examined and considered, a very strange and complex condition of affairs was discovered. The broken pieces of the bottle, which was supposed to have exploded, had fallen into the lower part of the bottle itself, instead of being scattered about the room-proof that there had been no explosion. It was shown at the post-mortem examination that the man had actually died of chloroform poisoning. Yet there was a quantity of chloroform in the stomach which, the doctors united in testifying, had been injected after death, the position of the body and the condition of the intestines showing that it could not have been self-administered by the deceased. These facts were not all known at first, or their bearing was not understood, for there seems to have been no suspicion that the man had been murdered for insurance money. When found, the body, but especially the face, had already begun to decompose, mainly, as the doctors explained, because the corpse had been so placed that the sun, through the long, hot August day, would shine upon it direct or be reflected upon it from the tin roof of an adjoining building. If this indicated design on the part of the murderer, it was a design devilish in the wisdom of its conception and in the ingenuity with which it was carried out.

Holmes went to see Mrs. Pitezel in St. Louis, and told her that "Benny," as her husband was called, was all right, and not to worry. But the woman evidently did worry, and was fearful of all manner of evils to result from the criminal traffic in "stiffs" and insurance policies. At this point the fine work which Holmes carried on for so long undetected really began. With three wives living and a partner found dead under circumstances likely to arouse suspicion, he was already deeply enough involved to keep an dinary criminal busy in dodging the law. But Holmes plunged into an additional series of criminal operations, most horrible in their nature, and yet car- 
ried on with such boldness, dexterity, and-up to a point-success, that even our horror yields in part to a gruesome wonder and interest if not downright admiration for the talents of the man.

He sent Mrs. Pitezel to an attorney to press her claim upon the insurance company, warning her to make no fuss if she valued her husband's liberty. To make the claim good, identification of the body was necessary. But, of course, if Mrs. Pitezel herself went to Philadelphia and saw her husband's body, even though the body had begun to decompose, she would recognise it and would know his actual fate, and it would be useless for Holmes to tell her, as he had already done, that "Ben" was making a wide tour and would arrive home by way of Puget Sound. Holmes arranged, therefore, to have one of the children, Alice go with him to see the body. Mrs. Pitezel was sick, and, besides, she did not wish to assist by perjury - as she supposed she would be called upon to do in swearing that a bought corpse was that of her husband-in the fraud she believed Holmes to be carrying on. So, poor little Alice Pitezel was drawn into the devil's dance which Holmes had begun, the story of which reads like the drug-wrought imaginings of some decadent Poe.

Leaving St. Louis after having instructed Mrs. Pitezel as to the course she was to pursue, Holmes rejoined his third wife in Franklin, Indiana. He travelled from that point in different directions for several days, sometimes with and sometimes without his third wife. In the course of one of these trips alone, he visited his second wife in Willamette, Illinois. The purpose of this visit will at once appear, and the success of his scheme shows how finely this erring genius calculated his course. In consequence of the claim made upon them from St. Louis, the insurance company communicated with their Chicago branch. In the course of an effort to discover the facts, a representative of the Chicago office called at Holmes's house 
in Willamette, and, not finding him there, left word with wife No. 2 that information was wanted concerning Pitezel, alleged to have been Perry, and believed to have been an acquaintance of Holmes. This inquiry the Willamette wife communicated to Holmes by mail. In this way Holmes was drawn into the case in a perfectly natural way. He wrote to the company that he had known Pitezel and was aware that Pitezel had gone under the name of Perry. He said also that he would soon be in Baltimore on business, and, from there, would go to Philadelphia and give the company the benefit of his information. Giving his third wife the story about the patent copier and the Pennsylvania Railroad, Holmes started East on the Igth of September. Arrived in Philadelphia, he met at the insurance office the lawyer and Alice Pitezel, who had come on from St. Louis to advance the claim. Pitezel's body, which had been hurried to the Potter's Field, was exhumed and identified. What poor little Alice Pitezel thought it is not easy to make out. She could hardly have doubted that the body shown to her was really that of her father; and yet she also was completely in Holmes's power, and even her letters to her mother do not betray any guilty knowledge of the facts of the case, much less any suspicion of Holmes-or Howard, as he was known to her. The secretiveness of the arch-conspirator is shown, however, by the fact that, almost from the first, in her letters Alice used a cryptogram-" 4-18-8"-instead of his name when speaking of Holmes.

Having made their affidavits before the coroner as to the identity of the body, Holmes and Alice Pitezel left for Cincinnati on the $23 \mathrm{~d}$ of September. On the following day, the case being, as it supposed, completed, the insurance company paid over to Mrs. Pitezel's lawyer the amount of the policy less expenses, the sum handed over being in excess of $\$ 9700$. Holmes left Alice Pitezel in Cincinnati, with instructions to join him within a day or two in Indianapolis, and went to St. 
Louis. He induced Mrs. Pitezel to allow him to take Alice's younger sister, Nellie, and her little brother, Howard, to Indianapolis to be company for Alice. At this time, as later, he frightened the poor woman by telling her that great secrecy was necessary in the interest of her husband, as discovery of the fraud which she believed to have been committed by Pitezel would lead to his arrest and imprisonment. At the railroad depot, when he was leaving for Indianapolis with the three children, he met the lawyer who had come back with the company's settlement. On the strength of what was coming to Mrs. Pitezel, Holmes got ninety dollars from the lawyer to pay his and their expenses, and he also requested the lawyer to give Mrs. Pitezel money on account that she might have enough for household demands. The lawyer gave her five dollars. Instead of remaining in Indianapolis, Holmes took all the children to Cincinnati, where he registered the party as "Alexr. E. Cook and 3 children."

A few days, after that, Holmes, Mrs. Pitezel and the lawyer met in the lawyer's office in St. Louis for a settlement among themselves and a division of the money received on account of Pitezel's insurance. There was a difficulty at once about the lawyer's bill. Holmes was completely moved from his usual calmness by a demand on the part of the man of law for $\$ 3000$. He urged, in fact, commanded, Mrs. Pitezel not to agree to it and not to sign any paper that might be offered to her by the lawyer. Some question was raised as to Holmes's locus standi in the case. The bill for legal services was compromised at $\$ 2500$. The balance of the money, mostly in fifty-and hundreddollar bills was paid to Mrs. Pitezel, being received by her in a common shopping-bag. It was evident throughout that she was grieved and distressed by her position and that she thought far more of the fraud and disgrace than of the financial advantages gained. Apparently she would have been well content to leave all the money to the lawyer, but she was dominated by 
Holmes's commands. The moment the money was paid to her Holmes demanded $\$ 400$ on the plea of paying some debt of her own or her husband's. This arranged, Holmes said they must go over to the bank to pay off the note for $\$ 5000$ on the Fort Worth property in which he and Pitezel had a joint interest.

The poor woman asked no questions and suggested no difficulties. Evidently, her nerves were completely unstrung and she seemed ready to accept any excuse to get rid of the money thus dishonestly come by. Arrived at the bank, Mrs. Pitezel opened her shopping-bag and allowed Holmes to take what money he would. Counting out a sum which he said was $\$ 5000$, Holmes left her at one side of the public countingroom, while he went around a corner of the counter to a distant wicket, where he pretended to transact the business of paying the note. He returned to her in a short time and gave her a paper in the form of a note signed by her husband. The document was not negotiable and was quite worthless. No doubt it was one of many papers which Holmes had in his possession bearing the same signature, given to him to complete and to "kite" if he could. The paper, of course, had never been in possession of the bank. It is probable that the note for $\$ 5000$ on the Fort Worth property was a mere figment of Holmes's creative imagination. Had Mrs. Pitezel had the slightest interest in the money in her possession, had she had a trace of self-assertiveness, she would have upset the schemer's plans at this most critical point. Here again we cannot but marvel at the skill with which he calculated his chances and made circumstances bend to his will. There were other transactions which it is not necessary to follow. The net result of all was to divide the money won by Pitezel's death about in this way: Lawyer, $\$ 2500$; Holmes, $\$ 6700$; Mrs. Pitezel, $\$ 500$.

Business affairs adjusted in this business-like fashion, Holmes advised Mrs. Pitezel to leave St. Louis and visit her mother in 
Galva, Illinois. This she decided to do. She took her baby and her eldest daughter, Dessie, with her. Soon afterward, Holmes and his third wife started to travel. Thus there were three parties in this strange group-the three children in one; Mrs. Pitezel, Dessie, and the baby in another, and Holmes and his third wife in the third. The plotter joined the other groups whenever he found it necessary to do so in the course of the necromancy in which he now engaged.

While the children were at Irvington, Illinois, in a house which had been rented for them by Holmes-who said he wanted it for his sister, Mrs. A. E. Cook and her childrenpoor little Howard Pitezel disappeared. The remains of his clothing were afterwards found in a stove that had been set up in the place. Holmes was never tried for this murder, nor was any evidence concerning it allowed in his trial for the murder of Pitezel. Evidence to establish his guilt was collected by the Commonwealth of Pennsylvania, however, and the District Attorney, who had charge of the case, offered it in court. We hardly go a step beyond the official documents, therefore, in ascribing this almost unthinkable crime to Holmes. But we do not find the motive for it to have been the desire to have and securely enjoy the insurance money, unless we assume that Alice had confided her knowledge or suspicions as to the death of her father to her brother and the boy had impetuously threatened to give Holmes trouble. The theory of the Commonwealth was that Holmes had made up his mind to gain sole possession of the Fort Worth property, and was prepared to remove not only his partner but all his heirs with that end in view.

Holmes's purpose evidently was-by whatever reason dictated - to kill these people off one by one, first taking them to places where they were not known and amongst people by whom they would not be missed. In pursuit of this plan, we find him managing with almost superhuman skill the two 
groups into which he had divided the family. To facilitate his horrid business, he must keep the two groups near together, yet he must not allow any member of either group to see a member of the other. The best way to accomplish that purpose was to keep them on separate trains moving in the same direction or in hotels from which they were not likely to move far. He took his wife with him, for what reason it is not easy to see, unless he was insane-which seems likely-and took a perverse pleasure in making his diabolical jugglery as difficult as even his soaring imagination could pattern. Mrs. Holmes (third) knew nothing about the snake-charmer's dance in which her husband was engaged, but supposed that he was travelling in the pursuit of some legitimate business.

On the $3^{\text {rd }}$ of October, we find Holmes and his wife in Detroit, and to that city on the same day come the children Alice and Nellie. Holmes wrote to Mrs. Pitezel to come with Dessie and the baby to Detroit, that "Ben" was waiting there to see them. Pursuant to this letter, Mrs. Pitezel and the others went to Detroit. Thus the thaumaturgist Holmes had his three parties in the same city, none aware of the presence of the others. Of course, "Ben" was not there. Holmes told the poor wife some plausible story to show how necessary it was for him to go away at that particular time, but assured her that he would meet her soon. Though heartsick for the sight of her husband, though dreading the mystery by which her life seemed to be surrounded, the woman was obliged to content herself with the poor promises made to her. Before departing from Detroit, Holmes left a mark which gives us a shivery sense of his calculating deviltry. This mark was in the shape of a hole four feet long, three and a half feet wide and two and a half feet deep in the rear part of the cellar of a house which he had rented.

From Detroit, he went to Toronto, Canada, taking his strange, disjointed caravan with him. The three parties were 
registered at three different hotels. The magician's plans were in the most imminent danger of upset at one time, and were only saved by a chance meeting on the street between him and Mrs. Pitezel. But for this meeting, it is likely that mother and children would have come face to face. But Holmes was warned in time and succeeded in getting the children out of the way. In Toronto, also, Holmes rented a house; and in the cellar of this house also he dug a hole.

There were only two sections of the plotter's party to leave Toronto. The remains of the poor little girls, Alice and Nellie, were found in the hole which he had dug. The Commonwealth of Pennsylvania afterwards offered evidence to prove that Holmes had borrowed a spade of a person in Toronto, to dig a hole "to store potatoes" as he said. The reason for removing Alice Pitezel, who had seen her father's dead body, is obvious; and it was safer to put her sister out of the way also, as her presence would certainly complicate matters, and, besides, there is no saying what she may have learned from Alice about the identity of the corpse in Philadelphia. Before leaving the subject of these poor children, it ought to be explained that they and their mother wrote many letters to each other. These letters Holmes received and kept. He gave each party, through alleged interpretations of fictitious letters in cipher, such information concerning the others and concerning the absent husband and father as he thought in his own interest. The genius he displayed in these complications of deceit was wonderful.

Holmes and his wife and Mrs. Pitezel and her two remaining children went to Prescott, Ontario, whence they crossed the St. Lawrence River to Ogdensburg, New York. Their stay there was short, and when they left they went to Burlington, Vermont. Here again Holmes rented a house. He seems to have had some wild scheme for getting rid of the remaining members of the family, and attempted to prepare for them in 
the usual way by digging a hole in the cellar. His plans miscarried, however. Being now in his native New England, he coolly went to visit his parents in Gilmanton, New Hampshire, and also resumed relations with his real wife. His ingenuity was severely taxed to account for his long absence and silence; but he proved equal to the occasion, and no suspicion was aroused. Meantime, the third wife was in Boston, whither Holmes went to join her on the $I$ th of November.

Meantime, unknown to him, his unwise confidence in his fellow-prisoner in St. Louis had joined with his other mistakes to point to him as the defrauder of the insurance company. Hedgepeth had advised the Chief of Police of St. Louis of what Holmes had told him about the intended fraud. This information being communicated to the company, investigation was undertaken and evidence was unearthed which was regarded as sufficient to justify the arrest of Holmes. Not only he, but Mrs. Pitezel also was arrested, the charge being conspiracy to defraud the insurance company. To comply with some formality of the law and hold Holmes pending investigation, another charge was made against him of fraud in connection with the Fort Worth transaction. Holmes elected to go to Philadelphia and stand his trial on the charge of conspiracy in the insurance matter. While he was in custody facts transpired which indicated that the crime was a still blacker one. The suspicion that this was the case was helped on by the absurd lies that Holmes told in the course of several partial confessions made to the police. Detectives were put on the case, and Holmes's doings, both before and after the insurance, were made known. Among other traces of his fearful career were found the remains of the Pitezel children in Irvington and Toronto.

As the facts came to light it became evident that life insurance had gained the distinction of having given incitement and direction to the greatest criminal genius of our time, a man so devilish in his doings that the only way by which we can avoid 
dishonouring humanity by calling him a man is to believe that he was mentally unbalanced and did not understand in the same sense as ordinary people do such ethical considerations as the rights of others, the sacredness of human life, and the duty of the powerful to the weak.

For almost a year Holmes remained in jail before being tried. He was then arraigned on the charge of murdering Benjamin F. Pitezel. In the course of the trial, he quarrelled with his counsel, - as if his case was not already desperate enough or his difficulties great enough,- -and, dismissing them, took charge of his own case. Mere cleverness on his own part, even education sufficient to enable him to cross-examine, as he did with marked ability, the medical witnesses, would not make up for lawyerskill, which, like other skill, is the outcome of practice, and Holmes was obliged to ask his defenders to return to his aid. The case was hopeless from the first. The lawyers did all that could be done for the prisoner. Not only did they exhaust legal skill in dealing with the evidence, but they presented every plea that could help to avert the dreaded verdict of "Guilty." And, even when the verdict was at last rendered and sentence of death pronounced, they did all in their power to delay, and, if possible prevent the execution of the sentence. But the prisoner was found guilty, application for new trial was refused, and Holmes was hanged in the Philadelphia County Prison, on the 16th of May, 1896.

Without desire to delay the reader with mere moralising, I would like to point out that in this case all the outward forms which should guard a life insurance contract were complied with: The amount insured was not excessive; the health of the insured was good and his habits apparently passable; the policy was in favour of the wife and not in favour of some creditor whose interest in the life of the insured was not clear; no unusual conditions seem to have been asked or granted; the policy was issued from an office which had opportunities-and 
might fairly be supposed to have used its opportunities-to learn the character and circumstances of the applicant. But, notwithstanding the favourable appearance of these merely formal considerations, the risk was essentially bad, and due inquiry, if it had not revealed its badness would at least have aroused such suspicion as to cause the company to refuse the insurance. The consequences of error in this matter were those set forth in the account of this sickening case. When the consequence of error may be not merely a series of fearful butcheries, but the bringing to the height of his worst powers a wonderful genius in crime, and the expense to the State of following him over half a continent, it is hardly unfair for society to demand that those who do for it the work of caring for the helpless, shall do that work in cleaner and more workmanlike fashion. It may be argued that, even with the greatest vigilance it is impossible to avoid errors. This may be a good plea as excuse for the mass of error, but the individual or the company that seeks shelter behind such a plea is merely justifying carelessness and blundering-and in this, as in so many other cases, a blunder is worse than a crime. 


\section{CHAPTER XIV}

\section{LIFE INSURANCE-CHILDREN}

Covering the Lives of Children-Social Conditions which Gave Rise to the System in Great Britain-Early Suspicion of Child-Murder for Insurance Money-Investigation by Parliament.

$\mathrm{W}^{\mathrm{E}}$

come now to a branch of our subject which I would willingly leave untouched, if that could be done without spoiling the record by incompleteness. But, to deal with the crimes of insurance and shrink from dealing with the most horrible of all, that of procuring the murder of helpless babies would be to draw an indictment and leave out the principal count. In that which follows on this subject, I deal only with events in Great Britain. That does not necessarily mean that such crimes are confined to that country and that insurance elsewhere can show a clean record. It only means that in this case, as in others, we deal only with one example of a given evil, and we seek that example where the facts are plainest and the records most easily searched. Let it be noted, before we proceed further, that, with the single exception of marine insurance abuses, there is no branch of our subject in which we are so much in danger of being misled or in which it is so necessary to make sure of our facts. The reasons for this are mainly two. On the one side, our horror and indignation at the crimes alleged may make us ready to prejudge the case; on the other side, our tendency to neglect things which do not immediately concern our own welfare may cause us to accept too readily any strong denial or specious explanation. Avoiding 
alike premature indignation and unwise credulity, let us examine and consider the facts.

First, however, the background for our facts, in order that we may see them in just proportion. The Britain of the eighteenth and nineteenth centuries was wholly different in its circumstances from that of earlier times. The application to industry of individualistic ideas, the throwing aside of the power of the war-lord or king and the spirit-lord or priest, had greatly increased industrial production. Inventions multiplied, knowledge spread, and the country rapidly grew wealthy. At the same time, the conditions being new, misunderstood, and uncontrolled, there was anarchy in respect of those conditions, tempered only-and sometimes not tempered but aggravated -by the traditions of trades and the ill-considered acts of an interest-ridden Parliament. Even assuming, as all who have opinions on the subject seem to assume, that the state of affairs was, on the whole, an improvement upon that which had preceded it, of course it was not wholly without disadvantages. Formerly, the people remained in the country districts and lived under fairly stable conditions, one of those conditions being practical assurance of a means of livelihood, and another practical equality among the members of each social class, with some sort of fixed authority over them all, if it were none other than the usurped authority of a grasping landlord. But, with the change in industry, the people were lured, driven, or dragged to the towns, where each man struggled as best he might for such wealth as he could gain; the rule of life being expressed by the phrases, "An Englishman's house is his castle," and "A man has a right to do what he will with his own." Prizes of dazzling brilliancy were to be won by those who succeeded in the game, as did such men as Josiah Wedgewood, the potter, and Titus Salt, the wool-spinner, while death in the slums and a pauper's grave were the portion of those who failed. 
Instead of organising these masses of people on any reasonable lines, the public policy of the realm merely embodied the notions of the country squires who dominated Parliament, while it held the common people at arm's length by a Poor Law which made "parish relief" a word of loathing to those for whose benefit the institution was supposed to exist. Thus, not merely left to themselves, but unfairly shut out from any leading or direction that they might have had, the people weltered. Filth diseases unknown in their country homes killed millions; steady toil in close rooms changed the very physique of the race; whole communities were debased and yielded to the overseer or employer an obedience which they would never have given to factor or landlord. Yet, unaided, in spite of Church and State and the infirmities of their own nature, the people adapted themselves to their new life, and, little by little, became the masters of the conditions which had held them in bondage.

One of the earliest devices used was the friendly society, an adaptation of the idea of the ancient guild to existing conditions. The object was insurance-to make provision in case of sickness, old age, or death. But, most of all, what was desired was to avoid the disgrace of a pauper's funeral. Thousands of societies, some small, some large, were formed with no other financial object than to provide money to bury the members. The system was abused, of course. As in the case of other friendly societies, referred to in a previous chapter, rascally treasurers stole the money entrusted to them, foolish committees attempted to give impossible benefits for half nothing, smooth rogues established clubs only to wreck them and take the proceeds, and ambitious numskulls sought to forward their own political or philanthropic fads at the expense of the society. These were the minor abuses. Many an interesting tale could be told of the struggles of the worthy people in these little clubs to keep the organisations strong and practically 
useful in spite of all the deviltry that assailed them. But we must leave all that and turn to the main evil of child-murder for insurance. This was the work not so much, if at all, of the little burial clubs as of big concerns which, whether in form or not, were, in fact, commercial enterprises carrying on the business of infant insurance for profit and whose nature will be explained as we proceed. Meantime, it may be stated, on the authority of the promoter in Parliament of a bill to regulate friendly societies, that there were in England and Wales, in I854, no less than thirty thousand friendly societies, with a membership-including people of all ages and both sexes-of over five millions. Many people were members of more than one club. A child, for instance, besides being a member of some independent concern, was likely to be enrolled in a club attached to the school he attended or the factory in which he worked. It would not be putting it too strongly to say that practically all the operatives in the big factory-towns were members of these clubs, and that the last club given up by those who grew too poor to pay even the penny or two-pence a week which it charged was the burial club.

Naturally enough, the law recognized a wide distinction between an ordinary insurance transaction by an incorporated company and a mere agreement among neighbours to assist one another in the burial of their dead. Some of the authorities on the English burial-clubs tell us that they arose in the most natural way, as thus: In a large factory or other industrial institution, on the death of a member of the family of one of the workmen, it would become common to " pass the hat" to assist the one in trouble, that he might not add to his affliction the almost greater one of going into debt to pay the expense of a funeral. After a time, this procedure would be systematised and preparations made for the inevitable. Thus it came about that in large works one man was appointed treasurer and executive, and the custom grew up of "keeping one death in 
hand," that is, collecting in advance for whosesoever funeral might come next, thus avoiding the delay and uncertainty of collection after the event. The contributions would be arranged upon a scale dictated by the circumstances and customs of the people, and the whole action would harden into a system before anybody was aware.

Nevertheless, it is clear that this system, necessary though it may have been under England's industrial conditions, beneficent though it may have been when honestly carried out, involved, almost necessarily, a flagrant disregard of a principle which England had learned at frightful expense-the principle that no man should be allowed to insure that in which he had not a clear financial interest. To avoid going over here what has already been dealt with and must be still more definitely referred to subsequently, let us merely illustrate the case. Suppose that a rich man, feeling the same need in his station that the poor man did in his of providing in advance for funeral expenses in case of a death in his family, had gone to any insurance company and had proposed to insure his child's life for the hundreds or thousands of pounds that he might think fitting to spend upon the funeral in case of the child's death, the risk would have been refused, or, if accepted, the company would not be bound to pay, the transaction being an illegal one under the statute respecting "insurable interest." Without going into too great detail, it may be stated that, at first by universal consent and afterwards by statutory enactment, it was made legal for a parent to insure his child's life for a small sum. Had it been stated on the face of the statute that the purpose was to exempt the working class from the operation of the law respecting insurable interest so far as insuring for burial expenses was concerned, that purpose would not have been any clearer to the ordinary mind. Thus, there was class legislation in this case. A privilege was conferred upon the working people. That privilege, like all privileges, and as a 
matter of course, was abused. It is not necessary to say, much less to prove, that it was abused by the working people. This is not a question of classes and individuals; it is a question of methods and systems. That the system of child life insurance was a benefit to many cannot be denied; but that it caused the death of many and became a cause of great demoralisation is susceptible of the clearest proof. This might easily have been foretold by one familiar with the principles and history of insurance. Before going into the facts of this matter as they developed in England, let me quote, very briefly, three insurance authorities as to the nature and possible results of this class of business. These quotations might be multiplied a hundred-fold from equally high sources. In Walford's Cyclopedia of Insurance, already more than once referred to, under the heading, "Children, insurance of and insurance for," it is stated:

Nearly all the industrial offices grant policies on the lives of children. The terms and conditions on which they are granted will be spoken of in our history of industrial insurance. Regarding the practice, it may find some defence in the manufacturing districts, where every parent has an interest in the prospective earnings of his child ; but it too frequently leads to the commission of the most unnatural of crimes.

The Insurance Monitor, of New York, also frequently referred to in other chapters, in its issue of February, I88I, called atten. tion to the fact that co-operative concerns had taken up the business of child life insurance, "collecting a weekly pittance of a few cents on the pledge that in the case of the child's death, the parents shall receive about as many dollars." It warns against such a system and says, "There are thousands in our great cities, steeped in degradation, and ready to traffic in their offspring as if they were horses or goats." The editor makes it clear, however, that he does not object to a "responsible institution" carrying on such a business under "strict limitations" and among "the worthy poor." 
Mr. George B. Luper, Insurance Commissioner for Pennsylvania, in his report for 1893 , said:

The practice of mutual assessment companies insuring the lives of infants is exceedingly demoralizing, and, from a moral standpoint, not very far removed from "death-bed" insurance.

Just what sort of a "recommend" this is for this kind of business, the reader will more clearly understand if he will read, as he may in a subsequent chapter, the history of " deathbed "insurance in Pennsylvania.

I do not pretend to fix the time when the suspicion first arose in the English mind that insurance was a Moloch to whom children were being sacrificed. But we find it expressed in no less'a work than the Past and Present of Thomas Carlyle, which was published in 1843 . The author tells of a crime which, as will be seen, was committed three years before, and makes it the principal point in an arraignment of the society of his time-such an arraignment as no other man who ever wrote could make. I gladly leave it to this great master of thought and of English expression to set in a proper light the awfulness of the social spectacle to which I can but point. Carlyle says:

Descend where you will into the lower class, in Town or country, by what avenue you will, by Factory Inquiries, Agricultural Inquiries, by Revenue Returns, by Mining-Labourer Committees, by opening your own eyes and looking, the same sorrowful result discloses itself: you have to admit that the working body of this rich English Nation has sunk or is fast sinking into a state, to which, all sides of it considered, there was literally never any parallel. At Stockport Assizes,-and this too has no reference to the present state of trade, being of date prior to that, - a Mother and a Father are arraigned and found guilty of poisoning three of their children, to defraud a "burial society" of some $3 l 8 s$. due on the death of each child: they are arraigned, found guilty; and the official authorities, it is whispered, hint that perhaps the case is not solitary, that perhaps you had better not probe farther into that department of 
things. This is in the autumn of $184 \mathrm{I}$; the crime itself is of the previous year or season. "Brutal savages, degraded Irish," mutters the idle reader of Newspapers; hardly lingering on this incident. Yet it is an incident worth lingering on; the depravity, savagery and degraded Irishism being never so well admitted. In the British land, a human Mother and Father, of white skin and professing the Christian religion, had done this thing; they, with their Irishism and necessity and savagery, had been driven to do it. Such instances are like the highest mountain apex emerged into view, under which lies a whole mountain region and land, not yet emerged. A human Mother and Father had said to themselves, What shall we do to escape starvation? We are deep sunk here, in our dark cellar, and help is so far.-Yes, in the Ugolino Hunger-tower stern things happen ; best-loved little Gaddo fallen dead on his Father's knees! -The Stockport Mother and Father think and hint: Our poor little starveling Tom, who cries all day for victuals, who will see only evil and not good in this world: if he were out of misery at once; he well dead, and the rest of us perhaps kept alive? It is thought, and hinted; at last it is done. And now Tom being killed, and all spent and eaten, Is it poor little starveling Jack that must go, or poor little starveling Will?What a committee of ways and means!

In starved sieged cities, in the uttermost doomed ruin of old Jerusalem fallen under the wrath of God, it was prophesied and said, "The hands of the pitiful women have sodden their own children." The stern Hebrew imagination could conceive no blacker gulf of wretchedness; that was the ultimatum of degraded, God-punished man. And we here, in modern England, exuberant with supply of all kinds, besieged by nothing if it be not by visible Enchantments, are we reaching that? . . How come these things? Wherefore are they, wherefore should they be?

The exposure of the evil by Carlyle did not end it, however, as is shown by the fact that in $185^{\circ}$ a law was passed limiting the amount to be paid by way of insurance on the death of a child, and providing that even this limited amount must be paid to the undertaker or person who conducted the funeral. This had so little effect, however, that when, in I854, a Committee of the House of Commons investigated the matter with a view to advising the House upon a bill then before it to 
amend the Friendly Societies Act, one of the principal witnesses, who spoke on behalf of a combination of clubs and societies, swore that he had not been aware of this limitation, and had never heard it mentioned by any officers or others connected with these organisations. What the suspicions in the public mind were it is easy to see in the current literature of that day. The greater part of that literature, like the greater part of all literature, was merely ephemeral, and he who would study it must take such remains of it as are to be found in great libraries. But the strongest and most searching words of it are at everybody's hand in Tennyson's poem Maud, which was published in 1855 . The opening verses of the poem, as all will remember, are a terrible denunciation of the condition of society and of those smug people who, congratulating themselves upon the fact that the land was free of war and that trade was going smoothly, forgot the evil of greed and its countless progeny of anti-social vices-in fact, those who cry, Peace, when there is no peace. After all the other horrors have been shown in review, the picture culminates in these lurid lines:

And Sleep must lie down arm'd, for the villainous centre-bits Grind on the wakeful ear in the hush of the moonless nights; While another is cheating the sick of a few last gasps, as he sits, To pestle a poisoned poison behind his crimson lights.

When a Mammonite mother kills her babe for a burial fee, And Timour-Mammon grins on a pile of children's bones, Is it peace or war? better war! loud war by land and sea, War with a thousand battles, and shaking a hundred thrones.

As already suggested, abuses of various kinds growing out of the operation of friendly societies, led to the introduction of a bill in the House of Commons in 1854 , intended to remedy the ills complained of. The promoter of the bill was Mr. Thomas H. S. Sotheron; member for North Wiltshire, a man of great public spirit and strong common-sense. One of the clauses of 
this bill, as introduced, re-enacted the provision fixing the limit of amount to be paid on the death of a child and making the sum payable to the undertaker and not to the parent or guardian, the intention being to make sure that the "burial fee" should be a burial fee in reality, and not a bribe to murder.

However much actuaries and others interested might debate the other features of the bill, the discussion by the general public was practically confined to the belief, voiced by Tennyson, that infants were slaughtered for insurance money. To say that the point was argued would be to over-dignify the discussion. On one side, there was a genteel suspicion of the "lower classes," while on the other was a feeling, indignantly expressed, that this was an attack upon the rights of the working people, and, added to that injury, the foul insult of intimating that the father-love and mother-love of the working class could be turned to infanticidal lust by the bribe of a few paltry shillings.

In the sole parliamentary discussion which took place on this bill, arising on a proposal to refer the bill to a committee to investigate the facts, these were the ruling ideas. The debate is notable because it called to their feet two of Britain's greatest men. On one side, was Viscount Palmerston, then the Home Secretary, and, as such, the mouthpiece of the Government on these questions. He declined to express his opinion on the main point agitating the public mind, the subject being too painful. But he declared that he believed legislation necessary, and said he would have been prepared to propose a bill had not one been brought before the house. He favoured the reference to a committee, but gave it to be understood that the progress of the measure would not be unnecessarily delayed. On the other side was Richard Cobden, a man to whom the lovers of peace and the believers in peaceful trade owe more than to any other Englishman who ever lived. He voiced with greater authority than any other could the feeling that the proposed 
clause affecting child life insurance was a slur upon the character of the working class, and so, a reproach to the whole nation. Quite unwarrantably, and with almost demagogic assumption, he accused Palmerston of treating the subject jocularly, and said that if the working people would kill their children for three pounds in club-money, they would destroy them to avoid the expense of maintaining them.

The bill covered many points of organisation and regulation of these friendly societies, and all these had to be investigated and considered. To what the public and the friendly societies themselves evidently regarded as the main point, - the regulation of child life insurance,-the Committee devoted several paragraphs of their report. They stated that to this subject they had devoted particular attention, and had examined four judges, two governors of prisons, two coroners, a chief of police, a chaplain of prison, a registrar of birth and death, and a solicitor who had been engaged in a prosecution for child murder. Also, letters had been produced from inspectors of factories. The evidence of these parties, one by one, is summarised in the report of the Committee, showing that in very few cases indeed had this crime of child-murder for insurance money been charged and proven, while in some cases, notably in one, on which a presentment by a grand jury and a recommendation to Parliament to legislate on the subject had been based, the accused had been acquitted. On these grounds, the Committee came to the conclusion that the instances of childmurder where the motive of the criminal had been to obtain money from a burial society " are so few as by no means to impose upon Parliament the obligation, for the sake of public morality, to legislate specially with a view to the prevention of the crime." They thought there was no ground for the suspicion that had existed in the public mind, and added, "They (the Committee) believe that suspicion to have been almost entirely founded on the few cases brought to trial, 
exaggerated by the horror with which the idea of a crime so heinous would naturally be regarded." But immediately after, they said:

A consideration was pressed upon your Committee by the judges who gave evidence before them, viz.: that it is not allowed by law to any person, rich or poor, to insure the life of another unless he has a pecuniary interest in the continuance of such life; that the insurance for burial money is at variance with this rule, and, if permitted, ought to be carefully guarded by limiting it to its avowed object, namely, the sum actually required for the child's funeral. Your Committee, assenting to this principle, have anxiously discussed the best and least objectionable mode of carrying it into effect.

As to the provision of the then existing law, limiting the amount and making it payable to the undertaker, they showed that generally in such cases there was no "undertaker" as ordinarily understood, the parent buying the funeral requisites and being considered to fill the undertaker's place-that is, no doubt, the burial society paid the money to the parent as " undertaker." The law on this point was evidently, said the Committee, "disliked by the mass of the people, who desire to have the absolute disposal of the arrangements for the burial of their children." The Committee proposed to limit the sum payable on the death of a child by one or many societies, and to make a medical certificate "from a qualified practitioner" as to cause of death necessary in such cases before the money could be paid over. With this report, the bill was sent back to the House of Commons. The statute as it passed Parliament left unchanged the then existing law as to limitation of amount, but provided for the medical certificate.

In view of the comments made upon this report by a body subsequently constituted to, as it were, do the work over again, a body containing far abler men and giving far more consideration to the subject, it is only just to point out some facts which will enable the reader to estimate fairly the weight which should 
be given to this report. On the face of it, the Committee appear to have followed the good old rule of British justice that the case shall be tried on the evidence actually produced and that the person against whom a charge is made shall be considered innocent until he is proven guilty. Had they been a jury trying a charge against an individual, or against some burial society, or even against the whole system of insurance, nothing could have been more natural or more commendable than the course they followed or the tone they adopted. Had they even been a committee to consider whether a bill should be introduced to amend the Friendly Societies Act, it might have been quite reasonable for them to demand that a crying evil should be shown to be widely existent before they recommended that the precious time of that great legislative institution which boasts itself "the mother of free parliaments" should be taken up with the matter.

But this was not a court trial, with the Committee as judge and jury. Nor was it an inquiry as to the relative importance of several measures all agitated for in the country. The measure was actually before the house; it had been commended to the favourable attention of the Committee by the Home Secretary, the man who spoke for the administration in such matters; and this matter of child-murder for burial-club money had been specifically referred to as one of the subjects on which the House desired enlightenment. It would have been quite within the competence of the Committee to report adversely to the whole measure. But, admitting, as they did, the desirability of the measure, it was their business, not merely to deal with crying evils. but to make the whole bill as reasonable, as workable as they could, and to so frame it that it should in every way promote good morals. We have already seen how the maritime law of England made "freight the mother of wages," and provided that a seaman could not demand his wages if the vessel on which he sailed was lost before reaching 
port. This was not to meet any proven evil, but merely to recognise the law of good morals which would remove from a seaman the temptation to throw his ship away and so avoid work while gaining wages.

Thus, the mere fact that no general prevalence of child-murder for burial fees had been proven was not a good plea for inaction. But, even if, generally speaking, it were a good rule of legislation to act only for the repression of known and proven and crying evils, the facts, as shown by the report of the Committee, were in favour of action and not in favour of inaction. The Committee plainly stated-it would have been hard for them to avoid stating it, even had they desired to do so-that these murders had actually taken place. The fact that such murders were few had nothing in the world to do with the case, unless the Committee were prepared to maintain that there should be no law against murder except in a country where more than a few murders were committed. Had it been shown, or even stated; yes, had it even been properly inferable from the Committee's report that the harm done to the community by any frameable law on the subject, while working good on one side, would work more than countervailing evil on the other-for instance, that, while murders would be prevented, thrift would be discouraged and demoralisation of the working class follow, -the plea for inaction might have passed.

Nothing of that kind appears. Looking at the matter broadly, as the Committee, representing the nation, should have looked at it, the argument in favour of action was very strong. Those whose lives were to be protected were the most helpless of all the people-the little children of the poor. Trades unions, petitions to Parliament, right of suffrage, even riot and rebellion, if necessary, were means by which the adult poor might make their demands known to the authorities. The children of the rich, and especially of the titled rich, were surrounded by a whole system of succession and guardianship laws. But the 
babes born in "the warrens of the poor" were the neglected of the neglected. If their parents respected their rights, well; if not, those rights were, in fact, of no value.

The crimes alleged were not so much those of violence as of neglect; and, where violence was used, it did not necessarily leave any mark nor was it necessarily attended by any struggle and outcry that would attract the attention of others. It was the right of every Englishman, then, as it is now, to get drunk. In those days it was considered honourable, if not obligatory, to get drunk whenever opportunity offered. If a drunken mother overlay her child in the night, and, a few days later, claimed and received $£ 3$ by reason of that death, could anybody say - much more, could anybody prove-that the hope of $£ 3$ and the possibility of bringing about the child's death had had any relation in the woman's mind? To protect the child of such a mother is the noblest work a legislature could do. To say that an effort to protect the offspring of such a decadent and unfortunate cast insult upon the millions of honest toilers of Great Britain, was of itself the foulest aspersion that could have been cast upon that splendid class.

But, still further, while the Committee declared that the case had not been proven and that no action was necessary, they proposed action in the form of an amendment to the law limiting the amount to be paid by the burial society on the death of any child and making a medical certificate necessary before anything at all could be legally paid. This is an admission of the whole case. All that precedes it is mere gratuitous talkthe grumbling of a man who feels that he must pay a debt and yet hates to pay it. The fact that the Committee perpetrated so much talk before making this recommendation of statutory enactment can have no effect in weakening the case upon which the recommendation is based; it only causes us to suspect the strength of mind, if not the good faith, of the members of the Committee. Fortunately, however, the British public declined 
to remain forever satisfied with the half-and-half recommendations of the report the nature of which we have just been considering. Events made further action necessary. It will be more convenient if we deal with those events and that action in another chapter. 


\section{CHAPTER XV}

\section{LIFE INSURANCE-CHILDREN-Concluded}

Changes in the Burial Clubs-"Collecting" Societies and their Methods -The Royal Commission of 1870 -Society for the Prevention of Cruelty to Children-Efforts Made to Regulate the Business and Difficulties in the Way-Practical Results.

$7 \mathrm{HE}$ next event to which I ask special attention in connection with this question of child life insurance is the appointment of a Royal Commission to investigate the whole friendly-societies question anew. This appointment was made in 1870 , thirteen years after the report dealt with in the last chapter. It was evident that the information before Parliament and the people no longer represented accurately the facts as they were. Changes had been going on steadily. In a mere summary, such as this, it is impossible to follow closely a great social movement involving not merely alterations in the condition of the people, but changes in the law, often complex and more often obscure, and the development of new methods of applying old principles of business. Many things must be assumed which some readers would rather see stated or even explained.

Let it be understood that the general tendency to division of labour and the specialisation and consolidation of business, the growth of cities, the greed of gain, and what Walt Whitman calls " the never-ending audacity of elected persons," wrought, in time, complete changes in the friendly societies of Great Britain. The conservatism of the Briton kept alive, in places, 
the old style of affairs, so that there were found, even as late as 1870 -and might still be found, I suppose-friendly societies which had existed since the suppression of the old guilds. But, as a rule, the old-fashioned club, the members of which met once a week at the public house and drank beer, and which had no object save this and the provision of a burial fund, gave place to a form of organisation having its central body in one place and its branches everywhere. Some of these great societies were social clubs of the purest type, their members being bound together by ties of sworn brotherhood, cemented by an ornate ritual and by secret grips, signs, and passwords. Cthers were trades unions, with branches covering the whole country and carrying on the business of mutual insurance up to a point.

But others were, in fact, though not in name, insurance companies doing business among the working class and the poor, and devoting, in many cases, special attention to the insurance of children on the basis of the "burial fee." On the other hand, insurance companies had reached out into this field and competed bitterly for business with these so-called friendly societies. To the ordinary mind, there was no difference between the friendly society and the insurance company carrying on this business, although the law made a sharp distinction. Anybody, however, could see the difference between the old burial society and the new "collecting" society, as the great friendly societies carrying on operations in this way were called, even though the keenest mind might not see, without close investigation, all that that difference involved. The difference is suggested by the word "collecting." In the old burial society, the members, who were all neighbours, or fellowworkers in the same factory, or who had some other bond of union, met at the tavern, drank a social mug of ale, paid their dues and transacted the business of the society. The executive work and preparation for these little meetings was in the hands of a "committee," whose services were gratis, except for a 
possible donation, perquisite, or honorarium at the annual meeting.

The very smallness of such a concern, and the proverbially uncertain character of voluntary service, made the life of such a society impossible, except where the members were bound together by some constant common interest. On the other hand, the "collecting" society was a permanent institution, a business concern, though having the same nominal form as the old society. Instead of being small, it was large; instead of being local, it covered a wide field-perhaps the whole kingdom -instead of serving voluntarily, its officers were paid, and most handsomely paid in some cases; and, instead of the members going to the society, the society, in the person of the collector, came to the members. The collector, in theory, was an officer to collect the dues of the society. But, as the president or chairman had evolved from the leader chosen by the members into the dictator and practical proprietor of the concern, so the collector had become far other than he was originally intended to be.

With the very inception of any nutual-benefit organisation, self-interest begins to appear; and we know, on the authority of Scotland's poet, that:

\section{If self the wavering balance shake}

It 's rarely right adjusted !

Following the history of these clubs, we find self-interest gaining little by little, until the "mutual benefit" scale is completely weighed down. Though the change is such a radical one, it comes about so gradually that it is impossible to say when it is actually made. But, when it is made, we find the old burial club displaced by the collecting friendly society, or, it may be, by the industrial-insurance company. This was far more than a mere change in the form of doing a part of the work of social life. It meant bringing into the work new 
people and new forces. For people to meet at the "public," spend a little-and, according to the rules, only a little-money in drink, pay their dues and transact business in which all were interested, argued in them fixedness of residence and occupation, power of organisation, and the self-denial of the forehanded-it showed them, in fact, to be, so far as the possession of the Puritan virtues and of this world's goods are concerned, a decidedly superior class of people. But, if you find a people who merely yield up a penny or twopence a week to a collector when he calls, there is nothing in that act to indicate that they are of the same class. They may be the lowest of the low. In fact, they are not unlikely to be so, for this is a very expensive way of doing business, and has no advantage, except that it saves the party the trouble of doing anything, even of thinking what he ought to do-for the collector becomes, to such a party, the whole organisation and the whole system.

Not only does this " natural selection" operate to bring into these collecting societies a low class of people, but artificial choice lends its aid also. As in almost every case, so in this, the insurance agent is paid by a commission on his receipts. With him, therefore, the object is volume of business and ease of collection. Without considering what the actual effects of this may be to-day in this class of business, let us stick to our text and learn from the documents what the effects actually were in the period and in the country of which we are now speaking. The interest of the collector was to get together a bad business-bad for the society whose employee he nominally was-rather than a good one, for the reason that goodness means selection of the good and rejection of the bad, and rejection of anything, good or bad, meant loss to the collector.

The man who would make the most in the position of collector, other things equal, would be the man with commercial instinct at the maximum and moral instinct at zero. If he knew a mother who desired to be rid of her child, he would 
seek that child's name for his " book," as they called it, for the mother would easily be persuaded to pay for a bonus of $£_{3}$ on an unnatural murder which she had in contemplation in any case. Let it be granted that such cases are rare. What then ? Every case of that kind meant an easy commission for the collector with no scruples, and no commission for the collector who had scruples. Between such a case and that of a poor but loving couple who dreaded a pauper funeal for their child, there were countless grades of people. The best of them would be aroused by their love for their children to industry, sobriety, and economy - not the mere parsimony of avoiding expenditure, but the true economy which would teach them a better way of providing for the future than the way of the collecting society. Ill-fortune might drive even the best of them to the use of this method, but a large proportion would rise wholly above the collecting society's level. This would leave the unfortunate and the unvirtuous for the collector to work amongst, and the worst collector found the easiest work and the most profit among the lowest.

It may be objected that such a man would bring undue losses upon the society, and so bring about his own dismissal. This is the same argument that we have met in considering other branches of insurance. We have seen that, however pretty it may be as an argument, it has no place in the cold world of fact. And, when we examine it closely, we find that even as an argument it is worthless. It is a good deal like the bogus "old masters" which the industrious forgers of pictures work off on millionaires from the mines or the stock exchange-designed merely for consumption by outsiders, but of no value to those who know anything about the business. It is based upon the assumption that an insurance company makes a profit by avoiding loss in individual cases. The fact is, on the contrary, that the insurance company depends for its very existence upon the fact that losses must occur in individual cases, while the 
profit comes from the average payment by the insured being sufficient to cover all losses, pay all expenses, and yield a profit besides. Let the average yield per acre be sufficient, and the farmer can afford to be careless about the quantity of seed he uses. In the early days of any business, as has already been remarked, waste is the rule; economy comes later. It would have been as unreasonable to expect the cyanide process of gold refining to precede the old pan and rocker as to expect fine selection of risks in the collecting friendly societies of Great Britain half a century ago. But there was more than this general principle involved; there was an element that, for all practical purposes, does not exist in any form of insurance which is carried on amongst business people or people who habitually look to the law for the enforcement of their rights where those rights are denied. Let us suppose that a collector whose main qualification for his business was a plentiful lack of conscience and pity had made a bargain with a "mammonite mother" which was, in effect, that she should " kill her babe for a burial fee." It did not follow that that bribe should be paid. The man who would connive at a murder would not be above taking the profit of it all to himself. This he could do by throwing the party " out of benefit," as they called it. Being, in the eyes of such a beneficiary, the whole organisation, the collector could practically prevent her from paying her dues to the society by the simple expedient of failing to call for a week or two.

This was a common fraud. I do not mean to imply that every one thus "thrown out of benefit" was a murderer of children in fact or in contemplation, or that the desire to avoid paying a bribe to murder was always the collector's object in not calling for his fees. I merely wish to point out that, in this form of insurance, it was practically possible for the collector, if he wished to do so, to connive at a murder and then take all the benefits of it himself. In the case of these benefit 
societies, these lapses were regarded as valuable - a perfect proof of the wastefulness and incompleteness of the system. poor labourer paid his dues for a year, say, without a death in his family to make necessary a call upon the society. If he then ceased paying, the society had a good profit upon a completed transaction. This advantage was so great that some of these societies depended for their very lives upon their lapses.

There was thus a plain inducement to cause members to lapse as soon as the society had got from them a maximum of benefits with a minimum of demands. In many cases, this lapsing was made a system. This is proven by the curious fact that " to lapse" became, in burial society parlance, a transitive verb - that is, not only did the members "lapse" through non-payment of dues, but officers "lapsed" the members. This being the case, there were all the conditions for a race between the officers and the member as to which could "get there" first. That is, the member had an interest in hastening a claim while he was still in good standing. Of course, it is denied broadly and emphatically that this condition of things ever hastened the death of a single baby by a single hour. But these denials would come with more force and better grace from people who had exhausted all devices to improve this vicious and cruel system than from those who profited by it and lived upon it.

The reader has already been told the results of the investigation begun in 1854 . For thirteen years, except for the introduction of an amending bill in the House of Lords, which was opposed by the societies and withdrawn, nothing in particular was done. But a good deal was said, for the frauds, misunderstandings, and quarrels arising out of the management of friendly societies kept the subject of their methods constantly before the public, now in one part of the kingdom, now in another. In 1870 , a Royal Commission was appointed, as already stated, to investigate the whole question; and investigate 
it they did, in the thorough-going manner of such bodies at their best. The Commission included very able men, among them at least two who were afterward to reach the very first rank in British statesmanship, Sir Stafford Northcote and Sir Michael Hicks-Beach. The Commission presented a report each year up to 1874 , ending its labours in that year with a report which, with appendices, fills two great volumes. It is to that report that I am indebted for most of the facts given in these chapters on child life insurance. Should any of my readers take particular interest in the subject, they will find that report a mine of information.

One branch of this report is under the title, "The bearing of burial benefits on infant mortality." This question, the commissioners say-and very truly-affects all insurance for burial purposes, whether with a friendly society or a limited liability company. They go on then to refer to the report of the House of Commons Committee of 1854 , which, as already shown, was to the effect that there was no obligation upon Parliament to act, and that no sufficient grounds existed for the general suspicion in the public mind on the subject. The Commissioners say that they cannot give so unhesitating an opinion, and that " nothing short of an inquiry coupled with compulsory powers of obtaining evidence, and with powers of indemnifying witnesses against the consequences of self-crimination, can set the question at rest." The third paragraph of the report is such a pregnant one and shows so much clearer understanding of the principles involved than is usually found amongst non-experts, that I quote it almost in full:

We would observe, indeed, at the outset, that the question is properly but one form of a much larger one, viz., that of the tendency of all insurance to the destruction, from interested motives, of the insured object. With respect to ships, the danger is one which has lately been brought into peculiar prominence. With respect to fire risks, we see every year cases tried in our law courts as to the alleged fraudulent burning of 
houses and other property. With respect to lives, the doctrine of the necessity of an insurable interest, and of the limitation of the amount to be recovered to the value of such interest, is solely founded on the recognition of this danger. The peculiarity of the friendly society system of legislation, as before observed, is that it departs from the policy of requiring such an interest in respect of the relations of husband and wife, parent and child, and thereby dispenses with one of the legal safeguards against danger referred to ; although, indeed, it introduces new safeguards, as respects the most helpless class who are exposed to it, by special provisions on the subject of infant insurance.

Burial societies or industrial insurance companies cannot, therefore, be charged in any exclusive manner with the promotion of crime, although it is clear that it is one which is far more easily practised on the infant than on the adult, and that, therefore, the incentive offered to it by the practice of insurance is multiplied in exact proportion to the infant lives assured.

It is with a feeling of relief that we read the next words:

At the same time, we are happy to say that, whatever may be the incentive, there is reason to believe that it exercises much less influence now than it did formerly.

In proof of this, the Commissioners quote the evidence of a gentleman who conducted prosecutions for the corporation of Manchester, who said, among other things:

Nearly thirty years ago there were a great many cases, . . . where it was publicly said in the town that the children had been purposely killed. . . . There was an example or two made, and then the thing ceased for a long time. . . . I think it was a regular trade a great many years ago, I do not think it is now.

But when one of the Commissioners cheerfully inferred that the witness was of opinion that enrolling children as members of burial societies did not increase the rate of infant mortality, the witness said:

I should not like to say that it did not. I think what was patent to everybody must exist still, but in much less degree. 
The next witness quoted is the coroner for Liverpool, who gave it as his opinion that infant insurance, even if it did not promote child-murder, was an incentive to the neglect of sick children by unnatural parents. Incidentally, he gives an insight into the methods by which the brutal class of parents and guardians exercised cunning to make quite nugatory the enactment requiring the medical certificate of the cause of death before the burial society, money could be paid. According to this gentleman, if a child fell ill, the parent would go to the charity dispensary, describe the symptoms and get a prescription. When death occurred, he would ask the doctor for a certificate of the cause of death, and, when the physician declared himself ignorant even of the child having ever existed, would produce the prescription. The doctor must then certify, in the rush of other business, or send the applicant to the coroner. He went on:

In that way they come to me in shoals, and, in that way, I have not the slightest doubt in the world that an immense amount of parental neglect of a most scandalous character goes on from day to day in the town of Liverpool, and I am really disposed to think that the neglect is greater than it would be on account of the prospect, at the end of the child's term of lingering, of the club-money as a sort of consolation to unnatural parents; and I believe (and I think I can be borne out by every dispensary doctor in Liverpool) that in that community many a child would never be taken to the dispensary at all, unless with a view to its interment and not to its recovery.

Another of the witnesses quoted is Dr. Cameron, editor of the North British Daily Mail, then, as now, one of the most important newspapers in Scotland, who said:

In conducting an investigation into the prevalence of baby-farming in Glasgow and in Scotland generally, I came across one case of a babyfarmer who was in the habit of adopting children at a low rate and entering them in a burial society, paying a half-penny or penny per week for them during their life, and when, at the end of six months or a year, 
they died by neglect or ill-usage, pocketing a benefit which, when it is recollected that there is no difficulty in getting persons to adopt for life any number of children for a cash payment of $£ 5$, constitutes a large addition to the bonus, and affords a very obvious temptation to infanticide direct or indirect.

In this we have another feature of the case and one that I will not dwell upon, so horrible is it. Every reader knows of the miseries of Dotheboys Hall. The unwelcome, probably shame-bringing, children of the well-to-do were herded there under the villain Squeers, given over to his absolute control, on condition only that he should keep them away from their parents. The unwelcome children of less prosperous people would be "adopted" by a baby-farmer, who insured them in burial clubs and pocketed the money when they died. Here is a trade for ghouls!

Proceeding, the Commissioners showed that the law against double insurance was a dead-letter in some localities. And why not? No law is self-enforcing. And who was there to see that this law was lived up to? All the officers who had to do with the poor-policemen, coroners, dispensary doctors, and others-had their hands more than full. If more than one amount was paid on the death of a child, it was no more the business of any officer to take up the case than it was of the Queen herself. And always there was the collector of the society interested in gathering as many pennies as possible. Say the Commissioners:

With these facts, it is impossible not to look with suspicion on the heavy infant mortality admitted to even by the best burial societies.

In one case, 1080 under ten years of age, out of 2017 insured, died. In another, forty per cent. of the deaths were those of children under two years of age, and in another fifty per cent. were under four years of age. More remarkable still are some tables made up from figures supplied by the Registrar-General. 
These tables, together with the comments of the Commissioners are given in the appendix to this work.

In pursuance of the object for which they were appointed, the Commissioners sent a circular letter to coroners and other officers throughout the United Kingdom, asking for facts and also for opinions as to the effect of the operations of burial societies upon infant mortality. Only about sixty per cent. of the officers thus addressed sent in replies. Of these, not one had any definite case to give, and only a small number expressed the opinion-but some did express it, and that strongly - that infant mortality was increased by reason of insurance. Only one case of alleged murder came before the Commission. In that case, it was alleged that the child, a girl of about eleven years, was poisoned, but the charge was not proven. The insurance was effected by a woman who said, falsely, that she was the child's mother, and who gave a false Christian name and refused to give her address. The card of membership was given her by a collector who knew nothing about her, and who admitted that the lack of address was irregular under the rules of the society. During the term of insurance, the collector entered the payments as made in advance though, in fact, they were, at times, in arrear. The child died one week after coming into benefit-there being, under these contracts, a term at the beginning during which the parties had to pay without the benefit attaching; this term passed, the child insured was said to " come into benefit." In this case, there was a conflict of testimony, "which," the Commissioners say, " nothing but a legal cross-examination could have cleared up." They leave the case where they found it " as a very suspicious one." Referring to the replies sent in by the coroners and other officers, the Commissioners say:

Having regard to the great number of officers (and many of these from important districts) who have returned no replies to our questions, the opinions of the minority afford sufficient grounds for a further inquiry 
into the subject under conditions sufficient to ensure the stringency of the investigation.

And, in this connection, they quote this from a memorandum of the Registrar-General:

The Registrar-General quite agrees with the opinion that insurance, a desirable benefit as it is when applied to men earning incomes ceasing at their death, cannot be applied to the lives of helpless infants who, instead of producing, are consuming income, without great risks of seriously impairing the salutary results obtained from parental affection left free and unbiassed.

He does not believe that insurance induces any great number of mothers to neglect more than usual, much less to destroy their children; but he fears that it has most prejudicial influence on a certain number, and it is the cause of children's deaths.

It will be seen that, on the whole, the Commissioners have no conclusive facts to present, nor do they give any final opinion on the subject. But, when a Commission of such men, after four years of investigation, are at such pains to state their suspicions, quoting the facts and opinions given by high public officials, and when those suspicions are exactly in line with suspicions long-existing in the public mind, it becomes us to take into account any further facts that may be presented, and not to brush aside what has already been shown, nor to be satisfied with any mere excuses or surface explanations. Be it remembered that there are facts known to us-the case mentioned by Carlyle and others, in which the parties were proven guilty-which were not brought before the Commission. Be it remembered also, that the Commissioners and all public officers who gave them information on this subject necessarily speak with official reserve. It is their business to deal with the facts before them. The Commissioners find, in effect, that a prima facie case has been made out, and declare that the whole matter should be investigated by a competent inquisitorial body, clothed with all the powers necessary for the performance of so difficult a task. 
But the British Parliament did not wait for the proposed investigation. Immediately on receiving the report, the Government presented a bill in the House of Commons revising and consolidating the law respecting Friendly Societies. In that bill a limit was placed on the amount to be paid on the death of a child by any or all societies in which it might be insured. This was one of the main grounds upon which those who opposed the measure based their arguments. The cry that the bill cast a slur upon the working class was worked overtime both in the country and in Parliament. The measure failed of acceptance that year. But public sentiment had been aroused on the subject, and, moreover, the interest that would have united against it had there been no provisions except those intended to protect the poor, helpless children, was weakened and divided by its own varying necessities and demands for changes in the law governing Friendly Societies. It was clear that some law on the subject must be passed, and that soon. In the following year, that is, in 1875 , practically the same bill was introduced by Sir Stafford Northcote; and, after long and searching discussion at every stage, it was passed into law.

Sir Stafford Northcote used great tact and patience in piloting the bill through. He did not allow himself to be led aside from the main purpose he had in hand by the demagogic cries raised by his opponents. His answer to the complaint that, in seeking to regulate child life insurance in these societies, he was insulting the working class by calling in question their love for their children, was complete. Among other things, he said that the bill was not necessarily directed against unnatural parents, but against baby-farmers. He showed that, in practice, children were insured for the benefit of persons other than their parents, and that, in one case, a child was insured for the benefit of its "guardian" in eight societies for a total of $£ 30$. (And this, be it remembered, was on the plea of giving the poor child "decent burial." The "decency" of 
that burial might not be wholly satisfactory, but of the certainty of it there could be but little question.) Sir Stafford declared that the investigation had proven that the danger of increasing infant mortality arising through the operation of burial societies was a real danger. The facilities afforded for thus insuring the lives of children, he said, had led to " frightful calamities." These, be it noted, were the words of a man who had spent four years in investigating this and cognate questions, assisted by colleagues almost equally able, and with a staff of secretaries and other assistants as large as could be used to advantage, and with all the power at his back which the commission of the Sovereign could give. Nor was he a man who had gained information which he could use irresponsibly. He was Chancellor of the Exchequer, holding thus almost the highest position in the Government; he was second man in the House of Commons, and was looking forward to the time-it came within less than two years through his great leader, Disraeli, becoming Earl of Beaconsfield and taking his place in the House of Lords-when he would be the leader of that great representative body. He was the man who, as introducer of the bill, was mainly responsible, not merely for making a good bill, but for making a bill which should avoid trouble and win credit for the Government among the masses who were to be its judges at the forthcoming general election. The utterances of such a man in such a position are entitled to respect; we know that they will be based upon absolute information and will be characterised by that reserve which the circumstances impose upon him. Therefore, when he spoke of "frightful calamities," we may be sure that that expression is not too strong to fit the case. The bill, as I have said, was passed. One of its provisions was that the total sum to be paid at the death of a child should not exceed $£ 6$ for a child under five years of age, and $\ell_{\text {Io }}$ for a child under ten. Another was that the burial benefits in the case of children were to be 
paid only to the parent or the personal representative of the parent.

Assuming that these are matters to be regulated by statute, and assuming that the amounts fixed were such as would give the dead child decent burial and leave nothing over, and that payment to the parent was a guarantee that they would be used only to pay for the burial, the bill was a perfect one.

Fourteen or fifteen years passed, years of tremendous activity in the life of the British people. Commerce extended, trades unions flourished, cities increased in population with great rapidity. Many of the rich grew richer; and many of the poor, if they did not grow absolutely poorer, did not increase in wealth in proportion to the more fortunate, and.so were relatively worse off than ever. The differentiation of trades went on. Child life insurance by collecting societies was proven to be an excellent means of making money, and, like other branches of insurance, it was greatly extended. During this time, the philanthropic element was not idle. Among other unfortunate classes who had attracted attention and whose interests, it was thought, needed protection, was that composed of the children of parents who were unable or unwilling to treat them fairly. A Society for the Prevention of Cruelty to Children was formed in 1884, with the great and good Queen Victoria as its patron, and including among its members some of the most truly noble in the land. Those who undertook to carry on the work of the society found their efforts blocked at every turn by the deplorable state of the law. Generally speaking, the rule, "A man may do what he will with his own," seemed to be interpreted as applying to children as to personal property. If a child had rights as a British subject, the acknowledgment of them was rather academic than practical in its character. But not only was the law not good, it was found in some respects to be actually and actively vicious-worse than no law at all. Among the enactments 
most loudly complained of by the philanthropists of the Society for the Prevention of Cruelty to Children was that permitting cliild life insurance. Again the public were agitated over reports of outrages growing out of this system. In I889, a bill was introduced in the House of Lords to forbid the insurance of children; but it was not pressed until the following year, when it was referred to a select Committee of the House for investigation. The Committee met and took a little evidence, but postponed the rest. The Committee was re-appointed in the following session of Parliament; but its labours seem to have come to an abrupt end through the death of its Chairman, the Archbishop of York, who had introduced the bill. The result of the inquiry was a declaration by the Committee that it was not expedient to proceed further with the measure.

Just why this conclusion was reached is not clear from the testimony submitted. It may have been that the members thought that previous efforts to perfect the law on this subject. had not resulted in unmixed good, and that such improvement had taken place in the condition of affairs, as a result of the direct operation of public sentiment, that inaction seemed safer than interference which might prove merely meddlesome. The evidence, however, was enough to turn one sick. It was shown that infantile insurance had been pushed not merely among the thrifty and provident, but among the shiftless, the vicious - that frightful element which our system of society seems to produce as merely waste human material. It was. shown that in abodes where there were absolutely none of the characteristics of a home, the children were insured. More than one parish officer swore that the most utterly depraved people of the slums were reached by the insurance canvasser, and that in these haunts of everything which our society declares anti-social, children were insured as soon as they were born. Women in whom poverty, drunkenness, and brutal de- . bauchery had worked what seemed a complete transformation, 
depriving them of all mother love and every vestige of even human affection, were touted to buy, for a penny a week, the guarantee of money to engage in a drunken orgie upon the death of their unfortunate children. But even this was not the worst. There may be in the mother some sort of pride in her child, if not love of it. "An ill-favoured thing, sir, but mine own," says Touchstone of poor Audrey. Even Nero, who seems to have had no other virtue, seems to have had pride in that which appertained to himself. The law of 1875 , restricting the payment of insurance on the lives of children to the parent or the parent's representative, had at least this lastremaining poor virtue of pride as its foundation. But it was shown that this law was shamelessly evaded, and that the unspeakable trade partnership between the insurance touter and the baby-farmer was still in active existence.

Let it be stated plainly, lest there should be any possible chance of misunderstanding, that the insurance man who admits that the issuing of policies or certificates to this shiftless class of people is to be commended, has yet to learn not merely the first principle of his business, but the first element of respect for it. Leave aside morality, social demands, and even common decency, and consider the case as a cold matter of reason. If insurance has any virtue-and it has much virtue, in spite of what some of its so-called friends say of it, and in spite of their efforts to excuse villainy because its phylacteries bear the insurance name-it is as the guardian of industry, the bulwark of thrift, the perfection of voluntary social organisation for economic purposes. But what, in the name of all that is reasonable, have these things to do with the class indicated? What did they know of industry? It was to them but a hateful, though necessary road which led to money and so to drink, a joy which might often be attained more readily by thievery or mendicancy. What was thrift, according to their way of looking at it, but a careful hoarding of liquor, or 
the price of liquor, so that the provident person might be drunk as often, as completely, and as long as possible? What did they know of social life, except that it was wise to keep out of the clutches of the police, and that in company one could be more joyfully intoxicated than when alone? I am not judging these people, or saying that they are worse than others, for I realise the force of Ruskin's suggestion that they may be far better than so-called better people who have benefited by the system of society of which they, in many cases, are the victims. Nor do I forget that, as our intelligence increases, we sometimes find that what we have regarded as the waste of a factory turns out to be more valuable than the main product, and so may it be, some day, of this human waste. I am only pointing out that insurance is a system depending for its very life upon qualities the exact reverse of those we find most prominent among these people, and that, if there are reasons why we should not give children fire-arms to play with or encourage the cigarette habit in the powder factories of the country, those same reasons, properly brought out, should cause us to check any influence which tends to spread child life insurance among the lowest inhabitants of the slums. Had the concerns that insured the lives of children gained a proper sense of their own position, they would have demanded the enactment of such a law-or, if that was inadvisable, the establishment of such a usage-as would confine their business to its proper sphere among people of thrift. And had the people of Great Britain understood the case, being the lovers of freedom and fair-play that they are, they would have killed, by sudden and complete neglect, any concern that had made itself a party to this horrible traffic with "mammonite mothers" or ghoulish babyfarmers;-aye, even any that was so lacking in respect for decency and public opinion that it did not take good care to clear its skirts of any such imputation.

Though the bill introduced in the House of Lords, designed 
especially for the protection of children, was not passed, a measure, introduced in the House of Commons, to amend the law relating to Friendly Societies, was passed in 1889 . It was proposed that this measure should contain provisions for the protection of children, but as actually passed, those provisions do not appear. As usual, the bill, after the principle of it had been affirmed, was sent to a special Committee, by whom evidence on the subject was taken. That evidence was enough to convince anyone that the "frightful calamities," of which Sir Stafford Northcote had spoken years before, were by no means wholly prevented by the existing law. The Committee was evidently hard to convince, being impressed by the magnitude of the business, and the danger to the interests of the poor and very poor of interfering with such opportunities for thrift as were afforded them. In stating their conclusions, the Committee went to the very extreme of reserve, so far as this question was concerned, as thus:

Your Committee are convinced that the allegations of culpable and even wilful neglect or violence resulting in the death of children have been, in some cases, well founded; and that the object of such neglect and violence has not been disconnected with the sums payable on the death of the children. It should be added that, from the nature of the case, it is almost impossible to obtain direct and inculpating evidence of criminality of this character, which is chiefly committed by a single individual in the privacy of home.

Proceeding, the Committee find that there are inconsistencies and imperfections in the law, as to the amount allowed to be insured, and as to the checks, by death certificate and so on, upon mere gambling insurances on the lives of children. They discuss various suggestions made to them-one, the total abolition of this system of infantile insurance; another, a provision that the money payable at the death of a child should be paid only to the undertaker; another, that all burials should be 
under state auspices, - and so on. They do not favour these ideas, but reach the conclusion that there should be a slight reduction in the sums payable on the death of children, an extension of the limit of age under the law, and a straight prohibition of insurance of the lives of children for more than certain fixed sums. (The then existing law allowed unlimited insurance, but forbade the payment of more than a fixed total sum at death, no matter in how many societies or for what total the child's life might have been insured. In other words, no matter how great a bribe the baby-farmer might think he was to get for the murder of a child, the law declared that the bribe should not be paid beyond a certain amount.) The Committee recommend also changes affecting the system of registering deaths so as to give information to the public as to whether insurance existed on the life of the deceased-an application of the British idea of publicity as a cure for public ills. Other general changes suggested in the law would have the effect of toning up the whole system of industrial insurance, increasing the responsibility of officers of companies and societies, and making obligatory greater publicity in the management of their affairs.

The bill to amend the Friendly Societies Act was passed in that year (1889) but I do not find that the recommendations of the Committee, affecting child life insurance, such as they were, were carried into effect by that enactment. From the current literature of the time, it would seem that the real or supposed intemperance of language of some of the supporters of a more stringent law aroused a feeling of irritation in the public mind which enabled those whose interests were thought to be bound up with this system to draw attention away from the main question.

In the two investigations to which reference has just been made, one by a Committee of the House of Lords and one by a Committee of the House of Commons, of course, the evidence 
was not all on one side. The statistician would hardly miss such chances as these. He was on hand with figures which simply must have made the poor legislators gasp. He was able to show, for instance, that, on the whole, the duration of child life among the insured was greater than among the uninsured. This was supposed to show a balance in favour of the business, though it was not put exactly in this way. Just by what right the Friendly Society managers intervened to kill off some babies so as to prolong the lives of others was not shown. And just why, if this was to be a matter of mere mathematics, a mere making of averages, some people were in jail for helping to pull down the average by killing off young children for insurance money, did not clearly appear. The fact is, of course, that in this case again, a supposedly practical committee, nominally convened for a practical purpose, was imposed upon, through the ignorance of its members, by mere figure jugglers, whose play had nothing in the world to do with the matter under consideration. The actuary finds that the risks for which he must provide in striking a rate of insurance for given purposes include that of murder for insurance money. He does not immediately leave his arithmometer to rush out and cry aloud to the people to unite and prevent the continuance of this form of subornation of murder. By no means. He adds this slight element of risk to the others and proceeds calmly with his work. $\mathrm{He}$ is a practical man. But he is not the only practical man, nor are the figures with which he deals the only possible representation of the facts. That slight trace of risk-it may be so small that the very actuary is in doubt whether it should not be lumped with others under " miscellaneous" or " personal equation," - means, in the practical affairs of practical life that a dozen, or a score, or a hundred, or a thousand babies must die of starvation, cruelty, neglect, poison, or violence every year or every ten years. To make such a thing a matter of averages we might fairly 
denounce as outrageous and insulting to humanity. But it is sufficient to say that our whole system of society is based upon the assumption that the one supreme fact of the world is human life, the one great duty of government to protect the life of every individual; and that to set public convenience or private advantage forth as an offset to human life is illogical.

The fact that babies were actually killed for life insurance money was admitted. In view of the fact that, notwithstanding the difficulties of proof, some of the criminals had actually been convicted, denial would have been rather absurd. And it would have been almost as absurd to say that every person actually guilty of this crime had been hunted down and convicted. These crimes, it cannot be too often said, were committed in the uttermost black, slimy recesses of that practically unknown world, the slums of great cities. The unfortunate child, the predestined victims of one of these horrible murders, was too young to suspect its impending fate, and too weak to take any steps to avert it should any miracle enlighten it. There was nobody to interfere on its behalf, for such as was one parent so was the other-drunken, dissolute, fearing not God neither regarding man. And how was murder to be suspected, much less proven? If the child was starved, were not all in the same condition? If the child was abused, was any other weak person there much better off? And, when death came, how could judge or jury know that that death was due to greed of gain and not to mere poverty, with all that the word often implies? How could any human record set down the facts, much less make known the motives which had made those facts? The circumstances justify us in suspecting everything. The Committees of British legislators seem to have suspected the philanthropists, against whom there was no charge except of meddlesomeness and notoriety-seeking, and to have demanded the most complete and overwhelming proof of every jot and tittle of the charge against the insurance 
companies, which was - and it was proven and generally admitted - that one effect of their operation, was to suborn wretches to murder helpless children. The legislators, being free men and responsible men, had a right to their opinion and were bound to express it fairly.

Once more, also, it was argued that if these murders for insurance money were nearly so numerous as alleged, the losses to the societies would be so great that they could not continue in business. That argument has been dealt with but a few pages back. But the Committees, probably, had never heard it before. One can imagine with what interest and consideration it was received by them; and one can imagine, also, the winks exchanged by the knowing cards who used it, when they met in their offices.

Another argument-by far the most respectable of the lotwas that to change the law would be to run the risk of discouraging thrift on the part of some worthy people. This may have been a good reason for not following any line of action then suggested. But it was hardly a good reason to urge upon the legislature of a free country for taking no action at all. That may, possibly, be a matter of taste, however, and, as such, not open to argument.

Again, the representatives of the several societies and companies tried to make it appear that, even if there were any truth in the allegations of murder for insurance money, they severally and their several institutions had nothing to do with it. This argument showed a commendable respect for public opinion. Each concern, however, would have shown a higher regard for the business in which it was engaged, if it had insisted, in its own interest, as a non-murder-suborning organisation, that every device of legislation should be exhausted to drive out of the business every man and every concern that could be shown to have been guilty, even by neglect, of assisting in any way in these fearful crimes. For such desire as 
they showed to keep themselves right both in action and before public opinion, these parties are to be commended; for such success as they achieved, they are to be congratulated.

Since these investigations and the amendment of the law referred to, this question has come up for further public discussion from time to time. The labours of the Society for the Prevention of Cruelty to Children have, from time to time, unearthed some shocking cases. There seems reason to believe, however, that great changes have taken place in the methods of conducting the business, and that these, combined with a steady, intelligent enforcement of the existing law have made further troubling of the legislature unnecessary. In fact, the direct operation of enlightened public sentiment on this subject seems to be sufficient to maintain honesty and decency in this business. One or more attempts have been made since I 889 to have amendments made in the law on the line of the recommendations of the House of Commons Committee, but, I believe, unsuccessfully. Given a sufficiently active public opinion to hold in check the parties who might otherwise seek to profit by the death of insured children, the present law, no doubt, will be sufficient for all practical purposes.

It will be observed that in what has been said on this most repulsive subject, I have sedulously confined myself, for my facts, to public documents. Those who are acquainted with those documents will know that $I$ have been conservative in my choice of facts and in the use I have made of them. They will see that $I$ have avoided giving details of special cases. For this there is the double reason that my readers would not thank me for harrowing their feelings on a question the interest in which is mainly historic, and that details might tend to arouse indignation which would becloud our judgment. But, if the reader has any desire to contemplate human depravity at its worst, he will find it pictured in the doings of those monsters who have taken insurance money as the price of the lives 
of helpless children. Of all the outrages upon the body social which insurance has committed, this is the worst and blackest. And it stands as a blot upon the fair name of insurance as an institution that many of those engaged in it, instead of helping on the good work of putting down the ghouls whom their operations called into activity, either took no part in that work, or took part on the evil side. 


\section{CHAPTER XVI}

\section{COMPANY FRAUDS}

Evils Arising from Desire of the Trustee to Possess the Insurance Fund - Promoting Bubble Companies-The Case of the West MiddlesexDaring and Skill of the Promoters-Exposure and Ruin of the Company-Bogus Companies a Constant Drain upon the Public.

UITHERTO, except in those chapters in which the history

of insurance generally is dealt with, we have considered only those frauds and evils which arise from a desire on the part of the beneficiary of the insurance to realise. We now come to another class of evils-those arising from a desire on the part of the custodian of the insurance fund to appropriate that fund to his own use. This form of wrong-doing is different from the other in that it means only a money loss, and no thought of sickening violence obtrudes-except that, when, as in the case of the weak burial societies of which we have just been speaking, it becomes a question with the beneficiary whether he will await the probable death of the concern and the loss of all that he has paid in or bring about an immediate loss and so have a better chance to realise, experience shows that he does not always choose the former. That is to say, intended fraud on the part of the insurer may be anticipated by arson, barratry, murder, or other crime on the part of the insured. But, even without this, the fraud of the insurer is a particularly cruel and demoralising wrong, the insurance fund, as already suggested, being one of peculiar sacredness. But it has been shown, on the other hand, that the very nature of the insurance contract offers special opportunities and temptations 
for this class of fraud. It does not follow that insurance must, in any case lead to these crimes; but it does follow that if we do not guard this weak point, insurance will bring upon us wholly unnecessary ills. We do not condemn banks because men are placed in positions of temptation through being called upon to handle millions in money, their salaries being but pittances in comparison. But we do insist that bankers shall pay their employees fair living wages, and that they shall provide such a system of checks that the certainty of speedy detection shall warn the weak among those employees not to give way for a moment. It is when these precautions are not observed that banks become snares to men who, under fair conditions would live and die honest. In the same way, it is the business of the public to demand that insurance, from which the people derive such benefits, shall not be left without safeguards which will make it difficult or impossible for the custodian of the insurance fund to use that fund for his own benefit.

This, whatever may be said of other evils with which we have been dealing, is not a question which can be finally settled by any statute law. Insurance is a living, growing thing; and it assumes so many shapes and makes itself felt in so many ways, that no fixed, lifeless form of statute law can guard it at every point. This is illustrated by the facts given in this and succeeding chapters. The facts show that, in different communities and under varying circumstances, what are practically inventions are made in the world of insurance, making it necessary for regulative machinery to be extended and applied to these new applications of the old idea, in order to prevent them working out to the injury of society, as they have many times already. To neglect this would be no more reasonable than to adopt for general use a new form of power machine without any device equivalent to the governor and safety-valve of the steam engine. To show what dangers arise 
from leaving unchecked the greed of the custodian of the insurance fund is the purpose of the remaining portion of the historical review comprised in this work. In this branch, as in the other, it is clearly impossible to cover the whole field, even . in epitome. Frauds of this kind have been going on ever since insurance began, and they have assumed every form imaginable. They are going on to-day, and a mere enumeration of those engaged in them and the methods they follow, would require far more space than can possibly be afforded for the whole question. All that can be done is to deal with some of the more remarkable outbreaks of fraud and to point out some very general and very obvious principles. It seems worth while to give a special chapter to each of two great outbreaks in America, the "graveyard" or "deathbed" craze, and the "bond-investment" mania, both of which have been marked by the organisation of fraudulent concerns to an extent which involved social demoralisation within a large circle. These and other lesser cycles of bogus-company promoting in the United States had their prefigurement in the great Bubble Period in England, when the lottery insurances, the "little goes," and other follies and villainies which are outlined in another chapter held sway.

But it must not be supposed that England learned wisdom on this subject from one great lesson, costly though it may have been. It would be as reasonable to say that there had never been an era of crazy speculation since the collapse of the South Sea Bubble. We have already passed over, with a mere hint of its extent and importance, the great friendly-societies movement in England, and the robberies of the poor that were carried on in the name of brotherhood and philanthropy by sharpers who used these societies for their own selfish ends. But the evil, after all, was only a temporary one. The wound was deep and jagged and poisoned; but society recovered. Though many individuals were ruined, there is now almost no 
sign of what was done, except as we go back to the reports of investigations by parliamentary committees and other musty records, which, however, we can afford to neglect. That such evils still exist, there can be no doubt; that there is danger that they may recur in violent form, can hardly be questioned. But the danger grows more remote; for social changes, as already shown, have made insurance a separate business and not a business to be entered upon co-operatively, except in communities where neighbour-knowledge and common interest, while affording a sound basis for co-operation, afford also protection against the wiles and schemes of sharpers. It is well, therefore, merely to make note of this phase of evil, but to save our space for that which, while no truer historically, is of more practical value.

For a hundred and fifty years, the making of bogus insurance offices was a favourite form of fraud in England-not always equally popular, but recrudescing at intervals as the public memory of the last great crash became dim, or as some new scheme for gulling the simple was made possible by changing circumstances and practicable by the inventive genius of some candidate for easy, but not too honest, affluence. Passing over others, however, we come to that era of which the reader of popular literature catches glimpses in several novels of a little more than half a century ago. One of these is Dickens's Martin Chuzzlewit, which was published in 1842. Dickens, as we all know was-at the time of the publication of this book, at any rate-a writer with a purpose. In that series of books beginning with Nicholas Nickleby and its exposure of the horrors of the Yorkshire schools, - for which, as the Encyclopadia Britannica says, the author made investigations on the spot like a government commissioner, - and including Little Dorrit and the system of imprisonment for debt, Our Mutual Friend and the evils of official red tape, Bleak House and the canker of the law's delays, and others, Dickens devoted part of 
one book to the evils of wild insurance speculation. This book was written when the author was fresh from the triumphs of his first American tour; and it shows his genius at its strongest, if not at its broadest or highest. The lampooning of the American people in which he indulged-notwithstanding that their most idolatrous appreciation of him and their excessive kindness to him would have blinded to their faults and peculiarities one less completely self-centred or less alive to oddities of human character-distracted attention from the purpose of the book, so far as the exposure of the evils of fraudulent insurance was concerned. On the other side, the brilliancy of the character-painting, the readiness with which this great wizard called spirits from the vasty deep of his creative imagination, and crowded this one book with people we can never forget, made the purpose of the book less clear to the eyes of the ordinary reader. When we think of Tom and Ruth Pinch; of Pecksniff and his daughters; of Mark Tapley and the hostess of the Blue Dragon; of Bailey and Poll Sweedlepipe; of Sairey Gamp, with her familiar spirit, Mrs. 'Arris, and Betsey Prigg; of Hannibal Chollop and Jefferson Brick; of Tigg Montague and Jonas Chuzzlewit; of all the people at the American levees and all the people in Todgers's boarding house; and of dozens and dozens of others who come and go throughout the book, we can see why readers are blinded to the absurdity of its plot -if it can be called a plot-as well as to the great purpose the author seems to have had in writing it. But let the reader go over this great book again, and note how the author, like a true seer, shows the enlargement of the circle of demoralisation of which the robbery of the foolish through bogus insurance is the beginning - how the temptation breeds vice, how vice gives birth to crime, and both bring ruin to guilty and innocent alike.

Another novel dealing with this subject is Thackeray's The Great Hoggarty Diamond. This work first appeared in monthly parts about 1839 , before the great author had more than begun 
to develop the powers which at their highest gave to the world Vanity Fair and The Virginians. In the account of the West Diddlesex Fire and Life Insurance Company, a close view is given of the working of a bogus insurance concern. We see in correct proportion many details which Dickens was not able to give. But the light which the showman turns upon the panorama which he unrolls for us is by no means so bright as that we have from the more mature genius of Dickens. In Samuel Titmarsh, however, we have one who was himself one of the most complete victims of these frauds, and an unsuspecting means of leading others to ruin. The scoundrel Brough, with his airs of piety and his cool, unscrupulous daring, is one of the most truly limned characters in fiction. Thackeray, at this time, had but just cast aside the painter's brush, convinced that it would never win him fame, and had taken up the pen instead. His grasp of it was by no means firm. While the drawing of this great character, Brough, is accurate, there is an absence of that sweep and firmness which indicate the trained hand and eye of the master. A reading of The Great Hoggarty Diamond will convey to the reader a much truer idea of the modus operandi of these frauds than will a reading of Martin Chuzzlezvit, but Dickens more truly indicates the effect of them upon society. The choice of name made by Thackeray, "West Diddlesex," as will presently be seen, indicates a close study by the author of a famous case of that time. In Martin Chuzzlewit, we see that the author laid out ground which, afterwards, he did not cover or use in any way. One of the most striking cases of this kind is the hint given by Jonas Chuzzlewit that he intends to insure his wife's life. In this, the author was evidently preparing for one particular form of villainy for this most hateful creation of his. But poor Merry survives her husband, and there is no suggestion that her murder for insurance money was further contemplated. It is not unlikely that the use of this idea by other novelists 
diverted Dickens from a course which might mar his reputation for originality.

It would be a mistake for the reader to suppose that the exposure of the doings of Brough and Tigg Montague were mere embellishments of works of fiction. Dickens and Thackeray never more squarely attacked a crying evil or timed their strokes better; for at this time the commercial atmosphere was heavy with the stench of dead and rotten insurance concerns. Reading the popular histories, one gains the impression that all Englishmen were in a condition of poverty for years before the repeal of the Corn Laws in 1846 . It is true that this was a period of fearful distress. It was the time of that almost unthinkable crime in Stockport of which Carlyle tells us in his Past and Present, and which has already been referred to. Chartism was rampant, having the support of thousands who did not understand it, but whose sympathy with the poor made them ready for any change. The workhouses were full. Social discontent was everywhere. Yet, while there was this terrible suffering among the masses, there were large classes in Eingland who were well-off. The Corn Laws were for the benefit of the landlords, and to the benefit of the landlords they inured. All who were connected with or dependent upon the landlords prospered, - - the clergy, the army officers, the servant class, the tradesmen who ministered to the rich. Many were the hoards, little and big, in England. On the other hand, the depressed state of general trade and the disturbed state of the country - for Feargus O'Connor and his Chartists were: threatening to establish a republic, and continued and increased their threats even after the well-loved young Princess: Victoria had taken up the sceptre-made it very difficult to find good investments. The distress among the rich, which Punch afterward burlesquingly voiced through the clergyman who tells the tramp how happy is his lot that he knows nothing of the worry of finding an investment that combines safety with 
anything like a decent rate of interest, was an everyday subject of complaint on the part of the well-to-do. There could be no more favourable condition for schemers who desired to sell handsomely engraved life-insurance policies or annuity certificates. The crop being ready, the labourers entered the field; and, by the time Thackeray and Dickens took up the subject, many a poor fool of a parson or half-pay officer had had a course in practical finance at the expense of all his little fortune. For a time, it seemed that the public never would get enough of this folly. As the gudgeons grew wary of one bait, another was fashioned. But always the true genius among the swindlers was found to be he who affected the greatest prosperity, and who seemed to hold himself as just a shade more respectable than the class whose money he coveted. Here it is as Dickens describes it:

The Anglo-Bengalee Disinterested Loan and Life Assurance Company started into existence one morning, not an Infant Institution, but a Grown-up Company running along at a great pace, and doing business right and left: with a "branch" in a first floor over a tailor's at the West-end of the town, and main offices in a new street in the City, comprising the upper part of a spacious house, resplendent in stucco and plate-glass, with wire blinds in the windows, and "Anglo-Bengalee" worked into the pattern of every one of them. On the door-post was painted again in large letters, "Offices of the Anglo-Bengalee Disinterested Loan and Life Assurance Company," and on the door was a large brass plate with the same inscription: always kept bright, as courting inquiry ; staring the City out of countenance after office hours on working days and all day long on Sundays, and looking bolder than the Bank. Within, the offices were newly plastered, newly painted, newly papered, newly countered, newly floor-clothed, newly tabled, newly chaired, newly fitted-up in every way, with goods that were substantial and expensive, and designed (like the company) to last. Business! Look at the green ledgers with red backs, like strong cricket-balls beaten flat; the court-guides, directories, day-books, almanacks, letter-boxes, weighing-machines for letters, rows of fire-buckets for dashing out a conflagration in its first spark, and saving the immense wealth in notes 


\section{Company Frauds}

and bonds belonging to the company; look at the iron safes, the clock, the office seal-in its capacious self, security for anything. Solidity! Look at the massive blocks of marble in the chimney-pieces, and the gorgeous parapet on the top of the house! Publicity! Why, "AngloBengalee Disinterested Loan and Life Assurance Company" is painted on the very coal-scuttles. It is repeated at every turn until the eyes are dazzled with it, and the head is giddy. It is engraved upon the top of all the letter paper, and it makes a scroll-work round the seal, and it shines out of the porter's buttons, and it is repeated twenty times in every circular and public notice wherein one David Crimple, Esquire, Secretary and resident Director, takes the liberty of inviting your attention to the accompanying statement of the advantages offered by the Anglo-Bengalee Disinterested Loan and Life Assurance Company, and fully proves to you that any connection on your part with that establishment must result in a perpetual Christmas Box and constantly increasing Bonus to yourself, and that nobody can run any risk by the transaction except the office, which, in its great liberality, is pretty sure to lose. And this, David Crimple, Esquire, submits to you (and the odds are heavy you believe him), is the best guarantee that can reasonably be suggested by the Board of Management for its permanence and stability.

And here is what the head of this precious concern thinks of it all, as shown in a conversation with Jonas Chuzzlewit, whom he seeks to entice into his web by offering to share with him the profits of the fraud:

"Do you find me at all changed since that time?" he asked. "Speak plainly."

Jonas looked hard at his waistcoat and jewels; and said, "Rather, ecod!"

"Was I at all seedy in those days ?" asked Montague.

"Precious seedy," said Jonas.

Mr. Montague pointed down into the street, where Bailey and the cab were in attendance.

"Neat: perhaps dashing. Do you know whose it is?"

"No."

"Mine. Do you like this room ?"

"It must have cost a lot of money," said Jonas. 
"You're right. Mine too. Why don't you"-he whispered this and nudged him in the side with his elbow-“"why don't you take premiums, instead of paying 'em? That's what a man like you should do. Join us!"

Jonas stared at him in amazement.

"Is that a crowded street?" asked Montague, calling his attention to the multitude without.

“Very," said Jonas, only glancing at it, and immediately afterwards looking at him again.

"There are printed calculations," said his companion, "which will tell you pretty nearly how many |people will pass up and down that thoroughfare in the course of a day. I can tell you how many of 'em will come in here, merely because they find this office here, knowing no more about it than they do of the Pyramids. Ha, ha! Join us. You shall come in cheap."

Jonas looked at him harder and harder.

"I can tell you," said Tigg in his ear, "how many of 'em will buy annuities, effect insurances, bring us their money in a hundred shapes and ways, force it upon us, trust us as if we were the Mint; yet know no more about us than you do of that crossing-sweeper at the corner. Not so much. Ha, ha!"

This is not the product of the novelist's brain, so far as the relations between such companies and the public were concerned; it was cold, hard fact, fact which could be found, line for line and word for word in business periodicals, notably the ever-commendable Post Magazine, and still more precisely and coldly in the reports of parliamentary committees. The argument of Herbert Spencer that people will take a man for what he pretends to be, and will even give their money into his keeping because he has a sign, "Banker," over his door, this being almost in so many words the statement of the debonair, but ill-fated Tigg Montague, was surely never better exemplified than in the case of these bubble companies.

The earliest of the great swindles of the period with which we are now dealing, was that upon which Thackeray evidently based his story. This was the Independent and West Middlesex Fire and Life Insurance Company, commonly referred to in 


\section{Company Frauds}

the literature of the time as the "West Middlesex." With the change of a letter, this was exactly the name chosen by Thackeray-he called it the "West Diddlesex." This concern was organised in 1830 by one Knowles, who at the time was over sixty years of age, and who, one would have thought, from the accounts of him, had none of the qualifications of a great swindler. Not only was he an old man, but his record was against him. He was ignorant; he was a tradesman-a shoemaker-and had been under the censure of the law for smuggling, and had no money with which to make a start. But the "psychological moment" seems to have come for him with the year I83o and his acquaintance with one William Hole, at one time a footman, later a tallow-chandler, and, still later, a bankrupt. These two, thus so well met, joined their resources to get out a prospectus and rent and furnish an office. At that time, there was practically no more difficulty about a man going into the insurance business than into the grocery business. Knowles and Hole first " worked" to perfection an idea which they borrowed from others. This was the use in their prospectuses, of surnames great in the world of finance, for their directorate. Price, Perkins, Lloyd, and others-names to conjure with in those days-appeared in the list of incorporators and directors, but, of course, with such Christian names and initials as to enable the promoters to avoid prosecution for the unauthorised use of names of well-known men. As a matter of fact, the directorate was filled up with a crew reminding us of the "dance of clowns" in the Midsummer Night's Dream. One director was a boy of sixteen, who, when not engaged in the onerous work of "directing," swept the floor and ran errands. Another was one William Wilson, whose ambition had been to act as porter for the office, but who was engaged to "double," as theatrical people have it, in the directorate. One of the most severely respectable directors was one Taylor, a journeyman bell-hanger, and brother-in-law 
of Hole. This man arranged with the master bell-hanger for whom he laboured to be allowed, on board-days, to absent himself from his work. These worthies were ordered to dress themselves in their Sunday best and to wear rings and other signs of gentility when attending board meetings-a fine of half-a-crown against him who dared to appear otherwise than properly attired.

The new concern had to face the competition, not only of the reputable offices, but of all the offices that were no more reputable and no more scrupulous than itself. The West Middlesex fakirs proceeded with magnificent confidence in the gullibility of the public. If they could not persuade the most cautious people that they were solvent, they could arouse the hopes of the avaricious by promises, and they could share with others the spoil of those who were robbed. In pursuance of this policy, they offered insurance at lower rates than others had dared to propose, and the rates for annuities were simply dazzling. Everybody who could bring in business of any kind was given a fat commission upon that business, and regular agents, instead of being paid the five per cent. offered by other companies, were paid twenty-five per cent. And these splendid commissions were actually paid in hand. The avaricious agents all wished to represent this splendid and generous concern; and the conspirators, in accordance with their regular policy, chose the most respectable men they could find in every place.

Knowles and his partner were consummate generals in thisthey never feared their opportunities. If money came into their hands, they used it to the best purposes. In opening a bank account, they chose the Bank of England-and advertised the fact. As soon as there was any opportunity to do so, they not only established a fine head office, in a most respectable neighbourhood in the City, but opened branches in the larger towns throughout the United Kingdom. They grew with their 
business, showing an ability-which, in men of their condition and training, was little short of genius-in adapting themselves to their surroundings. There was nothing second-class about these men. Having set out to play upon the credulity of the almost unthinkably foolish upper middle class, they knew no such thing as hesitation or indecision. They took, with becoming condescension, the small savings of the poorer people with whom they dealt. But, as time went on, and a richer class began to entrust the concern with their money, Knowles and his partner were found to be just a little richer, and just a little more impressive, if not quite so high-bred, in their manner than those who sought to do business with them. They did not arouse suspicion by acting the thief in any way, but spent openly and ostentatiously the money that came pouring into the coffers of the company. There were no smarter equipages in London than those which conveyed these financial magnates to and from their offices. No banquets were better served or better attended than theirs. No servants were more numerous, more handsomely liveried, or more ponderously respectable than those who attended them at every turn. For three years the West Middlesex throve mightily. Every day showed increasing receipts and extending influence. But there came a check. Mr. Barber Beaumont, who had taken a foremost part in the organisation of savings banks for the poor, and who was one of the most practical philanthropists of his time, called attention, by letter in The Times, to the necessary results of the low rates of insurance with high commission to agents offered by the West Middlesex. He also wrote in a Scottish newspaper, warning the people; and this letter aroused the interest of a Scottish editor and led him to undertake an agitation which ended only with the death of the concern. Ugly rumours were current in 1839 that the West Middlesex had failed to carry out its promises and had taken advantage of technicalities to refuse the payment of annuities and fire-insurance losses. 
While these difficulties were accumulating, came a blast from the Scottish Reformer's Gazette, of Glasgow, in which bustling town the company had an agency that was bringing large returns. Under the startling heading, "Exposure," this journal printed a stinging editorial characterising the concern as a "false and fictitious company," as " a quack company got up for the premeditated purpose of imposing on the public," and declaring that the policies of the company had a clause confining the liability to the stock and funds of the company itself, and that there was no value in these pretended assets, the parties in the company being financially men of straw and "no better than a parcel of tricksters." Putting the case squarely, the article went on, "There can scarcely, we think, be anything so base or nefarious as to take premiums from unsuspecting people, and making them believe they are secured against the contingencies of life, or the risk of fire, and yet mocking them in their calamities when the bubble bursts."

One blast upon the horns of exposure was not enough to fell the walls of this nefarious Jericho. The sharpers, entrenched behind the vast bulk of the wealth they had taken from the public, entered suit against the Scottish Reformer's Gazette and its venturesome editor, Mr. Mackenzie, and even sought to make further capital out of the public sympathy aroused in some quarters by what they called " persecution." They villified Mackenzie also, and assured the public that they would soon have him in jail and his newspaper suppressed. But Mackenzie was worthy of his Scottish blood. He fought the fight against the Southron as loyally and stubbornly as had Bruce when he opposed "proud Edward's pow'r" in the elder days. He resisted the suits entered, and continued to appeal to the public to withhold their confidence and their money from this gang of swindlers. But, swindlers as they were, these men knew nothing of that fear which causes the wicked to flee 


\section{Company Frauds}

even when no man pursueth. They were ready to play to the very last the bold game upon which they had entered. The more they were attacked, the more respectable they made their surroundings, the more they advertised the advantages offered by the company, the more lavishly they bribed agents and others to bring in business, and the more fiercely they fought, in the courts and through correspondence, the man who attacked them. Many newspapers were bought up by the patronage the West Middlesex gave, and thus the great guns of the press were worked against the similar guns worked at long range by Mackenzie.

In one curious way the swindlers had a great advantage. The law of that time in England was even more lax than it is to-day. That is to say, it embodied still more completely the principle of non-interference with the operations of people engaged in business. Since then, the natural concomitant of this individualism, publicity, has been insisted upon. Public opinion, backed to a certain extent by the law, has demanded that the facts concerning these public companies shall be laid before the public from whom they have received the privilege of a charter of incorporation. In the days of which we have been speaking, there was no such precaution. A joint stock company was regarded as merely a partnership; and every partnership was free to carry on its business as it pleased, so long as it paid its debts and did nothing to interfere with the Crown and the aristocracy. Consequently, until the West Middlesex Company failed to pay its debts and could thus be adjudged bankrupt, it could not be interfered with. Had the conspirators remained united, there is no saying how long the swindle might have been kept going. But the pressure from without alarmed some of those within; and, besides, jealousy of the vast gains of the leaders had made the smaller men feel that the ruin of the whole concern would not be without some compensating satisfaction to themselves. A very little of this 
kind of thing was enough to cause mutual distrust, and, as quickly as a spark breeds a flame in a pile of shavings, this distrust developed into panic. Knowles and Hole quarrelled, and Hole was at once ready to take part with Mackenzie, mainly for revenge upon his leader, by whom he believed himself to have been cheated, but partly also in the hope of being able to retain what he himself had taken out of the concern. The company dropped into ruin at once. It was found that practically all the money taken in, except that paid to those fortunate customers whose losses had occurred in time to enable them to realise, had been spent in salaries, advertising, and clerk-hire. "Bubble" companies such concerns are called, and well do they deserve the name, for they have merely attractiveness without substance; and, once pricked, they collapse, as the author of the One Hoss Shay so aptly says:

All together and nothing first, Just as bubbles do when they burst.

The loss occasioned by this gigantic fraud extended throughout the whole country. Into every town and hamlet, and even into remote country districts, the circulars and prospectuses of the company had gone, loosening the grip of hard-fisted farmers and suspicious dowagers upon the little hoards laid up in the funds, or, perhaps, in the cracked jug or discarded stocking so much favoured by those who live close and save hard. For over two years the golden streams had emptied into the strongboxes of the company; and at no time were these so numerous, so large, or so promising of increase in the future as at the time when the cry "Exposure!" warned the public of the judgment that was in store for them because of their avarice and folly. How much money the swindlers took in it is not easy to say. At this distance of time, it would be folly to attempt to calculate the amount. But Francis, from whom most of the foregoing facts are taken, estimates it at from $£^{2} 00,000$ to $£^{2} 50$, 000; or, 
say, something over $\$ 1,000,000$. And all this in the course of less than three years.

Is it any wonder that the example of Knowles and his partners fired to emulation the bosoms of many a budding Tigg Montague throughout England, or that the bubble companies increased and spread like a plague? Naturally the increase of swindles developed a demand for restrictive legislation, and the subject was taken up by Parliament. In the meantime, fortunately for the people, the press took up the question also. The Post Magazine, which still goes on its useful way, was founded in 1840 , and proved an able and fearless defender of the public interest. But, of course, the public would not all be warned. The crop of fools seemed to be unlimited and irrepressible. As soon as one swindle was exposed and suppressed, another took its place, the new ones very often promoted by the very men who had engineered the old.

The first efforts of Parliament to suppress the swindles by law were, as usual, half-hearted, ill-considered, and ineffective. And, as usual, laws which could not suppress all the swindles only furnished new safeguards for those swindlers who were keen enough and bold enough to take advantage of them. A law was passed in 1844 , but it did not apply the principle of limited liability to insurance companies. Thus the old condition of affairs was allowed to remain-an insurance company was a mere partnership, and any man of substance who subscribed to the stock became a partner and pledged his whole property for the debts of the concern. The effect of the exposures which were made was to warn away from the stock of new concerns all who had anything to lose and to make the organisation of a sound insurance company exceedingly difficult. The making of bogus concerns, however, went on unchecked by either law or exposure, so long as the scheme was found a good one for parting fools from their money. One concern which was started with a great fanfaronade of advertising 
in the City, and which went to pieces, was afterwards investigated, as were so many others, by a Parliamentary Committee. It was shown that the only names on the share-list that represented any property had been put there without any authorisation by the men who owned them. Of the other names, many were merely fanciful, representing neither man nor property. As Walford says, "Of those who turned up, all turned up bad." Some of the parties whose names appeared on the list were found, but, practically without exception, they were men without property, and some of them had worse than no reputation. One man said he signed "because others did"; another that he had signed "for a pot of beer." Such men could well afford to sign anything that was laid before them, and, if they got a pot of beer or anything else by it, they were just that much to the good.

It was not until 1862 that the principle of limited liability was fully applied to insurance companies. Since then, it has been possible for a man to venture a part of his property in an insurance enterprise without risking the whole of it. There has not been the same reason, therefore, for confining this business to men who had nothing to lose. Up to the passing of this statute of 1862 , the whole question was in a confused and uncertain condition. As swindlers became more active and barefaced, a cry would be raised, Parliament would be moved to more or less unwilling action, investigation would be held, and the unfavourable advertising would, for a time, drive the schemers into retreat. Then, Parliament and public satisfied, the agitation would cease, and, in a few months, the energetic issuers of bogus policies would be as active as ever. Walford gives a list of about two hundred and fifty companies that retired from business from 1844 to 1867 , an average of about ten a year. Of these, some, of course, were bona fide concerns, but unfortunate. The vast majority, however, were merely intended to benefit their promoters; and those who 
trusted them with money were losers to a greater or less extent. Of eight that are marked "a swindle," every one was formed and died between $185^{2}$ and 1854 , indicating that the business of swindling insurances was very active just before the parliamentary investigation of 1853 , and that it declined rapidly after that, at least for a time.

It would be unfair and absurd to calculate that the retirement of ten insurance companies every year meant ten times as great a loss each year as through the West Middlesex swindle. But it is quite fair to assume, that, with gangs of swindlers at work organising companies so rapidly that for nearly a quarter of a century they were forced out of business at the rate of almost one a month, there was great and widespread loss, and that the losers were not the sharpers who organised the companies. The facility with which these rogues caught unsuspecting people caused public men and those who felt an interest in the welfare of their fellow-citizens to almost despair of ever stemming the tide of falsehood and robbery. As the Commissioner remarked, in Thackeray's account of the West Diddlesex company: "But what's the use of talking? Here is one rogue detected and a thousand dupes made; and if another swindler starts to-morrow, there will be a thousand more of his victims around this table a year hence; and so, I suppose, to the end."

But it was not really quite so bad as that. Wise legislation -for ultimately wise legislation was passed-constant hammering into the thick head of the public the principles of sound investment in insurance, and that slow-moving but undeviating combination of forces that compel men to be honest in transactions that are to be repeated, have brought about a great improvement of conditions in Great Britain. And they will thus remain unless and until some change in financial methods makes it possible for sharpers to spring upon the public schemes that have never yet been tried, and against which 
there is neither legislation nor enlightened public sentiment to act as a safeguard for the interest of the common people.

As already stated, I have no intention of trying to summarise the history or results of this form of robbery in the United States. By the outbreaks dealt with in the next two chapters, the reader can judge what goes on more quietly and more diffusedly all the time, to the demoralisation of industry and of public sentiment and the almost open robbery of the best class of the population. The position of affairs in the United States affords, in some ways, special facilities for this kind of swindling. It is no part of my purpose to criticise the American system of government. Assuming, however, that it is the best hitherto possible, it has its limitations, and, because of those limitations, disadvantages. One of the difficulties Americans must face in regard to swindling insurance companies is that of State control. Even where the control by a State of its own insurance creations is perfect, there is always the difficulty of regulating the operations of companies from other States. It would have been mere folly-no doubt everybody will agreeto confine to one State the operations of some of the great insurance corporations of New York, Boston, and Hartford. Yet, just how to construct an entrance into every State which will automatically admit these beneficent concerns, and yet unfailingly shut out mere wildcats, is one of the problems to be faced. As a matter of fact, it is by no means agreed that even the State laws controlling home corporations are exactly what they ought to be in every case. And, even where they are now perfect, there is always danger that some well-meaning but not omniscient legislator will seek a change in order to meet some case which he supposes to be unique, only for himself and his people afterwards to find that he has affected injuriously the running of the whole machine, and made it possible for whole gangs of swindlers to cause it to run partly for their own benefit. But, great as these merely domestic 


\section{Company Frauds}

difficulties are or may become, they are as nothing compared with those arising from the attempts to regulate concerns from other countries and other States.

One has only to glance through the reports of the Commissioners of Insurance for the several States to find how universal, and how serious this difficulty is. Here, for instance, in the report for I9or of Commissioner Barry, of Michigan, is the warning to the public that many outside companies are seeking to do business in the State without conforming to the requirements of the State law with regard to registration and so on. These companies, says the Commissioner, are all unauthorised and their contracts unenforceable, and the agents who effect insurances for them are personally responsible in case of loss. He goes so far as to give a list of the wildcats whose operations have been called to his attention.

But, instead of going through the whole library of State reports, we more conveniently refer to a most satisfactory compendium, the Cyclopadia of Insurance in the United States, published in Hartford, Conn., by the Insurance Journal Company. The volume for $1900-190 I$ is the latest at my hand. In this we find summaries of the more important features of the several State reports.

Mr. H. H. Stevens, who was Mr. Barry's predecessor in the Commissionership, reported in effect as follows, according to this summary:

The great question for future solution, he said, is how the fraternal benefit system can be made permanent, and he hoped the I,egislature would find some way to protect the interests of the masses, that the laws would become their strong protector, instead of a cloak under whose garb most any smooth-tongued charlatan is allowed to juggle with the highest interests and welfare of the people. It is astounding, he said, how well and cheaply some of the fraternals were furnishing indemnity and were doing a magnificent work, but others were conducted in the interest of their officers, with only incidental protection to members. 
Mr. Frederick L. Cutting, Commissioner for Massachusetts, discusses a detail of the life business known as the one-year contract and says that it goes without saying that this policy is never truthfully explained to the public or applicant, and, if it was the applicant would not buy it. The Commissioner holds such contracts, the terms being what they are, to be continuing contracts and not yearly contracts, and denies the reasonableness of the system that would make them otherwise for the mere advantage of the company by enabling it to avoid the reserve charge which would otherwise attach. The summary goes on:

It seems to come to this: Shall the law be twisted and falsified to accommodate an unnecessary and unjust condition into which the business of the company has foolishly, if not wickedly, drifted, or shall the business be admonished to return to reasonable economies and business methods?

Mr. Edward S. Schofield, Commissioner for Connecticut, in dealing with fraternal insurance and the need for a reserve fund, is represented as expressing an opinion which is thus summarised:

The sooner these associations are brought to realise what should be done in this respect, the better for all concerned, and the Commissioner added, if the present plan is persisted in, it will result in stranding on the shore of disappointment many thousands of insurants who now rest content in the belief that their certificates will give to their dependents all the beneficent fruits of time life insurance, while the fact is that temporary insurance only is being furnished. The Commissioner said that legislation should speedily be had requiring the associations to comply with the law in the matter of a reserve.

Col. J. R. B. Van Cleve, Superintendent of Insurance for Illinois, in his report for 1900 , complains of fire-insurance companies which make a practice of establishing headquarters in Chicago, though not authorised to do business in the State, and usually not authorised in any State, which companies are, as a rule, worthless, fraudulent, or mythical concerns and have not 
the financial standing to comply with the laws of any State. The representatives of these concerns are mere insurance pirates or freebooters. Their scheme the Superintendent declares to be less fair than a lottery, the promoting of which the criminal law prohibits; and it would seem that the criminal law should provide for these insurance swindles also. He recommends a change in the law to meet the case.

Mr. J. A. O'Shaughnessy, Commissioner of Insurance for Minnesota, speaks of over-insurance in fire risks as increasing the moral hazard and offering an incentive to both incendiarism and negligence, and condemns agents who over-insure property, especially buildings. In regard to fraternal life insurance, he said, the time had come when the law should be amended so as to better protect citizens. He complained that under the then existing law, nine persons with only eleven dollars among them might organise a company, the Insurance Commissioner having but little discretionary power to control such concerns, but was compelled, if these parties complied with the easy technicalities of the law, to turn the venture loose upon the public regardless of the business ability and integrity of the promoters. He suggests rules of business economy with which these people should be obliged to conform.

These examples, chosen almost at random, are sufficient to illustrate the difficulties arising from the multiplicity of bodies. empowered to make laws governing insurance corporations. It is hardly to be wondered at that the abuses suggested in these extracts sometimes become very grave. It is only wonderful that the epidemics are not more frequent and more serious. Just how serious they may become, however, is shown in succeeding chapters.

It would not be right, however, to leave this part of the subject without mentioning an abuse which may grow out of this variability of State laws. This abuse is alleged to exist; it is frequently mentioned in the insurance journals. One can 
easily see how it might arise and how necessary it is to guard against it. I do not seek to make a strong point of it here. Producing no evidence to show that it has ever existed, I speak of it, not as a fact, but as a possibility. Some of the great insurance companies have revenues a good deal greater than some of the States of the Union. These concerns, great as they are, can do business in each State only under authority of the State Legislature and under conditions fixed by State law. A change in that law may grievously affect the interests of these gigantic concerns. If a selfish and corrupt gang gain influence in the Legislature of an important State, it would be possible for them, by introducing a measure amending the insurance law, to threaten these interests. In such a case, the companies would naturally seek to convince the members of the Legislature of the injustice and inexpediency of the measure. If the gang could not be satisfied except with money paid in hand, it would be for the company to consider whether it would do better to submit to this corrupt exaction, or to accept the law and try to live under it, or to accept the law and withdraw from the State. It is alleged that companies that are really weak, though of imposing size, have paid the tribute rather than risk the results of laws thus unfairly directed against their interests. It is even alleged that this tribute has been systematised in some instances, for a time at least. "Strikers" such legislators are called in the insurance journals. If this abuse became wide spread, it would be a menace to free institutions and to the safety of the Republic. The fact that it is but little referred to outside of insurance circles would indicate that, even if there ever has been such a levy it has not reached the proportions of a general abuse. It is alleged, sometimes with strong emphasis, that this evil is apt to manifest itself in the executive as well as in the legislative branch of government. The most grievous cases alleged are those of large concerns which have fallen upon evil days. The soundness of 


\section{Company Frauds}

every company being a matter which it is the duty of the insurance officers of the State to make sure of, every company is subject to close examination at any time. A great company whose name is called in question might gain the favour of a corrupt official by means other than a frank exposition of its affairs and proof that those affairs are in sound condition. On the other hand, a corrupt official might compel the payment of tribute to himself or his political party by a company, under covert threat of using his office to give to the public an unfavourable view of its position and operations.

It will be observed that, in case of these abuses arising, insurance companies, from their very nature as already explained, would be most likely to share in or suffer from them. No matter how strong financially a company may be, its greatest asset is its reputation. The complexities of the business, the vast number of people the companies have to deal with, and therefore the danger of arousing public prejudice or resentment, the immense sums of hard cash they have in charge-these and other considerations would make the insurance companies a shining mark for the "striker," should such a man exist. In this case, as in all others, the very fact that there is here a specially grave danger makes it all the more necessary that public sentiment should be well-informed and vigilant. So long as the people see with understanding eyes the deeds of their representatives, there is little danger that those deeds will be the result of conspiracy against the public welfare. 


\section{CHAPTER XVII \\ COMPANY FRAUDS-Continued}

"Graveyard" Business-Experience of Pennsylvania-How the System Arose-Its Terrible Effects-The Bubble Pricked-Danger of Neglecting the Law of "Insurable Interest."

$\mathrm{O}$

$F$ all the lapses of life insurance into the folly and crime which attended its early growth, none is more remarkable or more disturbing than that which has since been known as the "graveyard" or "deathbed" insurance craze of the early eighties. This outbreak was most painfully manifest in Pennsylvania. And, as the experience of that Commonwealth is enough to illustrate the case, I shall not go beyond it. But I should like it to be understood that the records of Pennsylvania do not, by any means, cover the whole facts of the case. The disease was epidemic in many other States, and brought disaster and demoralisation wherever it appeared. From facts given here, however, the results in the other communities can be inferred. For these facts I have the authority of the reports of Hon. J. M. Forster, Insurance Commissioner of Pennsylvania, for the years 1879 to 1883 , inclusive, except where some other source of information is named.

There is, as suggested in previous chapters, a form of insurance under which the fund to meet losses is provided, not in advance of the loss, but subsequent to it. Thus, for instance, a thousand people form an association to insure the life of each for one thousand dollars, each party to pay pro rata to make up the amount whenever a death takes place among the members. To make this insurance real-to make it insurance in 
more than name-the parties must pledge property or good names to back their promises. If this is not done, it is practically certain that none but the earliest claims will be paid; because, as the average age of the members increases, the claims naturally grow in number, while those who are left to pay become fewer in number. The burden, in time, becomes intolerable to those who can insure in cheaper fashion, and these withdraw, leaving those who have no other resource, and who dare not forfeit even the poor advantage they have paid so much to gain. Ten thousand trials have proven, if such a thing can ever be said to be proven in a world in which, as the philosophy of the under-world tells us, " there 's a new sucker born every minute," that even with honesty the scheme is not practicable. But the new crop of enthusiasts always seem to see possibilities in it, and they risk their own and others' future on an attempt to work it out in a business way. And there always seems to be a new succession of knaves ready to use this idea as a confidence game to gain money from others. When there is no honesty on the part of those who seek to carry out such an idea, there is simply no end to the evil that may be wrought. The operation descends through the whole range of wrong doing and crime, not stopping short of murder. And, if not checked, every part of the operation, including murder, becomes recurrent and, at length, systematic.

It was the misfortune of Pennsylvania, about 1879 , to have two very bad features in her law; - or perhaps it would be more accurate to say that it happened that schemers found two weak places in the law through which they might break and so rob the people with impunity, for a time at least. The first of these defects was a lack of special provision for the formation . and control of assessment benefit societies. Such societies were thus left to be formed under a general law which had been used for the formation of many small local mutual fire insurance companies. In the case of fire insurance, there is not the 
same danger to be guarded against as in life insurance, and, at the same time, the very nature of the fire business checks the too free formation of these small companies. Under the law of which we speak, any ten or more persons might agree in writing to form an insurance company. This agreement went to the Insurance Commissioner, who passed upon the title of the proposed association. With their name approved and certain other simple formalities complied with, the new concern might be constituted a corporation. I assume, though it is not specifically so stated, that the Insurance Commissioner, the Attorney-General, and the Governor, each of whose approval was required at some stage of these proceedings, might fairly regard the law as mandatory so long as the proposal was in due form. No inquiry was to be made into the standing of the parties, nor was any money security or any other evidence of good faith required. After incorporation, the concern was required to receive applications for insurance at convenient times and places until not less than two hundred thousand dollars of insurance was subscribed. With this amount placed, the concern was not only incorporated, but authorised to do business with anybody. Under such a law, the making of a "Mutual Life Insurance Company" or "Mutual Benefit Association," or whatever the promoters chose to call it was as easy as the proverbial rolling off the proverbial log. It was far easier than making a "Mutual Fire Insurance Company," for the schemers, or the schemer and his first nine dupes, had only to agree to take twenty thousand dollars of life insurance each, or to find takers for that amount, and the new financial concern was duly incorporated and in full swing of business as properly authorised by the laws of the Commonwealth of Pennsylvania.

At the same time, a decision of the courts declared in so many words that beneficial associations were not "insurance companies" under the law and could not be controlled by the Insurance Commissioner. The reason alleged was that an 
insurance company promised to pay a fixed amount on the happening of a certain event, while the beneficial association considered itself merely the agent between the claimant and the members of the association, its only duty being to assess the members on a claim arising and to pay over the amount realised to the claimant. Thus these mutual concerns, growing in this mushroom fashion, were able to offer "mutual life insurance" under the very letter of the law governing the formation of mutual-insurance companies, while, at the same time, they were not held to any of the obligations or subject to any of the penalties of insurance companies. Taking the money of an applicant, one of these concerns was a mutual lifeinsurance company, but when it came to adjusting a claim, it was a mere beneficial association.

This would have been bad enough. But, when it was combined with a second weakness in the law, it was fatal to the peace of the Commonwealth. This weakness was more in appearance than in fact. It was as though the policeman whose duty it was to keep trespassers off a certain property had been for the moment removed, and the schemers, acting on the principle, "go ahead until you 're ordered back," had rushed in before he could be replaced. The difficulty arose from a court decision, one sentence of which, taken by itself, might be held to mean that the good old law of "insurable interest" did not exist for Pennsylvania.

From the account of the case given by the Insurance Commissioner, it would seem that the courts did not commit the blunder-it would have been a blunder far worse than a crime -of repealing or destroying this salutary law. The case was one in which W. Cunningham \& Sons, parties with money, entered into business relations with one Jerome Smith, who was, apparently, without capital, the conditions of agreement making it necessary for the latter to reside in Vera Cruz, Mexico, and handle goods in the interest of all. Thus, while 
the moneyed men expected to make a profit, yet, in the course of the transactions to follow the signing of the agreement, they would be put to heavy expense and would be obliged to face the risks of serious loss, those risks being appreciably increased by the danger of the death of Smith through the unhealthfulness of the climate of Vera Cruz, especially to one northernbred. To protect the Cunninghams' interest, Smith's life was insured in their favour. The interest of the Cunninghams in Smith's life was, thus, clearly a financial and bona fide one, even though it may have been, in part, contingent. Smith died, and the Cunninghams received the insurance money. Suit was brought by the widow to recover from them, alleging that the assignment of the policy was merely to protect the parties from loss on advances made to Smith. The decision of the court was favourable to the Cunninghams, on the ground that the Cunninghams, in making the arrangement, might well look forward to the contingency of losses and expenses other than those which would result from the failure of Smith to refund the advances made to him, and had a right to protect themselves against such losses by becoming the beneficiaries of Smith's life insurance. But the decision contained this unfortunate sentence: “But Jerome Smith's interest in his own life was unquestionable, and, if he was willing to insure himself with their (the Cunningham's) money, and then assign the policy to them, there is no principle of law which can prevent such a transaction."

It was a small opening, 't was not so deep as a well, nor so wide as a church-door; but 't was enough, it served. It came at the worst possible time. And it was used to the uttermost by the schemers, who saw in it a short cut to enormous wealth. To complete the combination of misfortunes, it happened that - this decision synchronised with the first great outburst of assessmentism in the United States. This we can see by a glance over the files of any insurance journal of that time. 
Subsequently, it is true, came the best days and the greatest influence of this system; but at the time of which I write it had great vigour, even though it had not reached the proportions it afterwards attained. A number of steady-going assessment concerns, honestly managed and yielding great benefits to those who dealt with them, were in operation in Pennsylvania. Other concerns, nominally of the same kind, but managed by unscrupulous persons for their own benefit, had pushed in from Ohio, where assessmentism was particularly strong. I find a statement in one insurance journal that Pennsylvania had long been a favourite ground with the insurance fakir. One would be led to think so, from the readiness with which the people went into the "graveyard" concerns. In one short year from the beginning of this wretched system, the evil had spread throughout the State, and even beyond it. Of course, the epidemic was not equally bad in every part; and many sections of the State were comparatively little affected.

The nature of the evil has already been indicated. The insurance fakir found it practically possible to make an insurance company without difficulty and without check or responsibility. $\mathrm{He}$ found it possible also to insure the life of another for his own benefit-in fact, to carry on, unhindered, and in a rich community, the old, discredited game of gambling in lives.

It was like the breakdown of a fence around a turnip-field before a drove of hungry hogs. The scheme was taken up and pushed with enthusiasm. An idea of the rapidity with which this new social disease spread is conveyed in the single fact that, in the year I880, no fewer than ${ }^{3} 3^{1}$ of these mushroom concerns came into existence. Considering that twenty-nine of them were in Dauphin County, in which Harrisburg, the State capital is situated, and fourteen in Harrisburg itself, it is hardly wonderful that the Insurance Commissioner devotes about a quarter of the space in his general report for the year to this new gambling system. It must have seemed like a 
touching appeal for the protection of the law for their new industry when the schemers thus centred their operations in the State capital. The Commissioner's report for I88I shows even greater activity on the part of the new "fraternals." The volume is actually made about fifty per cent. more bulky than the average of its predecessors, in order to accommodate the returns of the new institutions. There were then $15^{2}$ of them, nearly all in full swing. The increase went on up to the moment of the collapse, which came very soon; for the Commissioner, in his report for 1882 , was able to say, "the speculative business is at an end."

That end came none too soon. Had the craze continued much longer, it would have utterly demoralised the State. The object of the ordinary life-insurance company is to select its risks with the greatest care, for nothing can be more certain than that every policy which is continued will become a loss; and the only way by which the company can avoid disaster is by having the claims mature, on the average, after the money paid in amounts, with accumulations, to more than the claim. But with these bubble concerns, the case was vastly different. They did not intend or expect to pay all claims, but only to pass the hat when a death occurred and pay over to the claimant a certain portion of the proceeds. The more deaths, the more collections; and the more collections, the greater the amount of the "rake-off" for those who managed the concern. At first, probably through sheer force of fashion, a medical examination was required of everybody insured by these concerns; but, when it was found, as it was very soon, that this interfered with business, it was first evaded and then cast aside. "No medical examination" was the catch-penny phrase with which many of the graveyard associations headed the literature with which they flooded the State.

To be in a position to realise on his claim when it arose, the player of these fearful wagers upon human life must keep his 


\section{Company Frauds}

nominee a member in good standing; and, to do this, he must pay assessments as they were made. As a man did not insure his own life, but the life of somebody else for his own benefit, it will readily be understood that the subjects chosen, as a rule, were those likely to die within a short time. As the Insurance Commissioner put it, "the nearer the grave the better the risk." In fact, this was a game in which speculators made bets upon the race to the grave among those who seemed most likely to reach that goal speedily. The speculator had two facts constantly in mind; first, that too long a life on the part of the person upon whose death the wager was laid would make the repeated calls for assessments an intolerable burden; and, second, that there was every danger of the company itself going to pieces and leaving the speculator drained, with nothing to show for his money. This gave more than zest to the game,-it drove men stark lunatic, and demoralised every community that it touched.

In the old gambling in life insurance, of which this was a revival, the bets were generally made between men of equal standing and of some substance financially-such as underwriters at Lloyd's or brokers on 'Change-and on the lives of rulers, prime ministers, and others who, in the ordinary way were not directly under their control. But in the graveyard craze in Pennsylvania, there was the added and terrible evil that the persons insured were often old, broken-down paupers, chosen because their end was believed to be in sight and because their death could be learned and reported as soon as it occurred. Another class of risks consisted of the parents of the first-hand speculators, often invalids who, the gamblers had good means of knowing, could not expect to survive long. That this was a common practice is shown by the peculiar literature to which this craze gave rise. One concern, advertising for agents, held out hopes of from twenty-five to a hundred dollars a week-immense wealth to the farmers' sons and 
others whose services were sought-and said, "You will have no trouble to talk sons into having their aged parents insured, thus securing a nice thing for them and a sure profit for yourself." This has a gruesome look.

Could we forget the wickedness of this traffic, there would be something downright laughable in the way it was carried on. A speculator who had mind to go into this game would find some aged, infirm, and poor person to whom life insurance was nothing, but to whom a small donation of money or whiskey was a consideration. This old person would be "in. sured" for as large an amount as the speculator felt he could handle to advantage. The gambler would then take a transfer of the certificate, thus making himself the beneficiary in case of the old person's death. If fortune smiled and the " risk" died at once, the speculator made a big haul. In one case, a man paid the entrance fee for an old pauper, and, next day, had the gratification of finding the old man dead and himself worth five thousand dollars by reason of the transaction. But, in any case, a policy upon a "good risk" was recognised as wealth. Should the speculator find himself unable to hold on, or should he prefer ready cash, he could sell out his certificate. In less than a year from the beginning of the craze, certificates of this kind were dealt in and passed from hand to hand like stock certificates. One of the most marvellous things in all this remarkable exhibition of degeneration was the quickness with which the business was systematised. Agents were set at work in every part of the State as quickly as though men trained to the work had been waiting in the market-place to be hired. These agents were allowed to retain, of the money collected by them, from five to eight dollars for every one thousand dollars of "insurance" secured. The fee was a good one. Many a man left his plough or his bench to engage in this business; and hundreds of them were forever unfitted for the plain, everyday duty of earning a living by honest labour. 
Men with more or less capital were found who would readily undertake the paying of assessments in the hope of a rich reward to follow. Schemers with some capacity for organisation, desiring to sit at the receipt of custom, formed associations of their own, presided at board meetings, signed checks, and lived high.

The effect upon the common people of this sight of fakirs and diddlers growing rapidly rich by means of this game can be imagined. It was as though the possibility had suddenly arisen of finding gold double-eagles on every farm and in the streets of every town. Industry was neglected, and nothing was thought of or talked about but this new opening to early wealth. Storekeepers and others found money scarce, and no wonder. Their customers had assessments to pay, and these must be paid; for otherwise, not only would the great stake for which they were playing be lost, but so also would the sums which, with so much difficulty, they had already wagered in this fascinating but immoral game. The Insurance Commissioner, in his report for I880, said, with Turk-like resignation, that the craze must run its course, like the oil mania of twenty years before; no appeal to reason, common sense, or humanity would avail to stem the tide-nothing but the bitter experience of ruin would show the people their real position.

And so it proved. The dream was a deliriously blissful one, while it lasted; but the awakening was terrible. Fortunately, the mania was hastened in its course. Otherwise, it would have devastated the industries of the State. The experience of England with similar crazes warned the authorities of what might be expected; and, finding the people deaf to their first mild warnings, they took more drastic measures. In this they were heartily supported by public opinion; for the great majority of the people still retained their sanity, and respectable citizens were scandalised by the reputation the Commonwealth was acquiring because this indecent and demoralising 
system of gambling in human lives was tolerated within its borders. The press urgently demanded reform; and, as is the fashion, and perhaps the privilege, of the press, indulged in a good deal of ill-natured and unjust criticism of the executive officers of the State, whom, jumping at conclusions, they believed to be guilty of supineness and neglect. The Insurance Commissioner, especially, was appealed to to do something. Considering that the Insurance Commissioner had been the very first to point out the difficulty and to warn the people of the results to follow a failure to change the law and give himself or somebody more power in the premises, this seemed a trifle, so to say, unkind. However, the Commissioner tried to use such powers as he had to the best possible advantage in checking the mania. As already stated, a mutual insurance company could not be incorporated until its name had been approved by the Insurance Department. Standing in the breach, the Commissioner refused to approve any name whatever in cases where he felt morally certain that the proposed association was a graveyard concern. Whatever credit he might deserve for good intentions, he was clearly going beyond his powers. The people of Pennsylvania had entrusted the making of the laws to their representatives in the Legislature; and for the Commissioner to make a new law under guise of enforcing an old one was hardly to be allowed. The schemers complained loudly, and threatened trouble. On consulting the Attorney-General, the Insurance Commissioner found that the law would not uphold him in thus bodily blocking the way of the graveyarders. So he was obliged, however unwillingly, to give his formal approval to names chosen for new concerns, even when he knew that this approval would be used as a cloak for the most hideous of gambling. He continued to call, as he had done from the first, for a change in the law which would make it possible to head off the swindlers. In the session of I88I, a bill designed to abolish the traffic was passed 
in the State Senate; but, owing to bad "steering," as it is called, it failed to pass the House of Representatives. Few members of that body voted against it, but the measure failed to secure the necessary majority, and, having been brought to the House late in the session, its supporters did not succeed in pushing it through in the final rush.

The effect of this failure was to give the traffic a sort of inferential legislative endorsement; and the schemers and speculators, who had been held in check by the threat of a new law, took heart and went on their way more brazenly than ever. But this was the one thing that assured their destruction. Had they made any sort of concession to public opinion, had they even made themselves less conspicuous, they might have been allowed to go on for a while longer. But, as the Insurance Commissioner said in his report for I88I, "it became necessary to devise some means of checking them." The necessity brought forth the invention to do the work. Just how far that invention was in accord with the law or constitution of Pennsylvania, I do not find the material to enable me to discuss. It may have been all right in this respect; but, if so, it is a pity, considering the simplicity of it, that it was not thought of sooner. On the whole, perhaps, the authorities may have taken Bassanio's advice to the court:

And I beseech you,

Wrest once the law to your authority :

To do a great right, do a little wrong ;

And curb this cruel devil of his will.

In November, I88I, at the request of the Insurance Department, the Attorney-General of the State commenced proceedings by writ of quo warranto against two companies, with a view of determining their powers and obligations under the law. Information was also laid by the Insurance Commissioner against three of the largest of these concerns under the law of their 
incorporation, and a thorough examination of their affairs was made. Proceedings to inquire into the propriety of the dissolution of certain other concerns were taken in the spring of I882 under information laid before the Attorney-General. Subsequently, the law was invoked, in one way or other, against the whole brood. These latter proceedings were hardly necessary, for before they were begun the gamblers had taken fright and broken up the game. Nobody in the whole miserable gang had any confidence in any of the others, or any doubt that the game they had been playing was a thoroughly dishonest one; and, the moment the officers of the law decided to interfere, there was a general rush to get out of range. It could hardly be said that the associations broke down or became bankrupt; they simply went out like a prairie fire that has reached an impassable river. The legal proceedings were not only not contested, in most cases, but there was so little of the concerns left that there was hardly ground for legal proceedings at all; and the business of the court was not to question their right to live, but merely to officially record their death.

And what were the results of this craze, as they appeared to those who had to deal with its poor remains? Disastrous enough, as we can see from the reports of the Insurance Commissioner. Altogether, 236 associations nominally of the same kind were incorporated. Thirty-seven reported to the Department as late as $\mathrm{r} 882$, and so may have had some honesty in them. A few of these were allowed to carry on business, on engaging to comply with the law as interpreted by the courts. The remainder were either suppressed by the courts or failed to make themselves heard in any way. Many of these organisations were small, their promoters not having money or ability enough, apparently, to push them into prominence. What they might have been able to do had time been allowed them it is, of course, impossible to say. Many were so completely and frankly mere gambling concerns that the promoters did 


\section{Company Frauds}

not comply with even that part of the law requiring a report of their proceedings and demanding the payment of a tax by them according to the number of their agents. For these reasons it is difficult to say what amount of money was actually taken by them from the public. Another difficulty is that among these concerns are officially classed a number of honest institutions carrying on business on the assessment plan, institutions that had existed before this mania came on and continued to exist and do good after it had passed. Which were honest and which dishonest, it would be hard even for one well acquainted with the facts to say with certainty. We must lump the good and the bad together, therefore, in the following table, which is designed to show something of the money loss to the community resulting from the operation of the graveyard insurance associations:

Table showing receipts and payments for death claims and for salaries and other expenses by assessment life associations in Pennsylvania, for the years 1879 to 1882 , inclusive.

\begin{tabular}{c|c|c|c|c}
\hline Year & $\begin{array}{c}\text { No. of Assns. } \\
\text { Reporting }\end{array}$ & Total Receipts & Paid Death Claims & Paid Expenses \\
\cline { 2 - 4 } & 23 & $\$ 866, \mathrm{I} 69$ & $\$ 606,320^{\prime}$ & $\$ 259,850^{1}$ \\
1879 & 42 & $1,353,988$ & 906,867 & 403,900 \\
1880 & 152 & $3,045,994$ & $1,541,566$ & $1,479,974$ \\
1881 & 37 & $1,021,087$ & 746,148 & 253,957 \\
1882 & & &
\end{tabular}

The table indicates that the graveyard-insurance traffic lasted about two years. It was gathering force in 1879 and 1880 , came to its greatest power in $188 \mathrm{I}$, and was crushed before the report for 1882 was closed. The increase from 1879 is not an: increase on the part of the honest concerns; every dollar of it: is growth on the part of the graveyarders. But even more was: thrown into this gambling game than is indicated by the official reports. As will be seen by the figures already given, about one-third of the whole number of these gambling associations did not report to the Department at all. Besides that, ${ }^{1}$ Approximate. 
it appears that, even of those that did report, many failed to include in their statements sums which were retained by agents -the officers being so ignorant that they assumed that the receipts of the agent were the private concern of the agent himself and had nothing to do with the revenues of the association. The moneys retained by agents, according to the Insurance Commissioner amounted to about $\$ 262$, 077 more than was reported for the year I88I alone. So that the total amount taken by these gamblers from the people can only be estimated by including these figures. I do not find anywhere in these reports an estimate of the total amount lost by the people of Pennsylvania through this swindle; but, even assuming that the money won by the gamblers in the form of death claims was a gain to the people and represented so much capital restored to honest industry, and asuming that that money which was given to officers and paid for expenses was lost, we find that the loss amounted to two million dollars for the year I 88I alone.

The loss was not confined to the merely reckless or to those who could afford to lose. Many a farmer starved his family or his land, many a one mortgaged his place, many a one incurred debts under which he staggered for years, in order to raise money to wager in this great swindle. In a sense, even these, poor though they might be, deserve no sympathy, for they went in hoping to gain, and to gain by conscienceless, wicked gambling in the lives of those whose infirmities and whose nearness to the grave should have made them objects of reverence and tender care. Many of the graveyard companies were such reckless, barefaced swindles that they could hardly have been thought of, except by men who were so absorbed in watching their chance of winning that they could not devote a moment's attention to the man who dealt the cards or managed the table.

These nominally mutual concerns were proprietary to an 
extent that would not be dreamt of in an ordinary joint-stock company. Many of them, for instance, had rules by which it was provided, not merely that the directors should have perpetual succession, but that on the death of a director his place should devolve upon his heirs, like any other property. The members had absolutely nothing to say about the disposal of their money after it was put in the pool. The advantage to the directors is shown by the figures given by examiners and receivers. One of the large associations, chartered in November, 1880 , paid to its directors, as salaries for one year, the sum of $\$ 32,220$, or an average of over $\$ 3200$ a year to every director, even supposing that there were ten of them, which does not seem to have been the case during the whole year. Just what the duties of these directors were does not appear, but they could not have been very onerous, for there was a full staff of executive officers and plenty of office help. And yet the books were so very inefficiently kept that the examiner who reported on the association said that the examination "was rendered exceedingly difficult and unsatisfactory by the absence or deficiency in the books and records of the association." In the case of another of these concerns, the amount paid to the secretary from the admission fees alone was $\$ 18,638$. This covered the period from March, I880, to the Ist of November, 188I. What other sums, if any, were paid to the secretary does not appear; but it does appear that this highly paid official did not fulfil his duties, for the examiner found that there was no cash-book, and that, from the Ist of March, I880, to the Ist of August, I88I, nu record whatever was kept of the receipts and disbursements of the concern. A list was made of the certificates issued and marks made to show the admission premiums paid, and this was the only record. As the examiner said:

The Secretary individually took all moneys paid to the association, and divided the admission premiums among his fellow-officers, paid the 
expense of carrying on the business, collected all assessments for deaths, and paid such claims as were paid, without keeping any account of such receipts, collections and payments, except as he kept them mixed with his private affairs.

Such accounts as were made up afterwards of the receipts and disbursements of the concern were made up from such scraps of records as were available, patched out with the verbal statements, from recollection, of the parties concerned. One association that had received $\$ 76,502$ had paid $\$ 15,697$ for death losses, and had $\$ 570$ on hand when it was examined. So that, for their work in carrying on the company, the agents, officers, and other employees, after paying out for printing, stationery, and other small expenses certain petty sums, had pocketed what was left - about $\$ 60,000$. A good many of these associations, afterwards taken over by receivers, had not sufficient assets to pay postage on assessment notices which should have been sent out. But, even when assessments were made by receivers, they realised nothing. It was like calling on players to "chip in" after the gambling-house had been raided. Such facts as these go to show that the money loss to the people through the graveyard insurance craze was far greater than the official returns would indicate.

Without palliating the offence of those who ventured their money in this swindle, and without seeking sympathy for them, it may be pointed out that, from the point of view of the public interest, much injury was done by the fact that many of the gamblers were utterly ruined through having held on too long. When the examiners and receivers took up their work, they found, in many cases, that claims duly accrued by the death of the "risks" and properly filed had not even been assessed for, and so, of course, had not been paid. This meant that men who had paid heavy assessments for others, men who had shown such honesty as was possible in such a game, by complying with the rules of the game, and, perhaps, in doing 
so, had incurred heavy debts, were left without a dollar. However well deserved and even salutary such a lesson may have been to such persons it could hardly be advantageous to the community; for, being repeated many times in the same section of country, it could not but effect injuriously all the industries of that section.

The money loss, however, was the least important question involved. The real disaster lay in the crimes brought about by this craze and the demoralisation it spread throughout the community. This has already been referred to in a general way; but the point may be treated with greater definiteness here. The temptation to murder those upon whose death large sums were wagered is obvious. These "risks," as already stated, were old people, almost invariably, and many of them were women. Those for whose benefit, in the first place, they were insured, were, often, their children, or the wives or husbands of their children. Of course, in many cases -in the majority, I believe, but that cannot be proven,- - the certificate was sold to a speculator almost as soon as it was made out. At least it is a satisfaction to think that, where this was done, those in charge of these poor, old, helpless people did not retain a direct money interest in their death. In fact, I fancy, a striking case could be made out for the graveyard concerns, with sympathetic and credulous people, by showing how they enabled many a son to raise money in advance on his invalid mother's insurance, and so to provide comforts and medicines to prolong and make happy her declining days. But the fact still stands that there was no guarantee that the interest in any certificate would remain in the hands of a good class of people. The most conscienceless reprobate in the State might buy in the open market an interest in the early death of some person whom he might have completely in his power. There is only one hint in the official report of murder done or death hastened by unfair means for 
insurance money, outside of the one notorious case which will be mentioned later. That one hint is conveyed by the examiner of one of the defunct associations, and it has a gleam of sardonic humour worthy of Artemus Ward. He says:

The number of persons who have died in proportion to the number holding certificates is exceedingly large, even after taking into consideration the advanced age of the insured, indicating that the association selects a very poor class of risks, or possibly, becoming a member of this association does not have the tendency of prolonging the life of its members.

But to the credit of all be it said, in this respect at least the game seems to have been played fairly according to the rules, with comparatively few exceptions. The temptation to help the "risk" on his way to the grave from which, in any case, he could not be far distant, must have been fierce at times. The Insurance Commissioner, in his report for 1880 , speaks of " one atrocious murder" with which " the criminal records of this Commonwealth are stained." No doubt he refers to the case of Joseph Raber, an old pauper of Lebanon County. This man's life was made the subject of these gambling insurances to the extent of tens of thousands of dollars. His life was too prolonged to suit the gamblers, and some of them found themselves face to face with ruin. Five of them-at least fiveentered into a conspiracy to murder him. The old man was sacrificed to their greed; and the five men were afterwards convicted and hanged. The account as between the murderers and the Commonwealth was balanced; but, as between the Commonwealth and the graveyard concerns, there were six lives lost and nothing to show for them. Next to this, the most shocking case referred to by the Insurance Commissioner is that of a villager upon whom no less than three hundred thousand dollars had been wagered. He died in a bar-room. It is not stated that any of the people interested in the insur- 


\section{Company Frauds}

ance were present at the time, much less is it suggested that he drank himself to death at their instigation and at their expense. It is stated, however, that the doctor who attended him at the last "was offered a bribe of five hundred dollars to certify that his patient was a good risk after he was cold in death." The conclusion that I have come to as to this case is that the parties who were to receive this three hundred thousand dollars, too careful of themselves to stab or shoot their victim, took advantage of his appetite for strong drink to give him the means of suicide. They murdered him for money as clearly as though they had shot him in order to take his purse.

In the newspapers of that time are records of many arrests for conspiracy to insure parties who, even under this crazy system, were regarded as uninsurable-people who, like the old toper mentioned above, were either dead or at their last gasp. The fact that some of these parties were arrested more than once for the same offence, taken in conjunction with the nature of a number of the cases, is strong presumptive evidence that a system of swindling the swindlers arose and was rapidly growing and reaching perfection when the crash came.

And all this loss, crime, and social demoralisation flowing from a merely supposed defect in the law, in conjunction with an uneducated public conscience in relation to matters of insurance! The people of Pennsylvania did not know that they were under the protection of a law given to them two years before that great day when, in their chief city, the delegates of the Colonies met and signed that Declaration which was the embodiment of the loftiest political morality of the time and has remained the touchstone of liberty ever since. How could they know that a musty old statute of the hated and discarded George III., commonly quoted as the law of insurable interest, bulwarked them against a flood of insane and wicked gambling, and that even a popular belief that that statute was no longer in force would loose that flood upon them ? The vast majority 
of the people stood free from this vice, and the way both public press and public officials attacked it proved that the Commonwealth was sound on the question. It was not a lack of morality that caused the trouble, but a lack of knowledge, or a lack of intelligent attention at the proper time. The public conscience was sound, but it was not properly informed. Insurance is not to blame because people love to gamble and will gamble in human life if the opportunity offers. But the people suffer when insurance is so abused; and, when that occurs, the people have none to blame but themselves. 


\section{CHAPTER XVIII}

\section{COMPANY FRAUDS-Concluded}

The Assessment Endowment Craze in Massachusetts-Defect in Law and what it Led to-Wild-cat Schemes Rob and Demoralise a Community-Many of the Working Poor among the Victims-Investigation and what it Revealed-Responsibility of the Legislature and of the People.

(6

I $T$ is doubtful if, since the famous South Sea Bubble, such a gambling mania has seized an intelligent people as that developed in the spread of the assessment endowment and its natural and legitimate offspring, the bond investment insanity." Thus speaks Mr. George S. Merrill, the Insurance Commissioner of Massachusetts, in his annual report for 1890 . He rather exaggerates the importance of the calamity,-as is natural, for he was like a life-saver in a fire or wreck, and the awfulness of the events impressed him deeply. There have been a number of such crazes in different parts of the world, and arising from various causes. But the outbreak referred to in the foregoing words of the Massachusetts Commissioner is still one of the most notable in history. For this reason, and also because of its recentness and of the peculiar circumstances attending it, we should study it as well as we can in the brief space that can be given to it.

In order that the account to be given of the ravages of this gambling mania may be understood, I ask the reader's attention to a few words-as few as I can make them-of technical and historical discussion. In previous chapters it has been shown that, under what is known as the assessment system- 
" pass-the-hat system," it is called by those who can afford to treat it with levity-insurance is often carried on upon a basis of promises to pay as losses make payments necessary, instead of on the basis of cash contributed and funded in advance of losses.

Now " endowments " have become a recognised part of life insurance. The nature of the endowment contract is this:-The contract is for a fixed period, say twenty years. During that time, or a part of it, the insured contributes certain sums at stated intervals. In return, his life is insured during the twentyyear period-that is, if he dies, his heirs receive the amount named on the face of the policy, less any deductions or plus any profits that may have been agreed upon. At the end of the twenty years, if the insured survives, he himself receives the capital sum. This, it will be seen, combines two contracts in one. One is of the nature of true insurance-which, as stated at the very beginning of the book, is the distribution of loss and nothing else-and the other of the nature of savings. These are two radically different things. In practice, and among people who wish only to count gains and losses, insurauce and savings may be combined without making much difference to anybody. But, in thinking-which, after all, is the first thing of importance in these matters-the essential difference between the two must be kept in mind.

Now, before we proceed, and reverting to the assessment idea, let me remind the reader that, with half a chance, schemers will form mutual benefit societies for any and every purpose. "What will it carry?" said the political candidate, referring to the proposed new railroad in his constituency; " it 'll carry me into the Legislature." On this principle does the gentle swindler in assessmentism proceed. "What will the association insure?" he says; "it 'll insure me a good living while it lasts." Now, here we have two things not truly of an insurance nature, but related to insurance as growing out of it-assessment and endowment. For a long time, 
they were kept apart. We can find the union of them in some of the old friendly societies of England, as well as in some steady-going assessment concerns in the United States. But, for all practical purposes, the joining of them began with, or rather, gave rise to, the outbreak of which we have to treat.

The inventor of the assessment endowment system, like other great inventors, probably did not foresee what would result from his scheme. The name of this great malefactor of the human race-I suppose that "malefactor" is as grammatical in this connection as "benefactor," though I cannot quote authority for its use-is lost to history. But he had successors and emulators in many places. Among them was a minor but more daring genius, who shortened the term of the assessment endowment contract while retaining the amount of it at a good figure. Theoretically, the assessment endowment proposition assumed this form: The member agrees to pay small sums as assessed from time to time, and, at the end of the endowment period, he shall receive the sum of the endowment, if the assessments made upon the members for his benefit yield a sufficient amount. The latter part of the arrangement, that including and following the word "if," was not strongly insisted upon in the work of drumming up members, but it was faithfully put in the contract, where it could be referred to, if deemed necessary. Moreover, it was usually represented that the assessments, according to the "expectation"-that being a word of highly technical character in life insurance, and likely to give great confidence as suggesting life tables, calculations of average, and so on-would be for two or two dollars and fifty cents each, and not more than eighteen a year.

So, the scheme as presented to the everyday person by the everyday touter was: You pay three hundred dollars in small assessments extending over seven years, and, at the end of that period, you receive one thousand dollars, with which 
you can go into business and make yourself a millionaire just as easy-! The concerns that offered these inducements were, in form, secret beneficial societies, with subordinate lodges, grand lodges, and supreme lodge. The association might have only a few hundred members, and all within a radius of a few miles, but it had all the machinery-nominally-of a great secret society, and its chief officers were known as "supreme" chief, or counsellor, or chaplain, or what not. This is what gave rise to the constant contemptuous reference in the literature of this subject to the acts and words of the "supremes."

Even the wild scheme thus explained, with its fantastic trappings, could hardly have raised a furore in any community, even one so favourably positioned as a working-ground for the financial gambler as was the Massachusetts of the late eighties. But some Yankee genius gave the scheme the last necessary touch of "slickness" and rapidity, when he invented the "numerical" attachment. With this final development, we have the bond investment scheme. The reasoning upon which this scheme was based was this: Here we have many people formed into an association and paying small sums for the purpose of giving each one an endowment at the end of a given term. Why keep all that money locked up for so long ? Why not pay each one as the necessary money is accumulated in the treasury? No sooner thought of than done. The certificates were numbered as issued, and every member was given his money as it came in;-at least, that was the theory. Under this system, a man might go in this week and, next week, realise the amount of his bond. A more frantic folly of sheer gambling with robbery as its almost inevitable accompaniment, it would be impossible to imagine. It does not appear that this scheme was ever better than an outlaw in Massachusetts; but the "supremes," where necessary, obtained some sort of acknowledgment in other States, and straightway swarmed into Massachusetts to join the carnival of gambling that went on, 
Thus, briefly studying its history, we find that the assessment endowment, bond investment scheme was evolved from insurance just as, we are told, the horse was evolved from that "little animal no bigger than a fox," of which the poet sings. And this scheme bore no more likeness to insurance than a horse does to its cenozoic progenitor. By the way, it may be said that, if this scheme was not insurance, it should not be dealt with in a work treating of insurance. My answer is twofold. In the first place, I find the subject treated by insurance journals, dealt with by Insurance Commissioners, and brought under investigation by insurance committees of legislatures; and so, in bringing it forward here, I only follow in the beaten track. In the second place, as this assessment endowment lunacy arose out of insurance, by misapplication of the insurance principle, it is most strictly in order to treat of it in a work the very object of which is to warn against the dangers arising from such misapplications.

The assessment endowment scheme worked along rather quietly for some years-the bond investment horror being still unthought of at that time. But, when the earlier certificates began to fall in, and people here and there were able actually to show the cold cash-strange that even when cash comes so close to us that we can handle it, we always speak of it as unfamiliar, "cold" - received in return for these assessments, why, that put a different face upon the matter. A man may spend forty years prospecting for gold; but if, at the end of that time, he strikes "pay dirt," all his friends will drop the business in which they happen to be engaged and go out, ready to pick up a gold mine in the course of an afternoon's walk over the hills. On that principle, the people who saw the money realised on an assessment endowment forgot that there were seven lean years of paying out between the taking out of the bond and realising upon it. They were of the kind that Tennyson invokes when he says: 


\section{But who shall so forecast the years \\ And find in loss a gain to match? \\ Or reach a hand thro' time to catch \\ The far-off interest of tears?}

The sight of the one thousand dollars blinded them to everything else-to the absurdity of the mathematical proposition involved, to their own payments meantime, and to the vicissitudes of fortune possible during seven lean years. The assessment endowment became quite fashionable in some places, and many men who ought to have known better, and who certainly, for the sake of their own reputation, should have meant better, gave it countenance. A whole volume might be written about this mania as it developed in different parts of the United States and elsewhere, but we shall probably understand better the nature of the thing and the reasons which made it what it was if we confine our study mainly to the place where its ravages were greatest - the State of Massachusetts.

First, it should be pointed out that Massachusetts was then, as it has almost always been, a most prosperous State. Its people were largely of that cultured, well-to-do, law-abiding, dominant class usually spoken of as "good" people; but still more largely of factory operatives and working people of various kinds, who earned pretty steady, but more or less scanty, wages, for tending the multitudinous machines which Yankee ingenuity and enterprise had set up, and has since greatly increased, in many towns large and small. There was also, naturally, a residuum of schemers of various kinds, who worked when forced by circumstances to do so, but who preferred to enjoy a good living with other people's money. Thirty years or so before the time of which we now speak, Massachusetts had been the scene of a wild gambling craze growing out of the "loan societies" movement, a scheme based upon a belief in the innocent Yankee mind that money could be loaned at a high rate of interest and borrowed at a low 
rate of interest, and both borrower and lender make money on the transaction. Later on, Boston, the chief city of Massachusetts and the birthplace and early home of that great philosopher of thrift, Benjamin Franklin, had been the scene of the exploits of one Mrs. Howe, who had opened a bank the depositors of which were paid fabulous rates of interest, until the promoter of the scheme was interfered with by busybodies from the police station. The people of the Old Bay State were now ready for almost any hook that was baited with some gaudy financial scheme.

In this case, as in that of the graveyard operators whose history we have just considered, the difficulty arose, not alone through the readiness of the people to be choused, a characteristic by no means peculiar to any one time, country, or class, but through an unfortunate failure of the law to protect them at the proper time and in the proper way.

About 1887, there came into Massachusetts an institution having its headquarters in Indiana and known as "The Order of the Iron Hall." I may be wrong, but I believe that much of the mischief which it is the business of this chapter to recount was due to that name. To the mind of the fairly welleducated person-the average legislator, for instance,-it had in it a suggestion of solidity, combined with the highmindedness and mysticism of mediæval chivalry at its best. The Iron Hall-to give it its popular name-was an assessment endowment concern which offered one thousand dollars in seven years, "if-"; together with sick-benefits meantime, - the amount of them to be deducted from the endowment at the maturity of the bond-and return to the estate of the member of all payments made, in case of his death during the currency of the contract. In $1887, \mathrm{Mr}$. John $\mathrm{N}$. Tarbox, then Insurance Commissioner for Massachusetts, called the attention of the law officers of the State to the operations of this concern, believing them to be without the warrant of law. The opinion of the 
Attorney-General of the State was that the Iron Hall was doing an illegal business. No doubt, the order would have been at once excluded from the Commonwealth, had it not asked for time to lay its case before the Legislature with a view to the amendment of the law governing the case. This was granted. When the question came before the Legislature, Mr. Merrill, who had, meantime, succeeded to the office of Insurance Commissioner made vacant by the death of Mr. Tarbox, made a strong plea against any legislative concessions in favour of the Iron Hall or any similar concern. He entered into elaborate calculations to show that the scheme was mathematically unsound, and must result in disaster to those who embarked their money in it. He reminded the law-makers of previous gambling follies through which the people of Massachusetts had been heavy losers. He also went into the arguments presented by the Iron Hall people, and showed that there was no soundness in any of them, while the record of the concern elsewhere was not such as to justify the Legislature in commending it to the people. But the applicants had been wise enough to broaden their plea. Instead of merely asking a charter for themselves, they presented an omnibus bill authorising the formation of assessment endowment corporations practically on the Iron Hall plan, and permitting those of other States-remember that the Iron Hall was a Hoosier-then transacting business in Massachusetts to continue doing so. The pressure of popular opinion, many people being already members of the order, together with the smooth argument of able and highly-paid counsel, overcame opposition, and the law was amended as requested. The Insurance Commissioner, in a subsequent report, spoke of this as "the unfortunate statute of two years ago." In this case, as in so many others, the difficulty was not so much what could be done by direct authority of the law, but what was done behind the law when that law could be used as a cloak for conspiracy to defraud. And, these things 


\section{Company Frauds}

once begun, the law may afford no check because, while the action complained of may be clearly in violation of the spirit of the law, there may be a sufficient compliance with the letter of it to make a fairly presentable case on behalf of the malefactor, even if a charge is laid against him.

Looking at it here, the utter folly of trusting to such a scheme as this assessment endowment, bond investment scheme is apparent at a glance to everybody. What, then, were the arguments used to convince people that the "supremes" had an alchemy for making money out of nothing in this fashion? There were, in the main, two points. The first was that many members would lapse, leaving what they had paid in to be divided among those who kept up their payments. This was the old tontine idea, an essentially immoral scheme, and, as the Commissioner showed over and over again, one that was under the reprobation not merely of the spirit, but of the plain letter of the Massachusetts law relating to insurance policies. But, whether these bond and endowment certificates were insurance policies within the meaning of the law, was not quite so clear. The other point was that new members would so swell the funds that payment of all liabilities would be easy. In proof of this, simple calculations were made to show enormous sums, which so stunned the understanding, while captivating the imagination, that people were delighted to go in and share these fabulous riches. To those who were clever enough to see that as the funds increased the liabilities increased in greater ratio, the argument was suggested rather than presented that those who would not be paid were those who came in last, whereas, at that particular time, the particular person addressed had a chance to "get in on the ground floor."

In this business, as in so many others, that favourite motto of the Evil One, "It will last my time," was the rallying cry that brought in thousands. But, to cover all lapses in argument, there were, first, the names of those who had actually 
received one thousand dollars in return for about three hundred dollars, and, second, and even more important, a sunburst of talk about " charity," "fraternity," " mutual love and help," and "the Fatherhood of God and the Brotherhood of Man."

The same radiant prospects that led schemers in Pennsylvania to organise graveyard concerns, opened out to those in Massachusetts who found themselves able to set at work these new patent contrivances for making money out of nothing. The genius for building castles in Spain for others, while providing a solid stone mansion at home for yourself, was exercised to the utmost. As the law was, in fact, for the benefit of the Iron Hall, it remained untouched as affecting corporations from other States. But the Legislature conceded a point in I 890 by declaring against the incorporation of other similar societies in Massachusetts itself. The result was that far more foreign than native concerns were organised; but Massachusetts was the centre of the working system. In vain did the Insurance Commissioner plead with the Legislature to avert the flood of disaster which was piling up behind unwise laws. In vain did solid business men and philanthropists seek to prevent those among the poorer classes in whom they were interested from wasting their money in these reckless and wicked speculations. When the Boards of Trade of Boston and other places sent delegates to urge the committee of the Legislature having the matter in charge to put a stop to this gambling, the attorneys of the societies, with all the effrontery of their kind, crossquestioned, bullied, and insulted the men who had ventured thus to disturb the game, and actually sought to make capital out of the fact that these merchants, who simply desired to point out to the people's representatives obvious considerations of public interest, were unable to follow without confusion or hesitation, catch-questions involving complex calculations which were part of the "lay-out" with which the fakirs de- 
ceived and robbed their victims. It was sneeringly suggested that these business men were actuated by the lowest motives. It was hinted that their opposition was due to the fact that money paid to these societies would do the business men less good than if spent for goods made or sold by them. And, when other respectable people, warned by the treatment the representatives of the Boards of Trade had received, remained away from the Legislature and allowed events to take their course, the attorneys for the speculative confraternity urged the absence of protest from large classes of responsible men as a reason why the privileges of the endowment and bond concerns should not be interfered with. Even after it had become more than manifest that their continuance only meant a wider area of ruin and disaster, this opposition to amendment of the law was continued.

The form of organisation adopted by these concerns, as already stated, was modelled on that of the great secret fraternal orders. The Iron Hall and all its brood was early repudiated by the central organisation representing the best of these great and useful societies. But that only made the "supremes" more anxious to conform their organisations to those which stood so high in public estimation. This secret society form, as against the ordinary insurance company form, lent itself to methods of propaganda that were far speedier than the mere hand-to-hand canvassing of the insurance company. A "supreme" visiting a town to look for business, did not come in the guise of an agent or commercial traveller. He was heralded by puffery in the newspapers and by flaming announcements on the fences, and his "new system of finance" was lauded as the one thing necessary to the happiness of downtrodden humanity. When he came, he was met by a brass band, with, perhaps, a delegation of " influential citizens," and escorted to his hotel with all the éclat of a popular hero. Instead of waiting upon the people one by one and presenting the claims of 
his "system" as one having something to sell, he called a public meeting, and went to the hall the central figure of a torch-light procession, with the inevitable brass band in advance. The hall filled, he treated the gaping crowd to a flamboyant oration, in which he promised that all should be rich, and backed his promises with calculations which nobody understood but which many accepted because they desired to be convinced. The final act was to form a lodge of the order or at least to go through the preliminary stage by getting the names of those ready to join: The matter would then be left in the hands of a local man, and the "supreme" would proceed to the next town to repeat the operation. This kind of thing, alternated with current reports that this, that, or the other citizen had actually received the amount of his bond or his endowment, naturally brought about a pandemonium of excitement, which prepared the lambs for the operation of fleecing and brought them in droves to give their little all into the keeping of these vulgar swindlers.

As in all these gambling manias, the game soon grew too slow for some of the more excitable and venturesome of the players. To meet the demands of this class, the bond investment and other inventions were sought out. More and more striking inducements were offered to tempt the unfortunate victims to part with their money. The term of endowment was shortened to five years, to three years, to eighteen months, with corresponding reductions in amount, of course. For, dealing with a poor class of people, as they did, the assessments could not be increased by even the cleverest of the "supremes." At length came orders with an offer to take monthly assessments of two dollars each and pay one hundred dollars at the end of one year. One hundred dollars for twenty-four dollars! What better could one ask than that? But there was still better; for the officers of one of these orders, the "Royal Ark," with hope and honesty shining in 
every line of their advertisement, not only offered to pay one hundred dollars for twenty-four dollars, but agreed that what was left of the contributions after paying that amount to every member should be "carried to the reserve fund." The Insurance Commissioner caustically suggested, while the concern was still in the heyday of prosperity, that the name "Royal Ark" "was surely not chosen from the fact that, like its great prototype, only a few will be taken in."

Not only did those who were to be the victims of this delusion become more excited and less amenable to reason as time went on, but those who thought they were managing these bogus orders lost their heads also. The law, wide though it was, soon proved far too narrow for their operations. From scheming and overreaching, they soon descended into downright crime. To induce people to place their money on such a wild venture was of itself an immoral act for which these parties would have been held strictly to account under just laws. But this was only the first step, in many cases. The money taken in was supposed to be held, of course, to pay endowments as the certificates matured. But the presence of so much money in a treasury completely under their control was too much altogether for the tenuous moral fibre of many of the officers. Under one excuse or another, the treasuries were looted. In the first place, the "supremes" voted themselves salaries which would excite laughter were it not that the people who were robbed included the poorest of the industrial population. A concern of 12,484 members, which did not live for even the one year fixed for the maturity of its certificates, had expenses of about $\$ 120,000$ most of which went in salaries. That is, each member was taxed an average of nearly \$ro just to carry on the work of the society. In another, a president who took office only three months before the institution of which he was head went into bankruptcy, received about $\$ 7800$ for his services, or at the rate of $\$ 3 \mathrm{I}$, 200 a year. 
In another, six officers, who held their places for fourteen months, received about $\$ 64,000$, or an average salary for these parties of about $\$ 7500$ a year. And this for an annual endowment concern with less than 25,000 members, all told. In the case of an institution known as the "Golden Lion," with 12,000 members, when its officers were interrogated in court, princely salaries were shown to have been paid. One man, being asked what office he had held in the order, said he had been Supreme Chaplain, his salary being $\$ 7500$ a year. This naturally led to questions as to the services which were expected to balance so fine a stipend. His duties, the man explained, were to open the Supreme session with prayer. Was he a clergyman ? was, naturally, the next question. No, he had been a clerk in a store at $\$ 15$ a week. The contrast between his previous condition and that he enjoyed as a "supreme" is emphasised by the Commissioner, who points out that, as the Supreme session of the "Golden Lion" was held but once in two years, this very fortunate person was in receipt of $\$ 5$, 000 for a single prayer. It only needed to be shown that the Supreme Lodge never had a session at all to make the absurdity complete; but, unfortunately, in the imperfection of all things human-even human absurdity-that perfecting fact is not set forth in the official documents. It may be, therefore, that this holy clerk actually did give a return for his salary by offering the prayer agreed upon. It is only just to him and his associates to say, also, that, whereas a good many of the "supremes" took every dollar in the treasuries under their control, these parties left no less than $\$ 200$, 000 to be returned to the members who had made their payments faithfully.

A favourite scheme for transferring money to the pockets of the officers was for these officers to vote themselves "donations." In one concern, the men in control, whose salaries ranged from $\$ 100$ to $\$ 750$ a month and travelling expenses, voted themselves considerable sums for " past" services, and, 


\section{Company Frauds}

at the next meeting, still other sums for "previous" services. When the concern went into liquidation, it fell into the hands of a man who had been defrauding another bond investment order; and it is not to be wondered at that when an honest man was, at length, chosen to wind up the order's affairs, he found no assets whatever. In one case the donations thus voted to themselves by the officers-in cold blood, be it remembered, and without even a shadow of justification-amounted to an average of $\$ 2000$ for each. How modest, by comparison, was the "supreme" who, on his silver wedding, had himself presented with $\$ 200$ worth of jewellery which was paid for out of the funds of the concern over which he presided. "Travelling expenses" were a notable source of revenue to the plunderers. These, as may be imagined, were arranged upon no niggard scale. In one case a fine span of horses and all the "fixings" for a genteel turnout were placed by one of the "supremes" at his own disposal, and charged to "travelling expenses."

The very honesty of these concerns, if there was a shred of honesty in them at all, was turned into dishonesty. The nominal object of the organisation was to pay to certificate-holders the benefits agreed upon, and to pay them in the order of their certificates. On this basis, of course, those who joined first were certain of their money, if a sufficient number of others joined later and the money was not stolen by the "supremes." Thus, it was an easy matter, at the beginning of, say, a one-year endowment order, to issue the first certificates to the promoter and his friends. These certificates would be faithfully paid, but the honesty of the officers might grow weak when it came to the handling of funds for the payment of others. This idea of choosing those to whom the money was to be paid was acted upon in various ways, but with one intention and one resultthe payment to the conscienceless robbers who managed many of these orders of all the money in the treasury. In one, for instance, the officers, finding $\$ 30,000$ in the treasury which they 
hated to leave behind, though they had sold out to another gang,--and that selling-out system is a point to be explained in a moment,-formed a merely fictitious lodge of three hundred members, - fictitious names too, - issued certificates to these imaginary parties and dated them back to make the transaction look regular, then paid the real money to their real selves, and left their successors an empty treasury. But the haste with which these things were done and the appalling effrontery of these robbers were shown by the fact that, when the official receiver took over the office, he found these three hundred certificates in a safe, all in a bundle and not even folded. In a further half-hearted and clumsy attempt to conceal this fraud, a new cash-book had been written, but enough of the old one was found to expose the rascality. In another order, a similar robbery was, evidently, in contemplation. There was, in connection with this order, a mysterious subordinate lodge, with the membership limited to a few, but including the "supremes" and their immediate friends, each holding many certificatessome of them held hundreds. Another fraud in fact which was not necessarily a fraud in form was the payment of commissions for bringing in members. There is no reason, of course, why an endowment concern should not pay a commission to agents, if the best insurance companies may do so. But when a concern was made to pay to the chief promoter a commission on all business, no matter by whom procured, the payment became a mere levy and not a recompense for services. This might easily appear when, as in one order, the books showed that this fortunate officer, in commissions and other forms of emolument, received about $\$ 70,000$ a year. The printing, too, was a favourite means of "whipping the devil round the stump." One of the officers would be appointed "printer to the order," and all supplies would be bought from him, presumably at prices intended to make it advisable for him to remain in office. The office of printer was generally engrossed by one who held 


\section{Company Frauds}

other positions in the order. Therefore it is not easy to say what this particular method of robbery cost the members of any society.

These " supremes," like other Jacks in office, soon came to regard themselves as identical with the order they were supposed to manage for the benefit of the members. Their places yielded such splendid returns that they were worth, in fact, a great deal of money. It was not long before deals were made for the selling out of one order or another to those who preferred the certainty of a going concern to the chances of establishing one for themselves. As these orders were "purely mutual," it would naturally be supposed that only by the consent of the members as declared in a general meeting, properly called, could this selling out be effected; particularly as, under the law, the rules of every order had to be submitted to the Insurance Commissioner for approval before they could be brought into effect-and the Insurance Commissioner of Massachusetts could be depended upon to "view them with a critic's eye," and not a very friendly critic at that. The case of selling out, then, would look like a problem for the fine steering of the political worker, to bring a majority of the members into accord in favour of the proposition. But such methods were far too slow and uncertain for the enterprising thieves who had in hand the job of looting the treasury of an endowment order. Care was taken that the organisation was on such a basis that the purchaser of the offices might be sure of having the goods delivered to him. The Commissioner explains how this was done in one case:

When the officers of the Annual Friend originally brought their constitution and by-laws to the Insurance Department for examination, there was therein no provision of representatives. The Department dedeclined to approve the papers in that form. The incorporators went away and amended them, inserting a provision that every subordinate lodge of one hundred members should have one representative in the 
supreme body and an additional representative for every additional two hundred members. The by-laws were approved. The charter secured, the seven incorporators immediately walked down to the supreme office and issued a call, giving seven days' notice, of a meeting of the supreme body. At this session, they struck out "subordinate lodge" and put in "grand lodge," and they struck out "one hundred members" and put in "ten thousand," and, as they never had ten thousand members in one jurisdiction, they could not have a grand lodge, and thus they utterly destroyed the provision that permitted any member to come in. By this trick, the little group were able to sell out when the time came.

No doubt, many of these gentry actually believed that they had a perfect right to sell out their positions, just as they would have a right to sell anything they owned. And it is not easy to say, considering how far astray the law had gone, that they would be wholly wrong in reaching such a conclusion. But fine points of ethics are hardly in order in the consideration of these affairs, and evidently they entered not at all into the calculations of the "supremes" in the dickers and deals they made to enrich themselves at the expense of the unfortunates who trusted them. In one small order, which had a total membership of 2600 , the officers sold out for $\$ 8000$. They received $\$ 3000$ in cash, and the balance in the note of hand of the purchasers. When the promise came due the new officers coolly appropriated $\$ 5000$ of the funds of the order to pay it. This was only one of the sums that the newcomers used for their own purposes, apparently without any effort to mask their stealing with even such a flimsy pretext as "past services" or " travelling expenses." The "Friendly Aid Society"-how sweetly simple a name-was sold out by its officers for $\$ 27, \infty 00$, and the incoming crowd, who were able to keep the business out of the hands of the receiver for only thirteen weeks after their advent in office, managed to get back their money and almost \$10,000 besides. "The books of account are in a sadly confused condition, almost impossible of being satisfactorily adjusted," says 
the Commissioner. No wonder. However, about $\$ 34,000$ was recovered. Here is a curious case of "diamond cut diamond," as given by the Commissioner in speaking of one of these orders:

The former officers made an attempt to sell out for the sum of $\$ 50,000$. This money the purchasers borrowed from the Order of the Rising Sun, a foreign endowment corporation. The Insurance Commissioner refused to recognise the legal standing of the newly-chosen officers, and declined to allow them to draw any money from the funds in the hands of the Treasurer of the Commonwealth. The former officers again assumed control of the corporation, and refused afterwards to turn it over to the men who claimed to have purchased it, leaving the latter minus both the corporation and the cash.

The officers of the Rising Sun were afterwards indicted for embezzlement of the $\$ 50,000$, and three of them, who pleaded guilty, were sent to State prison for five years.

As might be expected, many crimes were committed in the course of the carnival of gambling speculation which attended the operations of these orders. Besides those already mentioned, a number of men were sent to State prison, while others only escaped a like fate by flight. When we-consider these facts, we see that those who were robbed were not the only victims of the craze; and, perhaps, though most numerous, they were not most to be pitied. The "supremes," some of whom had had fair reputations until caught in the swirl of the speculative maelstrom, were themselves the worst victims-not alone those who were sent to prison, but those who, while escaping that fate, found their businesses lost, their habits of industry, such as they may have been, broken, and their moral fibre weakened by the speculative fever from which they had suffered.

But the fate of the other victims was pitiful enough. Strange as it may seem, many business men of good standing staked their money with the endowment fakirs. Upon these, little 
pity need be wasted. They must have known that they could succeed in such a speculation only by robbing others; and, if they lost, it served them right. Besides, whatever money they lost, on the whole, they could afford to lose. But these were the smallest class of revellers in this saturnalia of fraud. The majority of those who trusted the "supremes" with their good money were operatives in the mills and other wage-earners of small and even precarious income. These people, as a rule, were ignorant, and many were innocent of any design of injuring others to enrich themselves. They saw people receive $\$ 1000$ in return for $\$ 300$, or $\$ 100$ in exchange for $\$ 24$, and they merely desired similar benefits, accepting as gospel the stories told about this " new system of finance," the miracles worked by the " principle of co-operation," and the efficacy of " new blood" in making impossible speculations the most remunerative things in the world. They were too ignorant to even ask questions, and too unsuspecting to believe that the laws of the Commonwealth could be used to bolster up a vulgar fraud. Having once invested, it was necessary to persist. This was particularly true of the poorest of these victims-those who could least afford to lose the mite they had first laid upon the gamblers' board. The tales of woe told by some of these unfortunates, who saw, not merely their rainbow prospects of wealth dissolve, but the hard savings of months or years taken away, were heart-rending. The unfortunate Commissioner of Insurance, who, though he had done all man could do to prevent the inception and check the growth of the evil, was, nevertheless, the one to whom many turned in their trouble, tells how, during the summer when the failures of these concerns were most numerous, he felt it his duty to forego his usual holiday, and remain in his office to receive these ruined gamblers. Not that he could help them, but they thought he could. No doubt they felt better satisfied to have his kindly assurance that, if anything could be saved for them out of the wreck, that would be 
done, rather than to find the office closed or to be received by a clerk whose response to their inquiries would be coldly official. To the prosperous business man or the man who lived by his wits, it was a matter of small concern to drop a few dollars or even a few hundred dollars in such a game as this. But for the underpaid factory hand it meant a still scantier table, shoeless feet for the little ones, a lack of medicine, it might be, to heal or save the sick at home-deprivation in one way or another of the actual necessaries of life. And, of course, in this, as in other outbreaks of crime due to insurance, there was general and widespread demoralisation. Hours that should have been spent in earning wages were thrown away in looking after these crazy speculations, or trying to save from the wreck when it occurred what had been so foolishly ventured. On this point, the Commissioner of Insurance, in 1892, speaking with all the greater impressiveness because at that time the folly of the scheme was being demonstrated to even the most hopeful, by the failure on every hand of endowment orders, said:

Some of you have not failed to see what a spirit of unrest and gambling these corporations have created among the working people. We hold mass meetings in Boston, at which Governors and our chief citizens are present, to condemn with warm words the Louisiana lottery. From my experience in the Insurance Department the past eight months, I believe that the Commonwealth of Massachusetts had better, four years ago, have passed a statute legalising the Louisiana lottery and authorising it to open a branch office in the front corner of the Old South Church or here under this [State House] dome than to have enacted the statute that allowed this class of corporations to do business, with the wreck and ruin which has already come and which, in a large measure, is to follow, if this business goes on as at present.

In the following year, 1893 , the Commissioner was able to put a headline in his report, "Exit the Endowments," and to say: 
With the passage of the act to wind up the affairs of the eight remaining Massachusetts endowment orders, the last official chapter in the history of this extraordinary craze will be written, and it only remains for the receivers to be selected and for these officers, with those previously appointed by decree of the courts, to close up the accounts and distribute the remaining assets. The compilations of their condition disappear from the Insurance Report, and their returns no longer disfigure the records of the Department.

This result, it should be clearly understood, was not due to any enactment of the Legislature interfering in any way with the operations of the concerns that had been chartered. Though every effort was made to bring about the passing of a law which should summarily stop the speculations, the Legislature could not be induced to go further than to declare, as it did in I 890 , three years after the passing of the " unfortunate statute," that no further charters for concerns of the assessment endowment character should be granted. The gambling went on for more than two years after that-it went on until its victims were so greatly multiplied and the danger of having anything to do with bonds or endowments so clearly manifest to the people that the "supremes," in spite of all their efforts, could not get in enough money to make the game a paying one.

From the court's report of 1893 , it appears that there were, in all, 56 Massachusetts corporations of this class. How many outside concerns operated in the Commonwealth does not appear. The members of these 56 concerns numbered about 364,000 , in respect of whom obligations were undertaken by these wild-cats aggregating no less than $\$ 120,000,000$ - that is, it would have taken that enormous sum to pay all the certificates issued. Of course, no such sum was collected from members. The total amount paid in by the victims was about $\$ 12,500,000$, which is little enough, as compared with the obligations, even if we make a liberal allowance for lapses, but is an enormous sum to have taken, in the main, from factory 


\section{Company Frauds}

hands and other wage workers. At the time of the issue of the report, the sum of $\$ 3,500,000$ remained in the treasuries of these broken concerns to be distributed amongst those who could establish claims. The work of winding up so many orders, most of them, as the Commissioner says, "scarred and marred and blistered all over with fraud and cheating and robbery and embezzlement and corruption," with their records missing or so badly kept as to be little, if any, better than none, with their officers condemned criminals or fugitives from justice, was no easy or inexpensive matter. From the money rescued from the wreck, a considerable sum must be deducted for expense of winding up and distribution. In many cases, no doubt, all or even more than all that was left was needed to pay these expenses, and thus some of the victims must have lost every cent they put into the game. With $\$ 3,500$, 000 remaining in the hands of the receivers out of $\$ 12,500$, 000 collected, we have $\$ 9,000$, 000 still to be accounted for. Of this sum, the holders of the early certificates, numbering less than nine per cent. of the members, received $\$ 3,000,000$. Among these, of course, were the "supremes" and their friends. It seems not unfair to say that these alone received anything on this account. If an outsider received anything, it was by mistake, or in order to use him as an advertisement. Then, $\$ 2,000$, 000 was paid in sick-benefits. We may be sure that, of this amount also, a great deal was paid fraudulently and went, in some way, to benefit the "supremes." Then, $\$ 4,000,000$ went in expenses. We can see by the instances already given that, of this, a very large proportion was simply stolen. In any case, the scheme itself being a delusive one, however honestly it may have been carried on by some of the gamblers here or there, not a cent of the money spent in these operations can be said to have been of any benefit whatever to those who paid it in. If not stolen, it was wasted. The clear loss to the people of Massachusetts was, certainly, not less than $\$ 8,000,000$. This was through the 
operations of those concerns chartered by the Commonwealth. There was, besides, an uncountable amount lavished on the fakirs and schemers who carried on their operations within the State, but under foreign charter. Practically all this loss took place within a period of less than four years, or an average of $\$ 2,000,000$ a year on the Massachusetts corporations alone. Such waste on the part of the wage-earning class was enough, not merely to keep the losers in poverty and debt for years, but it was enough to check business, to make all the difference between good times and bad times for the whole Commonwealth.

Though I have given so much space to what was done in Massachusetts by these concerns, it must not be supposed that the evil was confined to that Commonwealth. It probably was worse there than in any other community owing to the nature of its population and to the standing unfortunately given to endowment orders by the amendment in the State law designed to admit the Iron Hall; and this makes Massachusetts naturally the typical case of this particular epidemic. Moreover, the splendid fight made against this delusion and fraud by Insurance Commissioner Merrill, and the full account of its progress and decay given in his reports, make it comparatively easy to trace its history in the territory under his jurisdiction. From the record as we find it in the insurance press and other current literature of the day, it is evident that Mr. Merrill was looked to to supply the ammunition with which to fight this enemy wherever it appeared. When attempts were made in various Legislatures to gain recognition under the law for local or foreign endowment orders, it was to the reports of Commissioner Merrill that the opponents of such concessions turned for arguments to sustain their contentions, and upon his statements of the experience in Massachusetts that they relied to show the gambling character of the speculation. There was probably not a State in the Union into which the assessment endowment orders did not penetrate with their flamboyant promises. They 


\section{Company Frauds}

crossed the border into Canada also, and every Province of the Dominion was left the poorer for their operations. In that country, both the Provincial Legislature of Ontario and the Federal Parliament of the Dominion were successively appealed to by the "supremes," but in vain. Fears were entertained that in the succeeding Dominion general election the endowment orders would unite to work the political ruin of those representatives of the people who had ventured to oppose their claims. Before the Government appealed to the country, however, the endowment swindle was a thing of the past, and the officers and agents of various broken societies who remained in the country were glad enough to avoid a course likely to bring them into focus of the public gaze.

Just what loss this fraud involved on the whole, it would be almost impossible to say. The Insurance Commissioner of Massachusetts estimates that " a round million of people" in the United States were taken in. If they contributed only in the same proportion as the average certificate-holder of the Commonwealth, the amount thrown into the leaky treasuries of these preposterous orders was not less than $\$ 40,000,000$. Fully three quarters of this sum must have been wasted. To show how great a hole this made in the savings of the people in some cases, I quote two facts from the report of the Insurance Commissioner for New Hampshire for 1893 . The first is that about three hundred endowment orders were at work, or were preparing to go to work, in that State when the system was broken by the enforcement of a statute passed in I89I specially to meet this evil. The second is that, as the Commissioner was informed, in one town with a population not exceeding seven thousand, over $\$ 4000$ was contributed to one endowment association alone and that largely by the labouring class. Such facts give us some idea of the fierceness with which this epidemic of greed and folly raged in many parts of the United States.

To this sort of thing any community is liable, should some 
crank evolve a " new system of finance," or some sharper discover a new gaud with which to deck his gambling layout and which by some hocus-pocus of language can be called "insurance." These parties, however, could not of themselves overrun a community, bewitch the people, and bedevil business. Only when they are able to get from the Legislature a diploma or charter, or paper recognition of some kind, can they make really rapid progress. But this case and all the others to which attention is drawn in this work make it clear that the members of the Legislature are not to be relied upon to do the sensible thing always. And for one Legislature to go wrong is to give the schemers a quasi standing not only in the community directly affected, but throughout the country, or, it may be, throughout the world. Should the pessimists of our day prove right, and imperialism depose democracy, the time may come when the authorities may be able to do their work alone, guided by the light of pure reason or high-minded desire for the public weal. But, at present, democracy is the law practically in all civilised countries, and, so long as this is the case, the Legislature can be guided, in the last resort, only by the allpervasive and all-powerful influence of public opinion. It was so in the case of Massachusetts and the assessment endowment orders. The legislators could not have relied upon their own common sense or knowledge; for, had they done so, they would have seen that the proposal submitted to them by the Order of the Iron Hall was, at its very best, a mere pitiable delusion.

Granting, for argument's sake, the honesty of those who presented it, any man following the calculation from the beginning, as it was the clear duty of legislators to do, must have seen that the promoters of the scheme were as much deceived as any poor crank who spends his feverish existence in the effort to increase power by increasing machinery or demonstrate perpetual motion. But if the legislators had any doubt about the matter, they had not far to go to have those doubts 


\section{Company Frauds}

resolved. To say nothing of the presumption of his disbelief in the scheme shown by the steps taken by Mr. Tarbox, there was the strong fight made against any recognition of the endowment orders by Mr. Merrill. That gentleman was the official whose special business it was to understand these matters with a view to informing the public and advising the Legislature. Had he hesitated at any time, or shown doubt on any point, there might have been some excuse for the legislator resorting to his own opinion. But not only was Mr. Merrill clear in his views, but he proved the soundness of those views by every argunent that could be applied. Statistically, logically, mathematically, and historically, and in the light of common sense, he considered the case, and proved that, however it was regarded, the scheme was an absurdity or a fraud.

Had Mr. Merrill even relied upon the manifest absurdity of his opponents' case and upon the presumed patriotism and good sense of the people's representatives, and for that reason kept quiet, there might yet have been some slight basis for that bad excuse which is said to be better than none for the course taken by the Legislature of Massachusetts. But he did not do anything of the kind. On the contrary, he went out of his wayit might almost be said that he exceeded the bounds of his official position-to make clear, beyond all controversy, the danger ahead, and to arouse both the people and their representatives to a sense of that danger. On the other side of the case, there were just two influences-unless we assume bribery, which I will not admit or even consider. The first of these was the oratory of able counsel retained by the schemers to plead their case. The Iron Hall people had the good judgment, from their point of view, to secure the services of the very best men in the Commonwealth, men who had not only the highest standing and greatest ability as lawyers, but the greatest influence among the people. What they said with so much skill had fifty times its own force because it came from them. The 
fact that this oratory had its effect is proof that legislators are human, after all, and that they can be swayed against even their own judgment, if you bring them under the influence of a forceful and able man. The other influence was public opinion. That public opinion, though, at the time, not great as a mass, was all one way. Here and there throughout the State were knots of men who had convinced themselves that this scheme was a good one, and, more or less plainly, that fact was made known to the representatives of the people. Real public interest and every other consideration which is supposed to influence legislation were cast aside, while oratory and vote-pressure carried the day. The schemers got the endorsement they sought.

It does not necessarily follow that this will be the result in every such case. The misstep made by Massachusetts is only another example proving that eternal vigilance is the price of safety. Had there been a strong, well-informed public opinion upon which to rely and to which to appeal, the very fact of its existence would have kept the Legislature on the right lines, and all trouble would have been avoided. But when the case passed beyond the Legislature and came before the ordinary mill hand or store clerk, in the form of an appeal to him to buy certificates, it was a vastly different case from that which went before the Legislature. The endowment scheme, as the representatives of the people saw it, was naked, and its deformity was plain to any who would look. True, its best features were made the most of and it was made as little ugly as possible by oratorical embellishments that were thrown about it, while its friends urged its acceptance. What the Legislature did was to give the thing a cloak of approval,- - very gauzy, it is true, and not intended by its donors to be used for deceit, but none the less a cloak. Thus apparelled, the endowment fake stalked forth boldly. Dickens, somewhere in his writings, pooh-pooks the idea that a liar cannot face the gaze of an honest man, and declares that, with any sort of excuse for its own existence, 


\section{Company Frauds}

mendacity will stare truth out of countenance. So it proved here. People engaged in any reasonable scheme of saving or insurance would never have dared to resort to such methods as did the "supremes" of these gambling concerns. At the risk of wasting valuable space, I venture to place before the reader just one of hundreds of the circulars that were issued. This is not chosen for its singularity; it is the first I came across in looking over the record. But there is a naiveté about this that makes it worthy of attention:

\section{AH THERE !}

INVESTIGATE THIS.

The

Boom Endowment Order,

Chartered in New Hampshire, April 20, I89I,

PAYS $\$ 100$

in one year, as follows:

$\$ 15$ at the End of 4 months, $\$ 25$ at the End of

8 months, $\$ 60$ at End of Year.

Best Plan in Existence.

$\$ 22$ is the greatest amount of cash a single certificate holder uses in carrying him through the year, because he uses his money over and over again. Ten certificates may therefore be carried at about the cost of four in any other endowment concern.

First Lodge to be started May 20.

BASEMENT NOW OPEN.

Organisers we want you-you want us.

Address for particulars, A-B - Supreme Secretary,

Massachusetts Headquarters, $\longrightarrow$, Mass.

"Uses his money over and over again"-there is the touch of a master. Note also, "Chartered in New Hampshire." When the scheme offering something for nothing or much for little was presented by the touter to the factory hand, it was with a preliminary flourish to the effect that the Legislature had given the thing its sanction, approval, endorsement, - this would not be allowed to fail of effect for lack of being strongly worded,- 
and, therefore, it must be all right. The party thus appealed to, knowing that the Legislature had, over and over again, made laws to protect the people against unsound schemes, would naturally make the law as passed the very basis of his estimate of the scheme. Bringing this in as a factor in the reasoning, he would naturally reach the conclusion that his money would be safe if invested with the "supremes." That being so, the loss he bought was not, in fairness, his own, but that of the Legislature or the public. Either the Legislature should refuse to make laws on the subject at all, or it should watch with the most jealous care every word written in the statute book dealing with these matters. It is no argument to say that mistakes will be made. Of course, mistakes will be made; but that is a reason for caution, not for recklessness. When a switchman ditches a passenger train and kills a dozen people, we do not allow him to throw his responsibility over his shoulder with the remark, "Accidents will happen." We take that man and put him in jail as one guilty of carelessness amounting, in fact, to crime. Of course, we cannot arraign a whole Legislature in the same way. But the very fact that others must bear all the results of their bad acts, the fact that they themselves cannot have even the satisfaction, such as it is, of expiating their offence, should make the representatives of the people still more anxiously careful in what they do. Yet, while this is true, it is also true that the best bulwark of legislative soundness is not the goodness of the legislators, but the purity and strength of public opinion. If that opinion crystallises in the form of good laws, so much the better. But it can do its work well enough if left fluid and formless, but ready to take form against any man who proposes or endorses a scheme which involves gambling or the consequences of gambling.

In short, the experience of Massachusetts in the closing decade of the nineteenth century shows that the dangers of insurance are not merely things of the past, but facts of the present 


\section{Company Frauds}

or the future. We may plume ourselves upon our superior knowledge and our infallible good sense enabling us to detect and prevent such swindles as that exposed in this chapter. There is no man so easily deceived as he who assumes to be sharper than others. In its own opinion, and in the opinion of many competent and independent judges, the Commonwealth of Massachusetts, in I888, was one of the most intelligent communities on the face of the earth. Yet thousands upon thousands of its people, including a majority of its legislators, were hanky-pankied by a trick which, in its essence, is as old as the origin of swindling, and which, in its form, was the very embodiment of childish absurdity, a scheme so utterly bad that, though permitted, if not endorsed by the Legislature, and never put under the ban of any statute law, it ran its course and died, rotted, and disappeared in less than four years. This is not a reason why others should look down upon Massachusetts. It is a reason why they should ponder the weakness of our common humanity and guard their own pockets.

Before closing this chapter, it would seem well, so much having already been said about it, to mention the fate of the Order of the Iron Hall. The concern lived a greater number of months than the vast majority of its imitators. But it too accumulated more liabilities than assets, and went down in I892, a receiver taking over its affairs in that year. In ordering the appointment of a receiver, the judge referred to charges of misappropriation of funds that had been made and said: "Such management is something the like of which this court has never heard. . . . It looks as though the order was kept up for the benefit of the supreme officers, instead of for the members of the order." The grand jury, in October, 1892 , found an indictment against certain officers of the order for embezzling $\$ 200,000$, and the man against whom these charges were mainly directed fled. About $\$ \mathrm{I}, 250,000$ was returned to the contributors. 


\section{CHAPTER XIX}

\section{CONCLUSION-APPLICATION}

Summary of what has Been Shown-What the Facts Mean-Dangers in the Future as well as in the Past-"What are you Going to Do about it"-Benefits and Dangers of Statute Laws-Benefits, without Danger of Enlightened Public Opinion-What are you Going to Do about it?

$\mathrm{W}^{\mathrm{r}}$

ITH the facts given, I rest my case.

In the opening chapters, I expressed the opinion that, in the nature of things, the insurance contract is more likely to be abused than any other contract known to commerce. I have sought to make that good by showing that in those countries where it is best known and most widely practised, insurance has led to whole cycles and systems of crime and evil. I have shown how, in all its great branches, it is prone to evil. I have shown, not only that it offers bribes for the commission of sins against the law, but that, in thousands upon thousands of cases, those bribes have been taken and the crimes paid for have been duly committed. And I have shown, not merely that there are individual and sporadic cases, but that, in time, these evils become systematised, and there are those who make them a means of livelihood. Though, to the mind of the man whose attention is occupied with his own affairs, there may appear to be no relation between the building of unseaworthy ships, the mismanagement of a friendly society, the burning of a town, and the starving of a baby, I have shown that all these and countless other crimes and social evils are due to one central cause-they are the fruit of diverse graftings upon one stem. 
Does that mean that the tree of insurance which bears such fruit should be cut down? By no means. In the first place, that would be unjust; in the second place, it would be impossible; and, in the third place, it would be unwise. It would be unjust because it would expose men to risks for the avoidance of which they are ready and able to pay; it would be impossible because insurance is built in as part of our economic and social fabric; and it would be unwise because insurance bears good fruit as well as bad, and the good can be increased while the bad can be done away with.

Here I venture to repeat one more of the things I have repeated before-that this work is not inspired by any desire to hold insurance up to contempt or execration. As Tennyson tells us:

\section{$\mathrm{He}$ is the true Conservative}

Who lops the moulder'd branch away.

Insurance is a living and growing thing; and, like other things of life and growth, it must either become better or become worse as time goes on. It has not in itself, any more than other things have, complete powers of self-regeneration. Unless it is watched, and evil tendencies in it checked, it will grow toward evil, at least in part, and there is always danger that the evil tendency may overcome the good. If we are to keep the tree healthy and its fruit sound, we must lop away the mouldered branches, as disease or decay shows itself.

For, the wrongs of which I have spoken have not been wholly in the past. Some of them are with us to-day. Some of them have been so imperfectly suppressed that there is danger that they may break out again. An institution which, in every age since its adoption and in every country in which it has been used, has developed dangers to the body social will continue to exert an evil influence in the future, unless preventive measures are taken. Nobody can say in what form future evils will appear. As has already been stated, I fear, judging from 
such study as I have been able to give the question, that our danger is in an outbreak of homicide for insurance money. But there are so many factors in such a calculation that in attempting to forecast the future, one is almost sure to be mistaken. The advantage of attempting a prognostication is that it may assist in the main object, which is to arouse the public to a belief that there is trouble ahead, unless we determine to prevent it.

Judging from what $I$ have heard in conversation and read in such literature on this question as I have been able to master, I fear that among my readers are many who will say: Well, that is the insurance companies' business; if they care to pay bad losses, we can stand it as long as they can. As such an idea is a complete block to any discussion of the case, I trust that those who understand the matter well enough to be unaffected by it will bear with me while I try to win to my aid those who are mistakenly inclined to regard this as a matter of interest to insurance companies alone. We have met the same point before, but it was in dealing with some special branch of the business. Let us now consider its general effect.

I would ask the candid reader to go mentally over the facts I have given in previous chapters, and say from which epidemic of crime and wrong-doing the insurance companies have suffered. Surely it must be clear that not one of these has injured them, but that, in the broad sense and on the average, they have profited by them all. I do not mean to say that an insurance company would hire a man to burn down a building on which it had issued a policy, merely for the purpose of booming business, or that it would deliberately foster any other crime for a similar purpose. But I do mean to say that the greater the average risk of loss, - up to a point, and that point so high as to be hardly worth considering as a practical matter,-the more certain people are to insure those things in which they are interested, and the more readily will they pay 
high and profitable rates to the insurance companies. It is quite true that, if there are among the insured those who suffer from wilful and criminal losses, as well as those who suffer only from accidental and, humanly speaking, unpreventable ones, the latter class will, after a time, decline to be included with the others in the striking of average rates, and will insist upon being put in a class by themselves. When that is done, and not till then, will the losses to the insurance companies be so heavy as to make it impossible for them to pay them out of the premiums received. But, in practice, it is long before that condition is reached. In marine insurance, as we have seen, many of the most careful and reputable firms went on insuring their vessels with the same underwriters as were patronised by the ship-knackers whom Plimsoll exposed, and, risk for risk, at about the same rates. Suicide is not a bar to the payment of life insurance, in many cases, and the average man does not know whether he pays the same rate as one who plans suicide, or a lower or higher rate. In fire insurance, though the moral hazard is supposed in practice to be considered more than in any other branch of the business, as a matter of fact, as everybody knows, a man who can be insured at all can be insured at as low a rate as his neighbour, regardless of the record of the two-and this notwithstanding the fact that it is clear beyond all controversy and must be known to every man that the insurance money paid on account of incendiary fires is taken from good people and paid to bad people, not as an accident or for charity, or for reformatory purposes, but to reward the bad people for their crimes. An insurance company does not seek to make money out of any one risk-it works wholly upon average. If, on the average, the operation turns out well, the shareholders are perfectly satisfied; and, with shareholders satisfied, did any one ever know directors or managers to complain? If the average does not prove remunerative, the obvious remedy, and the one which the insurance company first 
seeks to apply, is, not to exclude the criminals, but to raise the rates all round. If this can be done, as it often has been done, a profit is realised, and the trouble and danger of selecting risks is avoided. Thus, the insurance companies have no interest in preventing crimes for which they have to pay, if they can collect from their policy-holders enough to meet this drain upon their income and still leave a profit over all. But, while having no interest in preventing crime, they have an interest in increasing the risk, whether from crime or any other source. The greater the risk of loss and the higher the premium they can charge without excluding thereby too many possible customers, the higher their rates of expense and profit may be without exciting remark. The reason for this is nothing peculiar to insurance,-it is a universal principle. When a man's income is great, whatever the reason, that is counted economy which would be considered wild extravagance in another. Even should his income be merely prospective, contingent, or fictitious, we do not expect the man to whom it is attributed to live as closely as one whose income is known to be small. Moreover, if we find a man of large income adding thousands to his permanent investments, we think less of it than when a poor man buys a second-hand piano. Apply that principle to insurance companies. Shareholders love large dividends, and are not likely to inquire too curiously into the management that wins them. The manager likes a large expense account because it surrounds him with conveniences and luxuries at no expense to himself, besides enabling him, on equally economical terms, to gain kudos with those under him. Therefore, if increased risk of loss, whether due to crime or any other cause, can be made the excuse for an increase of rates, the result would be beneficial to both shareholder and manager. That being the case, why should either shareholder or manager, as such, seek to put down crime? Looking at it as a matter of business alone, the criminal is, to them, a benefactor. 
This pushes us back one step. If it is not to the interest of insurance companies to prevent these criminal losses, surely it is to the interest of those who pay insurance premiums to prevent them. At first glance, this seems perfectly obvious. But, as we look at it more closely, we see that it is not really so true as it appears. It is quite the common thing for the merchant, in making up the cost of his goods, in order to find on what he must base his percentage of profit, to add at the last an item, "taxes and insurance." This shows that, in the rough, insurance is regarded in much the same light as a tax would be. Of course, it is not so in form, but in fact there is more truth in that way of looking at it than would at first appear, and particularly in discussing the point we now have under consideration. If a merchant is taxed like others in his line, and if those taxes are not so high as to cut into his percentage of profit, it matters nothing to him what they are; for he simply adds them to the price of the goods, and gets from the public what he pays over to the tax-gatherer. The higher the tax under those circumstances, the better for the man of substance, because every item of expense added to the business adds to the capital necessary to "swing it," and reduces the number who can hope to compete in it. Carry that far enough and you have a monopoly. In this way, if insurance rates are the same, risk for risk, to all the trade, the business man merely includes the amount among his expenses, adds to that item, as to others, his ratio of profit, and charges all up against the public. Of course, when a man is himself the consumer of the goods insured, or, for any other reason, is precluded from passing the insurance item on to the public, the case is wholly different. But insurance is, in very large degree indeed, a matter of commerce; it is a thing bought by middlemen who collect the cost of it from the public in the prices of goods. The cost of ships, trains, and other means of transport must all appear in the price of the goods they carry; so must the cost 
of insurance that covers the goods, from the moment they appear as what some economists call " raw material," until they are passed over the counter of the last dealer into the hands of the consumer. At that point, with respect to a large class of goods, insurance practically ceases; for that which may have taken a year or more to make, transport, and keep on hand for sale is consumed in a few days. The producer or dealer is not interested in having the cost of goods low. If the cost is low enough to enable him to compete, the object is attained. And this applies to that part of cost represented by insurance as well as to any other part.

Thus we see that the questions of the insurance rate and the cause of it are not questions for the insurance company, or for the middleman or business man. We are thus driven back another and final step. We find that it is a matter in which the public are interested and with which the public should deal.

This we see when we regard the matter as merely one of business - an affair of dollars and cents. But, even if this reasoning were wholly wrong, the case in favour of public interest and public action in these matters would be practically as strong as ever. Higher prices for insurance are a mere market question. If we must pay those higher prices, the loss, so regarded, is only a money loss, and we of the great public can afford to add it to the others we must suffer and dismiss it with a laugh. Crime, however, breeds crime, and, in the end, brings utter social demoralisation. The duty of preventing crime, or of so ordering our institutions that crime shall diminish rather than increase, is not a duty laid upon insurance companies or upon those who deal with them, but upon men and women as citizens and members of the body social. To leave such a function to others, no matter who they may be, or no matter what the excuse, is to invite the fate of those who neglect their own privileges or shirk their own duties. To the every-day man, therefore, the man to whom this book is ad- 
dressed, belongs the function of lifting insurance from its present to its true level, and of making it a power for good only and not for evil.

The question will naturally be put by those who have done me the honour to follow me thus far: What is the remedy ?-in the words of the immortal Tweed of Tammany and the Tombs, "What are you going to do about it?" The question is so perfect a stop to mere argument that it deserves a better origin. Certainly, in this case, it calls for a fair answer. In the minds of a great many, the question fairly translated would read: How would you change the statute law so as to meet the case you assume to have made out ? Let me, then, come down to details, and answer as well as I can those who put the question in this form.

My plain answer to the question as to what change should be made in the law is: I do not know. The evil, as has been seen, is widely pervasive, and it varies in its manifestation according to the kind of insurance under consideration, the character and habits of thought of the people, and the law of the country. The faith that most people seem to have in the power of mere statute law to overcome any evil whatever is most touching. I confess that I do not share it. A good law, properly enforced, will certainly result in curing any evil aimed at. But you cannot order the Legislature to make a good law and the Executive to enforce it as easily as you can order a manufacturer to set up a windmill at your farm or country house, with a man to start it going and instruct your assistants how to run it. The problem has its complications, and these complications must be studied and allowed for before we can fit a law to the circumstances. Besides, a bad law does not remain merely a dead letter, but is apt to be used as a screen behind which those who prey upon society may arrange their plans, and which they may use as a sure defence if their conduct is called in question. Thus we see that the bond-investment 
mania and frauds arose from a change in the law which, on the face of it, seemed most innocent, if not laudable. In some cases, in fact, a change in the statute law is not needed to produce this effect. The circumstances of the country may so change as to give to existing law a new reading and make a new form of insurance possible under an old and tried law. Some discovery in finance may be applied so as to make, in effect, a new gambling device possible, based more or less upon insurance principles, and of such a nature as to be able to hide in some nook or cranny of the statute law. The ordinary law respecting the friendly societies of England was all right. But when social changes and new commercial systems made the "collector" a living fact, the law was found to menace the welfare of the people in many ways, making special changes to meet the special case peremptorily necessary. To cite an instance outside of the facts already given in this book, let me quote from the report of the Committee appointed in 1889 by the British House of Commons to consider a bill then before Parliament affecting friendly societies:

It appears to your Committee that this right of nomination, as it at present stands, is far too open and may easily be made use of to evade the provisions of the Act, and may possibly, from time to time, act as an incentive to fraud and still more serious crimes. It is one of the matters in which collecting societies have a great privilege conferred upon them not conferred upon the policy-holders of companies.

The quotation covers a point not directly dealt with in previous chapters. It was not instanced for the simple reason that there is no evidence to show that this lesion in the law has ever led to any serious outbreak of crime or wrongdoing. But what does this statement of the House of Commons Committee mean? It means this: In the old friendly societies, it was the practice for a member to nominate the person to whom the benefits he purchased by payment of dues were to accrue-wife, 


\section{Conclusion-Application}

child, dependent, relative, or friend. There was no practical danger in this, because the whole transaction had in it a minimum of commerce and calculation and a maximum of friendliness and mutual help. Besides, the members were themselves the guardians of their own funds, and any cause of general dissatisfaction would at once be known and would at once result in the collapse of the society. But with the substitution of the paid collector for the common interest and good-will, which, up to that time, had held the societies together, the position completely changed. The collecting society was, in form, a friendly society, and was governed under the laws made for the control of such associations; but it was, in fact, an insurance company, and, if laws were necessary to govern insurance companies, the same laws were necessary for the government of collecting friendly societies. With the power of nomination left in the hands of members of such societies, it was possible for a man to insure the life of another in whose life he had no sort of interest. In short, there was here exactly the same condition of affairs as that which, in Pennsylvania, gave rise to the graveyard insurance villainies which have already been briefly recounted. That the effect was the same in some measure, instances could easily be quoted to show. The fact that a Committee of the House of Commons thought it worth while to call attention to the matter is proof enough that it was one of practical importance. Just why it did not lead to a similar outbreak in England to that which occurred in Pennsylvánia, who can say? England had already had her debauch of this kind, before the statute of "insurable interest," so often referred to, and this may have had a warning effect. The greater activity of public opinion due to this fact and to the large number of real friendly societies may also have been' among repressive influences. Or, it may be that the general social conditions of the country were not favourable. A spark that, at one time or place, would set hundreds of miles of forest 
ablaze, at another would burn over an acre or two, and at another would fall dead and harmless. To the extent that the laws of England encouraged or facilitated the formation of collecting friendly societies, they caused the danger referred to while seeking to avoid other dangers. There is hardly a law governing insurance to be found on any statute book to-day that does not give rise to some insurance abuses while seeking to cloak or cure others.

But insurance is not self-contained. The fact that a law relating to insurance does not give rise to insurance abuses does not prove that law to be perfect. It may have an injurious effect upon commerce generally, or upon social life generally. The perception of this fact by the people of Britain was the great obstacle which stood in the way of Plimsoll and his friends when they proposed changes in the law to prevent the sending to sea of coffin-ships. The opinion expressed by many who were competent to speak on the subject was that the change proposed would result in British ships being generally transferred to the protection of foreign flags, to the crippling of British commerce, and so to the overthrow of Britain as the great maritime power of the world. Let it be granted that their opinions were the result of panic or self-interest rather than of sound reasoning, the fact remains that there was enough merit in those opinions to so arouse public feeling as to prevent for a long time any legislation, and to make legislation, when enacted, very conservative, not to say faltering, timid, and, in great measure, ineffective for the purpose in hand.

In seeking for other things, I came across an instance showing how wholly unexpected are the results of legislation. It is strictly in point, but would be of interest even wholly apart from its relation to the matter of insurance. The law of Great Britain was supposed to do the friendly societies a great favour in exempting them from the stamp tax payable by insurance 


\section{Conclusion-Application}

companies upon their policies. Naturally, this would be supposed to be a great hardship in the case of the "industrial" companies-"companies," it will be noted, not "societies," for these were joint-stock concerns and fierce competitors of the collecting friendly societies in their special field. But the Commission on Friendly Societies, appointed in 1870, in their final report in 1874 quote the statement of Mr. Harben, Secretary of the Prudential Insurance Company, then, as now, one of the greatest of the British "industrials," that, instead of desiring to be relieved of this tax, which cost them between $£ 3000$ and $£ 4000$, his company would object to its repeal. "It is a very curious thing," he said, "but the people imagine that if a policy has a government stamp it has some peculiar guarantee about it. We would not dispense with the stamp upon any consideration. . . . One of our great canvassing features is that we show a government stamped policy."

How could any mere legislators foresee that a law passed by them intended to favour the friendly societies, and, on the face of it, likely to do grave injury to their chief rivals, the "industrial " insurance companies, would be so deflected, by popular ignorance and the craft of canvassers, as to have the very opposite effect? Though this is the most curious instance of laws relating to insurance turning out quite differently in operation from the forecasts of those who designed them, the result itself is by no means exceptional. In fact, insurance is so complex a question that it is the rule rather than the exception for laws relating to it to develop a back-action movement very disconcerting to legislative engineers, and, often, most injurious to the public.

Notwithstanding all this element of uncertainty, however, there are some broad principles, by recognising which we may legislate on this subject with reasonable safety. I venture the opinion that all merely repressive laws are unjust, and, in the long run, injurious. Regulative laws are objectionable in 
the same way, and only in less degree. That, I know, condemns all checks upon the formation of companies, all statutory conditions as to policies, all legal standards as to financial stability, and so on. In fact, it would lead to the same free trade in insurance that we now have in the growing and selling of potatoes. I know that; but my opinion remains. If one man chose to go into the business of insurance, and another preferred to buy the protection thus offered, each would be free, under the conditions I suggest, to enter into the contract; and, if any dissatisfaction arose, the dissatisfied one would have the same remedy as if the transaction were one in potatoes-neither more nor less. If a man preferred to form a joint-stock company to give insurance or to grow potatoes, the concern and those dealing with it would be governed by the law governing business transactions, modified as might be necessary to apply to bodies corporate and politic instead of to individual citizens. And the plainer, simpler, and more coldly and radically just that law, the better for all. As Henry George puts it, it is no part of the business of the State to protect a man against the consequences of his own folly. If a man buys a horse, "unsight unseen," and it turns out to be such a charger as Petruchio rode to his wedding, or if he buys security from an insurance company, which company is a mere wildcat, the business is purely his own; and in justice, and according to true policy, the State has nothing tc do with the matter, either in the way of checking such bargains, or in bringing together again the fool and his money.

It is no part of my purpose, however, to argue in favour of an ideal state of law. That would be the proper subject of a separate work backed by an active propaganda. I merely state the ideal here as a true answer to this question, "What are you going to do about it?" as referring to statutory enactments on the subject. Not more than one man in a thousand would be convinced of the righteousness of free trade in insur- 
ance; and, of those intellectually convinced, not more than one in ten thousand would have the moral courage, even if the power were given them, to establish such free trade and to repel all efforts of fools and experimenters who sought to "regulate" it in one way or another. The men who understand a principle, believe in it, and act upon it, are nearly all dead. Those living are scattered here and there, and are known, as were the others when alive, as cranks and dreamers. It is quite true that those cranks and dreamers, if they chose, could turn the world rightside up on this, as their predecessors have done on other questions. But that would be a big job, and a job that I, for one, am quite ready to leave unattempted.

However, we see, as a practical matter, that laws have been passed which seem to have had beneficial effects. Cannot these be strengthened or extended so as to cover the field sufficiently well for practical purposes? The suggestion is like asking a navigator to cross the ocean while leaving his knowledge of astronomy at home. But those who love to call themselves "practical" men prefer this kind of navigation in sociological waters. If we are not to be guided, as, I admit, we cannot be in a "practical" world, by the sure calculation of principle, let us do what we can with such methods as are allowed, with principle as a sort of check and guide wherever it can be made available.

The one great law, in my opinion, that makes insurance in this age possible is the British statute of 1774 , so often spoken of in this book and in all English literature on the subject, cancelling contracts made in the form of insurance when the party has not an "insurable interest" in the thing insured. This provision, in one way or another, has become embedded in the law of English-speaking countries, and it looks as if it were there to stay. It stopped, as if by magic, those gambling assurances against which it was directed, and it is the one bulwark, I believe, that protects us against their repetition. In 
the gambling manias and criminal outbreaks discussed in previous chapters, as well as those which, owing to lack of space, could not be dealt with, it will be seen that the central difficulty, in almost every case, is the neglect or violation of the great principle laid down by that law. The success of that law, I venture to say, is due to two facts. The first is that it makes insurance conform to its own nature, and prevents its being used as a cloak for other purposes; and the second is that it confines the statute law fairly well to its true function-that of attending to matters of public concern.

As stated at the very outset of this work, insurance is designed only to distribute loss. The statute referred to provides that only those liable to loss shall be allowed to contribute to the insurance fund. If any other seeks to do so, he simply leaves so much money in the hands of another person. It is not, in law, added to the insurance fund, and, under the law, it cannot be recovered. The fact that this law is not well understood by many eminent lawyers, the fact that exceptions to it are statutorily permitted even in the country where it had its origin, the fact that it has not been always enforced, - these things do not affect the question. The law is there, and, to the extent that it has been enforced, its effects, so far as I can judge, have been good, and good only. I believe, also, that, if that law could be applied and enforced in every case, it would meet practically the whole difficulty. But the enforcement of that statute law by the methods relied upon for the enforcement of statute laws in general is clearly impossible. For instance, if a man who, unknown to any living soul but himself, -and such is usually the case, - is resolved upon suicide, insures his life for five thousand dollars in favour of his wife, the spirit of the law is violated. For, the woman can have no interest in that life. In fact, logically considered, there is no life. The position, in effect, is the same as though the man had already died, but had been galvanised into such a semblance of life as to 
deceive the insurance company, and so secure a policy by false representation. There is no "risk" of loss, but a certainty of loss. Such a man is in a class by himself. If the main fact in the case-the determination to commit suicide-were known, the insurance man, if he accepted the application at all, would do so only on condition that the insured should pay something over one hundred per cent. premium. As a citizen, he would hand the intending law-breaker over to the police. Or, suppose that a wife intends to get rid of her husband, and insures his life before killing him, so that she may have money as well as freedom. There is a clear violation of the principle of "insurable interest," for the woman would suffer no loss by the death of her husband, and is not, therefore, in the same class with those women to whom the life of the husband has an actual money value. But, in either of these cases, how can it possibly be known that the element of insurable interest is absent? No system of courts, police, and punitive institutions could ever meet such cases, nor could any possible variation or extension of the law enable those charged with its enforcement to ascertain the facts.

What then?

In the first place, I venture to say, the proper course is to make this good law cover as many cases as it will. Do away with all exceptions and limitations, and provide that, for every form of insurance, and in every case, insurable interest shall be the very corner-stone of the contract. This element of insurable interest absent, let the contract be absolutely void, and any money paid as premium non-recoverable. It may be said that this would lead to repudiation of their liabilities by insurance companies, and would introduce an element of uncertainty which would be most undesirable, especially in the case of life insurance. This difficulty is more apparent than real. One of the evils of insurance with which I would have dealt more extensively, had there been space, is the tendency 
on the part of managers to pay losses too readily and with too slight investigation. Among reputable companies, it is the rule to pay when anything like reasonable proof of loss is furnished. There is practically no danger that the law, no matter how stringent it may be, will be taken advantage of by companies that have a character for solvency and fair dealing to maintain;-and people who deal with others in such a contract as insurance should surely be left to the consequences of their own acts.

In the second place, in cases that are not covered by the law of insurable interest-that is, cases in which the law cannot be practically applied by the ordinary machinery-I would have the principle of that law applied by force of public sentiment without the intervention of a statute. I have shown that the people are vitally interested in this as a practical matter. The man whose house may be burned down to-morrow through the action of a firebug who works for insurance money; the man whose life, or the life of whose friends may be endangered on an ocean trip by some crazy insurance contract of which he knows nothing, but which is more dangerous than a hole in the ship's hull would be; the man who, as a member of the community, finds himself both injured and disgraced by horrid murders for the realisation of what are, in effect, gambling insurances, - surely such a man is"interested in the elimination of these dangers; surely it is worth his while to let it be known that he will take his own part against those by whom he is menaced.

Those who fly to the Legislature for the righting of every wrong, and the conformation of the conduct of others to their particular way of thinking, overlook what is, in my opinion, a far greater law-making power. For one statute that is passed in the Legislature, a dozen are passed in the great referendum of public opinion. Because of the laws passed, but never formulated, men and women ally themselves with certain 


\section{Conclusion-Application}

political parties, churches, and social clubs; they wear certain costumes, keep certain hours, sing certain songs, and observe ten thousand conventions which they had no part in making, and which, to them, are merely arbitrary. It is because of this very public opinion that insurance companies, as just hinted, are willing to pay losses which, in justice, they should not pay. A company that wishes to do business with men as they are today must not stand too strongly upon its own rights or those of the body of its policy-holders when a claim is presented to it. It may cost some thousands to pay the claim; but it might cost loss of prestige worth hundreds of thousands to contest it. Except for the consideration, "What would people say?" it would be wise, as it certainly would be right, for the company to contest the claim. But, when that feature of the case presents itself, it seems to be wise-in the way of worldly wisdom, anyhow-whether right or not, to "pay up and look pleasant," to use a phrase much in use among insurance men. Why should not this same force of public opinion operate to put down those crimes to which insurance has given rise, by stopping them at their source? When we find a monster like Wainewright, made what he was by the morbid longings for the bribe of insurance money, why should not public reprobation drive into repentance-and the bringing forth of the fruits meet therefor-or retirement those who held out that bribe?

It may be answered that this would not be fair; that an insurance manager cannot know the exact circumstances of every policy-holder or the personal character of every beneficiary of a policy. My answer is that, if the manager does not know these things, he is not fit for his place and should make way for another man. The president of a railroad does not examine, and cannot examine, every sleeper, fish-plate, and bolt on thousands of miles of road. But if he is fit for his place, he knowes that every detail in this respect, bar accidents, such as the death by sudden and unlooked-for stroke of one of his men, 
a wash-out due to unforeseeable weather conditions, and so onis perfect. How? By having men under him who have men under them who will attend faithfully to these matters. The good old story of the expert who opened the safe the key of which was lost, and charged one dollar for opening the safe and ninety-nine dollars for knowing how, is still true. The railroad president is paid, not for manual or clerical work-men for these services can be hired for day's wages anywhere or at any time-but for his ability to choose men and direct them. The railroad president who consolidates lines, builds up a big business and makes dividends, wins applause for his success. But if, in order to do this, he found it necessary to starve, poison, or maim passengers, and to destroy goods entrusted to him, he would be allowed no opportunity for the exercise of his talents. Public sentiment would put a stop to such a career before it had more than started. Why, then, should we allow such a plea on behalf of an insurance manager, or of all insurance managers together, as that arson, barratry, murder, and every crime in the calendar are the inevitable accompaniment of the insurance business, and that they, the insurance managers, must not be called to account, no matter how their operations may bedevil the people?

The only possible argument in favour of such a plea will be found to rest ultimately upon the assumption that these things are inevitable-that is to say, the thing is so because it must be so. This style of argument is out of place in this age. Within the memory of men now living, we have learned that fever is not an unavoidable dispensation of an inscrutable Providence, but the consequence of violated law. We are now beginning to realise that the millions of people sacrificed to " the white plague of the north," consumption, are not chosen by inevitable fate. Even if those touched by the finger of this destroyer cannot be dragged from under his ban, the plague itself can be circumscribed so that he may not reach those who 
now are free. As we are beginning to look upon consumption with the same eyes as those with which we regard the plague, so we must learn to consider insurance-in this respect at least -exactly as we do railroads. Let a succession of wrecks, whatever the cause, take place on any railroad, and that concern will hasten, by explanation, by change of system, even by change of management, if necessary, to break the effect of public displeasure and win back its lost trade. It is a common saying among railroad men that every man in the country thinks he can manage the road better than those do who have it in charge. But nobody thinks that way about insurance companies. Insurance is supposed to be a recondite subject, a thing of mystery, a business which one must be brought up to if he is to understand it.

As a matter of fact, if there is a distinction to be made between the two, it should teach us consideration and charity for the railroad management. Insurance has its technique, of course; but those who seek to make us believe that the whole business, therefore, is beyond the comprehension of the ordinary man are like the ancient Egyptian priests who set between themselves and the people a screen of mystery and superstition in order to cloak their own self-seeking. It is safe to suspect such men; and it is necessary to our own safety and well-being to set them aside. An honest insurance company can conduct its business in the open light of day, and the more the public know about the general principles upon which it is managed, the more successful it will be. A well-managed insurance company, one that does a big business and earns good dividends, is not necessarily an accessory before the fact to crime or gambling of any kind. Let the people understand that insurance in the past has played the part of such accessory and has, to some extent at least, made profit in this disreputable and outrageous fashion; let the people understand that, even to-day, it carries a perceptible percentage of crime and wrong; 
let the people understand that what it has done in the past and what it is doing to-day it will do in the future, by new methods and to an increased extent, if opportunity is offered,-let these things be understood, and the first great step toward reform is taken. Then, let it be understood that these things are unnecessary to-day and will be unnecessary in the future, as they have been in the past; let it be understood that evils of this kind that cannot be reached by statute can be reached at once by educated and vigilant public opinion,-let these things also be understood, and, so far as honest, self-respecting communities are concerned, the future is assured.

There is one specific point upon which, if I had the power, I would at once focus public attention. My own views upon it are very strong; but if they are to be urged it should be in a separate work, for there is no time here to consider the arguments pro and con, and a one-sided statement would be unfair to the reader. As the subject has come up in the foregoing chapters, I have touched upon it, but, I trust, without undue weight. I refer to the practice, which may be said to be universal in insurance, of employing canvassers to bring in business, and paying those canvassers by a commission on the premiums they bring in. There are exceptions to this rule, I know, and those exceptions -are probably growing. But, whether commonly used or not, the commission system appears bad in principle, and appears to work out badly in practice. Not to argue the case, but to convince the reader of the importance of the point, let me show the nature of this commission system.

If a man had ten thousand dollars of his own to lend, he might well pay a consideration to the man or men who would place it advantageously for him, remunerating each according to the amount he placed. The lender would, himself, check every detail, and would not place a dollar except where it would be safe according to his judgment. But if he were 


\section{Conclusion-Application}

asked to take ten thousand dollars of stock in a concern that would loan millions, or, perhaps, hundreds of millions, through men who would be remunerated directly according to the interest-money they brought in, and indirectly according to the amount they placed, would he not at once refuse to venture his money so? The agent of such a company would have a direct interest in ignoring, or even hiding, weak points in the financial character of those to whom those loans were made, and nothing but a most elaborate and costly system of checks and counter-checks would enable the company to overcome the bad influence caused by their own system. The system pursued by banks is, manifestly, the wise one-to pay to officers salaries according to their proved ability in making profits. If a commission is paid, why not pay it upon the results of the business, rather than upon the mere incident of the gross income? If there is anything in the constitution of an insurance company to make the principle here laid down work differently from the way it would work in any other business, or to make it inapplicable to insurance, I am not aware of it. The burden of proof, it seems to me, is on the insurance men who follow this practice. When a Royal Commission in Britain thinks it worth while to deal with the commission system in connection with child life insurance; when we find, as we do, even insurance men themselves condemning the payment of commission to fire-insurance canvassers; when it must be obvious to every man that the agent paid by commission has a constant interest in favour of getting much business as against getting good business, - surely that system is, at least, upon its trial. And when it seems plain, according to reason and according to experience, that this system promotes the evils in society to which insurance, even when most carefully conducted, is too apt to give rise, the public should not be satisfied until some justification of it is forthcoming or it is frankly and completely abandoned. 
Insurance being a business liable to such abuses as have been set forth in the brief and imperfect summary here given, surely it is in the public interest that all engaged in that business should be united to resist that evil tendency. At the very least, we should not have a class, and that the largest, of those so engaged, whose interest it is to extend the business regardless of this consideration, which is so important to the public.

It will be seen that I look for a minimum of good from legislation, and a maximum of good from the direct action of public opinion. My answer to the question, "What are you going to do about it?" is, therefore, a plea that this is no affair of mine but of the public's. It is the affair of "the man in the street," to whom this book is addressed. In short, the question is, really, not, What are others going to do about it? but, What are you, reader, going to do about it? I venture the opinion that, if you will make up your mind to encourage those who carry on insurance properly in your interest, and to discourage-and repress, if necessary-those who carry on this business regardless of your rights and welfare as a citizen, insurance will be improved to-morrow.

Nor would I make the appeal on merely selfish grounds alone. The effect of the insurance policy you carry is not confined within the four corners of that contract. That paper is but one of thousands issued by the same company; were it otherwise, its business could not continue. That company is but one of hundreds, all operating upon the same great plan; were it otherwise, the business would go to pieces. Insurance is, thus, a great factor in our every-day life, and I have shown that it may be a factor for evil in many obscure and unconsidered ways;-evil, not to you alone, who have paid the company money and hold its bond, but evil to thousands and millions who, it may be, know neither of your existence nor of that of the company. You have no right, while benefiting yourself by this private contract, to encourage, or even appear 


\section{Conclusion-Application}

to encourage, features in the business which will work out in injury to others. It is not necessary that you should inquire curiously into the principles of insurance, or even into the minutiæ of any company's affairs. But if you find an insurance company whose business has led to murder, arson, or any other crime, throw your influence in favour of a company that has no such record. With ten men of property and influence, in every city where insurance is a large interest, ready to take this course, the business of insurance will be improved at once; and, with a hundred, it will be purified and exalted, and made the true protector of commerce, the righteous benefactor of the distressed. This done, things will be seen in their true relation; and, if statute laws are then required, they can be made-real laws, the wise expression of an enlightened public sentiment. 



\section{APPENDIX}

$\mathrm{T}^{\mathrm{H}}$ $\mathrm{HE}$ following is an extract from the report of the British Royal Commission on Friendly Societies referred to at page 285 , consisting of tables showing relative mortality of children, compiled from reports of the Registrar General, with comments by the Commission:

Average annual rate of mortality from all causes at certain ages to roo persons living in England, and in certain districts of

England, during the decennial period $\mathrm{I} 86 \mathrm{I}-7 \mathrm{O}$.

\begin{tabular}{|c|c|c|c|c|c|c|}
\hline & $\begin{array}{c}\text { At all } \\
\text { Ages }\end{array}$ & $\begin{array}{l}\text { Under } \\
\text { I Year }\end{array}$ & $\begin{array}{l}\text { From } \\
1 \text { to } 2\end{array}$ & $\begin{array}{l}\text { From } \\
2 \text { to } 3\end{array}$ & $\begin{array}{l}\text { From } \\
3 \text { to } 4\end{array}$ & $\begin{array}{l}\text { From } \\
4 \text { to } 5\end{array}$ \\
\hline ENGLAND. & 2.242 & I8.026 & 6.915 & 3.439 & 2.265 & I. 639 \\
\hline LIVERPOOL, . . . & 3.862 & 30.543 & I $8.49 \mathrm{I}$ & 8.256 & $5 \cdot 307$ & $3 \cdot 705$ \\
\hline MANCHESTER . . . . . . . . & 3.280 & 25.077 & $13 \cdot 58 \mathrm{I}$ & 6.294 & 4.077 & 3.09 .3 \\
\hline LEEDS $\ldots \ldots \ldots \ldots \ldots \ldots \ldots$ & $2.98 \mathrm{I}$ & 25.647 & 12.220 & 5.137 & 3.169 & 2. 104 \\
\hline FIELD..... & 2.907 & 23.746 & 10.702 & $5 \cdot 429$ & 3.607 & 2.417 \\
\hline PRESTON. & 2.785 & 26. IOI & IO. II 8 & $4.63 \mathrm{I}$ & 2.968 & 2.058 \\
\hline SALFORD . . . . . & 2.689 & 21.128 & I I . 395 & $4 \cdot 966$ & $3 \cdot 303$ & 2.303 \\
\hline BIRMINGHAM $\ldots \ldots \ldots \ldots \ldots \ldots$ & 2.663 & 21.529 & II.330 & $5 \cdot 326$ & 3487 & 2.336 \\
\hline BLACKBURN............. & 2.576 & 23.682 & $9.84 \mathrm{I}$ & $4 \cdot 446$ & 2.686 & 2.029 \\
\hline MACCLESFIELD $\ldots \ldots \ldots \ldots \ldots$ & $2.33 \mathrm{I}$ & I8.745 & 6.310 & $3 \cdot 25 \mathrm{I}$ & 2.155 & I.435 \\
\hline CHORLEY........ & 2.255 & I9 098 & $6.82 \mathrm{I}$ & 3 or6 & I. 892 & I. $43 \mathrm{I}$ \\
\hline DONCASTER.................. & 2.245 & 19.271 & 6. I 44 & 3.046 & I. 8 I 7 & $I \cdot 506$ \\
\hline
\end{tabular}

Comparative table showing the mortality from all causes in certain districts of England, to every Ioo persons deceased throughout England at all ages and at specified ages, during the decennial period I86I-70.

\begin{tabular}{|c|c|c|c|c|c|c|}
\hline & $\begin{array}{l}\text { At all } \\
\text { Ages }\end{array}$ & $\begin{array}{l}\text { Under } \\
\text { I Year }\end{array}$ & $\begin{array}{l}\text { From } \\
I \text { to } 2\end{array}$ & $\begin{array}{l}\text { From } \\
2 \text { to } 3\end{array}$ & $\begin{array}{l}\text { From } \\
3 \text { to } 4\end{array}$ & $\begin{array}{l}\text { From } \\
4 \text { to } 5\end{array}$ \\
\hline ENGLAND... & IOO & 100 & IOO & 100 & IOO & IOO \\
\hline LIVERPOOL... & 172.26 & 169.44 & $267 \cdot 40$ & 240.07 & $234 \cdot 30$ & 226.05 \\
\hline MANCHESTER. & 146.30 & I 39.12 & 19640 & 183.02 & 180.00 & $188.7 I$ \\
\hline LEEDS........ & I32.96 & $\mathrm{I} 42.28$ & 176.72 & $149 \cdot 37$ & 139.91 & I $28 \cdot 37$ \\
\hline SHEFFIELD ........ & 129.66 & 131.73 & $154 \cdot 77$ & 157.87 & I 5925 & I 4747 \\
\hline PRESTON . . . . . . . & 12422 & 144.80 & 146.32 & 134.66 & & $125 \cdot 56$ \\
\hline SALFORD .... & I I9.94 & II & 164.78 & 144.40 & 83 & $140.5^{1}$ \\
\hline BIRMINC & 118.78 & I I9 43 & 16385 & I54.87 & 153.95 & I 42.53 \\
\hline BLACKBURN. . & 114.90 & $131 \cdot 38$ & 14231 & I 29.28 & 118.59 & $123 \cdot 79$ \\
\hline MACCLESFIELI & 103.97 & IO3 99 & 91.25 & 94.53 & 95.14 & 8755 \\
\hline CHORLEY..... & I00 58 & 105.95 & 98.64 & 87.70 & $83 \cdot 53$ & $87 \cdot 3 \mathrm{~T}$ \\
\hline DONCASTER . & 100.13 & $106.9 \mathrm{I}$ & 88.85 & 88.57 & 80.22 & 91.88 \\
\hline
\end{tabular}


It will thus be seen that, whilst the excess of mortality for Liverpool, under one year is less than it is for all ages, it suddenly jumps in the second year of life, by nearly Ioo per cent. to considerably more than the average for all England at the same age, and only slowly diminishes from that time, so that whilst for the first year of life the mortality is I69.44 per cent. on the average for all England, the mean mortality for the four following years is $24 \mathrm{I} .96$. The same greater proportional increase of mortality in the second year of life is observable in Manchester, Leeds, Salford, Birmingham, Sheffield, Preston, and Blackburn, but in a diminishing ratio; whilst in Macclesfield, Chorley, and Doncaster it is less in the second year than in the first.

Now, according to a before-quoted statement of the sub-treasurer of the Liverpool "Royal Oak," children are frequently entered in general burial societies as soon as they are born, and by the rules of most, if not all such societies, they can only come into full benefit at the expiration of fifty-two weeks. Thus the great increase in the infant mortality of Liverpool takes place precisely within the year when infants can first come into full benefit in the general burial societies, and such mortality remains excessive for the next four years of feebleness, whether as compared with that for the whole of life or for its first twelvemonth. And we find that of the other towns in which the first phenomenon occurs, with or without the others, all but one have agencies of the same societies. On the other hand, the three towns in which the mortality is lower in the second than in the first year, and which all offer the phenomenon of a mortality slightly excessive in the first year, but below the average in the four following years, have all been specially noticed in the foregoing papers: Doncaster as the seat of a local non-collecting children's burial society, Macclesfield as that of an excellent amalgamation of local burial societies, Chorley as that of a local society of a singularly genuine type. 


\section{INDEX}

Accident insurance, 30

Adjuster of losses, his relation to the agent, I4I

Adventure, the, brig, 67-69

Agent, the, method of remunerating, see Commission system; his interest is with the insured, I4I142

A History of Our Own Times, quotation from, 102-IO3

Annuities, a confluent of life insurance system, 26; Tonti's system of, 190; abuses of, 196-198

Antiquity of insurance, 16-18, 188189

Applicability of the insurance idea to varying social conditions, 13

Architecture injuriously affected by fire-insurance abuses, 169

Arctic, the, wreck of, 90

Arson. See Incendiarism.

$A$ Salt Water Cure, W. Clark Russell, 47

Assessment endowment scheme, development of, $347-358$; leads to frauds, $358-368$; break of, 368 ; results of, 368,377

Assessment system, 323, 326-328, 348. See Mutual; Co-operative.

Atkinson, Edward, and the Mill Mutuals, I3I ; on the duty of owners to prevent fires, 133 ; on the fire loss, 149

Audley, "the Great," 28, 196

Baby-farmers and insurance, 284, 288

Barratry, opportunities for, 39; British laws against, 65. See Codling

Bills of mortality, 208

Bond investment scheme, how developed, 350. See Assessment Endowment.
Bottomry loans, 19 ; abuses of, 58 , 6I

Branches of insurance, their growth, 16

Burial clubs, their nature, 275,276

Carlyle, Thomas, Past and Present, quotation from, 265

Chamberlain, Rt. Hon. Joseph, 76, II6

Children, Cruelty to, Society for the Prevention of. See Prevention.

Chomage, 28

Claims. See Losses.

Classes in society, the best class are insured, 6

Classification of vessels, 95

Codling, William, "the noted Captain Codling," 67-69

"Coffin ships," 105

Collecting benefit societies, rise of, 276; position of collector for, 278; low class insured in, 279, 293

Commerce, relation of insurance to, I5, 33

Commissioners of Insurance, State. See State.

Commissions of investigation. See Royal Commissions.

Commission system of remunerating agents, in fire insurance, 136146; in child-life insurance, 278; generally, 398

Committee of British House of Lords, child-life, report of, 291

Committees of British House of Commons, reports of, fire, 160; child-life, 294; friendly societies, 386

Contingency necessarily part of insurance, 5

Contract of insurance, its nature, I, 4 
Co-operative insurance, I, 22, 30, 26I, 322, 326-328, 357. See Assessment; Mutual.

Cunninghams of Pennsylvania (Jerome Smith case), 329-330

Custodian of insurance fund tempted to fraud, 6

"Death-bed" insurance. See Graveyard.

Demoralisation due to insurance abuses, II, 46, 48, I55, 200, 333, 366. See Family.

D'Éon, Chevalier, his sex a subject of gambling, 199

Dickens, Charles, quotation from, 308, 3 I0

Distribution of loss the function of insurance, 3

Doctrine of chances, 205, 206

Employment and wages, need of insuring, 28

Endowments and insurance, 348

Family, the, and life insurance, 216. See Demoralisation.

Farrer, T. H., Secretary, Board of Trade of Great Britain, 88

Firebugs. See Incendiarism.

Fire briefs, $125-126$

Fire insurance, how developed, 2I, 122

Foul Play, Charles Reade, 43

Fraud incompatible with trade, 80

Frauds arising from insurance peculiarly bad, 6

Free trade in insurance, 389-39I

Froud, Capt. A. G., on marine losses, i 6

Future dangers from abuse of insurance, I2, 216-22I, 379-380

Gambling insurances, 52-53, 6I, $77,198,333$

Gambling, spirit of, in trade, 66 ; remarkable instances of, I99200

Graunt, John, contribution to vital statistics, 208

Graveyard insurance, its rise, 326332 ; methods of, 333-335; demoralisation caused by, 335, 343344; losses, 338-343

Gray, T., Assistant Secretary, Board of Trade of Great Britain, 89, I00
Great personages, why their lives are insured by others, 25, 26

Guilds and their work of distributing loss, 22, I24

"Handmaid of Commerce," insurance, 15

Hanseatic League and insurance, 58

Hedgepeth (Holmes case), 243, 256

Hole, founder of the "West Middlesex," 3I I-3I5

Holmes, H. H., his crimes, 24I257

Honesty in trade, tendency toward, 80

"Honour" policies, 78

Incendiarism, I53-I64

Individual liberty, insurance affected by, 63,180

Industry promotes and is promoted by insurance, I5, I7

Insurable interest, law of, I77, 201, 392-394. See Graveyard.

Insurance fund contingently owned, 5

Insurance Street in Mediæval Venice, 19

"'Insured," the, defined, 8

"Insurer," the, defined, 6

Interest and its relation to insurance, 20, 208

Iron Hall, Order of the, 353, 377

"Janus Weathercock," 223-227

Kipling, Rudyard, quotations from, 42, 49

Knowles, of the "West Middlesex," 3II, 316

Legislation, demand for, Ir8; dangers of, $170,372,377,389$; ineffective, worse than none, I72; difficulties of, in the United States, 320-323; peculiar operation of, 389

Life insurance, historical development of, 23,188

Limited liability applied to insurance companies in Great Britain, 318

“ Little goes," the, 20I-203

Lives of the great, insurance of, 25, I93 
Lloyd's, 21, 63. See Martin.

London, city of, and fire protection, 127-1 30

Loss, function of insurance is to distribute, 3

Losses, difficulties arising over payment of, 62, I4I ; not necessarily costly to insurance companies, $70,279,3^{80-385}$; by fire, amount of, 149 ; proportion of, due to insurance, I53; and farmers, I53154 ; carelessness as a cause of, I53, I69; apt to be too readily paid, 160, 393. See Prevention.

Lottery insurance, 203-204

McCarthy, Justin, $A$ History of Our Own Times, quotation from, IO2-IO3

Marine insurance, history of, 18,37

Martin Chuzzlewit, quotations from, 308-310

Martin, Frederick, History of Lloyd's, quotations from, 58, 59, 67,70

Master of a ship necessarily an autocrat, 40

Maybrick case, the, 22I-223

Merchant marine, British, statistics of, 75

Merchant of Venice, 18

Merchant shipping laws, British, amendments of, 65,74

Merrill, George S., Insurance Commissioner, Massachusetts, on endowment gambling mania, 347 , 354 ; quotations from report of, $363-367$; kindness to victims of mania, 366

Mill mutual fire-insurance companies, I3I

"Missing " vessels, 8r

Moral hazard and fire insurance, 133-136, 323

"Morocco men," 304

Mudgett, Herman W., alias H. H. Holmes. See Holmes.

Mutual insurance, general, I, 22 ; marine, 78; fire, I30. See Assessment; Co-operative.

Navigation, art of, injuriously affected by insurance abuses, 48

Navigation, its perils may be reduced, 95-97

Nomination of beneficiary, $3^{86}$

"Numerical " feature of endowment bonds, 350
O'Dowd, James, testimony as to overloading vessels, 90

"Open policy," 79

Over-insurance, its effects, 48,83 . I39

Owner of property, his position, 83 ; his duty to prevent fire, 133

Past and Present, Carlyle, quotation from, 265

Perils of navigation can be reduced, 95-97

Pitezel, Benjamin F. (victinı in the Holmes case), 24I-257

Plimsoll, Samuel, M. P., 99, 1 II

Poirier, Isidore, murdered for insurance money, 230

Premium, time fixed for payment of, 62

Prevention of Cruelty to Children, Society for, 290

Prevention of loss, not part of insurance, 3 ; not necessary to profitable insurance business, 70 , $380-384$

Probabilities, theory of, 205-206

Protection against fire part of the duty of the community, 127

Protection of trade the prime use of insurance, $18,33,383-384$

Public opinion, influence of, 80 , I 20, I72, 400-40I

Putnam, Kingman N., 45

Raber, Joseph, murder of, 344

Ransom insurance, 17, 23

Rates of marine insurance, causes of increase or decrease, 82

Reade, Charles, Foul Play, 43

Ritherdon, Edward, evidence on perils of navigation, 95

Royal Commissions, their nature and scope, 76 ; and labour and capital, 107; reports of, marine, 109, II4; child-life, 282-287; friendly societies, $3^{89}$

Russell, W. Clark, $A$ Salt Water Cure, 47

Seamen, and wages, law concerning, 78; lives endangered by over-insurance, 48

Shakespeare and insurance, 18

Shipbuilding, art of, injuriously affected by insurance abuses, $4^{8}$

"Ship-knacker," IOI

Ship-owners' Clubs, British, 78 
Smith, Jerome, case of (insurable interest), 329-330

Society, effect upon it of insurance abuses, 9, II, 46, 2 I I

State Commissioners of Insurance, quotations from, $32 \mathrm{I}-326,347$, 363-367

State control of insurance, 320 . See Free.

Statistics, danger of being misled by, $85,148,212$

Statutory conditions of policy, 62

Stevenson, Robert Louis, The EbbTide, 43

Storms, insurance against, 3I

Strange forms of insurance, 32

Tarbox, John N., Insurance Commissioner, Massachusetts, 353354

Tennyson's Maud, quotation from, 267

Thackeray, William Makepeace, quotations from, 305-306, 3 I9

The Ballad of the Bolivar, Kipling, 49, 50

The Ebb-Tide, Stevenson, 43

The Great Hoggarty Diamond, Thackeray, 305-306, 319

The History of Lloyd's. See Martin.

The Mary Gloster, Kipling, 4I-42

Theory of Probabilities, 205-206

Tonti, Lorenzo, "the father of life insurance," I90
Tornado insurance, $3 \mathrm{I}$

Trades unions and their insurance features, 29

Trustee of insurance fund, 6

"Underwriter," origin of the name, 64

Usury and its relation to insurance, 20

"Valued policy," marine, 79; laws concerning, fire, 140

Vessels lost at sea, number of, 9495

Viau-Parslow case, 229-233

Vital statistics, origin of modern system, 207

Wager policies, 52, 6I, 77. See Gambling.

Wages, insurance of, 28; seamen may not insure, 78

Wainewright, Thomas Griffiths, his crimes, 223-227

Walford, Cornelius, on antiquity of insurance, I 88

Walford's Insurance Cyclopedia, quotations from, marine, 56; fire, I29; child-life, 264

Wander, Tom (pseudonym), case of, 235

"West Middlesex" fraud, 3II-3I6

Windmüller, Louis, on "The Barnacles of Fire Insurance," I58I59

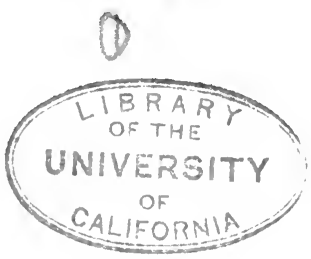





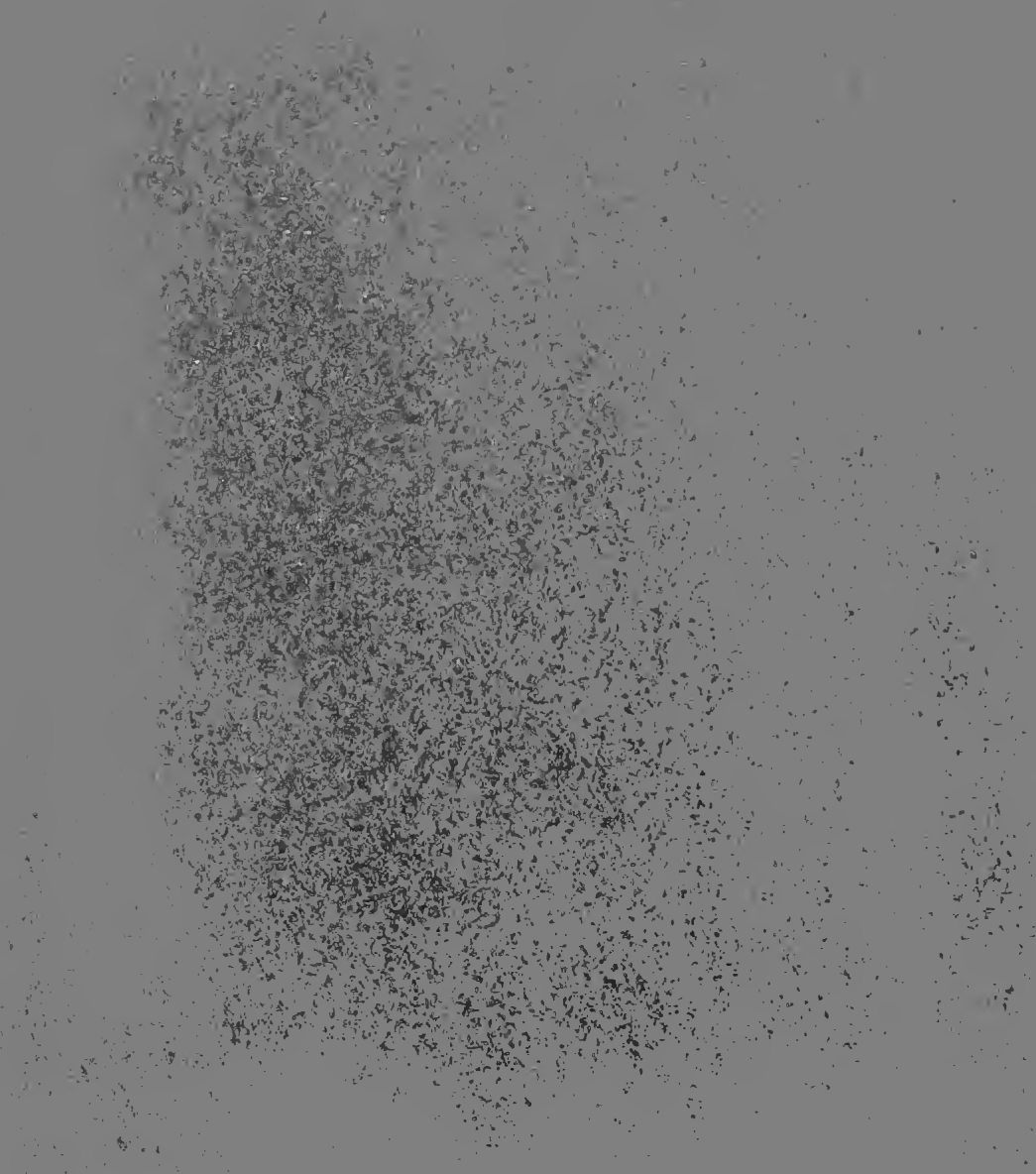

$\therefore$ $\therefore$

3

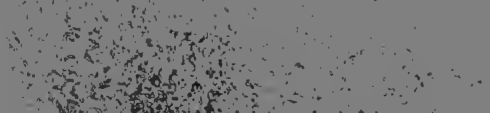

int

$30+4=0$

Skx

* on on a

$\therefore$ of 


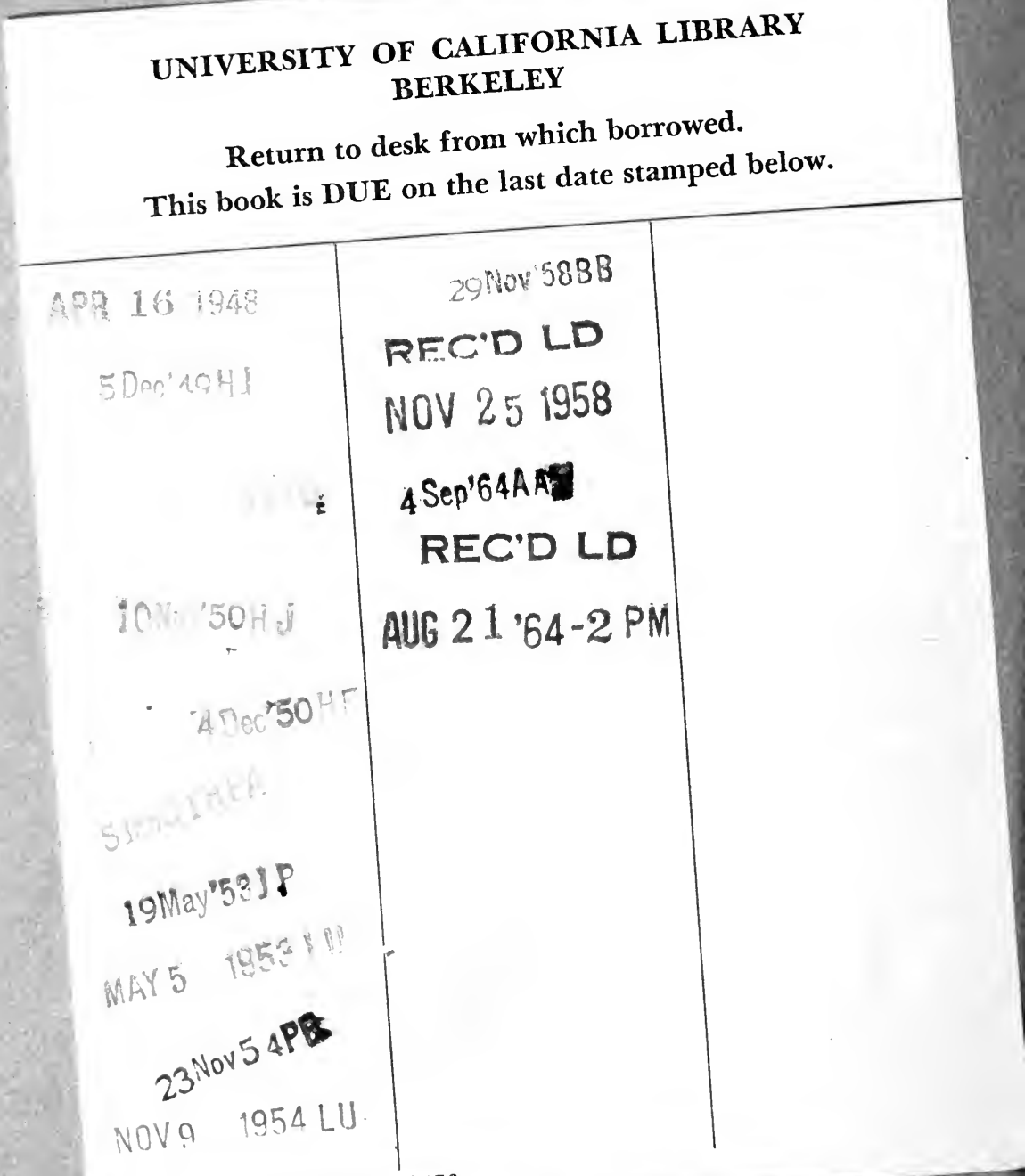


YC 23541

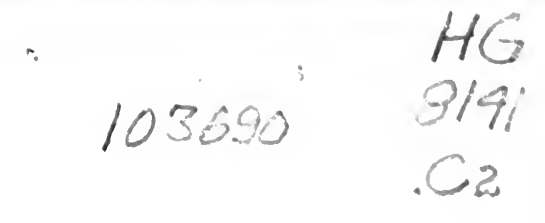

THE UNIVERSITY OF CALIFORNIA LIBRARY 
